
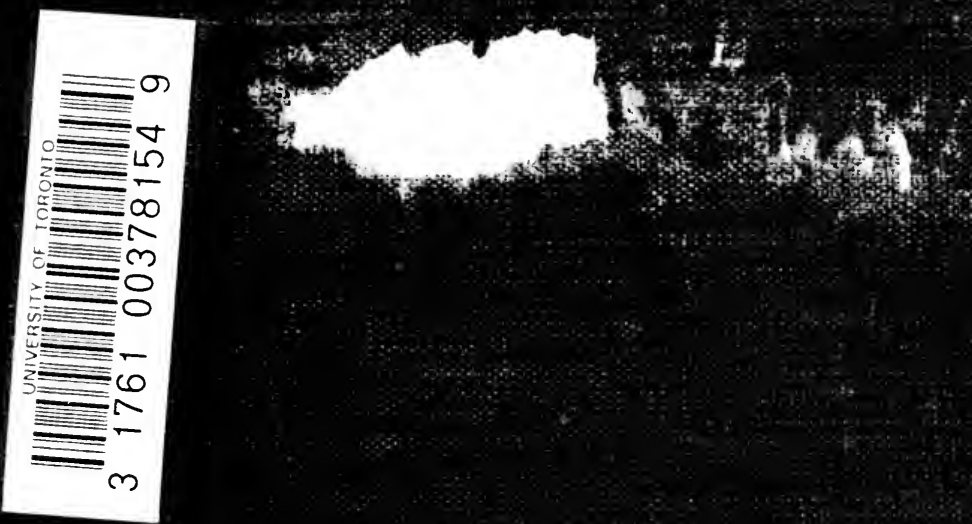

t 





\section{THE DEVELOPMENT OF WESTERN}

CIVILIZATION 


\section{Digitized by the Internet Archive in 2007 with funding from \\ Microsoft Corporation}




\section{THE DEVELOPMENT OF WESTERN CIVILIZATION}

A STUDY IN ETHICAL ECONOMIC AND POLITICAL EVOLUTION

By

J. DORSEY FORREST, Ph.D.

PROFESSOR OF SOCIOLOGY AND ECONOMICS IN BUTLER COLLEGE
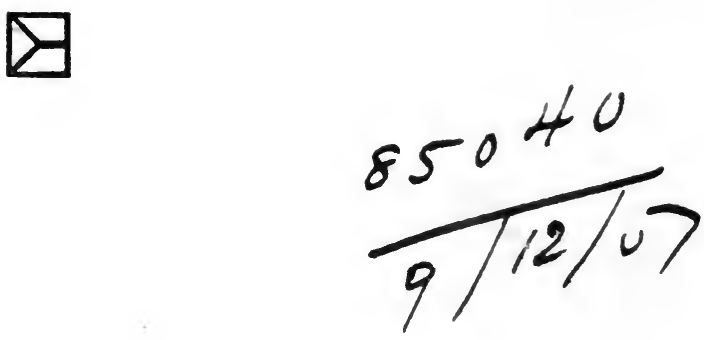

CHICAGO

THE UNIVERSITY OF CHICAGO PRESS

1907 


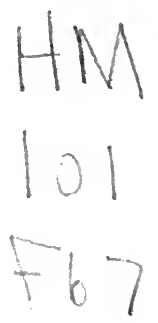

Copyright $1906 \mathrm{Bx}$

The University of Chucago

Published April 1907 
TO HER

FROM WHOSE TOO BRIEF COMPANIONSHIP

THE PREPARATION OF THESE PAGES

CUT OFF SO MANY PRECIOUS HOURS 


\section{PREFACE}

This essay represents the expansion of a dissertation offered for the degree of Ph.D. in the University of Chicago. It is the outgrowth of the study of certain present-day problems. Feeling the need of an explanation of the development of the conditions and institutions in which I was immediately interested, I was led backward step by step into an inquiry into social evolution in general. I have become convinced that a genetic explanation must underlie any other explanation. No fact can be understood until it is viewed in relation to the various other facts with which it is functionally connected; but all of these together are not adequately explained except in the light of their evolution. A sufficient statement of the method and purpose of this study is given in the introductory chapter.

To cover so vast a field in such a work as this the selection of materials for special examination becomes very difficult. I have not desired to rehearse the more common facts of history; but in tracing the general social movement, I have endeavored to account for the more important facts with which the histories deal. If slight reference is made to some important influence, as that of the Mohammedans, or to some striking activity, as that of the crusaders, it is simply because I think they are sufficiently accounted for in the general statement. Perhaps I should have made more direct application of my point of view to some of these important side movements. Minor counteracting forces and purely individual or local influences have not required treatment.

The footnotes contain reasonably full reference to authorities for facts and opinions. I have not thought it desirable to expand them further by citing authorities for statements of facts that have become common property. On the other hand, acknowledgment should be made to such pioneers in economic history as Rogers, Ashley, and Cunningham for assistance that is not 
confined to page and line of the text. My chief indebtedness, however, is to instructors under whom it was my privilege to work in the University of Chicago. I have made many references to the lectures of Professor John Dewey, now of Columbia University; but my obligation to him can by no means be sufficiently acknowledged in the footnotes. To Professor George H. Mead I am indebted for the important distinction between the intellectual and the emotional realization of social relations, and for the still more important conception of the character of the ideals which controlled mediæval society. I am unable to make specific acknowledgment for the many helpful suggestions made by him in his seminary in mediæval philosophy. I am still less able to make specific acknowledgment of my indebtedness to Professor Albion W. Small for the view of the nature of society and for the method of sociological investigation which have been the shaping influences throughout my investigations.

The pedagogical use which I have made of this material may not commend itself to other instructors; but it has increased my confidence in the value of the method which I have pursued. It has been my custom to follow a course in anthropology and culture history with a course in social history in which I have used substantially the material given in the following pages. Such courses have done more to enable students to apply the evolutionary point of view to the study of social problems than anything else that I have been able to give them:

Lest some readers may receive the impression that my view of society is materialistic, I desire to say that it is not. I am concerned here only with the problem of social evolution. The origin of the universe, the final destiny of the individual, the possibility of new light from a supranatural world, are problems which do not concern this inquiry. This last, at least, depends on a social development until some "fulness of time" is reached.

Both the preparation of the first draft of this work and its present revision have suffered many interruptions. As a consequence, my work has dragged on for several years; and this method of writing has doubtless caused some scrappiness in the presentation 
of matter which, under the most favorable circumstances, could with difficulty be given homogeneous treatment. This delay also accounts for failure to refer at all to some valuable books which have appeared recently; but I am familiar with none that would have changed the method here employed or the general results obtained.

INDIANAPOLIS, IND.

J. D. F. 



\section{CONTENTS}

CHAPTER

PAGE

I. The Contribution of Antiquity to Modern Society . . . I

The Contribution of Israel . . . . . . . . . . . 2

Religious Conceptions of the Tribal Period . . . . . . 3

Religious Conceptions of the National Period . . . . . 6

Influence of World-Movements on Religious Conceptions $\quad$ I3

The Culmination of Judaism . . . . . . . . . . 19

The Contribution of Greece . . . . . . . . . . 2 I

The Earlier Internal Development of Greece . . . . . 22

The Influence of Egypt and Phœnicia . . . . . . . 26

Period of Athenian Expansion . . . . . . . . . 35

Period of Decay and Reflection . . . . . . . . . 42

The Contribution of Rome . . . . . . . . . . 52

The Earlier Social Organization . . . . . . . . 52

The Expansion of Rome . . . . . . . . . . 56

The Development of Roman Law . . . . . . . 6 I

Summary . . . . . . . . . . . . . . . . 65

II. The Problem Set for Medifyal Society . . . . . . 68

Christian Doctrine and Polity to the Fall of Rome . . 69

The Beginnings of the Middle Ages . . . . . . . . 79

The Ethical Problem of the Middle Ages . . . . . . $9 \mathrm{I}$

III. The Organization of Agriculture . . . . . . . . . .

Roman Methods at the Trme of the Invasions . . . . ilo

Teutonic Agricultural Methods . . . . . . . . . II5

The Feudal System ANd Agriculture . . . . . . . i 20

Italy . . . . . . . . . . . . . . . . . . I23

England . . . . . . . . . . . . . . . 128

Western and Central Europe . . . . . . . . . . I54

Conclusion . . . . . . . . . . . . . . . I $8 \mathrm{I}$

fiV. The Development of Commerce . . . . . . . . . . 186

Preparation for Commerce. . . . . . . . . . . . I 90

The Beginning of Commerce . . . . . . . . . . . . 195

fThe Rise of the Towns . . . . . . . . . . . . . 200

Establishment of Urban Constitutions . . . . . . 207

The Gilds and the Status of the Individual . . . . . 219 
CHAPTER

The Southern Cities . . . . . . . . . . . . 237

The Cities of Southern France . . . . . . . . . . 237

Amalfi . . . . . . . . . . . . . . . 239

Venice . . . . . . . . . . . . . . . . . $24 \mathrm{I}$

Florence . . . . . . . . . . . . . . . . . . 245

The Decay of the Southern Cities . . . . . . . 248

The Commerctal Leagues . . . . . . . . . . . 257

The Natronal State . . . . . . . . . . . . . 274

X V. The End of the Mrddle Ages . . . . . . . . . . . 286

The Reformation IN ReLigion . . . . . . . . . 288

The Economics of the Church . . . . . . . . . 29r

The New Nominalism . . . . . . . . . . . . . 296

The Beginnings of Modern Thought . . . . . . . 298

Political Philosophy . . . . . . . . . . . . . . 302

The Conception of the State . . . . . . . . . . 303

The Law of Nations . . . . . . . . . . . . 305

The Democratic Movement . . . . . . . . . . 309

X VI. SOCIAL MOVEMENTS OF Today . . . . . . . . . . . . 3I 7

The Extension of Democracy . . . . . . . . . $32 \mathrm{I}$

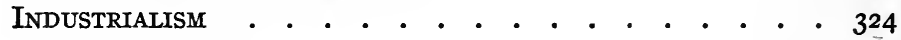

The Industrial Revolution . . . . . . . . . . 325

Capitalism . . . . . . . . . . . . . . $33 \mathrm{I}$

Labor . . . . . . . . . . . . . . . . 339

Consumption . . . . . . . . . . . . . . . . 350

Socral Ideals

Appendix: Method and Scope of Inquiry . . . . . . . . 365

The Relation of Fact to Interpretation . . . . . . . 365

The Complexity of Social Phenomena . . . . . . . . 368

The Interrelations of the Various Social Sciences . . . . 37 I

The Organic Nature of Society . . . . . . . . . . 373

The Genetic Study of Society . . . . . . . . 376

The Demands of Sociology upon History . . . . . . 384

The Method and Material of Social History . . . . . . 387

The Relation of History of Thought to Social History . . 393

INDEX . . . . . . . . . . . . . . . . 398 


\section{CHAPTER I}

\section{THE CONTRIBUTION OF ANTIQUITY TO MODERN SOCIETY}

Social history $^{x}$ is more than a mere description of customs, manners, and unfamiliar incidents which have been omitted by the ordinary historians. It is an account of the most significant events in the life of a people-of events which have had a shaping influence in the development of their social organization as a whole. It must traverse much of the same ground covered by the ordinary histories; but it will view the same facts from a different angle, and must introduce many facts which are disregarded by the historian of political events. But a social history must do more than relate facts. If the course of social evolution is to be traced, it is necessary to analyze the facts in order to discover their causal relations; and this analysis must be as much broader than that of ordinary historical method as the whole social life is broader than the political institutions of society.

In the following pages the analysis of the significant facts of European social history is made on the basis of their ethical, economic, or political values. ${ }^{2}$ When viewing social development in its ethical aspects, the significant fact for us is the end or ideal of society. We shall find that the social activities are largely shaped by the social ends. At the present day these are varying and uncertain, and are projected by the very activities which must be guided by them; but during the formative period in European social development they were definite and fixed, and had been given by forces outside of the existing society.] They were the result of the development and decay of previous societies. It is therefore necessary to trace the development of the essential features of certain ancient societies, and to discover the manner in which these were transmuted into ideals for Europe. There is

IVide Appendix.

2 Vide Appendix. 
nothing new in the statement that modern society has inherited much from the past; but the fact that this inheritance was in the shape of ideals which guided the activities of Europe for a thousand years is not so commonly recognized. We must first trace the working-out of these ideals by antiquity.

Modern civilization is the result of the appropriation by Teutonic peoples and other peoples with whom the Teutons had mingled of the outcome of the Israelitish, the Greek, and the Roman social life. Each of these societies had perished as it came to consciousness of the essential nature of its own life. The translation of its social activities into consciousness came about when the national life was disintegrating and men were forced to reflect upon it.] The three strains were blended in the GræcoRoman Empire, and were carried over to modern society, represented chiefly by the Teutons, largely through the instrumentality of the church. The beginnings of modern society are to be found in these three ancient societies rather than in the earlier life of the Teutonic tribes themselves; for the latter contributed little more than the raw materials of civilization. They furnished the practical strength with which to appropriate the contributions which the other peoples had exhausted themselves in making. Accordingly, a study of the evolution of modern society involves a consideration of the heritage from antiquity with which the barbarians started off.

\section{THE CONTRIBUTION OF ISRAEL}

The history of the Israelites is the history of the development of a nomadic people under peculiar conditions. The wandering life of the Hebrew tribes did not permit the development of local divinities, and was therefore unfavorable to the development of polytheism. The Hebrew monotheism, however, was but the absence of multiplicity, the reflection of a simple mode of life; it had not the significance of the Greek monotheism which arose from the formulation of a single law and order in a universe that was full of multiplicity. ${ }^{\mathbf{x}}$ Only in later times does the monotheism of Israel assume the same characteristics as the Greek; but it is none the

r Dewey, unpublished lectures on The Evolution of Morality. 
less effective-indeed, it is more effective-as a social force because it is of this naive character.

The religious life of the Semitic tribes probably differed but little from that of the Aryans when the social organization and mode of life of the two groups were similar. The divergence of the religious development of the two races, which became more and more marked in the course of ages, was not caused altogether, or chiefly, by innate racial tendencies, but was due to the operation of local and historical causes. If the Aryans had gone through the same tribal experiences as the Semites at as early a period, they would probably have manifested the same religious characteristics, though certain racial traits may have been developed while each was in the savage state. The small Semitic communities were separated from each other by incessant feuds, necessitated largely by their physical environment; hence the strengthening of the patriarchal principle and of the principle of solidarity between gods and their worshipers could go on as nowhere else. ${ }^{x}$

Religious conceptions of the tribal period.-Neither the social life nor the religious conceptions of the Hebrew tribes appears to have differed materially from other Semitic tribes; but as time went on certain of the common tendencies received a peculiar emphasis and certain new tendencies began to appear; and this peculiar development, especially in later times, became more marked in the case of the Israelites than in that of the other Hebrews.

The economic conditions of Hebrew life, alike removed from the hunting and the agricultural stages, prepared the way for the development of a monotheism. The patriarchal family was strongly organized. Under pastoral conditions flocks and herds become private property, and a constant accumulation and transmission of property goes on. In savage life there is no such thing as private property. ${ }^{2}$ Hereditary chieftainships grow up with hereditary continuance of property. Persons who have been un-

I Smith (W. R.), The Religion of the Semites, 32-35.

2 Dr. Veblen has suggested the term "quasi-personal fringe" to describe the few personal possessions which are found in savagery. 
successsful in building up strong families and securing great wealth fall under control of the powerful chief either by conquest or by voluntary surrender. The powerful individual thus stands out from the mass, and the basis is found for both the development of social organization and the spreading of the sense of individuality throughout the mass. The consciousness of individuality is a comparatively late social product. A few individuals had to be raised above the mass; then others could follow them. ${ }^{x}$ The consequence of this emphasis of the personality of the patriarch or chief is, first of all, the recognition by the masses of the individual rights and powers of the chief and of the god who is the counterpart of the chief; only much later do the masses come to recognize the rights of all individuals.

Thus, the economic conditions of the Hebrews made necessary both the consolidation of the family and the growth of individuality. The gods of the Hebrew tribes, in common with those of peoples in a similar condition, naturally became members of the social group-fathers or chiefs, or both-and the rites and ceremonies were those which belonged to the community. The social opposition was not between the people and its gods, but between peoples, including their gods. Other gods were not denied, but their character was regarded as inferior. The religion of the Israelites was thus monolatrous rather than monotheistic. There was nothing inconsistent in their wandering after the gods of their kinsmen, when these seemed for the time able to grant them favors. But since every small Semitic community was frequently on terms of hostility with all neighboring tribes, the development of a polytheistic system was practically impossible. $^{2}$ When Israel was at war with neighboring tribes, Israel was most faithful to Jehovah.

It was only as the smaller groups coalesced into larger ones that a pantheon could be formed on the model of the more complex social organization. The problem of the Assyrian and Babylonian leaders was the formation of a larger society which

I Dewey, ibid.

2 Smith, op. cit., 35-39. 
would include numerous smaller groups and their gods. The earliest religious conceptions had been lost long before the period at which we first find the Aryans and Semites; but from the earliest formation of the Semitic pastoral groups, each worshiped in its own small clan a tutelary divinity who was protector of the flocks and herds. This was characteristic of all Semites during their tribal life, and had its influence in the later religious development of all of them. ${ }^{x}$ But at a very early period the usual religious development, and the amalgamation of neighboring tribes introduced polytheistic tendencies; and the persistence and development of the monolatry of the Israelites must have been due to peculiar influences. The vague, primitive worship of the one protector of flocks, becoming more definite and anthropomorphic with the development of their social organization, led the other Hebrew tribes-the Edomites, Moabites, and Ammonites-to a polytheistic religion; but the Israelites were saved from a similar course. Their difficulty came later when they fell under the influence of the civilized Canaanites whom they had conquered, or when they were influenced by foreign alliances; and then the seductions of foreign practices could not lead to an amalgamation that would give their national religion a genuinely new trend. Why the Israelites did not become polytheists, it will probably never be possible to tell with certainty. The close relationship of the clans, their long semi-subject position on the edge of the Nile valley, the commanding influence of Moses, the exigencies of their migrations, all contributed to maintain their earlier religious customs until the latter had become too fully developed to be easily altered. ${ }^{2}$ At all events, when the Israelites entered Palestine, although they were at a low level of civilization, they

Pietschmann, Geschichte der Phönizier, I 70.

2 Montefiore, Origin and Growth of Religion as Illustrated by the Religion of the Ancient Hebrews, 29-50, explains the unique character of the Israelitish religion wholly on the basis of the genius and power of Moses. But the "law of monolatry" of which he makes so much would be inexplicable except on the assumption that it was not wholly at variance with a previous "custom of monolatry." Moses could have had great influence at some critical time in shaping the religion of his people; but he could hardly have been able to make it over. 
had an enthusiasm for the religion of Jehovah which enabled them to absorb the more highly civilized Canaanites, in spite of the temptations of a more sensuous worship, held them together in more or less unity, in spite of local jealousies and the enforced isolation that resulted from simultaneous attacks in every section; and finally, when they were consolidated under pressure of a single enemy, made it possible for them to blend the different local divergencies of religion into a common national faith and worship. The remnants of family totems or household gods ${ }^{\mathbf{I}}$ did not entirely disappear until a late period, and the temptations to turn to the grosser forms of worship of neighboring peoples were strong until after the exile; yet the Israelitish religion had a most decided monotheistic tendency from the beginning of the national history.

Religious conceptions of the national period.-It is impossible within the limits of this chapter to discuss in detail the nature of Israel's religious development; but the statement above made will be sufficient for our present purpose. Until the monarchy was well established, the conception of God as a father and chief remained practically unchanged. Since the break-up of the narrower tribal life, God could not be so much a father as a chief, but the idea of inclusion of God within the community still prevailed. The change that went on during the later tribal period and the earlier national period was the counterpart of the social change. The natural religious relationship of child to father changed to the covenant relationship, and God came to be regarded as a king; but the people were not set off over against God in their religious conceptions until after the beginning of the influence of world-movements upon the life of Israel.

The covenant relationship grew out of the practice of isolated men putting themselves under the protection of powerful chieftains. From the earliest times the lawlessness of the desert has been tempered by the practice of hospitality for a few days, and more permanent protection is usually granted when desired. Under these latter circumstances, the strangers, gerim, as the Semites called them, would naturally be absorbed into the clan.

I Gen. 31: I9 ff.; Judg. 17:5; I Sam. 19:13; Hos. 3:4. 
But when they became very numerous because of the migrations and the deportations of conquered peoples, the newcomers became clients rather than children of the chief and tribal god. A man was no longer so sure of his standing with the tribal god as he had formerly been, but felt that his acceptance depended on his good behavior and the free grace of the deity. The ceremony connected with naturalization was thus transferred to the relationships of the client to the patron god, and there was practically a covenant established by which certain favors were received in return for certain sacrifices and ceremonies. ${ }^{x}$ It was, of course, natural that the important ceremony of naturalization should be consecrated by religious ceremonies at a time when all of the essential functions of life were so consecrated, and it was equally natural that such a social arrangement should be reflected in the religious conceptions of the time. With the amalgamations and subjugations which accompanied the formation of larger communities, the covenant idea came to replace the older conception.

What the social causes of the universal acceptance of the covenant idea by the Israelites were we do not know. Possibly a number of clans not previously united were forced to associate together, and as a sign of their amalgamation formally adopted the divinity of the most powerful. ${ }^{2}$ Possibly Moses had been able to secure the general recognition of the deity of his own family or clan. ${ }^{3}$ Possibly the necessary amalgamation of the tribes during the migrations had brought it about. But although the covenant idea was held at the beginning of authentic history, its full force did not come out until after the exile, when the last remnant of the old natural relationship to God had disappeared and the people felt that they had no rights of their own, but were absolutely dependent on the bounty of Jehovah. ${ }^{4}$ By that time the conception of a physical relationship to God as a necessary father had disappeared, and the relation became a voluntary one based on an agreement which implied two parties.

I Smith, op. cit., 75-8r.

2 Dewey, ibid.

3 Wellhausen, History of Israel, 433.

4 Lev. 25:23; Ps. 39:12; I Chron. 29:15; etc. 
Along with this development of the covenant idea, there had gone another change with the Israelites in common with some of their Semitic neighbors. God, from being a father like the patriarch, became an absolute king. This idea also was the reflection of the social conditions. It came about by the decay of free tribal institutions, when some members of the tribes had become strong enough to retain the chieftainship in their own family. The law of blood-revenge was then moderated, the object of the chief being to preserve and strengthen his tribe by reconciling disputants. As the chief became stronger and better able to enforce his will in settling his subjects' quarrels, it became natural to think of the deity as the champion of right against might. The primitive equality of the tribal system thus passed into an aristocracy of the more powerful leaders, and the poorer members dropped into a dependent position. The king or head chief alone could check the aggrandizement of the nobles, and he always sought to do so in order to maintain his own authority. In Greece and Rome and among the Teutons the kingship fell before the aristocracy; in Asia the royal power usually held its own. It had to be so, if the nation was to survive in the midst of powerful neighbors, while the isolation of small groups of the Aryans in the earlier period enabled them to maintain an aristocracy. The Asiatic king devloped into a despot, or was crushed by a neighboring despot. This social condition was reflected in the religious conceptions.

The tendency of the West, where the kingship succumbed, was toward a divine aristocracy of many gods, only modified by a weak reminiscence of the old kingship in the not very effective sovereignty of Zeus, while in the East the national god tended to acquire a really monarchic sway. What is often described as the natural tendency of Semitic religion toward ethical monotheism, is in the main nothing more than a consequence of the alliance of religion with monarchy. .... The prophetic idea that Jehovah will vindicate the right even in the destruction of his own people of Israel, involves an ethical standard as foreign to Semitic as to Aryan tradition. Thus, as regards their ethical tendency, the differences between Eastern and Western religion is one of degree rather than of principle; all that we can say is that the East was better prepared to receive the idea of a god of absolute righteousness, because its political institutions and history, and, not least, the enormous 
gulf between the ideal and the reality of human sovereignty, directed men's minds to appreciate the need of righteousness more strongly, and accustomed them to look to a power of monarchic character as its necessary source. ${ }^{\mathrm{x}}$

Hence, the Aryan pantheons in Europe were oligarchical; those of the Semitic nations and of their Aryan neighbors who lived under similar conditions were despotic. From the subjugation of all rivals by the king, the inference was naturally drawn that there was one supreme god to whom all men and all other gods were subject. If a pantheon was not formed, the supremacy of the divine king over men was none the less marked.

As a result of these two important conceptions-God as an absolute sovereign, and man's covenant relationship to him-certain changes took place in the mode of worship; and these changes were furthered by the change in industrial life. Sacrifice among the Semites had at first been chiefly the sharing of the common meal with the god who was a member of the community. Animal sacrifice belongs distinctively to the pastoral stage of social life. The sanctification of the common meal, which is impossible among a hunting people whose meals are very irregular, implies the solidarity of the family and the inclusion of the gods within it. Therefore every patriarch was a priest. This condition of affairs lasted until the convenant idea had become universal. So the earliest Israelitish code of law, the Book of the Covenant, which was applicable in an early agricultural stage of civilization before nomadic habits had entirely disappeared, makes no reference to the interposition of priests in the customary sacrifices. ${ }^{2}$ These laws give evidence of the covenant conception, ${ }^{3}$ but the local forms of worship had not been displaced by the national cult. This, code was doubtless the law of the land from the end of the period of settlement until the monarchy was permanently established. The priestly class was doubtless in existence during a part of that period, but was only of local importance. It was impossible, after the dispersion of the clans over the conquered territory,

Smith, op. cit., 73, 74 .

2 Exod. 20:22-23:33.

3 Driver, Introduction to the Literature of the Old Testament, 35. 
to maintain the central political and religious system that had been rendered necessary by the exigencies of the wilderness march and the common wars of the migration. The Mosaic sanctuary soon lost its central importance and became a local shrine. ${ }^{\mathbf{x}}$ The religion of the supreme Jehovah was not necessarily discarded, but the local forms of worship, influenced by contact with Canaanitish practices, became of much greater relative importance. Only in times of common danger could the people be united politically or religiously.

But the development of agriculture, the increased facility of intercommunication, and the centralization of political power necesarily led to the centralization of the national elements in the religion. That this did not take place at once, even with the building of the temple, is shown by the continued prevalence of local forms of worship. The central worship could not crowd out at once the local practices. The earlier prophets, Elijah and Elisha, although speaking for Jehovah, took no exception to the calf-worship of the northern kingdom. What these men contended for was the customary morality of Israel as against the contamination of foreign practices. The narratives of these two prophets incorporated in the book of Kings know nothing of the law of the single altar, and accept as fitting a semi-patriarchal form of worship. By their time the sacrifices had lost something of their old honorific character and had taken on something of the character of tribute rendered to the deity in order to receive his favors, but they had not yet become distinctively expiative.

As a consequence of the changes that were going on in the religious life of the people, a conflict arose between those who stood for the older practices and those who stood for national centralization. The former were the prophets, the latter the priests. Biblical scholars usually recognize a conflict between these two parties, but make practically no distinction between this earlier conflict and that which was carried on after the period of written prophecy began. In this latter conflict the prophets appear as the liberals and reformers; and it has been concluded that the

× Smith (W. R.), The Prophets of Israel, 36-38. 
prophets always represented the progressive element. But the only common characteristic of the prophets of the two periods was their common opposition to the royal power in the interest of the morality of the people.

The earlier conflict seems to have been carried on by the prophets in the interest of the customary rights of the people which were being endangered by the centralization of religion at the capital and the importation of foreign practices. There had been no particular opposition to the establishment of the royal power, for all classes felt the need of a stronger political organization, while the agricultural development rendered such an organization possible and natural. Men did not see that such political changes were bound to lead to religious changes. The prophets did not oppose any of the various local forms of worship, even when these were connected with a mild form of idolatry; but they did object to the destruction of local rights in the interest of the central government and to the importation of foreign customs which the national politics rendered necessary. Nathan was able to deter David from building the temple, ${ }^{\mathbf{I}}$ and thus prevented him from centralizing the religious interests as he had centralized the political. Nevertheless, the centralization was bound to come; and under Solomon an extensive religious establishment was set up. Yet this did not do away with the local religious practices, and there was no serious attempt to root these out until well on toward the time of the exile. When, however, Solomon introduced foreign religious ceremonies-which seem to have been uniformly acceptable to the priests-it was felt that the foundations of Israelitish religion were being sapped. And when Solomon added to these errors the voluptuousness of an oriental court, and the eco-' nomic follies by which he impoverished all the other sections to adorn his capital and exchanged the scant agricultural products of Israel for monkeys, peacocks, ivory, and other luxuries, ${ }^{2}$ the prophetic class which stood for the traditional morality rebelled and inspired the division of the kingdom.

III Sam. 7:1-I7.

2 McCurdy, History, Prophecy, and the Monuments, II, $\mathrm{I}_{55}, \mathrm{I}_{5} 6$. 
Yet the idea of a national religion gradually gained favor, and even the northern rulers felt constrained to follow the example of Judah. With the development of the political machinery at Jerusalem, the supremacy of the priests in the southern kingdom was assured. The prophets were the dominant power in the northern kingdom; but as local institutions steadily degenerated, they either degenerated with them or began to look to the sacerdotal establishment at Jerusalem as the highest ideal for the whole people. By the time of the first written prophecies, the work of the regular prophets had sunk to a mere trade, ${ }^{x}$ and Hosea regarded them as so corrupt that he included prophets and priests in a common condemnation. ${ }^{2}$ The moral sense of the nation was being debased when these new prophets arose and condemned both classes of official religious leaders. ${ }^{3}$ Neither Amos nor Hosea shows familiarity with the Deuteronomic code, but both are representatives of the movement which finds expression in that code. It was found that the separation of Israel from heathen practices and the preservation of the national morality demanded something analogous to the law of the central sanctuary of Deuteronomy.

History had shown that it was impossible to secure the local sanctuaries against abuse, and to free them from contamination by Canaanitish idolatry. The prophets had more and more distinctly taught that Zion was emphatically Jehovah's seat; and it became gradually more and more plain that the progress of spiritual religion demanded the unconditional abolition of the local shrines. It was not enough to demolish heathen sanctuaries: other sanctuaries, even though erected ostensibly for the worship of Jehovah, must not be allowed to take their place. Hezekiah, supported, it may be presumed; by prophetical authority, sought to give practical effect to this teaching. But he was unable to bring it really home to the nation's heart; and the heathen reaction under Manasseh ensued. Naturally, this result only impressed the prophetical party more strongly with the importance of the principle which Hezekiah had sought to enforce; and it is accordingly codified and energetically inculcated in Deuteronomy.4

I Amos 7:12.

2 Hos. 4:5.

3 Smith, Prophets, I04, I05.

4 Driver, Introduction, 93. 
This body of legislation, first enforced by Josiah in 62I, marks the social recognition of the necessity of a centralized religion. The ends desired were not fully secured until after the exile, but the ideal was definitely recognized. Without this the nation would probably have disintegrated when assaulted by its powerful foes. The effect of this movement would seem to be simply to strengthen the priests; but it also helped to secure the results desired by the prophets. The ordinary man, outside of Jerusalem at least, could no longer find the essence of religion in liturgical acts. He was now in a position to be kept in the line of moral activity which the prophets enjoined. ${ }^{x}$

Influence of world movements on religious conceptions.-The national religious development culminated with the centralization of worship. This was rendered inevitable by the unification of the nation following the development of agriculture and expressing itself in the establishment of the monarchy. The efforts of the earlier prophets to withstand this movement were ineffectual, though they doubtless prevented the nation from absorbing debasing elements from the religions of their of more highly civilized neighbors. But this centralizing movement did not culminate until Israel began to feel the effect of the growth of world empires. These larger political movements accelerated the developments we have just traced, and would have been ruinous but for the latter; yet the development under the influence of these world movements was what made Israel's contribution of value to the world.

The real essence of the prophetic movement appears with the beginning of the world movements of the eighth century в. c. It was then that world history as distinct from local history began. Before this, local institutions and beliefs could run their course with little interference from other nations. Now, they had to be generalized to meet the new situation. This was true even of those institutions that were backed up by sufficient national force to enable them to absorb other local institutions and beliefs. Much more, then, was it true of those which had to persist by

Xellhausen, History, 468. 
virtue of their inner worth. The universal empires threatened to absorb the Israelites. It was no longer possible to cleave to Jehovah, allowing all other peoples to cleave to their national gods. It seemed that there could no longer be more than one god, for it seemed that that there could no longer be more than one nation. To accept the Assyrian divinities, as other conquered peoples did, was now out of the question. But how was their belief that Jehovah was the only God to be reconciled with the fact of their imminent national danger? With this break in the social habits, there came a consciousness of a dualism: the offended deity was set off on one side and the sinful nation on the other. ${ }^{x}$ God was no longer a member of the Israelitish community. The last vestige of the old natural relationship of the people to God had passed away.

The most thoughtful men of the nation immediately began to look for the cause of the evil. Their first conclusion was that the cause was to be found in the toleration of foreign religious practices. These were now seen to be an unmixed evil, since they offended Jehovah without securing efficient help from the nations with which the sinful alliances had been made. The efforts to solve the problem took two courses. Both emphasized the need of unity; but one would secure it by purifying and restoring the old religious customs, while the other would cut loose from all ceremonies and find reunion with God by developing the right disposition. The former was the remedy proposed by the priests, the latter by the prophets. Here, as in the earlier period, the two classes arose simultaneously, both representing the succession of the old patriarchal priests.

The sacerdotal movement sought to maintain the old order, but had to put a new meaning into it. The sacrifices should be kept up, but the deity could no longer be considered a member of the community. He no longer received honorific offerings as a father, nor tributary offerings as the covenant ruler; he had become an angry being, to be appeased by expiative sacrifices. The consciousness of guilt came with trouble and defeat, and God was no longer identified with the interests of his people. The

× Dewey, ibid. 
sacrifices became a magical means of restoring the broken religious unity. The central religious authorities had been greatly strengthened by the Deuteronomic movement, but after the exile they became the ruling aristocracy of the nation. In Deuteronomy the priest appears simply as the regulator of the sacrifices; in Leviticus he is a mediator. In the former code the sacrificed ani$\mathrm{mal}$ is to be eaten by the owner in the sanctuary, ${ }^{\mathbf{x}}$ in the priestly code it is assigned to the priest for his absolute use. ${ }^{2}$ In the earlier code it is implied that all Levites are qualified to exercise priestly functions and that they have no settled residence; ${ }^{3}$ in the later the priests are differentiated from the other members of their tribe and regular places of residence are prescribed. ${ }^{4}$ In short, the democratic element of the old religion had entirely disappeared, and the sacerdotal class had become necessary to bridge the gulf between the people and God. Set ceremonials took the place of the popular religious customs. The old forms were gathered up and worked into the national cult, so that they might be preserved. God could be appeased only through the priests. This movement began with the threatened downfall of independence, and soon showed its essential character, but it did not gain full force until the time of the reforms of Ezra (444 B. C.) after the return from exile. ${ }^{5}$

At the same time that the priestly class was receiving this development, the more interesting prophetic class also arose to great importance. The prophets would preserve the popular customs, in so far as possible, and would keep Jehovah in close relations with the entire life of his people. They regarded the external forms of which the priests made so much as simply external and indifferent. The prophets first hoped that the reformation of their nation would secure the favor of God and turn back the invaders. The invaders were simply chastisers sent by God

× Deut. 12:6, 7, 17-19; 15:19, 20.

2 Numb. $18: 18$.

3 Deut. 18:1, 6, 7, 8; 12:12, I8, I9, etc.

4 For a full statement of differences, vide Driver, op. cit., $82 \mathrm{ff}$.

5 For a full discussion of Semitic sacrifice and the changes through which it passed, vide Smith, Religion of the Semites, 2 I $2 \mathrm{ff}$. 
upon the unrighteous nation. The ancient belief in the unity of the divine will with the political interests of the nation could no longer be entertained by the prophets. The sinners had to be destroyed before Jehovah could restore the nation to his favor. No assistance could be given to the guilty rulers who had been chiefly instrumental in bringing the calamities upon the land. Amos and Hosea, and Isaiah in his earlier prophecies, were confident that the sinners could be punished, that the good could be sifted from the bad when the chastiser should come. ${ }^{x}$ But after Ephraim was carried into captivity by the victorious Assyrians, Isaiah began to see that the good could not be sifted from the bad, should the whole nation be carried off. He therefore took the position that the state of Judah and the house of David could not be utterly overthrown. He became a statesman, and helped to turn away the danger.

But Isaiah did more. He formed a strong prophetic party to keep alive the true faith and become the remnant which should save the people. The national religion could not have been preserved, had it then been uprooted from Palestine; Judah would have gone the way of Israel. But this community of the true faith, freed from dependence upon the priestly ceremonies, would be able to hold together anywhere. The traditions could be handed down, supplemented by the sacred literature of which the beginnings had been made; and so the people could become more truly the worshipers of Jevovah in Babylon than they had ever been at home. Finally, Jeremiah was convinced that the temporary destruction of the nation was not only inevitable but desirable. He saw that the faith of Jehovah could then survive exile, being handed down from father to son in the Babylonian dispersion in a way that would have been impossible in the Assyrian period when the northern Israelites were deported. ${ }^{2}$

The prophetic movement had thus come to the position that the ethical life could find expression and the worship of God be maintained under any political conditions whatever. The

I Von Orelli, Old Testament Prophecy, 224, 231, 232; Smith, Prophets, 254-57.

${ }^{2}$ Smith, Prophets, 256-64. 
strength of the movement consisted in this freeing of the ethical impulse. ${ }^{\mathrm{x}}$ Individual righteousness thus became possible as never before in the history of the world. Jeremiah acknowledged that the men of his day were unable to shake off the bondage to religious solidarity; but he was led to reflect as much upon his own as upon Israel's relations to Jehovah, and could look forward to the time when each should be brought into individual relations with the deity. ${ }^{2}$ Jehovah would make a new covenant with Israel, under which, without interposition of priest or prophet, all should start afresh with a knowledge of God. ${ }^{3}$ This conception of the possibility of untrammeled worship was the peculiar contribution of the prophets, and saved Judah from utter disintegration during the dispersion.

We have seen that the prophets and priests were practically united in the Deuteronomic period and that, while the prophets evidently inspired the Deuteronomic code, the priests found it to their interest to enforce it as far as possible. ${ }^{4}$ Although the priests laid the emphasis on correct ceremonial worship, while the prophets emphasized the importance of a right disposition, the best elements of both classes, the men who were really trying to solve the problem of the shattered social consciousness, seem to have worked in pretty close unison until the exile. ${ }^{5}$ When that disaster befell Judah, all the more serious men had become thoroughly monotheistic. While, however, some found relatively little difficulty in preserving their faith in Jehovah in a foreign land, others found it very. difficult to understand how Jehovah, who, they had been taught, could be approached only at Zion, could now be worshiped in Babylon, especially after the temple at Jerusalem was destroyed. The task of keeping the people true to Jehovah then fell chiefly to the priests. The fall of Jeru-

$\therefore$ Dewey, ibid.

2 Jer. 3 r : 29 ff.

3 Montefiore, Religion of the Ancient Hebrews, 217-21.

4 Uriah, chief priest under Hezekiah, was a close friend of Isaiah; Jeremiah himself belonged to the preistly class; Hilkiah, chief priest under Josiah, first sought to enforce the Deuteronomic code.

5 Montefiore, op. cit., $175 \mathrm{ff}$. 
salem had been the triumph of prophecy, and the promises of a continuity of faith were the chief consolation of the people in exile. But the priests had to organize the faith of the people and prepare them for the return; and during the centuries succeeding the exile, the priestly element was usually needed to hold the people together. While hoping for the restoration of the regular worship, the true believers had to learn how to maintain their religious separateness without an elaborate ceremonial. Such rites as were not dependent upon the temple received a new development. Circumcision, which had been a custom without particular connection with the worship of Jehovah, came to be regarded as a divine ordinance distinguishing the faithful from all other races. Prayer came to supply the place of sacrifice. The prophetic and the priestly elements were blended in Ezekiel, but the outcome of the exilic experience was a development of belief in the importance of regular worship. Both by the increased emphasis on the right worship in so far as it could be carried out, and by the development of the law of ceremonial cleanness, a growing importance came to be given to the priestly element in spite of, or rather because of, the absence of the actual temple worship. ${ }^{x}$

The reason of the failure of the prophetic movement was its inability to provide means for the objectification of the universal principle which it stated. It could state the essence of monotheism and the supreme importance of the ethical impulse, but it could give no working formula for the guidance of life. It rightly demanded that the ethical impulse should be freed from the conventional expression which belonged to an earlier age, but it could not tell to what the ethical impulse was to lead after it was freed. The movement succeeded admirably in demolishing a great deal of accumulated religious rubbish, but it showed no constructive power. Because of this failure the priestly element had to be given control. The prophets had said that, since the old social habits could no longer function, the unification of consciousness was to be found in the harmony of the ethical impulse with the will of Jehovah. To this the priests replied,

Montefiore, op. cit., $229 \mathrm{ff}$. 
that the satisfaction could be found in the continuation of the old religious habits. ${ }^{x}$ Something of the ritual could be maintained under any form of political control. If all the details of the old service were not possible, they could go so far as possible and wait for the time when all could be restored.

Of course, this position amounted to a reconstruction of the old habits. The priestly position was really taken under the influence of the prophetic movement. It was a compromise which united pure and absolute monotheism with the intense particularism that characterized the later Jews. The result was the formation of a church. A special institution was needed to hold the people together under any form of government, while the priestly position implied a unity of the whole social life with the will of Jehovah. The continuity of the social life was thus found, not in the old social activities, but in the maintenance of peculiar relations with God. This was the development of the little company gathered together by Isaiah, the remnant that should be saved.

The formation of this little community was a new thing in the history of religion. Till then no one had dreamed of a fellowship of faith dissociated from all national forms. . . . . It was the birth of a new era in the Old Testament religion, for it was the birth of the conception of the church, the first step in the emancipation of spiritual religion from the forms of political lifea step not less significant that all its consequences were not seen till centuries had passed away. The community of true religion and the political commun. ity of Israel had never before been separated even in thought; now they stood side by side, conscious of their mutual antagonism, and never again to fall back into their old identity. ${ }^{2}$

This was the first appearance of a religious community apart from the activities of domestic and national life. Israel thus became a monotheistic church which could maintain its existence more or less completely under any external conditions whatsoever. ${ }^{3}$

The culmination of Judaism.-By the development just traced the monotheistic conception was deepened: a single unified principle was asserted-the unity of all life in relation with God.

$\therefore$ Dewey, ibid.

2 Smith, Prophets, 274, 275.

3 Cf. Smith (G. A.), The Book of Isaiah, I, I19-30. 
But God was conceived as manifesting himself only in a particular way to the chosen people. Jehovah had been universalized, but this could be known only to the people of the old national Jehovah. There was an irreconcilable contradiction between the universal monotheism, on the one hand, and the single religious community with its particular ceremonial, on the other. This contradiction was felt; and it was held that the ceremonial religion was only protective of the real values Israel had attained, until God should more fully manifest himself. The monotheistic idea could not be freed from its old embodiment, because it was built up on the basis of the old popular religion. If the development had culminated in the conception of the one God, instead of the one Jehovah, there might have been a monotheistic philosophy as in Greece, but there could not have been a monotheistic religion. ${ }^{x}$

The contradiction between the universal principle and its particular expression came to consciousness in the messianic idea which was expressed in the anonymous literary accumulations of the post-exilic period. ${ }^{2}$ On the one side, there was to be a unification of the ethical consciousness; on the other there was to be the establishment of a kingdom in which the contradiction woùld be no longer necessary. The ethical teaching of Jesus was an attempt to realize these two messianic ideals-the former the contribution of the prophets, the latter of the priests. The prophetic movement, as we have seen, had broken down because its universal ethical principle was given no means of objectification; whereas, the priestly movement had failed because a great gap was left between the particulars of life and the universal principle represented by law, and the objectification secured remained purely formal. The post-exilic movement was but a compromise between these two. Jesus, however, sought to reconcile the ideas underlying both movements by getting a generalization which would explain the principle on which each had proceeded. 3

I Montefiore, op. cit., 4ro ff.

2 Ibid., $40 \mathrm{r}$ ff.

3 Dewey, ibid. 
On the prophetic side Jesus held that the obedience to God was a state of the will and did not consist in external acts. If the moral life was not only within but consisted in a willingness of the soul rather than an understanding, every individual could realize it. The aristocratic system of the Socratic school was unnecessary, for every man, even the most ignorant, could be willing to do God's will. On the priestly side, Jesus developed the conception of the kingdom of heaven, the community within which the right attitude, faith, could find expression. The truth underlying the priestly movement was that the moral motive must find expression. It was the social principle-the consciousness of the necessity of organic, institutional expression of the moral impulse-for which the priestly movement had stood; while the prophetic movement had stood for the principle of individuality. Jesus made the disposition and the expression of the disposition in and through a universal society reciprocally necessary and thus gave an ultimate ethical statement. ${ }^{x}$

This assertion of the essential value of the individual and of the identity of the interests of the individual and the interests of the whole society was a sublime ethical generalization; but because it was a universal statement and was not made in terms of any existing society, it had to be purely formal. The interests of the individual and the interests of society were not identical; and the attempt to act as if they were led to the tragedy in the life of Jesus. With the early Christians the statement of the principle was the all-important thing; but in time it was found that the universal had to be realized in the particular. It was the relation of the particular to the universal that became the chief practical, as it was the chief theoretical problem of the Middle Ages. This, however, is a matter for further consideration.

\section{THE CONTRIBUTION OF GREECE}

To understand the nature of the contribution of the Hellenes, it is necessary to examine the development of their technical arts and the institution of the city-state. These two were recipro-

I Dewey, ibid. This paragraph is practically a condensed quotation. 
cally cause and effect; and so the art consciousness and the political conceptions may be studied together. The peculiar nature of the Greek development was due to geographical conditions and to the fact that the Greeks were able to appropriate so easily the results of earlier civilizations. Except for these circumstances, there is no reason for believing that they would have had much more importance than many other Aryan tribes.

The earlier internal development of Greece.-The geographical influences made themselves felt before the people came into contact with older civilizations. The country of the Hellenes, whether insular or mainland, was such that no great mass of humanity could be concentrated in any one section. On the mainland the plains are narrow spaces hemmed in by the hills which ascend to the peaks. But the sea was always near at hand, and afforded a means of outlet and of intercommunication. Thus a seclusion of the tribal home was associated with a means of intercourse between the tribes. These two conditions had much to do with the immediate political development and with the development of the intellectual and imaginative powers of the people.

The Ionians, who first settled along the Asiatic coast, early learned the art of navigation and spread over the neighboring coasts, first as pirates, later as permanent settlers. The people were isolated and crowded together in small groups, yet the open sea brought the various small groups into relations with one another. The ancient tribal organization of a nomadic people had to break down under these circumstances, and the local clans were subordinated to the "city" organization. The latter was not at first a town into which all the people were gathered; it was simply the organization of the whole of a small community about the center where were located the sanctuary and other public buildings used for the purposes of the community life. ${ }^{x}$ The conditions of confinement within narrow limits led to the break-down of the patriarchal family with its blood-feuds and narrow exclusiveness. The tribes and phratries, survivals of an older system, were strictly subordinated in the interests of the city. This isola-

I Fustel de Coulanges, The Ancient City, I67-87, 231-38, 293-98. 
tion of the small city, together with the constant contact with other communities, brought to consciousness the value of the community. The interest of the people centered in the community rather than in the immediate domestic and industrial pursuits. Association with other communities at the shrines and in the games intensified this appreciation of the city-state. Later on, this appreciation was turned into intellectual concepts which served as the basis of wider political organization.

The political organization followed, of course, the industrial organization. In the earliest period, as shown in Homer, the pastoral organization was still in existence. The people were free, but the great chieftains had come to constitute an aristocracy. The relatively small number of slaves were captives in battle, and were of no economic importance except as domestic drudges or as assistants to their masters in common labors. ${ }^{x}$ There was scarcely division of labor sufficient to call for a separate artisan class, much less for a servile class. Necessary industries were carried on in the household, and the master would co-operate with the artisan or servant. One son of Priam prepared materials for making wagons; another, Paris, worked with the skilled carpenters on his own dwelling; and Odysseus made his bedstead and was skilled in ship-building. ${ }^{2}$ There was no disgrace attached to manual labor during this period.

With the final settlement in their historical land, the agricultural organization soon came to overshadow the pastoral. But the Greek lands could never yield very bountiful harvests; so no massing of humanity such as took place in the Nile and Mesopotamian valleys could ever take place in Greece. When the population began to press upon the food supply, grain had to be imported from other countries, the people turning to other industries; but the population could increase only as commerce was built up by the people themselves. This prevented the destruction of the city organization. But during the agricultural period, before the pressure of population had led to any considerable exten-

I Wallon, Histoire de l'esclavage dans l'antiquite, I, $65 \mathrm{ff}$.

- Iliad, xxi, 37; vi, 314; Odyssey, xxiii, I80 ff.; v, 243 ff., etc. 
sion of commerce, the chief families became a land-holding aristocracy, the smaller cultivators becoming dependent upon them almost as serfs. The conquered population fell entirely into this position. These, however, were hardly the property of the landholder, but were attached to the soil. ${ }^{\mathbf{x}} \quad$ The aristocracy of landowners looked down upon the agricultural laborers and also upon the few artisans who were required for domestic industries. The great landholders controlled industry without taking part in it themselves. In some places, as Sparta, the workers were entirely excluded from the rights of citizens; in others, as Thebes, one who had been free from industrial pursuits for ten years might hold office; in others, as Aristotle says, it was possible for an artisan to be both wealthy and a citizen. In Athens the agrarian question became so pressing that the oligarchy was unable to put down the mutinies, and called in Solon to revise the laws.

The next stage in Greek social development was that in which the industrial classes began to get control. Here we begin to find the bearing of the industrial development and of the art consciousness upon the general social life of the Hellenes. From this point their civilization begins to have its peculiar value. The peculiar nature of the technical and artistic development was due to the imaginative powers of the Greeks and to their early contact with advanced civilizations.

Leaving the latter influence for further consideration, some account must be given of the mental characteristics with which the Greeks were endowed when this contact came. These were due in part to geographical conditions and in part to the social life which, as shown above, was largely determined by those conditions. Their imaginative powers were probably due less to the presence of mountain and sea than to the social conditions which the physical environment produced. The artistic temperament was further developed by the appropriation of the arts from other peoples; but had it not been for the racial or specially developed imaginative powers of the Greeks, there could have been no highly developed art. Witness here the Phœnicians.

I Büchsenschütz, Besitz und Erwerb im griechischen Alterthume, I27, r54; Wallon, op. cit., I, 94-104; Curtius, History of Greece, I, 317-21. 
Aside from the possible direct influences of the physical environment, the mental characteristics of the Greeks may be partly explained by the nature of their occupations. The pastoral life was never entirely abandoned; the agricultural life could never be reduced to the dead monotony which prevailed in the fertile Nile region; the commercial activity became very great in time, but not soon enough to make the Greeks a race of traders. Here, then, was a diversity which could beneficially influence the life of a people situated as the Greeks were. Again, their mental peculiarities may be partly explained by the character and organization of the social life. It was impossible for the Greeks to become a conglomerate nation; it was equally impossible for them to live in isolation. Each tribe profited by the experience of all the others. On this account the individual was never swallowed up beyond recovery in his own tribe. In the intercourse of the representatives of the various tribes at the sacred places, and more particularly in the competition of the games, the individuality of the champions was brought out, at the same time that the consciousness of the interests of their respective states was emphasized. In the religious festivals and gymnastic contests art ideals first came to consciousness. Then, when the technical skill was acquired, the plastic way of looking at things and the admiration of the attitudes assumed in the dances and gymnastics enabled them to enter quickly upon their career as artists.

The explanation here given of the causes of the Greek spirit is far from complete. Doubtless many forces were shaping the Greek mind long before it was brought under the influences mentioned. These, however, were probably the most important of the shaping influences. With the appropriation of the technical skill which enabled them to express their peculiar spirit, the Greeks immediately took their places as leaders of civilization. The tribes of the Homeric period were probably in about the same stage of culture as some of the more advanced Pacific islanders when first visited by white men; yet they were superior in many respects to the Egyptians and Chaldæans who were then enjoying such a high culture. Their imaginative power and freedom 
of spirit were bound to work out tremendous results, provided the technical skill which the older peoples had acquired could be learned without shriveling up this latent power. But this could never have been done, this spirit could never have got control of its physical environment as it did, had it not been shown the way by those older civilizations.

The influence of Egypt and Phonicia.-In order to understand how a technique was not only acquired but was kept free, it will be necessary to trace the steps by which technical skill developed from the beginning and the peculiar circumstances connected with its transference to the Greeks. ${ }^{x}$ The significance of this earlier development is all the more marked when we remember that the Greeks of the time of Pericles were farther removed from the beginnnings of oriental culture than from the present time.

The Greeks frankly admitted that they had learned art, science, and industry from the Egyptians; and, indeed, did not themselves realize what a tremendous advance they had made beyond their teachers. They could not have made this advance, had not considerable technical development gone on among them, along with the development of self-reliance and a capacity for selfgovernment. They were able, even better than the Phœnicians, to learn the method of the Egyptians, leaving the cumbrous customs of the latter aside. This was but natural, since the Egyptian customs had no sacredness to the foreigners who observed them. Hence, the Phœnicians abstracted the principles of the alphabet from the Egyptian system, discarding the clumsy hieroglyphs and determinatives which seemed so necessary to the conservative inventors; while the Greeks abstracted the principles of geometry from the rule-of-thumb methods of triangulation and mensuration employed by the surveyors of the Nile region.

I The following discussion is intended both to show the actual influence of Egypt on Greece, and to explain the nature of the development of technique and its influence on social conditions. For the former point, it might be sufficient simply to state some of the results of Egyptian culture appropriated by the Greeks; but since the process is to be traced in dealing with all western civilization, light can be thrown on all our later discussion by giving the Egyptian development a fairly complete treatment. 
Habits of regular industry do not develop spontaneously in man. They were attained in Eygpt and Chaldæa long before the Hellenes began their national life; but they were secured either through the despotic power of the ruler over the people, or through the control of industrial life by the consecrated institutions of caste. ${ }^{x}$ The concentration of large populations which made industrial development possible was, of course, conditioned upon the fertility of the soil upon which some vigorous people might enter. The rich soil and mild climate of the Nile and Mesopotamian valley made those sections the cradles of civilization. The soil was so rich and so easily worked that almost no agricultural labor was required, and where the soil needed breaking up, the simple Egyptian hoe was sufficient. ${ }^{2}$ The people who came into the Nile valley were savages who entered at once upon the agricultural life without passing through the nomadic stage which characterized all Aryan and Semitic peoples. The practice of tracing the descent in the female line, which long prevailed in Egypt, and the consecration of girls of noble families to the service of Ammon and lives of immorality, could not exist among a people who had passed through the pastoral stage. ${ }^{3}$ The legendary history also indicates that the people had been cannibals, and, though living in part on vegetable food, did not know how to cultivate the soil. Evidently a hunting people had been driven into the narrow district, and, finding means of egress difficult and the game supply limited, had been obliged to turn its attention to the cultivation of the edible grasses which were already flourishing in the rich valley. Everything points to the fact that the people had emerged from a savage state at a period long before their first written records, and had reconstructed their social customs and religion on the basis of agricultural life.

The people entered naturally upon agriculture, though advance must have been by slow stages, by cut-and-try methods, and without any general conception of the technique of the in-

I Grote, History of Greece, III, chap. xix, passim.

2 Cf. Maspero, The Dawn of Civilization, 66, 67.

3 Lippert, Kulturgeschichte der Menschheit, II, 6 ff. 
dustry. But population was bound to increase with the increase of the food supply; and circumstances soon made necessary a working co-operation among the people. This was brought about by the methods of irrigation. Cultivation was easy near the river and in the neighborhood of the natural reservoirs formed in depressions after the subsidence of the Nile. Irrigation in these regions was carried on for countless generations before the kings of the historic period appeared. The work began at various points spontaneously. The canals would be prolonged until they met others, and the system would have to be improved with the demands of an ever-increasing population. The men of a favored district would utilize the water to suit their own needs, not considering whether they were injuring their neighbors by depriving them of a supply or by flooding them. Perpetual strife resulted, until it became imperative that the system of distribution should be co-ordinated. The Nile thus determined the political, as well as the industrial, constitution of Egypt. ${ }^{x}$ The system of co-ordination secured was like that which always arises when some men are dependent on the mercy of their more fortunate fellows: those who held the lands nearest to the water became a ruling nobility, permittting water to descend to others on condition that the latter should pass under their control.

The earlier industrial development had consisted in the gradual development of well-adapted habits in a favorable environment. Now, however, sufficient advance had been made in social organization to permit of the manipulation of the technical skill of the masses by those who had arisen to powerful positions. The coordination of the systems of irrigation meant the putting of the means of control of agriculture in the hands of a ruling class. The lands held by the government were of vast extent, while most of the rest were held by the nobles as fiefs. Thus the products of the soil-the real wealth of Egypt at all times-passed into the hands of the ruling class, while the technique of the industry was no longer controlled by the workmen themselves. This was the essence of slavery, and it was only a question of time

$\therefore$ Maspero, op. cit., 70 . 
when the system should become extensive and slave hunts begin. These latter began about the thirty-ninth century, в. c. Before that time, the condition of the free peasants must have been sinking into virtual slavery, but no extensive employment of foreign slaves had begun. Wars had been few, and the tribes on the border were not numerous. But wealth had been increasing, and hence some men were becoming very powerful; and the demand for labor was becoming pressing. Warlike expeditions were undertaken, and slaves were brought back. ${ }^{x}$ Slave hunts became more numerous, and by the time the tombs of the Old Empire were erected, the free peasants had practically disappeared. ${ }^{2}$ With the introduction of slavery on a large scale the condition of the original peasants became infinitely worse. They were not mere chattels, but their position as tenants of the Pharaoh was essentially servile. ${ }^{3}$

The surplus of agricultural products naturally led to the development of many other industries. Advance was slow but steady. The Egyptians were always afraid of losing what they had gained; hence they clung to methods after they had once been learned, and preserved ancient forms after they had really become able to improve upon them. That which did most to advance their higher artistic production-and though extractive industries were the basis of Egypt's greatness, the work of her artisans had the more important influence on Greek civilizationwas their belief concerning the future life. With them the soul was immortal, but its immortality depended in some way on the body. Without the body the soul might become dissipated and lose its personality. Therefore the art of the embalmer became of great importance. But with them, as with other more primitive peoples, everything had a soul whose persistence depended upon the preservation of the object. The soul of the deceased man

×awlinson, Ancient Egypt, I, chap. xi, passim.

2 Erman, Life in Ancient Egypt, 99-ror.

3 It is true, however, that the introduction of slavery on a large scale furnished laborers for the mines, and thus freed the peasants from forced labor of that sort. Cf. Maspero, Dawn of Civilization, 356, $42 \mathrm{I}$. 
had to subsist on the souls of viands and to find its enjoyment in the souls of things which gave enjoyment in this life. The preservation of all these souls was best secured by the preservation of the actual bodies; but to make assurance doubly sure portrait bas-reliefs and statues, whose souls would be as real as those of the real bodies of which they were replicas, were also provided, so that if the body should be destroyed, the soul could maintain its personality. If a man's wealth permitted, he would have many such images of himself, his favorite scenes, and all that he valued most on earth placed in his tomb. All of this meant a tremendous statue-making industry; and the fact that likenesses were wanted led to a constant improvement in the technical skill of the sculptors. It prevented, however, any effort at idealization, such as raised Greek art to so great a height; for when a man's soul depended upon the faithfulness of the likeness, he could not venture to have the latter flatter him unduly. The tombs and pyramids built for the reception of these images, the elaborate temples required by the powerful priesthood, the residences of the luxurious nobles, and the public works of the government, the monopolistic owner of the products of the soil-all called for skill and numbers in the building trades and in the industries concerned in the ornamentation of the edifices. Innumerable minor industries were readily added to these, and there was no reason why the Egyptians should not enjoy every luxury known to the ancient world. The growing luxury, increased still further by the passion of the Theban kings for great public works, had much to do with the extension of slavery, for thus the industries could be expanded and the works carried forward without disturbing the labor market.

The advance was always by very slow stages, and a process once introduced tended to persist unchanged. The method or technique was never freed from the earlier stages through which it had passed. Just as the scribes, with all their speed and skill, could never pass entirely from picture writing to an alphabet, even though an alphabet really existed within their own system, so all other arts were burdened with the survivals of their own 
past. Indeed, it is noticeable that the later buildings and statues are more conventional than the earlier. The art which the Greeks studied was inferior to that which was then buried under the sands of ages and in the depths of cities of the dead. The method of social control of the industrial and artistic processes had destroyed the earlier invention and creative power. There was a constant advance in technical accuracy, for that could go on under servile conditions; but when the Greeks began to visit Egypt about the middle of the seventh century, B. C., the power of initiation and freedom was gone. ${ }^{x}$ The conservatism of the Egyptians had been able to produce for them a number of type forms of architecture and sculpture which may have been of more value to the Greeks than living examples of inventive genius. The conservative tendency of the Egyptians was further strengthened by their isolation. Egypt was a self-sufficient country. Almost all necessary raw materials were found within the country; industrial arts of almost every sort were developed under the Old Empire, before other peoples had begun their industries. The mountains and deserts served to protect the country from invasions, and gave security for peaceful occupations; so that there was little incentive to carry on intercourse with other peoples. ${ }^{2}$ There was thus every reason for the feeling that methods which had been developed in Egypt in the past were perfect. And since many of these had received religious consecration, further improvement was not conceivable.

Furthermore, since these methods were stationary, they could be controlled by superiors. No premium had to be placed upon individual initiative. The secrets of the processes could be mastered by outsiders, and green hands could be initiated by the controlling agents. This disadvantage of the laborer was further accentuated by the fact that most of the workmen had no control over the product of their labors. The products of the soil, save enough for bare subsistence, passed directly into the hands of the ruling classes. The great buildings were, of course, directly

× Perrot and Chipiez, History of Art in Primitive Greece, I, I7.

2 Cunningham, An Essay on Western Civilization in its Economic Aspects, I4. 
constructed by the agents of the persons who were to use them. The minor industries were not so narrowly bound down, but having to do chiefly with luxuries, furnished little for the consumption of the laborers. The extension of slavery, which naturally came with the growth of the militant spirit, left the ordinary free peasants or artisans in a pitiable condition. They were uniformly ill paid and were subject to corporal punishment by government agents. ${ }^{x}$ The artisans were divided into companies after the model of the army. The Theban dynasty was initiated by arms when the Hyksos were overthrown, and was maintained by arms. All large industries were organized on the plan of the army, and great companies of slaves were kept for the public works. ${ }^{2}$ The workmen were considered only en masse. By this organization and command of human strength, the Egyptians were enabled to accomplish works which were impossible under any other conditions at that time.

In order, however, that the labor of the masses could be thus directed and controlled, there had to be a class of artists and superintendents as much higher than the rank and file of the industrial army as the generals were above the common soldiers. These were the men of genius or executive ability whose services were indispensable for the social control of industry, and who therefore received monopoly compensation. The details of the work of the great buildings could be left to the ordinary semi-free or servile workman; but the man who understood the whole plan and could direct the whole process was held in high esteem and might even be a noble. The conventional figures of gods and demi-gods could be produced mechanically by men of no artistic ability, though possessing technical skill; but the great portrait statues were the work of individual artists of considerable talent, xi, passim.

x Erman, Life, chap. xvii, passim; Rawlinson, Ancient Egypt, Vol. I, chap.

2 Erman, loc. cit. Instances of strikes are cited hy Erman, which show that the enforced association of the artisans made it pussible for them to co-operate for their mutual benefit when their rations were too long delayed through "red tape" and official carelessness. But these strikes never changed the general condition of the industry; they simply prevented the laborers from starving. 
whose ability was scarce and well rewarded. So it was with nearly all professions and trades. ${ }^{x}$ The peasant-serfs, whose industry produced the greater part of the wealth of the nation, were completely under the control of the higher powers.

Now when the art and industry of Egypt were carried over to other peoples, two changes would necessarily take place. First, the essentials only would be transferred, the conventionalities both of product and method which had been carried on for centuries, thereby becoming sacred to the Egyptians, being wholly discarded by those for whom they had no sacredness. Secondly, those who were able to learn from the Egyptians and apply the methods under new conditions would have to be freed from social control. Slavery might afterward be introduced; but the technique of industry would at first be so completely under the control of the artisans and traders that society would have to pay well for their services. This is what actually took place in both Phœnicia and Greece. A trading aristocracy arose in both places. Whether the whole industrial population should be permanently elevated would depend upon the control of the product as well as the technique of industry. In no ancient society did the product pass under the control of the laborers; hence only the initiators and leaders of industry occupied high position.

The contribution of Phœnicia to the Greek development did not differ greatly in nature from the appropriation which the Greeks made directly from Egypt. The first contact of the Greeks with civilization was through the Phœnicians. It was only after the former had made considerable advance in art and industry that they went to Egypt and learned vastly more than their teachers ever could learn. The Phœnicians had been forced to become seamen by the character of their habitat. When the increase of population began to press upon their scant food supply, they turned their maritime habits, their fisheries, and their salterns to account in trading. Thus Phœnicia became the channel through which the civilization of Egypt and Chaldæa

Rawlinson, op. cit., I, 493-548. 
was carried to Europe. ${ }^{\mathrm{I}}$ She had no opportunity to develop civilization from the bottom, but she could pick out those elements of older civilizations for which other peoples were willing to pay. Her commerce was esssentially one of exploitation, but she none the less assisted in the development of Greece. She invented practically nothing, but so keenly picked out the essential from the valueless from among the inventions of others that she actually made new contributions to the world. She controlled the whole Mediterranean trade of the Egyptians, and soon learned to manufacture in her own factories goods. which better satisfied the demands of both her own luxurious citizens and her semibarbarous customers, than did those brought from Egypt. She furnished the architects and master-workmen to build the temple of Jehovah at Jerusalem, and sent forth her goddess Astarte to become the Aphrodite of the Greeks.

One peculiarity of the Phœnicians was the fact that, although pupils of the Egyptians and Chaldæans, they never borrowed from their teachers the composite and grotesque gods with-human forms and heads of hawks, crocodiles, and other animals. Their gods were always anthropomorphic. Their interest was predominantly social; they paid little attention to nature. Hence, when they began to provide the still barbarous Greeks with idols which the latter immediately began to imitate, they did not put into their hands any of the grotesque combinations of which the dwellers on the Nile and Euphrates were so fond. Their execution was rough and awkward, but it turned the Greeks into the only path by which true art could be reached. Even the coarse representations of differences in sex may have served to lead the Greeks to a close study of the human figure, thus assisting in the development of their art consciousness. ${ }^{2}$

Aside from the stimulus given to Greek industry by the importation of Syrian and other products, the establishment of fac-

x "She assumed the office of ubiquitous broker, of an intermediary moving to and fro between the East and the West."-Perrot and Chipiez, Art in Primitive Greece, I, 4.

2 Perrot and Chipiez, History of Art in Phonicia, I, 83. 
tories on the Greek coasts, especially for the utilization of the fish dye to be secured there, set the Greeks an example which they were not slow to copy. And so, in art, architecture, manufactures, and the use of the alphabet, the pupils were soon able to set models for their masters. The Phœnicians were a race of merchants, and never had sufficient imagination to give artistic form to that which they produced. Nor did they ever contribute new inventions. They attained a high degree of skill in the use of hand and eye, but never attempted to give expression to ideal conceptions. They gave the world the alphabet, but themselves used it for little more than book-keeping, and never produced a literature. The Hellenic genius soon emancipated itself from the narrow utilitarian precepts and example of Phœnicia; but the contact with the latter had given the barbarians their first important lessons in the arts of civilized life. The Greek arts and manufactures continued to improve, and finally Greek commerce crowded out the Phœnician. The Greeks also began to go to Egypt and get at first hand much that their former teachers had passed over or imperfectly interpreted. It is possible that the Hellenic development would have been stunted, had not some of its elementary stages been thus shortened by a partial generalization of existing civilization by an intermediary. In principle the Greek and Phœnician processes were the same. Both consisted in the generalization of older civilizations which had been worked out by peoples that were unable to generalize them. Except for furnishing a sort of abbreviated copy of Egyptian and Chaldæan civilization, the Phœnicians contributed little to Europe. ${ }^{x}$

Period of Athenian expansion.-By the seventh century B. c.

I The works particularly consulted on this section were Renan, Mission de Phénicie; Pietschmann, Geschichte der Phönizier; Movers, Die Phönizier; Perrot and Chipiez, Art in Phonicia.

I have not thought it desirable to trace the influence of Babylonian civilization upon the Greek development, as no difference in principle appears in that influence. There was this slight difference: while the Egyptians contributed conventionalized type forms, the Chaldæans contributed richness and variety. The main contribution, however, was the stimulus to the development of technical skill and the desire for luxuries. 
the Greeks had entered upon their third economic stage-the commercial and industrial. A little after the middle of that century, the commerce of Egypt was opened up to them, and about the same time their former teachers, the Phœnicians, were overthrown by the Assyrians. From this time their commercial expansion was very rapid. It was brought about both by the extension of markets and by the inspiration received from the new patterns found in foreign lands. Articles of luxury were made for exchange for the raw materials of the richer lands of Asia Minor. Colonies were founded and the foundations laid for a great commerce. ${ }^{x}$

As we have seen, one of the important consequences of this contact with older civilizations was the freeing of the technique of industry. What the Greeks then produced was the idealization of the best that others had been producing without trying to reach ideals. All of their technical processes were therefore more or less artistic. The older processes of native development were necessarily revolutionized by the reaction of the new methods upon them. Without this a higher development would doubtless have been impossible. The ancient gods had been shapeless stones and sticks. Later, when gods were multiplied, new forms were made in imitation of the older ones. The trade was in the hands of certain families which were united in gilds. Pious reverence forbade any improvement in the images of the gods. There was thus no possibility of advance in artistic products and no stimulus to advance in technical methods. But when the technical skill was developed in the newly established industries, and when admiration for the athlectic form led to a desire to perpetuate it, lifelike images of the victors in the games were produced. With these images of great beauty the primitive idols compared very unfavorably; and so they were made over into forms which idealized the human figure. When the god was given artistic form, reverence still forbade that his features should be too individual; hence a greater generalization was made, resulting in still higher type forms. And the Hel-

× Büchsenschütz, Besitz und Erwerb, 38r. 
lenes being under no such animistic bondage as that to which the Egyptians were subject, the likenesses of human beings could be made to flatter them and idealize their real forms and features to the extent of the artists' ability. By the middle of the fifth century art had been emancipated from the necessity of reproducing invariable forms. Similarly, architecture idealized the rustic booths which had formerly served as shelters for the gods, and produced the magnificent temple. ${ }^{x}$

An added impulse was given to the artistic and technical development after the Persian wars; and this was most marked in Athens. That city had to be completely rebuilt after the victory at Salamis. The leading part taken by Athens in the glorious struggle made her the natural head of a group of states and colonies. She was able to exact from her allies a vast tribute which, together with the gains of her own industry, so expanded by the national exaltation and favored by the years of peace, gave her ample resources for all her great undertakings. This national exaltation also led to the development of individual genius; and accordingly we find in the generation succeeding the victory a number of men who had caught the spirit of their national greatness. At the head of these were Pericles and Phidias who directed the political and artistic life of the capital. ${ }^{2}$ So, after several centuries, during which the technique was patiently developed, art was freed and brought to its greatest perfection. The values of experience were idealized and objectified. No other people ever so completely generalized the principles which lay behind human products. The Greeks never copied or imitated the products of others, but adapted the technical processes which they had abstracted from older civilizations to their own uses. They thus formed the habit of separating meaning from existence and

x Cf. Grote, History, III, chap. xxix; Duruy, History of Greece, II, 188-94; III, $92 \mathrm{ff}$., $\mathrm{I}_{2} \mathrm{ff}$.

I do not forget that the remains of Greek (?) architecture and sculpture at Troy, Tiryns, and Mycenæ show considerable merit. So do the rock paintings of the Australians and Bushmen. It is doubtful whether the rude and cumbrous methods would ever have been freed without the influences I have described.

2 Cf. Curtius, History, II, I-III, 538-46, 637-4I. 
of finding reality in the meaning rather than the existence. With them every experience came to have an eternal value, a value lasting after the experience had gone. As they advanced they became more conscious of this typical, ideal element; yet they could conceive it only by visualizing it. Experience had to be formulated in terms of objective individuality; but they did not rest with the simple objectification of particular experiences, they attained objective types which could be regarded as adequate expressions of their absolute reality. This conception of the reality as being found only in the meaning, which yet must be given objective form, was a contradiction. It meant the defining of experience in static terms. The type, however, was that which expressed the reality, as distinct from the mere external form which struck the senses. This is why Greek art could attain such high excellence. ${ }^{x}$

This peculiar characteristic of the art consciousness of the Greeks is the key to their ethical contribution. Living became an art with them, the principles of which could be generalized and applied to the guidance of conduct. The universal was the real, as with certain mediæval philosophers; but the universal had to be got from the particular and then given expression in type form.

The social effects of the industrial development were most important. The freeing of the technical processes necessarily led to the freeing of the artisan and artist from servitude or any form of traditional control. Creative genius had to be free; and the initiation of a new movement is always a creation. The carrying-over from another people was the same as a creation in this case, because the technique had to be generalized. In the time of Athenian greatness Phidias was the equal of princes and nobles. Many others shared the greatness of their chief. The merchants, especially those who were carrying on commercial dealings with foreign countries, and the artisans, except those whose work was purely mechanical, enjoyed great prosperity.

I Dewey, ibid. Dr. Dewey has also shown the importance of the fact that the Greeks passed their ideals into literature and worked out their standards as images which then depended for their form upon the imagination of the artist. 
The immediate effect of the rise of industry was the breaking down of the old landed aristocracy. The power first passed into the hands of the trading class. Beginning with the legislation of Solon encouragement was given to manufactures and commerce. ${ }^{x}$ The first beneficiaries of this legislation were the metics, but gradually citizens who did not belong to the landed aristocracy became wealthy and powerful. The common people associated with the new aristocracy against the old, and finally demagogues arose who appealed to the masses against both the landed aristocracy and the wealthier merchants and attempted to make over the laws and customs in the interest of the democracy. These tyrants resembled those who arose in the Italian republics after the merchant class had overthrown the landed nobility. This was the natural development of democracy. ${ }^{2}$ Since the common people could not get the control directly in their own hands, they gave it to the tyrant. As Plato made Socrates say, the oligarchy destroyed itself by its very love of wealth, and the democracy destroyed itself by its very love of freedom. ${ }^{3}$ The tyrant became the leveling agent, tending to free slaves, to raise the mob to prominence, and to destroy distinctions generally. This state of affairs was one occasion of the Socratic philosophy.

While, however, the classes which introduced the arts of life into Greece and adapted them to Grecian needs had to become free, and while they steadily advanced in wealth and social position, there was always a vast amount of merely mechanical imitative work to be done, for which slaves and inferior free artisans could be employed. As soon as a new industry was established, the economies to be derived from division of labor would lead to the employment of inferior artisans wherever possible. The rapid expansion of industry-beyond the ability of the existing supply of labor-led to the introduction of slavery on a large scale. Periander's prohibition of slave labor in Corinth, which

I Büchsenschütz, Besitz und Erwerb, 322, 323.

2 Plato, Republic (Davies and Vaughn ed.), viii, 294. "That it is a transformation of democracy is all but obvious."

3 Plato, loc. cit. 
was intended to encourage industry, had an opposite effect because the supply of free labor was insufficient. With the rapid extension of slavery at Athens during the period of her greatness, free labor still enjoyed great prosperity, both because of the unceasing demand for labor, and because the esteem in which the higher artisans and artists were held reflected some advantage to all skilled workmen. The artisans having acquired political power during the times of greatest prosperity, it was impossible to deprive them of their political rights in the times of commercial depression and demagoguery. During the latter period, the lesser artisans were in a miserable condition and could not themselves control the cities, but the democratic principle having been admitted, they could place the power in the hands of tyrants. The artisans were banded together in gilds; but these had no economic significance, being neither agencies for police control, as at Rome, nor of self-protection, as during the mediæval period. ${ }^{3}$

But notwithstanding this continuance of political power which Plato so much deplored, there came a virtual economic slavery which justified Plato in regarding all artisans as slaves. This was brought about by two circumstances. The more prominent of these was the mass of slave labor which more than supplied the requirements of industry after the Golden Age had passed away. After the public works of Pericles were completed the demand for labor must have fallen off to such an extent that many artisans were left without employment. Free laborers would, of course, be turned adrift long before slaves would be withdrawn from the languishing industries. The Peloponnesian War called into service every available man; so that the industry that was carried on at home fell largely into the hands of the servile population. From that time the unsettled political conditions both within and without the city made a prosperous industrial life impossible. The inventive genius was no longer needed. The artist and the artisan could satisfy all demands by merely imitating the products of the golden Age. The few poets, dramatists, sculptors, and skilled artisans who could be produced

× Büchsenschütz, op. cit., 33 r. 
in such a society found freer scope for the exercise of their talents in Macedonia or other foreign lands. ${ }^{8}$ It is true, a high degree of technical skill was still frequently required, but the work was largely mechanical and could bring no very great rewards to the workman. Not only could slave labor be used in the ateliers as steam is used in modern factories, but the requirement was usually for small fragments of a product from each laborer, and few men had abilities which could command respectable reward. ${ }^{2}$ It was on account of this feature of specialized labor that Plato and Aristotle held to the theory of the natural servile condition of the working classes. They were servile, both because they could no longer control the technique of their industries, and because the slaves could do their work equally well. ${ }^{3}$

The other causes of the degradation of the working class had to do with phenomena of consumption. Hellenic, and especially Athenian, manufactures were largely such as passed beyond the control of the laborers. The great public works, of course, were of such a nature, except as they could contribute to the enjoyment of all classes. The general products of industry were luxuries for the consumption of the rich, or were manufactured expressly for barbarians or less cultured peoples who were largely exploited. ${ }^{4}$ There was no possibility of bringing such products under the control of the artisans, for the latter could consume none of them. The condition of economic advance is the elevation of consumptive demands. This can not take place if the only products of industry are the bare necessaries of life and such goods as are hopelessly above the producers. In times of prosperity the Athenian would receive all the food and coarser commodities he needed; but, except in the case of men whose services were in such demand that they arose far above their former station, it was impossible for the artisan to receive more than these neces-

× Curtius, History, III, 556, 557 .

2 Büchsenschütz, op. cit., $34 \mathrm{I}$.

3 For a discussion of the number of slaves in Athens, and the manner of employment, vide Wallon, Histoire de l'esclavage, Vol. I, chap. viii, esp. $245 \mathrm{ff}$.

4 Büchsenschütz, op. cit., 317 . 
saries, because there was nothing else produced except commodities that were too far above him to be hoped for. Without a mass of products between the two extremes of the necessaries of life and luxuries, there could be no gradual rise in the standard of living; and without the latter there could be little control of the products of industry by the laborer. ${ }^{x}$

Thus it came about that the most wonderful artistic genius the world has ever known, combined with a marvelous development of technical skill, could not prevent the working classes from dropping to a condition closely resembling that which we have found to have prevailed in ancient Egypt. The working classes continued to possess a political power which rendered them dangerous, but their actual condition was such as to warrant the judgment of Plato and Aristotle. Controlling neither the technique nor the products of their industry, they could not be other than economic slaves. ${ }^{2}$

Period of decay and reflection.-The economic decay just described was accompanied by the political decay caused by the Peloponnesian War. The social life of Greece came to consciousness when the industrial development had passed its zenith, when the political system was decaying, and when the independence of the states was being threatened. The social philosophy was most highly developed at Athens. There the philosophers, to explain society, used the concepts which had been worked out for the explanation of physical phenomena by the philosophers of Asia Minor. The first philosophers to attempt to apply these principles to the conduct of life were the Sophists. These teachers held that the art of life could be followed by the individual under any political conditions. This was the logical conclusion of the tendency to abstract general principles from particular things. But the Sophists, unlike the Socratic philosophers, attempted no reconstruction of the social order; they simply reacted against

I This important fact concerning consumption will receive frequent illustration throughout this essay. Its significance will be more apparent later.

2 "Ainsi le travail libre, garanti, imposé par Solon, étendu par Pericles, ne suffisait plus à élever les classes inférieures audessus de l'indigence."-Wallon, op. cit., I, $\mathrm{r}_{5} \mathrm{I}$. 
it. So the first effect of the abstraction of the principles of conduct was to bring the individual into prominence. Both the Sophists and Socrates were coming to see that living is an art, a matter of law and order, the principles of which could be discovered and applied. An emphasis was laid upon the individual; but he was to live according to rational principles, not according to mere command as with the Hebrews. ${ }^{x}$

The social consciousness of their origin and end prevented the Athenians from accepting the negative sophistic teaching: they distinguished the spirit of their social life from the outward forms which were crumbling away. How the center could be transferred from social custom to individual reason, and yet the social idea and standard be maintained, was the problem of Socrates and Plato. They go back to the methods of the trades and arts for their standards in teaching an art of life. ${ }^{2}$

This emergence of an art of life with professional teachers can not be thoroughly understood, unless it is viewed as a crowning result of a general tendency at this stage of Greek civilization to substitute technical skill for traditional procedure and empirically developed faculty. In the age of the Sophists we find, wherever we turn, the same eager pursuit of knowledge, and the same eager effort to apply it directly to practice. ${ }^{3}$

The fault which Socrates found with the artisans and artists was that, although they understood their particular arts, they did not perceive the social values of them. The end of all these particular ends must be known. But since the artisan did not see the relation of his particular art to the general art of life, he could not be free. Socrates and his successors held that only the man who can appreciate the end of life is wise; those who devote themselves to minor ends are base. Socrates showed that the difficulty in life is that of connecting the particular and the universal. Like the Sophists, Socrates addressed individuals, but unlike them, his aim was to bring individual ends and the social end into harmony. But this could not be done by the

I Dewey, ibid.; Wundt, Ethical Systems, 5, 6.

2 Dewey, ibid.; Windelband, History of Philosophy, $77 \mathrm{ff}$.

3 Sidgwick, History of Ethics, $2 \mathrm{I}$. 
Athenians without a disintegration and a reconstruction of their social life. The existing social institutions had grown up in a haphazard way, while the technical processess had developed to such an extent that they could be reduced to order within themselves; and since men's lives are unified, conceptions of order in general had to arise. These institutions could not be generalized as they existed; hence Socrates was regarded as an enemy of society. Like Socrates, Plato recognized that the problem was the harmonizing of particular and general ends; but unlike his master, he became reconciled to the problem. He partially separated the problem from the practical sphere to work it out more accurately. Aristotle got entirely away from practical interests. Thus the artisan and the philosopher who had been held together by Socrates were separated. Plato concluded that the artisan could never know the social values of his activity, and, therefore, could never become truly moral. The philosopher was to know the supreme good and transmute it to the warrior and citizen class which would be able to appreciate it when it should be shown to them, though they were unable to discover it for themselves. The industrial class could not appreciate the supreme good at all; hence they should simply follow the directions of the citizen-warrior class as received by the latter from philosophers. ${ }^{x}$ Socrates had never taught that the man who was pursuing particular ends could not become wise and thus realize the end also. What he insisted upon was that the social values of all the minor ends, all the particular activities, should be appreciated. Only thus could a man become truly moral. But in taking this position Socrates

I Dewey, ibid.; Wundt, Ethical Systems, I5, 16; Sidgwick, op. cit., 40-46; Plato, Republic, ix, 320, $32 \mathrm{r}$.

"Philosophy has now passed from the market-place into the study or lectureroom. The quest of Socrates was for the true art of conduct for an ordinary member of the human society, a man living a practical life among his fellows. But if the objects of abstract thought constitute the real world, of which this world of individual things is but a shadow, it is plain that the highest, most real life must lie in the former region and not in the latter. . . . . It is plain that if the good that is to be known is the ultimate ground of the whole of things, so that the knowledge of it includes all other knowledge, it is only attainable by a select and carefully trained few."-Sidgwick, loc. cit. 
had implied the position taken afterward by Plato. He had taught that only the wise man could realize the end of life. To Plato it became apparent that only a few could become wise. Therefore the ideal state should be guided by the philosophers who alone knew the supreme end. The warrior-citizen class could be useful only as they followed the directions of the ruling philosophers in attending to the details of administration and in defending the state against enemies. The industrial class had to remain entirely servile. The activity of this class was essential to the welfare of the state, but the activity itself was base and by itself meaningless.

Thus Plato got entirely away from the individual whom Socrates addressed, and laid the emphasis upon the political organization. His ethical ideal lay, not in the well-being of the individual, but in the ethical perfection of the species. The ethical ideal became the political, and "in the midst of the time which saw the dissolution of Greek political life, and in opposition to those doctrines which proclaimed only the principle of individual happiness, he raised the conception of the state to an all-controlling height."

It was not reasonable to restrict all virtue to the wise alone; so each of the social classes in pursuing its proper activities would cultivate its proper virtue: the artisan moderation, the warrior valor, the teacher wisdom. The unity of these virtues could be found only in the highest class, the philosophers. These would necessarily combine in themselves the lower virtues; ${ }^{2}$ but the unity of the virtues was not to consist in their identity, as had been assumed, but in the government of the lower by the highest. The functional unity of these virtues is found in the harmonizing of them all, in the social virtue, justice $(\delta \iota \kappa a \iota \sigma \sigma v v \eta){ }^{3}$ This fourth virtue stands most closely connected with the particular virtue of the philosopher. The wise man is one in whom the various elements are operating in harmonious activity; and this

I Windelband, History of Philosophy, I26.

2 Plato, Republic, ix, 319, 320.

3 Wundt, op. cit., 16. 
activity cannot be perfect unless the man is truly wise. ${ }^{x}$ And yet

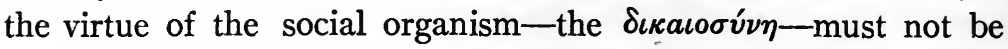
confounded with the virtue of the philosopher class which realizes the social end. There is no assertion, as in Christianity, of an identity of interests between the individual and society. Socrates had sought to solve the opposition between the individual and society; but Plato was content to have it remain. No one in the Platonic state could pursue his own ends. Even the philosopher simply directed the state for fear of the evil results which would follow his neglect. His real interest was in contemplation. But in addition to seeking his own good, he had to seek the good of society as a whole. This was a violation of the organic.principle which Plato was seeking to apply. If there was a common or social good, it ought to be the good of all classes. Each class was in some sense an organ of society; but the end of the social organism was not the end of any one of the classes. The artisans had to work in order to maintain society; the warriors had to fight in order to protect society; the philosophers could perform their function only when the other classes were performing theirs. The philosophers in contemplating the good would serve the ends of society at the same time that they served their own; but in addition to this they had to perform a social service in which they had no individual interest, namely, harmonize the activities of all three classes.

We find in this ideal Platonic state the principles underlying the political organization abstracted from any particular form of political organization. The same general cause led to this development, which among the Hebrews led to the movements already traced, namely, the disruption of the established social habits. When these could no longer function as in earlier times, the individual had to be thrown forward as the means by which a new co-ordination should finally be secured. Among the $\mathrm{He}$ brews, as we have seen, it was held that the individual who was willing to obey the divine will could realize his ethical life under any external conditions whatsoever. Among the Greeks, both

× Sidgwick, op. cit., 45 . 
the Sophists and Socrates held that the individual who attained to knowledge of the good could realize his ethical life amidst the chaos of the decadent Hellenic society. Among the Hebrews, as finally stated by Jesus, the individual needed an ideal society in which to function, a society in which the interests of the individual and the interests of the whole should be identical. Because the emphasis was laid on the willingness, the ideal society could be democratic, since any man could be willing to observe the divine order. Among the Greeks, on the other hand, the man who was to realize an ethical existence had to have an insight into the supreme end of life. Socrates rather hoped that every man might attain to this insight; but Plato was obliged to give up this hope. And although an emphasis was given to the individual in some of the later Greek systems, it became more and more apparent that only the select few could ever attain to the insight which could enable them to appreciate the ethical end of life. The movement had to become aristocratic. And so, when the new social order was posited by Plato, the wise had to be made rulers. All others could come to their ethical life only through these. The interests of the masses of humanity were not identical with the interests of the whole society. Therefore the minor interests had to be co-ordinated-or, better, coercedby those who understood the supreme end. To anticipate a little, this is what actually took place when the Greek theories were practically applied by the Romans. Both the Hebrew and the Greek systems were formal; but since the Greeks had worked out certain intellectual conceptions of the social order, they could go on manipulating these; while the Hebrews could never get beyond the purely formal statement until they took up the intellectual framework furnished by the Greeks.

The inadequacy of Plato's conception of governing and governed lay in the fact that he did not recognize that the standards by which he would guide action had been worked out in the social process itself. It was possible to formulate the new art of control of both individual and social life only because of the particular arts which had already been developed. Plato assumed 
a standard to be given to action to guide it. Yet this assumption would have been impossible, had not the Greek consciousness been saturated with the art conceptions. The artisans had been working according to standards so long that Plato took them as a matter of course. ${ }^{x}$ But these standards had been worked out in the industrial processes themselves. Only in the same way could social standards be obtained.

We have seen that the nature of the Greek development led to the severing of the meaning from the existence and the finding of the value in the meaning rather than the existence. The technical development had necessitated this. The art consciousness meant the appreciation of the ideal element which was yet immediately objectified in type form. Now the Greek ethical development followed the same course. The principles of conduct were abstracted, and yet the ethical ideal was conceived as an objective reality, not as a construction arising out of the activity itself. The universal was abstracted from the particularswhether material objects or specific cases of conduct-and then the particulars were neglected as interfering with the appreciation of the universal. But this universal, or ideal, was immediately objectified either in some type form of art or as an ethical standard. The ideal became the reality. In ethical philosophy a fixed ideal.was set up, and the activity was regarded simply as a means of reaching the goal. This was the essence of the Greek movement, especially as exemplified in Plato. The goal was fixed, and no progress was looked for beyond that goal. The social life was regarded as static. No principle could be laid down on which society could be constructed. The Republic gave a system within which the philosopher was to control, but did not show how the philosopher was to control.

Now, in reality, the standards used by all classes in the arts and crafts had been developed through the particular activities which were guided by them. So also the ethical standards which could now be used in the guidance of conduct had been developed through the life process itself. If Plato had seen that con-

× Dewey, ibid. 
sciousness in its own development had evolved these standards, he might have been willing to trust the process of life to realize the standards of life, instead of setting up a philosophical class apart from the life-activities to declare the standards. The philosophers could be the mediators of the practical social life only in the sense that they might interpret and generalize it from within society. They could never stand outside of society and invent by pure reason the standards of life for society. The standards were themselves a part of the process, and all that philosophers could do was to generalize them. ${ }^{x}$

The consequence of the system has already been indicated. The Platonic society was statical. No possibility of progress was recognized. It was also a mechanical aristocracy. Only the philosophers could know the social end. When they should declare the fixed ideal all other classes must be compelled to conform to it. When the practical administrative ability of the Romans took hold of the ideas, the Roman Empire was the result.

Little need be said in this connection of the movements after Plato. Aristotle was still more interested in the theoretical side of the problem, and was more willing to allow practical conditions to continue as they were. He formulated the metaphysics and the logic so that they could run on independent of the social life, while the social life could run on by itself undisturbed by philosophy. Socrates had stood for the immediate application of thought to life by every individual for himself. Plato also held that thought is the instrument of action, but further held that it is first necessary to know what thought is. The philosopher was to think that others might act. Plato was still trying to hold the social life together. Thought was still but an instrument of action; and the philosophers were called in simply because every individual could not work out his own end. The dualism was complete in Aristotle who made thought, which was formerly the means, an end in itself. Philosophy was no longer a mere instrument to be used in furthering life. This position enabled Aristotle to separate logic, rhetoric, politics, etc., as his predeces-

Dewey, ibid. 
sors never could do. ${ }^{x}$ The Socratic movement is, perhaps, best observed in Plato, since he formulated what his master left inchoate, and yet did not lose sight of the importance of applying his principles to the social life as Aristotle did. But Aristotle worked out the intellectual categories which were used by later society in measuring the values of life. These were but the systematization and formulation of the judgments concerning society reached by his two predecessors. The Church had to turn to these for the intellectual framework of the Christian dogmas. "The fundamental part of the scientific conceptions and expressions everywhere in use, even to the present time, goes back to his formulations."2 The cardinal points in previous speculation gained in distinctness from the application of Aristotelian analysis, and the development was carried further on the more abstract side. Plato had only incidentally applied his analysis of the social processes to the universe as a whole. Aristotle went on from that point and formulated the conception of a world cause. The old animistic conceptions were completely generalized, and the idea of a soul of the universe, a rational logos, was attained. This was the monotheistic conception of the world which passed into Christian doctrine. The Hebrew monotheism was ethical, not intellectual. One God was held for purposes of obedience and worship. The Greek monotheism was intellectual, and supplied the deficiencies of the Hebrew system when the latter passed into Christian doctrine. ${ }^{3}$

Of the post-Aristotelian movements still less need be said in this connection. The social disintegration had proceeded so far that the interest was centered in the conduct of the individual life. The essence of the moral life was found in the individual. The finding of reality in the universal, rendering the particular an obstruction, led to an emphasis upon the contemplative life. The importance attached to the reason, and the dualism between it and desire led to efforts to secure the individual the benefits of

I Dewey, ibid.

2 Windelband, History of Philosophy, 139.

3 Dewey, ibid. 
the rational element. The Stoics held that reason could deny that an object was desirable, and thus throw it out of the range of the desires. The Epicureans held that the reason could analyze the objects which arouse the desires in order to save the latter from illusion. The Neo-Platonists held that reason became ecstatic, passionate, engrossing the individual so completely as to cut him off from the lower part of his nature. This last position was reached by blending Greek and Hebrew thought. The emotional value given to the reason became of considerable importance in the earlier Christian movement.

Philosophy realized its inability to fulfil the task it had set: the education of man by sure insight to a state of virtue and happiness. $^{x}$ The Christian religion seemed to satisfy this want. But so strong was the feeling of a need of knowledge that religion had to attempt to satisfy both the intellect and the emotions, and had to transform its life into a doctrine.

The true, victorious power of the religion of Jesus lay, to be sure, in the fact that it entered this decrepit, blasé world with the youthful force of a pure, high, religious feeling, and a conviction that was courageous to the death; but it was able to conquer the ancient civilized world only by taking it up into itself and working it over; and as in its external conflict with the old world it shaped its own constitution and thereby ultimately became so strong as to be able to take possession of the Roman state, so also in its defense against the ancient philosophy it made the world of that philosophy's ideas its own, in order thereby to build up its own dogmatic system. ${ }^{2}$

The Hellenistic efforts to attain to a new religion which would take the place of the old religions that had been destroyed failed of direct realization. But

on the other hand, the need felt by positive religion to complete and strengthen itself in a scientific doctrine did attain its goal; the Church created its dogma. And the great course of history in this movement was, that the defeated Hellenism in its powerful death-struggle still created the conceptions by means of which the new religion shaped itself into a dogma. ${ }^{3}$

The effect of Greek thought upon the Roman movement was no less marked than its effect upon the Hebrew. The Platonic

I Windelband, op. cit., 2 ro.

2 Ibid., 212.

3 Ibid., 215 . 
conception of the state as freed from ethnic limitations and compelling all classes to serve its ends, and the Stoic conception of a natural law as divine and eternal and above the particular laws of any community, gave the intellectual tools by which the practical genius of the Romans was able to work out the constitution of the world-empire and a body of law for all nations.

Thus the contribution of the Greeks to civilization consisted in bringing to consciousness the part played by the intellect. As the Hebrews emphasized the moral motive, so the Greeks emphasized the standards by which moral conduct may be measured. As the Hebrews tended to formulate experience in subjective terms, so the Greeks tended to formulate experience in objective terms. In generalizing experience and giving the generalization typical form, the Greeks made possible the conception of standards by which experience could be judged; and by abstracting the principles underlying social organization, they made possible a rational conception of social relations. The bearing of the Greek contribution will appear more clearly when related to the Roman as well as the Hebrew.

\section{THE CONTRIBUTION OF ROME}

Our examination of the Roman development will require less time than we have been compelled to devote to the two preceding societies, not because the mass of information concerning the Romans is less than that obtainable concerning the others, but because the most important contribution of the Romans was in part the outgrowth of the Greek development, while much of the Roman social life developed according to principles that have been set forth in the earlier portions of this essay. The practical organizing ability of the Romans enabled them to accomplish what the Greeks could not, and yet the Romans would doubtless have failed, had not the Greek contribution been made available for them at the time when they were reconstructing their social organization.

The earlier social organization.-The early Roman organization did not differ materially from that of many other peoples. 
The family organization did not break down at an early period, as had happened among the Greeks. The patriarchal family was continued. The family was a social organ, the father having responsibilities in return for the powers that were vested in him. The worship of shades was the basis of the maintenance of the family continuity, for only where there is something approaching the patriarchal family can this practice have the significance that it had among the Romans. ${ }^{x}$ So this was not simply an act of piety; it was a political duty. ${ }^{2}$ The clan system was also maintained in connection with the institution of the patriarchal family, and was made of political importance. ${ }^{3}$

The religion of the Romans likewise became a means of political control. Like the religions of the East, it represented the consecration of political and social institutions; but whereas the oriental religious rites tended to swallow up the institutions which they first arose to protect, the Romans made the religious organs subservient to the political institutions and used them only to strengthen the institutions in the minds of the masses of the people. When the early Greek religion became inadequate, its substance passed over into philosophy. The Roman religion did not break down in the same sense; for the Romans early began to work over their religious ideas into political conceptions. They were never interested in nature as nature, but held down nature to practical purposes. The Roman gods watched over the habits of life. Every important social act had its particular divinity. When another people was taken into the Roman state, its gods were naturally taken in also, and thus the Romans became successful in organizing other peoples.

Perhaps the peculiar development of the Roman religion was due to the constant conflict of the people with their neighbors, against whom they were yet able to maintain their integrity. The Greeks were able to lose the sense of value of their outgrown institutions; but the Romans never felt safe in changing the social

I Cf. Twelve Tables, xi, 3, 15.

2 Ibid., iv, I, 3, 4, 5 .

3 Ibid., v, 2, 6. 
habits which had worked well in the past, because they were always under pressure from without. They therefore clung to and reconsecrated their political institutions, even when they were gradually widening their significance. The growing control of the wealthy classes tended to make the religious institutions more and more important as agencies of political control.

All legal procedures and formulas were religious in character. The forms of procedure connected with all the important events of life were connected with religious ceremonies. These forms were held in the possession of the ruling classes until several revolutions had taken place. Until the conquests had proceeded quite far, Roman law was not more noteworthy than any other barbaric law. It was simply a body of ceremonial rules which were held a sacerdotal secret. With the increase of the importance of the plebeians the narrow system was broken down, and the law of the Twelve Tables was prepared about $45^{\circ}$ B. C. All subsequent development proceeded from this code.

The use of omens was likewise for political purposes. Omens could not be controlled by private action. Diviners were a political class, and the omens could be inspected only with reference to public ends. ${ }^{x}$ After the beginning of ethical individualism there was a tendency on the part of individuals to resort to omens for their own purposes; but when the state was in vigor this was forbidden.

The subservience of all to the political power was thought necessary in order to maintain a balance of the interests of all. The Romans laid a tremendous emphasis upon private rights; but, on the other hand, the state was regarded as a necessary means to secure the rights of the individual. The peculiar feature was the appeal to self-interest; and self-interest could be secured only through the state. So the state was both extremely autocratic and extremely democratic. ${ }^{2}$ This feature of Roman life was developed, largely at least, by the expansion of the state and the demands made upon the administrative system. The expansion

I Twelve Tables, xi, 2, 6.

Dewey, ibid. 
was so rapid and the works and the public domain were so vast that individual enterprise had to be depended upon for practically all administrative purposes. When the Empire was established, administrative methods had been so far reduced to a system that public officials could manage public affairs with less abuse than was found unavoidable under the contract system. But in the earlier days it had seemed necessary to put up at auction the duties of collecting rents from the public domain, of fitting out ships and provisioning armies, of constructing roads, aqueducts, and other public works. Thus public ends were best served by private enterprise. This led to a greater recognition of the rights of the individual, which the preservation of the patriarchal family had already made greater than among any other ancient people, and to the further emphasis of the idea of private property which had likewise received marked development under the influence of the family institutions. But since the great enterprises which gave scope for individual activity were public enterprises, the individual was bound to the community in the strongest possible way. So a powerful appeal could be made to the individual, and yet the individual could be used as an agent.

Like Roman law, Roman government was not unlike that of any other city-state until the extension of the empire. The Roman life differed from that of any Greek city in this: Rome was isolated, while there were many Greek cities in constant intercourse with one another and with ancient civilizations. 'The earlier intercourse of Rome with her Latin neighbors was only such as would arise in a struggle for existence with them; and when the Latins united their forces for self-defense, they had little to give one another: they had not yet reached the stage where each community could contribute to the others, nor did they have the religious gatherings which would promote an exchange of the results of their various lines of development. Rome had no intercourse with the Egyptians and Assyrians; little with the Phœnicians. The Etruscan influence was probably too early to be of service to the rude Romans, except in architecture 
and the laying out of the city strongholds. The Greeks had been kept by their rivalries from developing any such concentrated political power as that enjoyed by Rome. The Greek nation consisted of a number of rival states; the Romans formed a concentrated national state with an organization based on the administrative system of a single city. The struggle for existence was so severe that by the time they had conquered security war had come to have an æsthetic value for them, and so was carried on for its own sake. Their great end became war, though at the beginning their wars had economic causes or were carried on in self-defense. Among the Greeks the multifarious demands of society had brought many civil virtues into prominence. War for the Greeks was simply a means of securing some definite object. A state of peace was with them the natural state of mankind. War for the Romans was a permanent occupation. So, most naturally, the Romans came to have both a superior military organization and more intense national feelings. The Roman considered himself but a component part of his nation, and viewed Rome as placed over against all the rest of the world. ${ }^{x}$

The expansion of Rome.-The Roman political constitution, like that of the Greeks, fell to pieces under the stress of new conditions. But Rome never went through what she would acknowledge to be a revolution. As indicated above, the constant pressure of external enemies made necessary a stable constitution; and the unassailable strength of the ruling classes and landlords -never overthrown, as at Athens, by the rapid rise of the industrial classes-permitted internal changes only by gradual stages. Practical necessities led to minute alterations from time to time, until the revolution was accomplished. The establishment of the republic meant little more than the change from a life-archon to annual archons and from a single ruler to two who might check one another.

From the establishment of the republic (509 B. C.) to the end of the second Punic War (20I B. c.), the senate, composed of the aristocracy, was the real government of Rome. Though but a

I Findlay, Greece under the Romans, 20, 21. 
consultative body, the senate, like all legislatures, was able to make constant inroads on the executive; and had in this case particular advantages because the magistrates were elected for but a year, and were usually drawn from the classes strongest in the senate. The popular assemblies were seldom held, being called only when the magistrates summoned them.

While the senate, however, was thus profiting by knowing its own mind and by having functions too indefinite to be curtailed, the conquests of the Roman armies, which the senate at first did so much to advance by supplying both wise plans and effective leaders, were sweeping together an empire whose government was to prove an impossible task even for the senatefor any magistrate or assembly, indeed, known to the constitution of the city-republic. Rome was denied the exclusively municipal life for which her forms of government fitted her and which was permitted to Athens, Sparta, and the other cities snugly ensconced in their little valley nests among the mountains of Greece. She had no pent-up Attica in which to live a separate life. There were rival towns all about her on the plains of Latium and beyond the Tiber in Etruria. When they had been brought under her supremacy, she had but gained new hostile neighbors, to whom her territory was equally open. She seemed compelled for the sake of her own peace to conquer all Italy. Italy subdued, she found herself separated by only a narrow strait from Sicily. Drawn into the tempting island by policy and ambition, she came face to face with Carthage. In subduing Carthage she was led to conquer Spain. She had been caught in a tremendous drift of compelling fortune. Not until she had circled the Mediterranean with her conquests, and had sent her armies deep into the three continents that touch its international waters, did she pause in the momentous undertaking of bringing the whole world to the feet of a single city. And her constitutional life itself felt every stroke of these conquests. This constant stress of war was of the deepest consequence to her politics. ${ }^{x}$

It soon became impossible to administer the vast empire by means of a municipal constitution.

And yet no new system seemed possible to the Romans. They simply attempted to extend their city constitution over the whole world. The consuls and prætors of the city were simply extended as proconsuls and proprætors of the provinces. But in the provinces these officials became almost wholly irresponsible. No way could be conceived by which a local government might

I Wilson, The State, 99, 100. 
work in harmony with the general government. The provincials could not be enabled to check the rapacity of the Roman governors and contractors without having a part in the government; but this could not be, since the Roman system knew nothing of representative assemblies and consequently nothing of citizenship outside of Rome. The governors had but short terms of office, and could understand but little of the ultimate needs of their provinces. The temptation to join the capitalist contractors in exploiting the provincials was very great; and when they attempted to introduce reforms, the influence of the capitalists in Rome was sufficient to secure their disgrace and the appointment of worse men in their place. ${ }^{x}$ The problem was finally solved, not by raising the provincials to a real citizenship, but by bringing Rome to the level of the provinces by overthrowing the constitution and giving her a master like those of the provinces. Under the consuls the provinces had been administered as the property of Rome; under the emperors they were administered as integral parts of Rome.

These changes were made gradually. The transition period extended from the beginning of the agrarian movement of Tiberius Gracchus (I33 B. C.) to the death of Augustus (I4 A. D.). The movement of the Gracchi was futile because the ruin of the free yeomanry was already complete. When foreign grain poured into Italy, not even the extensive cultivation of the vast estates by armies of slaves could be kept up; and so these estates were converted into pasture lands. Further, there were no longer many free peasants to be rescued. They had laid down their lives on thousands of foreign battlefields. The oligarchy, dissolute from long-continued power and prosperity, no longer checked by a numerous population of free Romans, fell into countless factional conflicts, until Cæsar came back with his victorious army and assumed control. By the end of the long reign of Augustus, the emperor had become the state personified. Every legislative and executive function was vested in him, and the magistrates became his personal representatives. His household officials

x Plutarch, Lucullus, vii, xx. 
took the place of the private contractors and irresponsible governors, and the system of administration employed was the admirable one which the Romans had worked out in the management of their private estates. Since the whole empire had become the private estate of the emperor, it would have seemed intolerable to continue the old system of irresponsible administration which had permitted speculators to exploit the provinces. The emperors began to look upon the empire as a whole, and that whole was larger than Rome. They could not but take as much interest in the prosperity of some of their fairest provinces as they took in Rome itself. This was especially true when the emperors, beginning with Trajan, were most frequently themselves provincials. Finally, after all freemen had come to possess equal privileges, or rather to bear equal burdens, Caracalla's universal enfranchisement was but the recognition of an accomplished fact. The universal state was for the first time realized. The "framework was put together for the organization of widespread peoples under a single government. Ancient politics were shading rapidly off into modern." $\quad$ The community now went beyond religious, family, and tribal relationships. All individuals and all tribes could now be included within a single community; and this community, directed by the emperor, could pursue its own ends. Each member of the empire had his place. He need not comprehend the ends of the state. If he performed his own functions, whether as government official, member of a trading corporation, or member of an artisans' college, the ends of the state would be achieved. The perfection of the administrative machinery would assure that.

The Platonic ideal was thus realized, but the emperor took the place of the philosopher. As in the Platonic state, no man's particular activity could be regarded as realizing the actual values of life. The social good could be attained by the state, it mattered not whether even the philosopher could know that good. The various classes should perform their proper functions, and the state would secure the co-ordination of them all. No individual

I Wilson, op. cit., 127 . 
needed the virtue of $\delta \iota \kappa a \iota \sigma v i \nu \eta$. As with the Greeks, the universal end was all-important. The particular ends were not regarded as functionally related to this end. They were too likely to appear to conflict with it; and, indeed, it was this conflict between the irresponsible, individualistic activities of so many Roman capitalists and speculators that had resulted in the downfall of the republic. The co-ordination was to be secured in a mechanical way-by force, if necessary. But while the Greeks could not organize the means for securing the universal end by coercing all individuals, the Romans, with their great arranging and ordering capacity developed through long military and administrative experience, formulated a system by which all individuals could be overruled and brought into harmony with the assumed ends of society. The empire did not exist to help a single individual to realize the values of his life; it had an ethical end of its own to which all individual interests should be subservient. If the emperor could be an arbitrary despot, it was only because he was the state personified.

How far the Roman political organization was influenced by Greek speculative political philosophy can not be stated with certainty. It is certain, however, that from their first contact with the Greeks the Romans had been saturated with Greek thought. The struggle to prevent an inundation of Greek philosophers in r6r B. c. is an indication that Hellenic influence had already become so great as to be feared by the more conservative classes. By the time of Cicero and Cæsar everybody wanted to learn of the Greeks. At such a critical period, when the constitution was being broken down and a new one formed, the Romans were in a good position to give practical application to the political conceptions of the Greeks. The influence of Greek philosophy in the development of Roman law which was going on at the same time makes probable the conclusion that the correspondence of the Roman political development to the Greek ideal was more than a mere coincidence. Without the conception of social organization furnished by the Greek philosophers it is possible that the Roman political development would have 
been so long delayed as to be too late to serve its practical purpose; just as a development of the technical processes from the bottom by the Greeks would doubtless have rendered their high artistic attainments impossible.

The Roman Empire, then, may be regarded as the embodiment of Greek political conceptions, rendered necessary by the gathering-together of all the nations of the world and the attempt to hold them all in one political community. The conception of the state which had come from the Socratic period would have been valueless but for the administrative capacity of the Romans. The Romans were not interested in further reflection on the organization of the state. In their whole history they never produced a philosopher whose contributions are worth anything for the development of thought. They needed only sufficient thought to start them. Then, while the Greeks continued to work over their concepts and became mere controversialists, the Romans went on with the codification of laws and organization of the social habits, leaving reflection socially unconscious. The Romans did not solve the essential opposition between the individual and society which remained in Greek thought, but simply recognized society as a whole and compelled the individual to submit to the whole. The end having been set before them, they could turn their attention to the perfecting of a system of means. A solid social framework could thus be counted on to secure the ends, though there was always danger that it might become so rigid as to prevent further development.

The development of Roman law.--The development of Roman law was likewise determined by the exigencies arising from the extension of Roman rule to foreign peoples. Here, at least, the influence of Greek thought was unquestionably important. We have already seen that the first codification of the primitive practices was the basis of all later law. The Twelve Tables was for a long time the only law, except a small body of decrees of the senate and a few legal principles established by agitation. In applying these simple principles the prætor, consciously or unconsciously, became the source of new law. This body of law, 
the jus civile, was applicable to Roman citizens only, it having been inconceivable that a foreigner should have a part in the sacred Roman customs. But with the growth of intercourse with foreigners, it became necessary to have established processes for cases arising between two aliens or between an alien and a Roman citizen. The precedents established in these equity cases before the prætor of the foreigners became the jus gentium. With the extension of the empire the latter law became the more important. The subject localities were permitted to retain their local institutions; but cases arising between natives of the province and Roman citizens, or between natives of two different provinces or even two different localities of the same province, had to be judged by the jus gentium, and the Roman governor had to exercise the function of the prcetor perigrinus. Thus a great body of miscellaneous precedents strongly impregnated with Roman legal principles was developed. And this body of law came to be regarded as more natural and more equitable than the jus civile.

The increasing complexity of the relations between the residents of the different sections of the empire naturally led to an examination of the jus gentium by lawyers and to the use of its leading principles in the interpretation of Roman law in general. At this point the Roman lawyers were assisted by the conceptions borrowed from the Greeks, and especially from the Stoics. The Stoics were setting forth the idea of a world-citizenship corresponding to their conception of an ethical community of all men. Their interest was only in a remote degree political. Primarily they looked for a spiritual and ethical universal empire. ${ }^{x}$ The law which the Stoics would apply in their cosmopolitan community should be a law of nature, as opposed to the artificial laws then prevailing in the particular states. This law was to be binding upon a man as a rational being and a member of the universal community of rational beings. It was to embody the divine Reason and would be superior in validity to the mechanical laws framed by particular human societies. To the Romans, feeling as they were for a universal law for their universal empire, this law of na-

I Windelband, op. cit., I75-77. 
ture was the very thing needed. They recognized it in the jus gentium, a body of law not sprung from the choice of individual men but apparently inhering in the very nature of things. This conception of a natural law was given currency by Cicero, and following him there arose philosophical lawyers who sought out the common principles of the equity courts throughout the empire, which they recognized as the law of nature. ${ }^{\mathrm{x}}$

Probably, it seemed, these conceptions of justice which the foreign protors had found common to the thought of all the peoples with whom they had come into contact were manifestations of a natural, universal law of reason, a law of nature superior to all systems contrived by men, implanted as a principle of life in all hearts. The jus gentium thus received a peculiar sanction and took on a dignity and importance such as it had never had so long as it was merely a body of empirical generalizations. Its supremacy was now assured. The jus civile more and more yielded to its influences, and more and more rapidly the two systems of law tended to become but one. ${ }^{2}$

With the disappearance of Roman citizenship, or rather with its universalization, the jus civile necessarily disappeared, and the jus gentium, reduced to some order, became Roman law. Thus by the union of the practical codes of the Romans and the formative legal conceptions of the Greeks, Roman legal principles, which had originally been developed in their local application, were universalized.

The development beyond this point was only a matter of amplification and arrangement. This great theoretical development was given the law chiefly by private jurists. The opinions of these great lawyers soon came to be recognized as of greater authority than the decisions of the courts. This development by commentators went on from the time of Cicero until about 250 A.D. After the opinions of the jurisconsults had been recognized by custom for some time, and no other great lawyers arose to further expand the law, the emperors gave legal sanction to them. In addition to these important legal opinions, the senatus consulta and the im. perial constitutiones entered into the body of the law. The shaping forces, however, were found in the opinions of the jurisconsults.

× Windelband, op. cit., I77; Sidgwick, op. cit., 97, 98; Wilson, op. cit., I36.

2 Wilson, op. cit., 137 . 
Naturally, the difficulty of harmonizing conflicting opinions and of choosing the real authorities in the great mass of law thus developed became greater and greater as time passed. Hence, after the legal principles had been worked out thoroughly, the demand arose for codification. This demand was an evidence of the decay of the Roman state; for during the period of vigor and expansion of institutional life, codification was impossible, and was probably never thought of. The Theodosian code of the latter part of the fourth century of our era was of considerable importance because of its influence on the earlier legislation of the Teutonic rulers. But the great codification was, of course, that made by Trebonian at the command of Justinian (534 A. D.). This gave Roman law its permanent shape and served as the basis for the new study of Roman law by the men of the Middle Ages. By the fourth century, A. D., the old republican legislation, the prætorial edicts, and the imperial constitutions had been almost completely fused by the jurists. The distinction between the jus civile and the jus gentium was by that time entirely obliterated. In the Justinian code the imperial constitutions and all other legislative acts became the Codex, the work of the philosophical lawyers became the Pandects, the summary statement of the whole was known as the Institutions, and the special decrees issued to fill gaps and clear the whole of inconsistencies were codified as the Novels. The whole was the Corpus juris civilis. This constituted the definite legal contribution of the Romans, made possible only when their empire was passing away.

The contribution of the Romans was thus the framework of the institutional life of society. What the Greeks had stated as an ideal they practically realized, though in a cruder form- a universal society and a universal law. But the social organization had been too far perfected before the consummation of Hebrew life for the Hebrew element to be blended with the others in the constitution of the empire. Like the Greeks and the Hebrews, the Romans perfected their organization and their law, and brought them to consciousness, only when the Roman life was about to pass way. 
It is a commonplace that modern society has received something from each of the three ancient societies we have been studying; but the nature of that inheritance is seldom fully realized. When the Teutonic peoples came in contact with civilization, they found, for the first time in the history of the race, that the ideas which underlay the structure of human society had been abstracted. Primitive social life consists in the development of well-adapted habits in a relatively stable environment. For reasons already given, these habits of the Hebrew, Greek, and Roman peoples disintegrated, and new co-ordinations had to be attempted. As a result of the previous development and the peculiarities of their respective environments, a different outcome was reached in each of the three cases. As a result of reflection upon their decaying life, the Hebrews were able to free the ethical impulse from the old social habits, while the Greeks freed the idea of the end of life from the particular life-activities.

The Hebrews threw an emphasis upon the value of the individual, because every part of experience had the Absolute in it and every person who was willing to live the moral life could realize the Absolute in himself. And since every part of experience was backed by the absolute principle, the individual was given a moral emancipation from all the trammels of the existing evil world. But the correlative of this doctrine was also stated as an essential part of the Christian program: the individual could be fully conscious of his own value only in a society in which others could realize the value of their existence. The essential identity of the interests of the individual and the interests of the whole was asserted in the doctrine of the kingdom. This was not the assertion of an identity which already existed, but of one which ought to exist. The ideal community could not be stated in specific terms; so the Christians had to fall back on love as the motive to the common life. The individual could be stated only in emotional terms, because the society of which he was to be an organ did not exist. The intellectual definition of an 
individual can be made only in terms of the society which actually functions through him. In the time of the early Christians, society was so marked by its defects that it could not be accepted as the real community. The individual's duties could not be determined by the social life about him. So the motive had to be trusted to work itself out in the formation of an actual society in which the interests of the individual and of the whole would be identical.

That which was abstracted by the Greeks was the end of the old social habits rather than their motive. They reached the conception of an absolute good which society as a whole was pursuing. This was the essential principle in the conception of the state. Along with this conception was that of the free reason as capable of knowing the end and thus realizing it. This cutting-loose of the values of the social life from the conditions under which they had been worked out by earlier peoples gave the world standards which, on the one hand, could be used in the development of Christian doctrine, and, on the other, could serve as the basis of the Roman Empire. It was in the form of Christian doctrine and the organized state that the Greek contribution could be appropriated by the Teutons.

As we have seen, the Romans gave the objective expression of the Greek idea of a society in which the common ends should be served by all. The importance for modern society of the Roman political system is not so much that it worked in the practical administration of the empire as that it served as a guide for the organization of Europe. From the nature of the case, the Hebrew and Greek nations had to perish in making their contributions; but the Romans could work out and enjoy their achievements for many centuries. But we can see that the empire had lost its vitality long before its fall, and that it was only as an ideal political system that it could have much value for Europe. It failed to organize the freed impulse into new habits having higher social ends. Without the legal machinery of the Romans society would have fallen to pieces; but it was the Teutons, not the Romans, who finally organized the impulse for the attainment of the common values. One proof of this is found in the fact that the undis- 
turbed Græco-Roman Empire never succeeded in accomplishing this task. It was as a working model, chiefly as appropriated by the Church, that the institutional machinery of Rome could be of value in objectifying the community idea and organizing the social motive of love. And this contribution could be made only after the empire had passed away. 


\section{CHAPTER II}

\section{THE PROBLEM SET FOR MEDIÆVAL SOCIETY}

The real importance of the movements we have traced appears when we consider the influence of these contributions in the development of modern civilization. The inheritance from the past gave Europe an underlying unity which produced a common civilization in the midst of a diversity that would have broken ancient society into fragments, or would have led to a conquest by one group of all others. Civilization was no longer carried forward by a succession of hostile nations; the civilization of the past molded the diverse and hostile groups into one society.

The mediæval period proper may be said to begin with Augustine on the reflective side and with the fall of Rome on the side of social organization. But all three of the movements we have considered had culminated long before that time; and for several centuries certain tendencies toward the fusion of their results may be noticed. The Greek development may be said to have been completed by the time Aristotle had finished his work (322 B. c.), though the Stoic and Neo-Platonic movements continued to extend the influence of Greek thought until Christianity gained the supremacy. The Hebrew development may be said to have been completed by the time the gospel was introduced into foreign lands, say by the end of Paul's life (66 A. D.), though the Christian movement did not secure its dogmatic statement and gain political recognition until the conversion of Constantine. The Roman development may be said to have been completed by the time the franchise was extended to all free inhabitants of the empire by Caracalla (2I2 A. D.), though the Empire of the West lingered on until the city of Rome fell into the hands of Odoacer in 476 , and the Justinian code was not completed until 534. During the centuries between the death of Jesus and the fall of Rome, the ideas underlying the three ancient civilizations were 
being blended in the thought of the Church and were receiving the shape in which they were to be handed over to the barbarians.

\section{CHRISTIAN DOCTRINE AND POLICY TO THE FALL OF ROME}

We have seen that Jesus asserted the ultimate value of the individual and the essential identity of the interests of the individual and of society. Yet this statement had to be formal; for the individual can be defined only in terms of his rights and duties in society, and the existing society did not make possible the identification of individual and social interests. Such content as could be given to the statement of the kingdom of heaven had to be in negative terms. The general statement of the new commandment as to loving enemies was set over against the old lex talionis, but what was involved in loving an enemy could not be stated. Such a statement would involve a complete program for social reconstruction, and that was manifestly impossible at the time. The Christian spirit could be inculcated, but its method of objectification could not be stated positively until the social transformation had itself taken place. It can not be too frequently reiterated that the individual can not be defined except in terms of his social functions, nor society except in terms of the co-ordination of individual activities.

At the very beginning, the importance of spreading the knowledge of Christian principles seemed so great that the gap between the formal statement of the ideal of the kingdom of heaven and its application to existing society was scarcely noticed. The disciples went everywhere preaching the gospel of the kingdom, telling of that ideal state in which every man is a son of God and every man so completely the brother of every other man that his own actions express the life of the whole community. But after this work had gone on for some time and many men had been gathered together under the influence of the motive of Christian love, it became necessary to define the manner in which the motive was to work itself out in the reconstruction of society. The first solution of the problem was one which simply postponed the necessity of obtaining a real content for the Christian prin- 
ciples; that is, it was found in the idea of the speedy return of Jesus. Since the King was soon to return to give detailed directions for the establishment of the kingdom, it was necessary, meanwhile, simply to prepare men to receive him. During this waiting period, it would be sufficient to abstain from those practices which were manifestly inconsistent with the Christian ideal. If the New Jerusalem was soon to come, it was unnecessary to find a positive content for the statement of the conception of the kingdom. While waiting for the coming of the Lord, Christians might live on in accordance with the practices of society, simply avoiding those acts which were plainly contradictory to the new ideal. Slaves were to remain slaves; family relations were to continue as before, though they were scarcely worth while; buying and selling might go on. ${ }^{x}$ So the positive content of the conception of the individual and his relation to society could no more be given by the Christian system than by the Greek and Roman systems.

Since no positive content was at once necessary, this reorganization of society on the basis of willingness to seek the welfare of brethren and to do the will of the Lord when he should return could go on in the consciousness of all men. Living in expectation of the new social system was possible for the masses. Yet Christianity had almost no power to reorganize Roman society. Beyond the expectancy of a new society, Christianity was as powerless as Roman society itself. It was in a newly developing society that Christianity could become an organizing power.

As time went on, however, it became necessary to give the Christian principles a more definite content. This necessity first arose from the extension of Christianity to the gentiles. Later, the fact that Jesus did not return created a still greater demand for a positive statement. Jesus had been directly interested only in the application of his universal principle within the particular community of the Hebrews. Except in the "Great Commission"-and the authenticity of that statement has been questioned by some biblical scholars-Jesus did not assert the universality of his principle of the kingdom. He turned aside

× Cf. I Cor., chap 7 
from opportunities to extend his kingdom beyond the "house of Israel," " though he was willing to deal with Samaritans. $\mathrm{He}$ asserted a truly universal principle, but did not abstract it from the particular. The Jerusalem Christians, although they felt that the old was done away, still sought to carry the content of the old Jewish organization into the new, while waiting in expectancy for the miraculous return of Jesus. The experience of the Pauline Christians caused them to raise the question whether the coming of the new had not already done away with the old. They saw what the consequence would be if they should attempt to compel the gentile converts to pass through the Jewish rites. During his conflict with the Petrine element, Paul passed successively to a more and more completely generalized position. $\mathrm{He}$ saw that it was impossible to extend the Christian conceptions to all men and yet make them conform to the Jewish practices. ${ }^{2}$ So, over against the concept of law-the ceremonial and moral practices which had to be conformed to by the righteous manwhich meant the continued moral supremacy of the Jews, Paul set up the concept of spirit. This, in effect, meant that the Absolute within the individual creates its own law.

Thus the generalization which had been made within a particular community became a true universal when it passed beyond that community. The particular society which had been interpreted by it was the Jewish society, the hope being entertained that its glaring faults could soon be removed. With the extension of Christianity, a new particular had to be defined. This was first done negatively: "There is neither Jew nor Greek, bond nor free." The belief in the speedy return of Jesus, held by the Pauline as well as by the Jerusalem Christians, still made it unnecessary to find a positive definition. Nevertheless, this Christian community was much broader than the Jewish-Christian community; and the missionary movement prepared the Christians for a positive statement of their position when it appeared that they could no longer look for the return of the Lord.

I Cf. Matt. 10:5-7; 14:21-28; etc.

2 Cf. the argument in the writings which belong to this period of Paul's activity, taken in the order of their appearance: I and II Corinthians, Galatians, Romans, 
When it finally became apparent that Jesus was not soon to return to earth, the Christians found it necessary to give their principles a more positive content. The mere preaching of the good tidings of the approach of the ideal kingdom lost its force. The positive content was secured, on the theological side, by absorbing the intellectual structure of the Greeks, and on the side of organization, by developing the Church on the model of the Roman Empire. On the theological side the development was the counterpart of the Greek logic. The concepts having been worked out by the Greeks, the Christian theologians could use them as the framework for the doctrines of Christianity. Beginning with Justin-and even before his time the Greek influence had been felt-a systematic attempt was made to adapt the Christian system to the Greek conceptions, in order to show that the former was the truest philosophy. Even the anti-rationalistic reaction of such men as Tertullian employed the philosophical method. From the time of Clement of Alexandria and Origen, in the first half of the third century, a positive system of Christian theology based on Greek philosophy was maintained.

This acceptance of Greek philosophy as the framework of Christian theology was most natural. Jewish Christianity had failed. There was nothing on which to build in the Jewish nation; and the Jewish-Christian community which survived after the universality of Christianity had asserted itself in the establishment of churches among the gentiles had no influence in the development of doctrine or organization. ${ }^{x}$ The doctrinal development took place under Greek influence. This was partly because Greek philosophy in later Platonism and Stoicism, and especially in its Alexandrian developments, was tending toward religion, and was therefore ready to embrace Christianity which seemed to meet so many of its demands. However, the assimilation of Christianity led rather to Gnosticism than to the forms of Christian doctrine which secured a permanent footing. It was by the Apologists-the conservatives who accepted the new

× Harnack, History of Dogma, I, 287-95. 
revelation as sufficient in itself for them-that the Jewish and Greek elements were most effectually blended. These men conceived of themselves as engaged in a conflict with Greek philosophy; but since Christianity had become detached from the Jewish world and was endeavoring to conquer the Græco-Roman world, they were compelled to couch their message in terms of Greek thought. ${ }^{1}$ Thus, to justify their faith, the Apologists began a movement which resulted in the formulation of Christian doctrine in terms of Greek philosophy.

For our present purpose, it is unnecessary to consider this development in detail. ${ }^{2}$ It is sufficient to note that a positive content was thus given to Christianity and a system of doctrines developed. But like the post-Aristotelian philosophers, the Greek Christians were content to become mere controversialists, leaving the executive side of life out of consideration. Having certain concepts given, they could go on manipulating these and perfecting their speculative doctrines without much reference to the social life. It should be remembered, however, that the social conditions were such that no other course was open to them, if they were to give Christianity any intellectual content whatever. Furthermore, it must be remembered that their discussions were not altogether fruitless for western Europe. After the doctrines had been pretty fully worked out and their controversies were becoming intolerable, the Roman Christians, who would never have worked out the doctrines for themselves took them from the Greeks, ignored the intellectual processes by which they had been attained, and turned them into dogmas, declaring that they had to be accepted as they were or the individual would be thrust outside the pale of salvation. Thus, a practical use was made of the theological development, an intellectual basis was given to the Christian system, and the vigorous, though narrow, doctrinal development of the Middle Ages was made possible. ${ }^{3}$

× Harnack, op. cit., I, 46-48.

2 For an account of the development of doctrine, vide Harnack, op. cit., II, I69 ff., etc.

3 Vide Hatch, Influence of Greek Ideas and Usages upon the Christian Church, passim; Windelband, op. cit., 210-62. 
Of more interest for our purpose, because in closer relation with social conditions, was the development of the Church. The principle of community of interests was expressed most clearly by Jesus in terms of the family relationship generalized to take in the whole community. But the smaller, simpler unit could not be substituted for the larger, more complex one. The brotherly relationship could be assumed only as an ideal. Its realization was possible only in emotional terms, that is, in a brotherly feeling, in a willingness to act in a fraternal manner, rather than in the activities of everyday social life. An emotional attitude was adopted toward others similar to the attitude of members of a family toward one another. Man could be a brother to every other man, not immediately through the activities of social life, but mediately through the emotional attitude which arose because of the recognition of a common sonship of God. ${ }^{x}$ The attempt to realize the brotherly relationship immediately in the exercise of social functions would inevitably have led to martyrdom, as it had done in the case of Jesus; but in the absorption of his consciousness in the Father of all the individual could realize himself as a member of the ideal community, the kingdom of heaven.

In its extreme form this attitude led to asceticism, where the individual was swallowed up in contemplation of God. This, of course, could happen only in a few individual instances, and could not happen at all until the mere proclamation of the good tidings could no longer hold the interest, and a more definite content had to be found for the new system. In the earlier stages of the Christian movement, and, indeed, with the masses at all times, the natural tendency was for men who had come to this consciousness of brotherhood to form a community within the society in which they lived. The Church represented a society within which the emotional generalization of brotherhood should pass over into one of action. It was a community within which the interests of the individual should be identical with the interests of the whole group. Preface.

I Mead. For an acknowledgment of my indebtedness, see statement in 
Jesus had demanded that men should live directly with reference to the law of the kingdom. He felt that the men who had been gathered about him were to make a moral conquest of the world; but he had no interest in the formation of an association which should be anything more than a company of people of like interests. He did not form a church. ${ }^{x}$ The members of the company of disciples were not to find their ethical completeness in any peculiar association, but were immediately to live out the principles he stated, even as he had done. That he hoped for the realization of the ideal social order in this world there can be no doubt. ${ }^{2}$ The earliest disciples came together spontaneously in a communistic association. This latter was an attempt at the construction of a society which should permit the Christian conduct of life. An actual rational society was to be substituted for one in which the community and the individual were in hopeless conflict. In that communistic society the generalization of the family relationship could be carried out into external relations. The conception of the Church as distinct from the natural society was not found in the earlier associations of disciples. That conception naturally arose from the distinction between the ideal society represented by the Christians and the larger society.

However, the formation of the Church did not give the Christians a complete society in which each individual could realize in actual life the brotherly relation. Most of them had to come into daily relations with the outside world. Family relations and daily business affairs made it impossible for the Christians wholly to confine their activities to the narrower community which they had formed. This difficulty was recognized even in

That is, he formed no association of a sacerdotal sort. His interest was in the kingdom, rather than the church; and that ideal association was to include the whole society to which the individual belonged. His two references to the ecclesia give no indication of an interest in such an association as that which has been developed in his name. Cf. Matt. 16:18; 18:17:

2 For a good statement of Jesus' conception of the ideal social order, with which in the main the above is in accord, vide Mathews, "Christian Sociology," II, American Journal of Sociology, I, 359-80. These articles have since appeared in book form. 


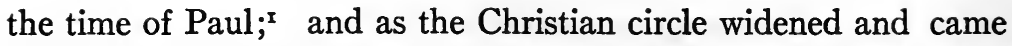
to include many less zealous individuals, it became more and more difficult to maintain a separate community. Since a smaller community in which the Christian motive could work itself out in activity was impossible, the Christians were thrown back again upon the emotional realization of the brotherhood of man. This attitude became even more necessary after hope of the Lord's speedy return was abandoned. With the abandonment of that hope, the speedy realization of the kingdom on earth became hopeless, and the New Jerusalem was transferred from this world to the next. The ideal kingdom could be realized in this world only in emotional terms. The solution of the social problem was found only in the individual emotional consciousness. To reach his brother in this world, the individual had to go, as it were, to heaven, and there find the lines of relationship with him in the fact of a common sonship.

Now it was only the high-strung emotional nature which could maintain this attitude continuously. The masses had to be absorbed in the ordinary activities of social life, however unideal those activities might be. Only the exceptional man could remain absorbed in contemplation of God and in reflection upon his sonship, the reflex of which gave him the recognition of the brotherhood of mankind. There thus arose a Christian aristocracy which was parallel with the Greek aristocracy. Although the movement of Jesus was extremely democratic, the fact that it was based on feelings which could not be objectified in social activity soon rendered it as aristocratic as the Greek intellectual movement had been. The saint was the counterpart of the philosopher. Naturally the Church adapted itself to the comparatively few men who were capable of the continued emotional consciousness of social relations. The ascetics maintained a more highly strung emotional state than any others and were therefore the greatest saints; but it was in this emotional realization of the kingdom that the priesthood also found its meaning. ${ }^{2}$

$\therefore$ Cf. Rom., chap. I4; I Cor., chaps. 7 and 8.

Mead, vide Preface. 
Everybody was not capable of this emotional realization of sonship. For the masses it had to be vicarious. It was sufficient if they came to catch occasional glimpses of the great ideal, and should recognize the importance of keeping it before the world. The masses had dropped, for the most part, into the ordinary round of social activities, and the ideal relationships could be held only in the consciousness of the exceptional men of the character described. As the Christian circle widened, a larger and larger proportion of the disciples became like the world about them, merely recognizing the ideal social order in its general outlines, and leaving to the select few the emotional realization of the kingdom which could enable them to keep alive the ideal until it could be realized in a different manner. The Christians therefore grouped themselves about the religious aristocracy composed of men who could come into this immediate relationship with God and into this mediate relationship with the human family, and who yet did not rise to the highest absorption in God which ignores the human family, as was the case with the ascetics. This aristocracy soon formed itself into a hierarchy modeled after the Roman administrative system. This social meaning of the priesthood is the explanation of the development of the Church. After the system was perfected and the priesthood had become a profession, many men who had none of the emotional characteristics described might enter it; but the social conditions continued to cause the masses to demand such an institution, even after the sincerity of many of the priests came to be doubted. In the West the administrative system constituted the chief content of the Christian principles, while in the East the doctrines constituted such a content; but the hierarchy originated in the East and had a very important place there, while the doctrines were likewise of great importance in the West.

This development was not only conditioned by the social situation; it was absolutely unavoidable if the Christian contribution was to remain in the world at all. The intellectual definition of the individual and society-for the two are correlativecould come only with the recognition of the social value of the 
essential functions of life. This was manifestly impossible in the Græco-Roman Empire. At that time the consciousness of the brotherly relationship with fellow-men, of the organic relations of all men in society, could be maintained only through the consciousness of sonship. The right social attitude could be maintained only on the side of feeling, and the true social relations could be defined only in emotional terms. The passing from this emotional definition to an intellectual definition constituted the development of the Middle Ages. When this transition was accomplished, the vicarious realization of the true social relations was no longer necessary, and so the Reformation became natural.

This development, however, belonged exclusively to the West. In the East, where conditions were fixed, it did not occur. The barbarians did not threaten the stability of society as they did in the West, and when they finally overthrew it, they were not assimilated by Christianity. The general social order could be counted on by the individual. Society was not likely to be swept away from around him. Nor, on the other hand, could he hope to change existing conditions and bring them into conformity with any ideal of the heavenly kingdom. The problem then became the ordering of life within a fixed society. This view was naturally strengthened when Christianity became the state religion. The possibility of social improvement was thereafter not recognized. The relation to existing society was that of toleration. Whatever higher ideals were cherished were regarded as incapable of realization in this world. Not only was the New Jerusalem pushed beyond this life; it was neither expected nor desired that anything approaching its counterpart should ever be found on earth. With the conversion of the emperor the toleration of existing conditions became acquiescence. The world as it stood could be counted on. The powers that be were ordained of God. They were not to be changed until the heavenly kingdom was entered. The religious life of the masses came to consist largely in conformity to ritual which had for its function the external ordering of the individual life in preparation for 
some higher life in the world to come. No one felt that it was possible to reconstruct society. The superior Christians could only come out from the world and await the coming of the Lord; and under the fixed social conditions that existed in the East, it was but natural that asceticism should become more marked than it was in the disorganized West. The attitude was one of expectancy. This attitude was characteristic of theology as long as the Empire of the West stood, from Paul to Augustine. It was maintained in the East after the fall of Rome.

In the West, however, the development was of a different nature. There the irruptions of the Teutonic peoples destroyed the existing society and imposed upon the Christians the duty of making a new society of the wild tribes which had come into the Empire. Christianity had been unable to reorganize the Græco-Roman Empire. It did not attempt it in theory or practice. But after the fall of the Empire the Church became a civilizing agency, carrying the old civilization over into the newly established barbarian society. The work was not at once recognized as an attempt to reorganize society. Theology continued to occupy the expectant position that has been described. The kingdom of heaven was to be realized only in the next world. Nevertheless, the possibility of reorganization here and there carried the Church over into a new activity. This new activity was possible both because the individual found society falling away from around him, and so was obliged to reconstruct a new society; and because the barbarians who broke into the Empire desired to appropriate the splendid civilization they found there.

\section{THE BEGINNINGS OF THE MIDDLE AGES}

The possibility of this reconstructing activity proceeding from the individual first appears in the writings of Augustine. Augustine was a philosopher before he became a theologian. As a philosopher he would interpret reality from the standpoint of the self; and he emphasized the active will of the individual as the chief force in human affairs. As a theologian he found it necessary to establish the authority of the Church; and so he 
emphasized the freedom of the divine will and changed the doctrine of the individual's freedom almost to determinism. Yet the individual supported by divine grace served practically the same purpose in his social philosophy that a perfectly free individual could have done. He never consciously recognized the possibility of reconstructing society, but the possibility was implied in his individual. Society was going to pieces. When men were saying that the older times when the heathen gods were worshiped were better than theirs, the great bishop of Hippo wrote his Civitas Dei to justify the ways of God to man. Rome had been sacked but a few years before he began the work, and many thoughtful people were beginning to realize that the old social order must soon be dissolved. The inability of man to control the existing social order threw Augustine back on the will of God as the explanation of the development of human affairs. By God's foreordination the elect, since the fall of Adam, had been gathered out of the world; and now while the kingdoms of this world were breaking up, the kingdom of God might go on increasing. This kingdom which had from the first grown up beside the kingdoms of the world would outlast them all.

Immutable and invincible amidst all the instability, agitation, and strife of human things, it is continually drawing into itself its predestined number of inhabitants out of all nations, tribes, and peoples. When the unknown hour arrives which sees their number completed, the last of the elect passed from the city of the world into that of God, then cometh Christ to judge the quick and the dead, and finally to separate the good from the evil; and at his word, above the ruins of those cities of the world that have passed away into the darkness of their eternal doom, there rises in the light of God's love, on a new and purified earth, a new, peaceful, and perfectly happy city which is imperishable, and which contains all the truly good men who have ever lived. ${ }^{x}$

This city of God was not to be established here. In this Augustine agreed with the eastern Christians. He did not consciously look for a reconstruction of society. But the individual whom he had left, while society was falling away from around him, was one from whom might proceed a reconstruction. The

\footnotetext{
I Flint, History of the Philosophy of History, 156, 157.
} 
man who was sustained by divine grace might feel undisturbed by the disorder which existed in society, because the City of God was established on firm foundations and was a commonwealth in which the elect could live harmoniously. Thus, the conception of the Church furnished the ideal of the new city, and the emphasis was thrown on the individual as the only certain element left to enter into this new commonwealth. The importance of institutional life was felt, but only the Christian individuals were left as material of which the new institutions could be constructed. The only sure thing in the world was the inner experience of the individual. ${ }^{x}$ Although Augustine did not himself look for a reconstruction of society, the implication of such a reconstruction was in the individual whom he emphasized. The individual who would live the life of existing society must inevitably go to ruin; yet Augustine saw that the new social organization, wherever it was to be, had to grow out of the individual. The world could no longer be counted on as it stood. The individual was left, and society had fallen away from around him. Therefore any reconstruction had to be from the standpoint of the individual who was left. Augustine would have this new social organization in heaven, and urged the individuals to flee from the existing world in order to attain to righteousness.

Now the people of western Europe were too youthful to flee from the world, even when their religion made them believe that the ideal society could be realized only beyond the grave. So the ideal of the new social order growing out of the individual could be accepted; but instead of fleeing from the world, as Augustine recommended, they attempted to reconstruct the world to meet the needs of the individual and to realize the ideal of Christianity. Along with an acknowledged sense of weakness and humility, these people had a consciousness of strength which they never admitted even to themselves. Men desired nothing in the world, yet set themselves to conquer the world. Western monasticism, which arose from the same conditions that had inspired Augustine, became a civilizing agency, always keeping

$\therefore$ Windelband, $o p$. cit., $270,276$. 
in contact with the social life and invariably coming back to social life, even when its promoters sought to withdraw completely from it. This world was regarded as nothing, yet the Church desired to get possession of as much of it as possible, and to bring its populations into the Christian fold. On the part of the Church, then, representing the ideals which had come down from the past, there was a growing feeling that the existing chaotic society should be reorganized on the basis of those ideals. The ability of the Church to undertake this task was due to the perfection of its administrative machinery; and the perfection of this machinery is accounted for, partly by the survival of some remnant of the old Roman practical genius, partly by the fact that the Church was left to manage its own affairs undisturbed by the civil authorities.

So much for the attitude of the Church toward the social problem of the Middle Ages. Of equal importance for the future was the attitude of the barbarians toward the heritage which had passed into their hands from the three ancient civilizations. These barbarians brought into the civilized world practically nothing except their personal vigor and a certain spirit of independence. It is a mistake to assume that they brought even the principle of individuality. That was the contribution of Israel. The Teutons brought individuals, not individuality. No such conjuncture of affairs had ever occurred before in the world's history; none has occurred since. "The ancient world had developed its own civilization; modern Europe received that civilization and appropriated it."I Each of the preceding societies had been helped by older civilizations, but each had developed to a considerable degree along independent lines, and was simply helped along in the same direction by what it received from others. No elements of civilization which proved to be of peculiar value had been developed by the Teutonic tribes before they came in contact with Rome. At that time, they probably possessed no element of culture which had not been common to the other important Aryan groups when the

Mead, ibid. 
latter were at the same stage. This statement does not detract from their importance in the development of modern civilization; for the other societies had exhausted themselves, and the continuance of social evolution depended more upon vigorous raw materials than upon institutions.

The Teutonic peoples had probably entered the territory north of the great mountain systems and bounded by the Elbe and the Oder about the time the Greeks and Italians had taken possession of their respective peninsulas. ${ }^{x}$ But the character of their country kept them from making any considerable advance. The swamps and forests of Germany prevented the tribes from advancing in civilization, but they were also a protection against the Romans. The Germans described by Cæsar were still largely nomadic, living in village communities which were frequently moved, and, in general, had reached an economic position corresponding to upper barbarism. ${ }^{2}$ The Suevi had not had settled homes for fourteen years. ${ }^{3}$ The political organization was still formed on the basis of kin, the family being of the patriarchal type. The chief of the tribe, the cyning, was chosen from the privileged family that was entitled to that office, and was elected only in the sense that the eldest male in that line could be set aside by the tribesmen on account of feebleness or other disqualification. The tribe was formed by the union of a number of clans or gentes, as in the case of all other peoples amongst whom we are able to find a tribal organization. Since the patriarchal system had done away with exogamy, these gentes had lost their significance as marriage groups. The elders of these smaller units, corresponding to the sachems of the North American Indians, formed the tribal council whose chief function was to maintain the established customs of the tribe. These chiefs had doubtless led in war and governed in peace in the earlier history of the tribes; but as the customs of succession and tenure of office became more settled, it might frequently happen that

Müllenhof, Deutsche Alterthumskunde.

- De bello Gallico, iv, r.

3 Ibid., i, 36, 5 r. 
a wise chief would be a failure as a captain. Under such circumstances, when military operations became of pressing importance, the tribesmen had to select a man of known bravery and skill to serve as war-chief. Finally, the war-leader became a permanent institution as the heretoch. The royal line, although tending to degenerate, was too firmly established to be set aside; but practical necessity led to the development of a special warchief. Tacitus distinguishes between the princeps and the $d u x$, intimating that the latter secured his position by the admiration which he could inspire in his fellow-tribesmen. ${ }^{x}$ This passage in Tacitus is also interesting as showing how little military leadership was required. ${ }^{2}$ Tribal warfare consists in constantly recurring feuds, rather than in systematic military operations. As among the North American Indians any brave who wanted to start an expedition could gather companions by sending out invitations and giving a dance, so any Teutonic warrior of recognized valor might gather a war party; and, as among the former people one of these band-leaders would be chosen by natural selection as the war-chief of the whole tribe, should the war assume tribal significance, so the Teutonic marauding chief became the "host-leader" for his whole tribe, or even a confederation of related tribes, and finally usurped the power of the hereditary chieftain and overthrew the tribal constitution. ${ }^{3}$

The decay of the tribal constitution was hastened by the changes which took place in the economic life of the people. The chief trust of the Germans had been in their flocks and herds, yet a rude system of agriculture was maintained. The natural environment made it impossible to carry their agricultural development very far. ${ }^{4}$ The population was sparse, and when it increased beyond the food supply, the tendency was to wander to new lands rather than to develop a more intensive system of

Germania, vii.

2 "Duces exemplo potius, quam imperio, si prompti, si conspicui, si ante aciem agant, admiratione præsunt."

3 Cf. Morgan, Ancient Society, II7, 118, 146, 147.

4 "Agriculture non student."-Cæsar, op. cit., vi, 2 r. 
agriculture. In so far as such semi-nomadic habits prevailed, common land was much more important than private property; and accordingly we find no evidence of private property in land at the earlier period. Communal ownership of a more or less permanent character doubtless prevailed; for cultivation almost invariably involved clearing of forests, and even when the cleared fields were exhausted by repeated cultivation, they continued to have value as grazing-land, while adjoining stretches of woodland could be cleared for cultivation. Perchance the original fields would again be cultivated, after lying fallow for a while, when the beginnings of a two-field system would appear. In many cases, however, the tendency to migrate counterbalanced the valuation which the community placed on its cultivable lands; in no cases were conditions sufficiently settled to permit private ownership to emerge.

But by the time of Tacitus, a marked change was taking place in Germanic life. Agriculture was becoming much more important, and private ownership had begun in some sections. ${ }^{3}$ This change had been caused by the Roman barriers which for a hundred and fifty years had been crowding the tribes back upon themselves. As the population increased beyond the food supply, it became necessary to resort to more intensive methods of agriculture. And when the nomadic wanderings were checked, the tribes tended to become consolidated and thus to form nations which were finally able to sweep away the barriers. ${ }^{2}$ With the advancing need of land for agriculture, the power of leaders who conquered lands became greater. The congestion on the borders caused intertribal struggles for existence. The heretoch, who had formerly been a temporary functionary, now became a permanent chieftain. The whole social organization took on more of the character of the comitatus, for the tribal lands needed constant defense or new lands had to be conquered. Under the pressure of constant warfare, the old clan system tended to disappear. The war-leader displaced the old chiefs and became

\Germania, xvi, xxvi.

2 Arnold, Deutsche Urzeit, 81-84. 
a king. When the tribes invaded the Empire, these military chieftains became supreme rulers of their people. Neither the tribes that entered the Empire nor those which took their places in the German countries could settle down in peace. Consequently the organization based on relationship had to yield. ${ }^{x}$ The changes in Germanic institutions by the time of the invasions amounted to a transition from communal holding of land to private ownership by leaders at least; and from a clan organization to a militant organization in which the leaders became virtual kings and the owners of most of the land. None of the normal Germanic institutions remained to become the basis of new institutions in the western world. The war-leader became the feudal lord, and could be a vital institution only during the period of frequent wars. The Teutons brought no institutions which were to play an important part in the later social development. They were truly barbarians when they began to work over the civilization found in the conquered provinces; but they were barbarians who had come to admire the civilization which had so long confronted them.

During the four centuries preceding the invasions, the Teutonic peoples were being powerfully influenced by this civilization. They invaded the Empire only after having lived under its influence for a long time. With the extinction of the Roman peasantry, the army had been largely recruited from among the tribes of the border. Commerce was brisk between the Roman merchants and these border tribes at least. Many of the barbarians had been admitted to rank and office in the Empire. Alaric had been in the service of Theodosius. Theodoric had passed many of his earlier years in Byzantium; and while his kingdom passed away too soon to have a direct part in the development of European civilization, the aims of his administration must have served to stimulate other barbarian leaders. Above all, the Christian missionaries had early begun to carry their religion to all accessible tribes; and the influence of the religion of civilization was marked even among those who did not accept the orthodox

× Wietersheim, Geschichte der Völkerwanderung (Dahn ed.), I, 35-73. 
Roman faith. The West Goths had been converted about 375, the East Goths and Vandals a little later, the Burgundians early in the fifth century, the Franks, Lombards, and Anglo-Saxons not until somewhat later, but even these peoples came under the influence of Christianity soon after their migrations. But whether Christian or not, nearly all had come to know and appreciate the greatness of Roman civilization. The tendency toward monarchical institutions which we have already noted strengthened their regard for Roman political organization, for the barbarian leaders found the latter well suited to increase their power.

Thus when the final movement came and the Teutonic tribes slowly established themselves through the provinces, they entered not as savage strangers, but as colonists knowing something of the system into which they came, and not unwilling to be considered its members; despising the degenerate provincials who struck no blow in their own defense, but full of respect for the majestic power which had for so many centuries confronted and instructed them. ${ }^{x}$

The elaborate philosophical system, the statuary and painting, the cultivated language and literature, the luxuries of the wealthy Romans, probably impressed the barbarians but slightly, for the appreciation of these things depended upon intellectual and æsthetic training such as few of them had enjoyed; but the admirable machinery of government, the massive buildings, the stately religious ceremonial, the well-tilled fields, the busy workshops, deeply impressed the invaders. They entered the provinces not for plunder but for settlement; and the existing social organization supplied-

what they most needed and could least construct for themselves; and hence it was that the greatest among them were the most desirous to preserve it. The Mongol Attila excepted, there is among these terrible hosts no destroyer; the wish of each leader is to maintain the existing order, to spare life, to respect every work of skill and labor, above all to perpetuate the methods of Roman administration and rule the people as the deputy or successor of their emperor. $^{2}$

Had the Teutons been mere destroyers, the outcome of the

x Bryce, The Holy Roman Empire, I6.

Ibid., I7. 
movement we are tracing would have been vastly different. They would then have settled in a favorable country for the development of a civilization; but having destroyed what they found there, their progress would have been very slow, and probably they would never have been able to attain to any such highly developed social life as we find in the world today. There is no reason for believing that these barbarians who for centuries had scarcely changed their social habits in the slightest degree would have been able to work out a highly developed civilization without the assistance of antiquity. The migration to a more favorable habitat and the modification of their social habits consequent on such a change might have set them on the way to a high civilization, but it is improbable that they could have been more successful than any one of the great societies which we have already considered. No such complex, mobile, and progressive society could have been produced had not the results of the previous development been appropriated by the Teutons. The latter were not mere destroyers. They disarranged everything then in existence; they marred and ruined many things of inestimable value; violence and barbarity ruled for ten centuries; but they nevertheless set themselves to appropriate the essential elements of the civilization they had overthrown and were ready to receive the ideals held by the one institution which had survived the fall of the Empire.

Thus we find that, on the one hand, the Church had come to undertake the reconstruction of society, and, on the other, the barbarians were ready to receive the ideals which would enable them to constitute the reconstructed society. Before tracing farther the effects of this attitude of the barbarians, the relation of their migration to the increased power of the Church must be noted. This has been partially explained above, but there are other reasons to be given for the tremendous power of the Church over the barbarian mind. The Church had this power both because it was the representative of the old civilization for which the new peoples had so much respect, and because conditions were favorable for the development by the Church of certain 
magical powers which would enable it to exercise almost absolute authority in directing the ethical life of Europe.

The disorganization of social institutions and the loss of control of the natural environment created a demand for magic. ${ }^{x}$ The Teutons comprehended little of natural laws. Like all primitive peoples, they attributed all natural phenomena which they could not control to supernatural power. In this respect they did not change their views when they entered the Empire. Indeed, their beliefs were intensified by the change of environment that brought to their attention new phenomena of nature. Even the ancients had not quite reached the scientific point of view. Supernatural power was still called in to explain many of the phenomena that confronted them. But many of the forces of nature had been reduced to order. When they could be controlled, they were no longer supernatural. The decadent society of the fifth and sixth centuries had lost much of its scientific knowledge, and was coming to have more fear of the supernatural. When, therefore, the barbarians came in with all the new superstitions which contact with a new environment aroused, society was well prepared to resort to magical means to control the divine powers that seemed to bring more evil than good to man.

Further, the entire change in social life on the part of the Teutons and the breakdown of the social organization of the Romans were a still stronger reason for resort to magic. Social dislocations have always tended to make men resort to magical methods to bridge the gap between the old social habits and the new situation. At this time both Romans and Teutons had suffered a severe social dislocation. The established social habits could no longer function. The Roman saw the Empire which had seemed eternal losing its power. The German had before him an ideal of social life which his old methods could not enable him to realize. The invasion of North America naturally led to the rise of the medicine-man among the natives; in Europe both conquered and conquerors were confronted by

I I use this term for want of a better one. It is not intended to imply wilful deception on the part of the Church. 
a social situation for which past experience had not prepared them, and both demanded some supernatural assistance in the transition from the old order of things to the new.

Now, the same social disorders which drove away from the world those men whose temperament enabled them to realize in emotional terms the new social order, gave them power to become mediators in the world. Since the barbarians had largely come under the influence of Christianity, the priests naturally became the mediators between man and the supernatural powers which alone seemed able to control the social order. With this belief once established it would naturally grow in intensity. The recognition of the powers of the saint led many of the most ambitious spirits of the age to enter holy orders. Under the Empire the clergy had been subordinate to the government, and the Theodosian code still shows the supremacy of the civil authority; but by the middle of the fifth century the priesthood had come to have a power over the popular mind that was almost autocratic. Again, during the period of order under Charlemagne, the supremacy of the civil power was marked; but during the period of anarchy following, the Church became even more powerful because more strongly established by the protection it had received. The culmination of the disorders consequent on the fall of Rome was the founding of Monte Casino (529), though it was not until somewhat later that the Benedictine order arose to great power. The culmination of the disorders of the Carolingian period was the founding of Cluny (910), though it was not until ro73 that the representative of this monastery, Hildebrand, gained complete control of the Church. ${ }^{x}$ Attention will be directed later to the importance of magical powers in the eleventh century, when they received their greatest expansion. The same causes, however, led to the supremacy of the Church at the very beginning of the invasions. The demand for a miraculous bridge between the chaos of existing society and the ideal society before both Roman and Teuton led to a supply of magic by the Church.

I Hildebrand may be considered the supreme power from I049, when he became the minister of Leo. 
The civil power had become practically extinct, and the imagination of the world was enslaved by superstition; therefore the Church in serving as a mediator secured also a power over men that enabled it to mold them largely to its liking. The fear of miracles exempted one class from violence in the midst of universal lawlessness; and more than once whole communities were protected from ruin by the spiritual power. Even Attila the Hun turned back in terror from Aquileia when confronted by the stately presence of Leo, although the Roman soldiers had been driven from Ravenna. ${ }^{x}$ This supernatural power of the Church made it more efficient than it would otherwise have been in carrying over the ancient civilization to the newly forming society.

\section{THE ETHICAL PROBLEM OF THE MIDDLE AGES}

As we have seen, the barbarians were prepared by long contact with the Empire to accept the essential elements of the old civilization of which the Church was the best representative. This presentation of ideals of social order, on the one side, and this acceptance of the ideals, on the other, constituted the peculiar problem of the Middle Ages. Europe started off with a statement of the problem of social life and had to work up to it. The ancient world had developed its own civilization. The Teutonic peoples started off with the results of previous social development as ideals to be realized. ${ }^{2}$ For the first time in the development of human society the ideas which underlay the social structure were abstracted. So long as the ancient societies had lived according to these principles, they had been unconscious of them. When their social life was decaying, when history was behind them, the ancients began to reflect instead of continuing to act. The conception of free intelligence could come to expression only after Athens had lost her power; that of the ordered state only after Rome had lost her vitality; and that of the identity of human interests within the society could culminate in the teaching of Jesus

I Cf. Hodgkin, Italy and Her Invaders, II, 122, 161, 514 .

2 On this point I am especially indebted to Professor Mead for many fruitful suggestions. 
only when the Jewish community was passing away. When abstracted, these ideas became ideals, and were carried over to the Teutons chiefly in the religion which survived the fall of the Empire. A part of the intellectual content of ancient civilization was carried over in the doctrine of the Church, something of the administrative framework in the Christian hierarchy, and the general ethical conceptions of Jesus became the essential life of Christianity. All these were blended in a general ideal to which may be applied the somewhat elastic term "Holy Roman Empire." Europe received this ideal-the conception of a state in which the individual and the community were to be brought into harmony-chiefly through the agency of the Church, and set before itself the problem of realizing it. In the East this ideal was to be realized only in the future life; but in the West the new element that had come into society undertook at once the solution of the problem. This quest was only to a slight degree conscious, for theology did not recognize the possibility of social reconstruction in this life, but it was none the less real. Europe did not face the necessity of attaining new ideas. The ideas were already given. The attempt was being made to apply them. A statement of civilization was given, and Europe had to catch up with it. Antiquity had achieved civilization; modern society had civilization forced upon it.

The problem was to bring the various particular objects and activities into the scheme of universals that had come down from the past-to apply the universal, "Christendom," to the various discordant tribes and nations, or rather the infinite number of local groups, whose economic and institutional life kept them from uniting in a society which would realize the ideal. All thought and action was to be tested by these ideals which had come down from the past. Therefore, the conception of authority, which was altogether absent in Greek thought, became of very great importance. Since it was not a matter of attaining new ideas, but of catching up with ideas already given, the important thing was to hold Europe to the line of thought which was given. The unity of European society was found in these common ideals. 
Wars were constant, but they were never a unifying force, as they had been when Rome gathered together a world-state. Economic activities were quite similar in all parts of Europe, but in the absence of exchange there could be no unified economic life. It was only in these ideals that a foundation existed for the development of an organic society.

The Church naturally became the teacher and authority, for the Church was the only institution which was identified with the past, and these ruling ideals were characterized by certain important religious aspects. Until the general scheme of social life had been filled in, advance was impossible. Until the given line of thought had been realized in life, this authority could not be overthrown. When advance no longer consisted in realizing ideals which had been furnished by a society that had passed away, a reaction against authority was natural and necessary. Further progress did not depend upon obedience to it. Not simply because of the magical powers ascribed to the Church, but because the barbarians accepted the old system as an ideal to be realized before any further progress could be hoped for, did Europe bow before a power not of its own creation.

The ethical development of Europe, therefore, consisted in attempting to realize the ideals for which the Church stood-in general, a unified Christendom in which the individual would function, not for a small community, but for the whole organism, and in which the values of the whole would be poured into every individual. It can not be said that this ideal has yet been realized. There is still too much friction in society for us to believe so. And yet, much of this friction, serious though it may be, is of a surface sort, and is not inconsistent with a general identity of interests within a world-embracing society. The welfare of each is now actually dependent upon the proper functioning of the whole. The universals which came down from the past are now largely exhausted, and further social evolution must consist in developing ideals in the very social process which is in turn to realize them and necessitate still other ideals. This is the capital difference between modern society and society from Augustine to Descartes and Hobbes. 
The peculiarity of the ethical ends of Europe necessarily made the ethical problem peculiar. This peculiarity consisted in the manner in which the means for the realization of the ends had to be worked out. The ends were given. So far the ethical problem was simple. But these ends had to be used to direct the means of their own realization. All that the Church could do as a teaching institution was to present the ideals. Beyond this it was as powerless as the old Empire which then had no significance save as a bare ideal. But the Church was a living institution, and was therefore a part of the society that was attempting to realize the ideals which the same Church, as an external power, was holding before that society. It therefore not only presented the ends of social action, but attempted to apply these ends in the organization of means. The most important means of reaching the ideal was magic. But the Church played a most important part in organizing real means, that is, in directing the economic development. The traditions of the Church and the natural selection made possible by its purely democratic character enabled it to furnish such administrative assistance as served to prevent total social dissolution, and, especially in the Frankish kingdom, to bring about the blending of the barbarian and provincial elements of the population. And the same democratic features brought to the front the enlightened intelligence which could make the domains of the monasteries and cathedrals the highest examples of economic development in mediæval Europe.

The ends being given, the problem was to organize the means by which they were to be realized. Our previous investigation has had to do with the development of the ends which were to be set before Europe. After this chapter the investigation will have to do with the development of the means by which Europe was to realize the ends. The ethical side of the problem is found in the reaction of the given ideals upon the means which were being organized. The economic side is found in the development of the means themselves-usually economic in the narrower sense of the term. The political side of the problem is found in the gov- 
ernmental arrangements as they existed at various periods. Unquestionably the political framework has reacted powerfully upon the other factors at various times; but on the whole it has usually been merely a partial expression of the social life as determined by the ethical and economic development. This was undoubtedly true during the greater part of the Middle Ages, when the political organization was almost nil. This aspect of the social life will therefore require but incidental attention, either as the political power reacts on the general social life, or as the political structure represents the attainment up to a given date, and so both a help and a hindrance to further advance.

Since the main problem of Europe was the organization of means, it may be asked: Did the social ideals as held by the Church actually have anything to do with the social evolution? Would not the outcome have been the same without them? This question has been discussed in our consideration of the possibilities of the Teutons left to themselves. The ideals from the past were inextricably bound up with the whole social development. The struggles of popes and emperors for supremacy meant more than mere efforts to gratify selfish ambition; they were an expression of the dominance of the ideal of a unified Christendom. Had not Europe been pursuing this ideal, neither popes nor emperors could have gained the following they had. Even although the immediate efforts to organize Christendom were inevitably doomed to failure, and although when the organization came it was vastly different from anything popes and emperors had dreamed, yet the efforts which kept Europe alive to its purpose had much to do with the final outcome.

An eminent historian has contrasted the reigns of Charlemagne and Otho, very much to the discredit of the former. He has correctly shown that Charlemagne's efforts to establish a universal empire were futile, and, indeed, were directly in opposition to the necessary course of events. The strong arm of the great emperor alone could hold the diverse interests together, and the welfare of all sections demanded that each should be permitted to work out its special problems undisturbed. Charlemagne at- 
tempted to join together what the nature of things was disintegrating $;^{\mathrm{r}}$ and can not be regarded, from this point of view, as so truly advancing the real interests of society as Otho did when he organized the Empire upon a feudal basis. Under the latter régime each local community was allowed to pursue the course which its situation seemed to demand. Europe was not yet ready for unification, and attempts to realize that dream seemed to hinder rather than help true progress. ${ }^{2}$ And yet the success of Charlemagne in welding the nations together in one whole, artificial and temporary though it was, made it impossible for Europe ever again to forget its destiny. Charles was as truly an expression of the spirit of Europe as Otho was. By a fortunate conjuncture of affairs he was enabled to use his great genius in setting the standard for six centuries. The ideal was not realized as Charles thought, but the more definite statement of the problem assisted men in its solution, and even made possible the Ottonian empire. The neighboring Teutonic tribes were brought within Christendom because it was felt that they were less heathen than the Huns and Saracens who were threatening the whole society. The attacks of these latter peoples brought Europe to a more conscious recognition of the true ends of Christian society. Charlemagne's empire was an expression of this consciousness of a controlling ideal-the Holy Roman Empire, the unified Christendom.

The Holy Roman Empire existed as a reality only during the lifetime of its great founder. "That passionate longing of the better minds for a formal unity of government, which had its historical basis in the memories of the old Roman Empire, and its

× Sismondi, Histoire des républiques italiennes du moyen age, I, 34-37.

2 "Othon ne fut pas moins grand que Charlemagne; et son règne eut une influence plus salutaire sur le sort des peuples qui lui étaient soumis. Charles eut l'ambition des conquérants; et, pour élever son empire, il détruisit l'esprit national, et avec lui la vigueur des peuples qu'il avait vaincus: Othon ne remporta pas de moindres victoires que lui; mais ce fut sur les enemis de la civilisation, sur des agresseurs qui dévastaient l'empire par leur irruptions. Othon ne chercha pas à étendre les limites de cet empire; il n'ambitionna pas d'autres pouvoirs que ceux qui lui étaient nécessaires pour protéger ses sujets, et, après avoir rendu la paix à ses provinces, il mit les peuples sur la voie de se passer un jour d'une autorité semblable à la sienne."-Sismondi, op. cit., I, 82. 
most constant expression in the devotion to a visible and catholic Church," was still not strong enough to overcome the tendency toward separation caused by the ungoverned impulses and barbarous ignorance of the masses of men-men who were feeling after a better way, yet had neither the resolution nor the control of their natural environment that were necessary for the perpetuity of the empire. Charles failed in his attempt to run Teutonic life into Roman forms. The Church itself was not disposed to surrender its powers, but the Church could maintain its position because of the discordance of the component part of society.

The nations were not ripe for settled life or extensive schemes of polity; the differences of race, language, manners, over vast and thinly peopled lands baffled every attempt to maintain their connection: and when once the spell of the great mind was withdrawn, the mutually repellent forces began to work, and the mass dissolved into that chaos out of which it had been formed. Nevetheless, the parts separated not as they met, but having all of them undergone influences which continued to act when political connection had ceased. For the work of Charles-a genius pre-eminently creative-was not lost in the anarchy that followed: rather are we to regard his reign as the beginning of a new era, or as laying the foundations whereon men continued for many generations to build. ${ }^{2}$

The real work of construction, however, had to do with the unifying of the activities of men in this broken society. The life of society was particular, not general; and therefore the universal statement, however exalted, could never realize itself. To men living at the time, the universals which had been transmitted by antiquity seemed to be the important things. In a certain sense they were. But the work of men had to do with the particular facts of life until the latter could be brought into harmony with the universals. Yet in thought the universals that had been received from the past were separated from the particulars of life, just as there was a separation between the ideal social order and the individual.

In Greek thought the generalization had been reached by the examination of the particular. The particular might then be

Bryce, op. cit., 50, 5 r.

Ibid., 7 I. 
neglected as interfering with the consideration of the universal; but the universal was never reached in any other way. In medixval thought the generalization was received from the past and held irrespective of the particular. It had not been derived from a study of the particular. It could not be derived from the examination of particular facts then existing. Mediæval ideas were given, whereas Greek thought had achieved ideas. Men could not wholly neglect the actual facts of experience, except in the case of a few ascetics; but the ideals which had been received as a heritage were so unmistakably important that in some way or other the particular facts of life had to be controlled with reference to them. There was thus a tension between the ideal and society such as was not found in ancient times. The problem was not, as in Greek thought, to develop a system of generalizations from a study of the environment natural and social, but to bring various particulars into a hierarchical scheme of universals. The Aristotelian logic was reached by a study of particulars. The mediæval logic was the systematization of Aristotle's logic; and into the hierarchical system, at the head of which stood absolute being, all particulars were to be brought. The stimulus to activity was not found in the particular circumstances, but in the whole system that was given. This attitude was never changed until Europe had finally exhausted the system of universals and was obliged to frame new ideals to guide social action.

So it came to pass that men regarded the universal as the reality existing apart from the particular. The Church was a true universal and had an existence apart from the individuals who composed it. Under the influence of Gregory, the Church became the expression of the Deity and stood between man and God. The long, uninteresting controversy about realism was not a mere abstract speculation. It was the reflection of important social facts. Prolix and artificial though the investigations were, they are not to be dismissed as meaningless. Ideas were the most real things in the world. The universal Church and the universal Empire were essential to the development of society. To take 
away these universals would be to take away the only bonds which held Christendom together. The universal could not be seen in the particular and the particular neglected, as with Plato; the known objects were wholly opposed to the universal, and the reconciliation had to be brought about by bringing the particular into harmony with the universal.

The reconciliation of the particular with the universal was the peculiar task of the Middle Ages. In some respects, as already explained, the attempt was made to bring this about by magic; in other and more important respects, the discordant particulars were actually grappled with and worked over. The philosophical statement which corresponds to this attitude of Europe was most definitely made by Anselm. With him the reality was always the good, the ordered, in the midst of the disorder of the world which was to pass away. The more absolute God could be made, the more real he would be. The doctrine of the atonement, which was stated by Anselm, is a purely universal statement wholly abstracted from the realities of life. The holy life could be attained only by penance; and this penance was different from that of the eastern ascetic who sought to get rid of the particular in contemplation of the universal: it was a positive subjection of the individual to suffering for his $\sin$, in order to make him correspond with the ideal. Magic was but an effort to realize universals that were vaguely understood and which the means at hand seemed incapable of realizing. The sacrificial death of Jesus was the most efficacious of these magical means for bridging the chasm between sinful, helpless man and the absolute God; and therefore, the repetition of the sacrifice in the daily mass was the most important of all religious acts. Atonement became the central feature of reality. There was no desire for a holy life on the part of the individual; he desired only the forgiveness of sins. Thus, in the religious life the particular could be brought into harmony with the absolute, not by actual modification of the particular, but by this magical means.

This philosophical statement of the broken social relations was made by Anselm (died Irog) at the very culmination of the 
Dark Ages when the reconstruction of society was actually beginning. It was then that the movement would naturally come to consciousness; for when the universals were being applied at different points in the civilization of Europe their importance would be appreciated even more than during the darkest period. It was also at this time that Hildebrand was bringing the Church to its highest position.

Naturally also, at this period, when the reconstruction had already begun, when the universals were being realized at particular points in detail, some men would begin to see the importance of the particular facts of life, not because the universal was realized, but because the particular was being used. The particular was there, and to some it seemed that the universal was not present. This growing recognition of the particular was represented by nominalism. This was not a mere common-sense reaction against realism, but was the statement of another aspect of the very condition which led to the opposing conception. Like realism, nominalism accepted the given ideals. No attempt was made to draw generalizations from the actual facts of life. The particular was recognized as important simply because it was being used in realizing the universal. The particular was being taken into account in the reconstruction of society, yet no universal could be given for these known particulars. So the universal became, first, a name, later, a state of consciousness of the individual. As Anselm had laid the emphasis on the universal which was to be applied, so Roscellinus recognized the importance of the particulars which were to be worked over. As Anselm was the Charlemagne of theology and philosophy, so Roscellinus was the Otho.

Since this nominalistic movement in thought was likely to draw attention away from the ideals of Christendom and cause disintegration by fixing the interest on details which were so faulty, Roscellinus was convicted of heresy (I092) and nominalism was suppressed until toward the close of the Middle Ages. The realistic movement culminated in Thomas Aquinas (1225-74), when the actual reconstruction had proceeded so far that those 
who stood for the established order of things in the Church sought to check it by giving the old ruling theory a new statement. The nominalistic movement again became prominent, after the problems had been practically solved, as a recognition of the universal as a psychical state. This movement culminated in William of Occam (died I374). Of the other philosophical statement, conceptualism, nothing need be said here. It was chiefly a mediating movement, seeking to recognize both the universal and the particular, but laying the emphasis on the subjective rather than the objective side. This movement was likewise condemned when Abelard was convicted of heresy (II22). It is important to note that in all these controversies the essential importance of the ideals held by the Church was not questioned. Some men simply tended to lay the emphasis on the materials which were to be molded in these forms. The main emphasis naturally remained on the universals which were to control all particular activities; and, on the whole, we must admit that the Church was justified in resolutely stamping out any movement which would tend to cause disintegration by turning attention from the only things that could really be counted on. In some important respects the universals were the most real things in the world. Only by emphasizing them could the ethical development be carried forward.

In so far as insistence upon the line of social activity was concerned, the Church was evidently right. In attempting to solve the problem of the conflict between the particular facts of the broken social life and the ideal social order by magical rites, the Church was manifestly engaged in a fruitless endeavor. And yet this (to us) foolish attitude may have been necessary in order to hold the barbarian world to its mission; for the control of the imagination thus secured certainly had much to do with the direction of the social activities. However, there was one sphere within which no magic could avail. With reference to general theories and religious satisfactions, the chasm between the particular and the universal could be bridged by the agency of the Church; but with reference to the actual social life itself, it could 
be bridged only by the particular activities of the social life as guided by the accepted ideals. No magic could span the gulf between the actual poverty and disintegration and the ideal of a united Christendom. And yet the realization of the ideal depended upon the development of an economic community which would embrace all Christendom, in which through the division of labor and the free exchange of products each individual would function for the whole and be benefited by the activities of the whole. It was this hard fact which prevented the formation of a pure theocracy. The Church might try to get men to live for the better social order of the New Jerusalem, but since the western peoples were too vigorous to be willing to flee from this world and find their satisfaction in the contemplation of the ideal future world, they attempted, and the Church unconsciously assisted, the reconstruction of the existing social order. So long as men aimed at this economic development, no manipulation of the imagination could completely control them. Therefore a pure theocracy could not be established, and the miraculous work of the Church could only partially satisfy the needs of the age. But it was only as the wider economic community developed, so that there was a real division of function along with the working for a common result, that the magical and emotional mediation between the individual and the ideal community could be done away and the identity of interests of the individual and of the community be made one of fact. The ethical realization depended on the industrial. The ends could be stated only in emotional terms until the means had been organized. The ethical evolution was completely bound up in the economic.

As with the larger social ideals, so with the minor ends of activity in the smaller political divisions, on the manor, in the atelier. They were given; and the individual in his activity sought to realize them. In organizing the administrative machinery of their new countries the barbarians had no higher ideal than the system which had been in operation. Not only did they seek to perpetuate the Empire; in the immediate matters of administration they sought the advice and help of the Christian bishops and 
Roman officials, desiring to retain in their own hands only the military power and the general control of the whole system. So also the ordinary comforts which were the product of industrial activity were desired by the conquerors, but they could secure them only as the old laborers could be induced to carry on production somewhat after old Roman methods. The development of agriculture and manufactures had to follow the lines laid down by the Romans, modified by the limitations of cruder workmanship. The economic patterns, like the ethical, were received from the past.

There was no province from which the barbarians effaced all traces of Roman occupation. Even in Britain, the cherry trees and quickset hedges, the wheat and the cattle, suggest the tradition of Roman agriculture; while the roads, canals, and buildings afforded models that were followed in subsequent times.... The physical relics of Roman civilization remained throughout the greater part of the West; and in some cities vestiges of Roman civilization were maintained. There was a great heritage of manual skill and mechanical arts which had been slowly built up in Egypt, Phonicia, Greece, and Carthage, and which was incorporated in the culture which the Romans diffused; and it may be doubted if any of the industrial arts as known and practiced by the Romans was wholly lost in the West. There were, besides, forms of economic life which reappeared when circumstances admitted of the revival; there was no need to invent them anew. The organization of the mediæval estate has its analogue in the Roman villa; the mediæval city, with its gilds, is the reproduction of the Roman town and its collegra. $\mathrm{x}^{2}$

Much was lost beyond recovery in the first confusion; but many of the methods were carried over by the industrial classes, and upon them the new lords had to depend for what they could not themselves produce. "Civilization" in all of its known aspects was an ideal. It could not at once be realized, but there was an unconscious movement toward its realization at particular points. On all sides of life the most real things in the world were the ideals which had been inherited from antiquity. All of the particular things of life were mere stuff to be worked over according to the

Cunningham, Western Civilization in Its Economic Aspects: Medicval and Modern Times, 5, 6. Continuity can be proved only in a few Italian cities, but the influence of these cities on the newly developing towns is undoubted. 
pattern set. But on the economic side no legerdemain and no emotional contemplation could harmonize the particulars and the universals. To secure the results the industrial life had to be carried forward; and in carrying it forward a result was secured that had not been anticipated, namely, the realization of a social order which men had thought possible only in the future world.

Regarding the industrial classes, an important consequence flowed from the nature of the industrial life. This will appear in the following chapters, but its general character should be noted in connection with what has gone before. The barbarians who were the political masters wanted a civilization whose general characteristics they had learned from the ancient world, but which they did not know how to produce. The demand for this civilization was made on those whose lives were under the control of these masters. But in meeting this demand the laborers had to be left free to adopt methods which had been carried over from the past, or which they might work out for themselves. Only the result could be demanded by the masters. The technique had to be left in control of the laborers. The barbarian lord knew nothing of the processes involved in the production of what he wanted, and the society which he represented had no agents who could control the processes. Barbarian society could not direct the laborers and artisans as ancient society had done. It had no social organs, no entrepreneurs, to perform that function. This was a great advantage to the laborer in many ways. His technique was set free, though his person might not be legally freed. This technique was carried over, to a certain extent, from the Empire; to some extent it was the gradual development of the laborers themselves as they worked under the guidance of the general ideals that were given. The results, at first, were necessarily crude; for the barbarians were easily satisfied, and there was no stimulus to high productivity either in quantity or in quality. In any event, the technique remained outside of the political organization of society. In ancient times, as has been shown in our consideration of the Egyptian and the Greek indus- 
trial development, ${ }^{\mathbf{x}}$ society controlled both the laborer and his labor. Society was able to determine where the product was to go and how it was to be produced, because the social organs for such control had been developed. Hence the distinction between the slave and the free artisan had tended to disappear. The Roman college was little more than an organization for police purposes. Its members had a task to perform which was imposed upon them by society. But society was unable to control the technique of the mediæval laborer. If the given results were obtained, society would not interfere with his methods. And the results demanded were such that the laborer was able to participate in the consumption of nearly all classes of commodities produced. The gild, when one was formed, determined for itself how the work was to be done. Hence the laboring class continually demanded and received greater freedom. The technical freedom ultimately involved political freedom. There was a constant advance in the expression of the individuality of the laborer.

It should be noted, however, that this expression of the individuality of the laborer was for a long time within his calling. The industrial institution-first the manor, later the gild-controlled the end which he was attempting to realize. He enjoyed a growing freedom, but it could be exercised only within the institution to which he belonged. The institution had the place of mediator between the laborer and his economic ideals, as the Church had on the ethical side. The individual's activity had to be within the institution. But the gap here could never be spanned by supernatural means. It depended upon the technique of the laborer to accomplish this result; and, therefore, he was left free within the institution. Hence, personal slavery had to cease, except in the case of a few domestic servants, while serfdom could continue so long as the manorial organization lasted, that is, so long as the baronial master gave orders for his own purposes. When the demand for the products of industry came from a larger community, when the demand was truly economic and no longer that of a political master, even that serfdom had

I Supra, 28-33, 40-42. 
to pass away. The institution of the manor was then no longer needed to mediate the individual's activities. He began to function in and for a larger society.

In conclusion, the actual reconstruction of society meant a change from the emotional recognition of social relations to an intellectual recognition. So long as the ideal was one which went beyond the possibility of actual social relations, it could be held only in emotional terms; it could not be defined. Recognition of sonship of God made possible the recognition in emotional terms of the brotherhood of man; or, in larger dimensions, of a social order in which the individual could normally function as an organ of the whole social organism. This emotional recognition of the ideal social order did not make possible a definition of the individual's rights, powers, and duties, because the latter could only be defined in terms of the social order which at that time did not exist in fact. The intellectual definition of the individual could be made only in terms of the society of which he was the expression. But that actual society was regarded as temporary and bound to give place to an ideal society in which a community of interests would be possible. Only in the immediate exercise of social functions in the new social order could the values of the individual be found and stated in intellectual terms. The bringing of all Europe into the Church had given an emotional value to the individual. Now, when the movement which meant the reconstruction of society in particular respects began, the intellectual definition of the individual began. One after another of the barbarous practices of society was brought into harmony with the social ideals held by the Church. Gradually the social values of the essential activities of life came to be recognized. In detail the ideal social order was becoming one of fact. When the principal functions of life had passed over from the worldly side of the individual to the side which the Church represented, the mediæval period was over and the values of the individual were recognized. The modern individual is as much more complete than the ancient as his consciousness of the social values of his actions is more complete than such consciousness was in any 
individual of the past. Plato's individual was incapable of conscious social activity, but pursued particular ends which an outside authority set for him. The development of the individual which went on during the Middle Ages consisted in the development in him of the consciousness of the social value of his acts; and in proportion as that consciousness became clear his individuality became more marked, until it blossomed in democracy. This intellectual statement of the individual was impossible except as a statement of the whole society became possible, and the statement of the whole society was not possible until the movement begun at the time of the fall of Rome was consummated in the development of a truly organic society which took in the whole civilized world. With the gradual application of the universal to the particular, the gradual realization of the ideal in the particular acts of life, the conception of the simple relationship of the individual to God as involving undefined relationships to men passed over to a conception of the immediate and organic relationships of men to each other. The whole social organism came to act through the particular organ, and when this functional relationship was recognized, the individual was given an intellectual valuation corresponding to the emotional valuation which had been placed upon him by the earliest Christians. The Reformation took place when the intellectual recognition of the essential social activities had developed, and the ecclesiastical mediation between the individual and society was no longer needed and the exercise of ecclesiastical authority in the guidance of life no longer to be tolerated. 


\section{CHAPTER III}

\section{THE ORGANIZATION OF AGRICULTURE}

The statement made at the close of the last chapter indicates the social-psychical development which was correlative with the external social development that has been described as the organization of the means of attaining the ideal social order. The period of disintegration bordering on anarchy which followed the irruptions of the barbarians into the Empire was really a period in which the vigorous but unorganized peoples were feeling after the means for the realization of a unified Christendom, their own dream and the ideal of the Church. Obviously, the first step toward the integration of society had to be the development of a settled food supply. Until a surplus of the bare necessaries of life could be secured, neither the production of comforts and luxuries nor the organization of a considerable political power could take place. The first problem, therefore, was the organization of agriculture. The organization of the agricultural processes was the underlying cause of the development of the feudat system, while the development of an agricultural surplus and the re-establishment of commerce caused the decay of that system.

The problem was a serious one for both the invaders and the surviving Roman populations. To the former the food question had always been a pressing one. In the earlier days, before the Roman barriers were erected, the tribes had moved to new lands whenever the population pressed upon the food supply. After the Roman expansion, it became necessary for them to adopt more intensive methods of agriculture, partly copied from the Romans, partly invented by themselves. But their supply of food was always irregular. Sometimes the larder was bare, sometimes filled to excess. The attempt to settle down in the conquered Roman territory necessitated a more regular food basis. If the Teutonic peoples were to become civilized nations, it would be 
necessary for them to secure a more regular supply of the necessaries of life. This they attempted when they tried to take advantage of the Roman methods of agriculture.

The invasion likewise made the food question one of pressing importance to the old inhabitants of the conquered countries. These lands were, as a rule, very productive, but they had ceased to be self-sufficing. The Romans had developed extensive commercial interdependence. In the most fertile provinces many food importations were necessary. Italy had raised no grain for centuries, and hardly any section was entirely self-supporting. By the beginning of the fifth century, commercial intercourse became increasingly more difficult. The Romans had been on the defensive since the crushing defeat by Hermann in the Teutoberg Forest (9 A. D.). The advance guard of the barbarians crossed the Rhine at the end of the year 406. It was composed of Suevi, Vandals, Alans, and Burgundians. Mayence, Worms, Spiers, Strassburg, Rheims, Tournay, and Amiens were sacked by them. Later, the central portion of Gaul was invaded by the Visigoths, the northern by the Franks, Italy by the Vandals and Ostrogoths. Then came Attila and his Huns, destroying the few remaining cities of eastern Gaul and ravaging the country until they were defeated by the united Romans and barbarians at Chalons in $45 \mathrm{I}$. Society was everywhere disintegrating. Commerce could not exist. Europe, whether Roman or Teutonic, had to develop her own agricultural basis, or perish. Not only so, but each locality had to develop its own food basis, or perish. No considerable interchange of food supplies was any longer possible; and, a little later, almost no other kind of commerce was possible. This condition of affairs rendered it necessary to organize the agricultural processes in such a way as to secure an adequate supply and to render each local community independent of every other community. Only a strong political organization could have kept up commercial intercourse, and no such organization could exist without such intercourse. Further, such an organization was impossible among rough barbarians, for even those who appreciated its desirability did not have the political genius to maintain it. 


\section{ROMAN METHODS AT THE TIME OF THE INVASIONS}

The agricultural system that was organized was modeled chiefly after that which had existed among the Romans. Before tracing the mediæval development, it will be well to have before us a brief description of the Roman system. After a long process of experimentation, the Roman domains had come to be divided into two parts: that cultivated by the familia, the produce of which accrued entirely to the benefit of the master; and that cultivated by small farmers, the produce of which was divided between the farmer and the landowner. Where the slave was permitted to cultivate a separate lot, he was doubtless a tenant on certain days and returned to the familia and worked in the gang on the reserved lands on other days. ${ }^{x}$ This system of working on the reserved lands on certain days was found in the serfdom of the Middle Ages, but not in the old Germanic serfdom. The rural domain was a very complex organization, containing lands of all kinds-fields, vineyards, forests, etc.-and men of all conditions-slaves without tenure, slaves holding allotments, freedmen, colons, freemen. The proprietor received the products of the reserved portions and the rentals of those under tenure. ${ }^{2}$ The same superintendent administered and oversaw the two parts alike.

As to the men on the domains, we find that they were of various conditions. The slaves who were engaged in the personal service of the master, valets, secretaries, couriers, and domestic servants, constituted the familia urbana. The rural slaves, those occupied with the cultivation of the soil and those who constructed and repaired buildings and implements, constituted the familia rustica. The free village did not exist, but all of the elements of the village were found on the domain. The agricultural slave usually cultivated about six acres of vineyard or eight acres of field. The slaves were called servi, but this term, which was retained by the Germans to designate the serfs of the Middle Ages, never meant anything other than slave among the Romans. The true

I Varrus, De re rustica, i, I7.

2 Fustel de Coulanges, L'alleu et le domaine rural, 79-87. 
slave among both the Romans and the Teutons was always an object of property. He could be sold, leased, or given away. $\mathrm{He}$ could not inherit, even if his parents were free. He might have a peculium as a reward for special industry, but the possession of this was not guaranteed by law. It belonged to the master, though usually left in the possession of the slave or his children. ${ }^{x}$ The beginnings of serfdom were found only in the later days of the Empire, and then only the beginnings. Rome knew only personal slavery to the master. The slaves worked in gangs upon the land of the master; whereas, the later serfs never worked in gangs, though groups would work in common on the lord's strips or demesne. Until a late period, the Romans did not learn that it might be more profitable to permit each slave to work on a separate lot from generation to generation. When immense territories were conquered, the Romans were embarrassed with them, not knowing how to make the ancient inhabitants cultivate them as serfs. Something approaching serfdom was gradually introduced among the Romans. Here and there, a reliable slave would be permitted to work alone on the same lot year after year, under the orders of the overseer, and would be allowed to enjoy a proportion of the fruits of his field. Good servants frequently came to have such a peculium. Gradually the jurisconsults came to speak more definitely of servile tenures and to mention the slave farmer as a quasi-colonus. ${ }^{2}$ Between a master and his slave no contract could be made to bind the former to regard such a tenure, but the tacit understanding tended to perpetuate itself in the interest of both parties. The slave was still in personal servitude, but was permitted to cultivate a particular field instead of working in a gang. Still, a large number of slaves were usually continued under the old method. The legal status of the slave was unchanged. He was still personal property, and could be returned to his old position or sold from the domain at the pleasure of his master. But since the master would usually find it to his interest to allow the slave to continue to cultivate under

Coulanges, op. cit., 290-98.

- Ulpian, Digest, xxxiii, 7, 12. 
this new condition and to permit the son of the slave to enjoy the same privileges, the servile tenure became practically permanent. ${ }^{x}$ In the course of time, the government came to regard this tenure as permanent, and legislated to prevent masters from detaching slaves from the land. ${ }^{2}$ The fiscal arrangements of the Empire strengthened this tendency. Such slaves came to be attached to the land rather than to the master; but the proportion of slaves who continued to work on the reserved lands in gangs remained much greater than the other class during the entire Roman period. Only the germ of serfdom was found in Roman society. ${ }^{3}$

Industrially the condition of the freedmen did not differ greatly from that of the better slaves. Among Romans and Germans alike the freedman could not be regarded as completely free. ${ }^{4}$ As enfranchisement depended entirely upon the will of the master it did not seem possible that such a change should remove the obligations of service altogether. The time, money, works, of the freedman belonged to the master, and the latter could sell, lease, or give away his rights in the freedman. ${ }^{5}$ Among the Germans also the freedman was little better than a slave. ${ }^{6}$ Some time after the conquests, the freedmen were found working under the conditions above described as those of the better class of slaves. In so far as he was used in agricultural labor among the Romans -he was usually employed at other service-he doubtless occupied a similar position.

There were also in Roman society many freemen who cultivated the land of others. These farmed under-contract, usually for a period of five years, though the contract could be renewed from year to year by the farmer remaining on the land without opposition. The contract was not broken by the death of either party or by the sale of the domain. The farmer was attached to

I Coulanges, op. cit., 50-56.

2 Justinian Code, xi, 48.

3 Coulanges, op. cit., 57 .

4 Wallon, Histoire de l'esclavage dans l'antiquité, II, 386, $3^{87}$.

5 Ibid., $397 \mathrm{ff}$.

6 "Liberti non multum supra servos sunt."-Tacitus, Germania, xxv. 
the soil, as under serfdom, but only for a term of years. While the contract was in force, the law would compel him to keep his agreement. The farmer, however, was free, for a contract among the Romans always implied two free persons. In practice, however, the farmer, though free, occupied a very inferior position. His work was under the direction of the superintendent of the domain, who was usually a slave or freedman; and he suffered all of the disadvantages that the weak must always suffer in getting contracts with the powerful enforced. ${ }^{x}$

The legal name of the small free farmer was conductor, but he was commonly called colonus. In time he became a colon in fact as well as in name. He lost his freedom to leave the land he cultivated. This change took place gradually, and was only later legalized; but before they were legally attached to the soil, many of the colons could be held by the landowners because they had become debtors. The masters were the more anxious to hold the colons, because the completion of the Roman conquests had cut off the supply of slaves. In a constitution of Constantine (332) the colons were recognized as permanently attached to the soil. The colons could not be separated from the soil against their wishes, nor could their rent be increased. The tendency to make certain slaves quasi-colons, as indicated above, became more marked when the scarcity of labor rendered the slaves' physical well-being an object to the master. A law of Valentinian I (377) forbade the sale of these slaves apart from the land, thus rendering their condition and that of the colons almost identical. ${ }^{2}$ The free cultivator could neither be ejected from the villa nor leave it himself. Yet the colon did not become a slave. He had a family, could inherit property, and could secure the protection of the courts against his master. ${ }^{3}$ He could not be made to perform personal services for his master, as the ordinary slave could be required to do.

I Coulanges, op. cit., 6I-68.

2 Ingram, $A$ History of Slavery and Serfdom, chap. iv, passim.

3 Justinian Code, xi, 47 (I3 and 23), 50 (I); Theodosian Code, v, I I (I), xii, I (33). 
The status of the colon was fixed by the practices of the master and the requirements of the Empire. Both the master and the government were interested in securing the cultivation of the soil; and the colon system seemed the most legitimate and the most certain to assure the cultivation. The fiscal arrangements of the third and fourth centuries helped to fix the condition of the colon. Proprietors were bound to pay the capitation tax of free peasants employed on their domains as well as that of their agricultural slaves. As the interests of the government and of the proprietor were to restrain free laborers from leaving the soil, the latter were attached to the soil and sank to the condition of serfs; and the government having an interest in preventing proprietors from withdrawing slaves from agriculture, the latter arose to the condition of the serfs. ${ }^{x}$ Thus, the tendency during the later years of the Empire was to depress the free peasant by preventing him from leaving the soil and to raise the slave by making his servitude impersonal and by attaching him to the soil. Work in gangs was still common among the Romans, but tenures were increasing. In various sections conditions varied; but one rule existed everywhere: conditions once established were not to be changed. The proprietor could not exact more from the colon than he had exacted from the colon's father. When a colon improved the soil by his labor, the benefits accrued to his children, since the rental could not be increased.2

Among the semi-servile lati who had been forced to settle on the vast Ager publicus of Gaul the same tendencies were found. The fiscal officers who had charge of these domains assumed a manorial lordship over the lands assigned to their care. To escape the exactions of these officers the farmers frequently placed themselves under the protection of powerful neighboring proprietors by commendation; and these lords could defy the officials. The farmers would surrender their holdings to the wealthy noblemen, immediately receiving them back to be enjoyed during their lifetime. These holdings thus became tenancies at the

I Finlay, History of Greece from the Conquest by the Romans, I, I53, I54.

a Coulanges, op. cit., 78, 79 . 
will of the lord, but the farmer's children were usually allowed to hold the same tenure. These cultivators, whether remaining under the arbitrary imperial officers, or escaping from their exactions to become tenants of neighboring private landlords, thus fell into the position of colons. ${ }^{\mathrm{I}}$ Everywhere the exigencies of cultivation and of the government's treasury were producing a system very similar to that which we find in the Middle Ages; but the condition of the agricultural laborers was less free than it became later, because the Romans had long-established methods which tended to bind the workmen, and skilled superintendents who could keep them in control. A great change had come over Roman agriculture since the days of Cato and Columella when the domain was cultivated by slaves working in gangs for the sole profit of the master, only a few colons occupying small lots in severalty. The proprietor had found that better results could be obtained by giving the slave a small lot to cultivate, a portion of the produce becoming the slave's peculium. This plan was also pursued with freedmen, and most frequently with colons. The Roman proprietor reserved a portion of his estate to be exploited for himself by his gang of slaves, or by the days' labor due by the tenants on the other part of his domain. All of the laborers were under the direction of the lord's villicus, who, with all other officials, was a personal slave or freedman of the lord. It seems that this was considered a kind of work which only the personal representative of the lord could satisfactorily perform. Everywhere the manorial system was in process of formation, though it can not be said that it was ever brought into complete existence among the Romans.

\section{TEUTONIC AGRICULTURAL METHODS}

We have already seen that the Teutonic tribes had been obliged to begin a somewhat intensive system of agriculture when a check was placed on their wanderings by the Roman barriers. Still, their land was in general so poorly adapted to agriculture and their habits so non-industrial that their methods of cultivation

× Seebohm, The English Village Community, 280-82, 300-311. 
could receive relatively little development until they came in close contact with the Romans. The earlier German agriculture was carried on on a communal basis. ${ }^{x}$ That the Germans had lived in free village communities can not be doubted. Even if we had none of the important direct evidence of the fact, a comparative study of all other peoples in a similar stage of culture would convince us that such was the case. This contention of the "Germanists" can not be disputed, but it does not prove their pointthat the institutions of mediæval Europe were simply the outgrowth of Germanic village life. Long before the invasions, changes were taking place in the agricultural methods which were revolutionizing the communal institutions. Land was being occupied for a long period of time, and was passing into private ownership. When pure nomads, the tribes had not, of course, anything resembling private property in land. ${ }^{2}$ As semi-agriculturists, they cared for only such control of the land as would secure the limited supply of agricultural products needed for their support. With their enforced settlement within limited areas, and with the change of the communal institutions necessitated by constant strife, lands passed into private ownership, and even into the possession of a few of the more powerful families.

The earlier agriculture had doubtless been entirely in the hands of the women; but with the introduction of slavery, the slaves were compelled to attend to most of the agricultural work. So long as society was organized on a militant basis, the freemen could pay little attention to industrial pursuits. The barbarian master gave no more attention to the direction of the work of slaves than he had given to the work of women. The former were simply brought in to assist the latter. The labor had to be performed; but how it was performed was not a matter of interest to the freeman. From the time of Tacitus agriculture was an important industry among the Germans, and was carried on by

I Supra, 83-87.

2 "When grass was as plentiful as fish, the human race treated the respective elements in which these two commodities flourished very similarly."-Garnier, Annals of the British Peasantry, $\mathrm{x}$. 
slaves on lands which were passing from communal to family ownership. The land was still the least valuable of possessions, for it was likely to be changed from time to time. The real wealth of the tribesman consisted in his cattle and slaves. The individual or family control of land was beginning, but it was only after the migrations had ceased that its importance could become marked. When a new tract of land was taken possession of by the tribe, it was divided among the households, and each household ploughed up a portion of its grass land, periodically shifting the fields, but simply to allow a part that had been worked to recuperate as grass land for future cultivation. ${ }^{x}$ The free tribesmen scattered over the tract selected by the tribe, "dwelling apart and scattered, as spring or field or grove pleased them." The slaves of the tribesman dwelt in a village on the lands controlled by him, each having a house and family. They farmed for the master, not in gangs, as the Roman slaves of Tacitus' time did, but somewhat as the Roman colons did, giving to the master a portion of the product. Domestic service was usually performed by the freeman's wife and children. The German servus was practically equivalent to the Roman colonus. ${ }^{2}$

So long as the tribe remained in one place, this arrangement continued. It had many striking points of resemblance to the Roman villa. However, the estate was usually held by a household, rather than by a single lord. This made no particular difference in the internal economy until the tribal household had to be subdivided, say in the third generation, when, of course, the holding had to be subdivided also. When land was no longer plentiful, these subdivisions could not be carried on indefinitely, and, therefore, the land would tend to pass into the hands of a single lord, the subordinate members of his family becoming dependent upon him. These freemen who were no longer able to maintain their equality were the more willing to take a subordinate position, because the tribes were organized on a permanent

x Cf. Seebohm's comments on Germania, xvi, op. cit., 342-45.

2 Tacitus, Germania, xvi. Cf. also ibid., xxv; Grimm, Rechtsalterthümer, $35 \circ$. 
military basis which, as we have seen, took the form of the comitatus. When the whole tribe migrated, a new distribution of lands took place; but after the new settlement had been established, things went on as before. When the tribes could no longer migrate beyond the Rhine, they broke into the Empire and secured new lands there.

The settlement of a tribal household was designated by a patronymic ending in -ing. Where tribal households had broken up and a single lord had come to hold the lands indefinitely-a condition of things found only where the Roman influence was strong-the estates bore names ending in -ham or -heim, the suffix -tun also being found in Britain. When, finally, some of the estates held by tribal households passed under individual ownership, they were called both -ings and -heims, as -ingham. These words indicating individual ownership had the same significance as the Latin villa. They were frequently used interchangeably with that word in the earlier records of manors. The barbarians themselves would frequently Germanize the Latin word weiler and apply it to the same estates which bore the name -heim. ${ }^{\mathbf{x}}$ Wherever the tribes entered upon a settled mode of life, the agricultural organization took on some of the features of the Roman villa; and when they were brought into very close contact with Roman settlements, their estates became almost exactly like the villas. The manorial organization of later times can not be said to have existed among either Romans or Germans, but similar conditions among both peoples were causing like developments tending toward the manorial type. It must be remembered, however, that the Teutonic cultivators always worked on shares, the reserved portion of the domain worked by gangs of slaves never being found, except, perhaps, in a few instances where the German lord had been wholly Romanized.

The manor-in embryo-was, in fact, already in course of development. The German economic system was, to say the very least, working itself out on lines so nearly parallel to those of the Roman manorial system that we can not wonder at the silent ease with which, before and after the conquest

× Seebohm, op. cit., 253-62, 346-62. 
of Roman provinces, German chieftains became lords of villas and manors. The two systems, Roman and German, may well have easily combined in producing the later manorial system which grew up in the Roman provinces of Gaul and the two Germanies. ${ }^{x}$

When the Germans entered the Empire and took possession of the Roman estates, they readily adapted themselves to the system they found there. Their own system of servile cultivation so closely resembled the Roman colonate that they not only allowed the latter to remain, but even extended it to take in the whole servile population. Personal slavery was useless to them and soon disappeared. The demesne was cultivated, largely at least, by the same laborers who were working other parts of the estate on shares, their services to the landlord being rendered as rental for their holdings. The old terms which had designated various classes of servile laborers long remained, but they all came to be applied to persons of one class. A few slaves may have remained for some time in non-agricultural service, but immediately after the invasions the greater number of slaves became serfs. Domesday Book shows that the servi constituted but 9 per cent. of the population of England, and by far the greater number of these were in the west and southwest where the manorial system was least advanced. Within a century after the conquest by the Normans, these had entirely disappeared. The Roman servus remained a personal slave down to the last; and yet, if the Empire had stood a few centuries longer, it is possible that the necessities of more intensive agricultural methods would have led to a loss of that complete control of the laborer's activity which was characteristic of the whole Roman period. When the laborer is given freedom to pursue his own methods, he has advanced far toward legal freedom. However, the methods of control which society exercised must have continued to hold the laborer in a servile condition. But the barbarians were unable to control their slaves as the Romans had done. They had possessed slaves for a long time. These were conquered tribes or individual captives, prisoners for debt or for lost wagers. They

I Seebohm, op. cit., 346. 
had no civil rights, but the simple conditions of German life, requiring no great division of labor, had made an extensive slave system impossible. Some slaves might be required to perform domestic drudgery, but the greater number cared for the flocks and herds and cultivated the fields somewhat after the manner of the later serfs. When the tribes became relatively settled and the tribal families scattered, as described by Tacitus, the slaves became villagers, carrying on their industrial pursuits with little interference from their masters, while the latter devoted themselves to war and the chase. If any of these tribal households possessed no slaves, it is perfectly possible that they may have remained practically free village communities for a time, the freemen cultivating the fields which they owned in common: But this condition of affairs could not last very long; for the tribal household would either get slaves or perish when the military movements became common, since only a slave-holding people could maintain an efficient military organization and secure the supply of its economic needs. Possibly the -ing would pass into the hands of a chief, the other freemen becoming soldiers and receiving their support from the chief. In this case, the -ing would have become a -heim. Whatever the organization of the free-men, the servile population occupied a position analogous to that of the Roman colons, and it was easy for the German chieftain to turn over the agricultural labor to the slaves and colons already on the conquered domains, and thus to strengthen the tendency toward an impersonal serfdom already going on within the Empire. The development toward the mediæval manor was most marked where the tribes came in contact with the Roman domains; and, naturally, the agricultural organization found on the conquered lands did not need to be greatly disturbed. It was not greatly disturbed in its external aspects, though its efficiency was greatly lessened.

\section{THE FEUDAL SYSTEM AND AGRICULTURE}

The vicissitudes of the invasions favored the destruction of the last vestiges of the old tribal organization and the develop- 
ment of feudal institutions. Conditions favorable to communal ownership of land had ceased to exist in many sections long before the invasions. When the chiefs and their men of war settled down on the conquered estates, there was absolutely no possibility of communal ownership. Either the land would be divided among all the members of the company, when each tribesman would have a domain on which he could exploit the provincials who fell to his share; or the chiefs would appropriate all lands, supporting their men in return for military service, and requiring the servile population to carry on the agricultural work. In a society organized principally for military purposes the latter arrangement would seem to be the more natural one, for the freemen had to be kept under arms. There was no place for the free village community, since the common soldiers formed something like the comitatus when they conquered and held the Roman lands. Even in the earlier days, those who were members of the comitatus were withdrawn, for the time at least, from the tribal village. Undoubtedly, so long as the tribal village lasted, the assembly of the whole people settled all important matters, only affairs of a routine nature being left to Gaukönigen and Gaugrafen. ${ }^{x}$ The Marcomanni, Lombards, Franks, and Anglo-Saxons had no kings in their earliest historical period. The military leader had been a temporary functionary, frequently chosen by lot. But the movement of the tribes and the constant struggles with organized forces required constant leadership. The popular assembly became impossible. A tribe which could not organize a strong military government could not survive in the struggle for existence. The war-chief had to become permanent when war was incessant, and he could easily extend his power from supreme command in the field to supreme command in all things. Only once or twice did the army attempt to check Clovis; and after the conquest of the Frankish empire no gathering of the nation was possible. ${ }^{2}$ Clovis was already a king with some-

I Wietersheim, Geschichte der Völkerwanderung (Dahn ed.), I, 38, 67, 216, $53 \mathrm{I}-34$.

2 Oman, The Dark Ages, I21, 122. 
thing like despotic powers. His chiefs were military leaders who continued to exercise their profession, becoming during the period of royal weakness almost independent monarchs. During the whole Merovingian period, it was practically impossible to disband the armed companies and form settlements in village communities. The agricultural processes had to be carried on by the subject population, and the military organization prevented any general distribution of the common soldiers upon small estates. Nor did the latter settle in self-governing villages on the estates of their chieftains. They became men-at-arms under the new order of things. The industrial life was not essentially changed by the migrations. The freemen had not worked before; they were not likely to do so after they had made a move which was intended to better their condition. The change meant simply that there had come to be one master of a large number of slaves, instead of many masters of small groups. The common freemen now depended upon this powerful chief for their economic needs. In general, it may be better to regard the Roman system as continuing, modified by Germanic customs; rather than the German customs as being carried over, simply modified by the Roman system.

These facts will appear more clearly as we take up in some detail the development in the three or four main sections into which Europe was divided. In what follows, either the more striking characteristics of the development in the respective sections, or those features which were common to all sections, but which have been fully discussed with reference to a particular locality, are presented as arising in this or that division of Europe; but it must be understood that all these are parts of one whole. Italy shows certain aspects of the disintegrating tendency; England, where the Danish and Norman conquests followed the Saxon, remained in a backward condition long enough to enable us to gather certain information regarding the status of various classes of men and the prevailing methods of agriculture, that we do not find elsewhere; while on the Continent north of Italy the main movement of mediæval history went on and feudal institutions received their typical development. Italy is treated briefly, as lying 
somewhat outside of the real life of Europe; England is treated next, because some of the facts brought out in the discussions concerning the English development help us to a better understanding of the matters which claim our attention when we take up some larger movements on the Continent. Neither geographical nor chronological considerations justify this order, but it appears convenient to the author; and, it may be added, it is only because of his inability to make a satisfactory generalization of the whole movement, that the discussion is narrowed by geographical or local historical treatment.

Italy.-In Italy, where the resistance to the Lombard invasion was very slight, or at least not concentrated, and where external foes did not compel a constant effort on the part of the combined forces of the invaders, society immediately split up into many small principalities. No central government was possible after the death of Alboin. Each duke was a monarch in his petty dominions. The Lombards were too barbarous when they invaded Italy to regard themselves as a nation or to comprehend the value of a centralized government. 4 The king was only a war-leader; and after the first march was accomplished, they no longer felt the need of one. Yet conditions did not admit of the continuance of primitive Teutonic habits. The different tribes were so constantly at war with one another and with the Roman cities that the military leaders became absolute rulers. By the end of the sixth century, the Lombards had all received Christianity, had settled down in their new homes, and were beginning to build churches and castles. ${ }^{\mathrm{x}}$ But by this time of settlement, the primitive organization had been too long disrupted and the power of the dukes too long maintained, for a return to the older customs. The military organization was kept up, though no nation could be consolidated. No vestige of free village communities or of government by the assembled freemen remained. ${ }^{2}$

Oman, op. cit., 195 .

2 The Edictum Rotharis, a very early code formulated in 643 , defines the duties of men to their lord, describing barones, men. and aldiani, but no independent freemen except nobles. It indicates that the people dwelt apart on individual or family estates. 
The lands were divided among the conquerors. The dukes sought to secure strongholds where they might rule with absolute authority. The want of vigor of the sovereign power compelled many minor lords to accept the position of vassals to more powerful neighbors who could protect them, while the difficulty in enforcing authority over wide territories compelled the great lords to cede a part of their lands in benefice to lesser vassals who might be of some benefit to them. ${ }^{x}$ Thus, the chief men, the milites, of a duchy obtained estates subject to the authority of the duke; while the king had a sort of fictitious authority over the duke on the ground that the whole territory was royal property. But "since the stability of power held to territorial wealth, the power of the gentlemen over their subordinates was absolute, that of the dukes precarious, and that of the kings practically nil." 2 The chatelain nobles were vassals of the duke and vavasseurs of the king, yet they were practically independent on their estates. Their pleasures were in arms and the chase. They were strangers to all arts and luxuries; and their castles, though impregnable, were devoid of all ornamentation. The next in order below the nobles were the arimanni. These were freemen, probably the better class of the old inhabitants, who owned, or had owned, some allodial land, but who cultivated some of the land of the seigneurs. They occupied an inferior position, but had a right to trial in the courts. Below these were the masnada, who were probably the rank and file of the Lombard freemen who had been unable to secure estates of their own. Had any of them received estates, they would have been obliged to surrender them to some powerful neighbor and receive them back in vassalage, in order to secure protection. These held a portion of the seigneur's land by military tenure. If their holdings were of importance, they must have had slaves under them; otherwise, they could not have cultivated their land and at the same time have rendered the constant military service demanded of them. If their holdings were mere garden-plots, they may have been able to devote a little time to them, while

I Villari, The Two First Centuries of Florentine History, II, 39, 40.

2 Sismondi, Histoire des républiques italiennes, I, 64. 
doing garrison duty, and might have left them in charge of their families when away from the domain. If however, as is more probable, they received their holdings after the military operations became less constant, they could cultivate their own fields, rendering to the lord occasional military service in lieu of labor or other rent. The third of the lower classes was composed of the aldiani, men who had been born slaves or had been reduced to that level when Italy was conquered, and had exchanged their absolute dependence for tenures in villeinage. The slaves formed the last order of society. Some of these cultivated their own lands, remitting a portion of the products of their labor to the seigneur; others were in absolute dependence, and labored on the undivided lands of the estate. But the condition of all slaves was better than it had been under the Romans. Many Lombard laws protected them from unjust or very severe masters; and though these laws were not always enforced, they indicate a higher standard than that which prevailed among the Romans. Slaves who sought the church were assured of protection. The Lombards were the most barbarous of all the Teutonic invaders, and did little to advance civilization; but the fertile fields of Italy and the subservience of the remaining population of the conquered territory gradually modified them, and they settled down to the care of their estates. Such of the former inhabitants as had not fled to the few remaining cities became cultivators attached to the soil to which they gave value. The Roman methods of agriculture were carried over by the cultivators, and abundant harvests were secured much earlier than was possible in other parts of Europe. ${ }^{x}$

Here, as elsewhere, the barbarians had no accumulated capi-' tal, no commerce, no ability to sustain themselves except by the produce of the conquered lands then cultivated by the conquered population. The necessities of military life compelled the Lombards to organize their military power on the basis of the duchies;

× Cf. Sismondi, op. cit., I, 60-75. "L'esclavage des campagnes romaines dépeupla l'Italie sous les empereurs: l'esclavage de ces mêmes campagnes ne les empêcha pas de se repeupler sous la noblesse féodale."-Ibid., 75. 
but the immediate authority over the population could be exercised only by the seigneurs. Ownership of land and sovereignty became mixed in the barbarian mind; and since real political authority could be maintained only on the land controlled by the lord, the higher political organization which had to be held together for great military exigencies was regarded as based on a fictitious ownership. The duke could exercise actual authority only over the lands directly controlled by him. Therefore, he had to convey the rest of his lands to lesser chiefs, in the hope that the latter would usually render him some service when he needed help. This hope, however, was seldom realized, except when it was to the interest of the vassal to co-operate with his duke. If a duke should reduce a rebellious vassal, he could not permanently hold his estate, for he already had all he could control. If he gave the estate to another vassal, he would be no more sure of fidelity than before. The dukedom or province was thus split up into domains, and the real political power resided only in the master of the domain-where the economic power resided. Such domains as were too small to stand alone, because they could not support a force that was able to defend them against ordinary attacks, were gradually absorbed by the larger neighboring domains, first as dependent but still maintaining their integrity, later as integral parts of the great domain. If a domain proved too large for its master to control it by means of the very crude administrative machinery at his disposal, he was obliged to divide it. Few domains were likely to be too large; but frequently a lord would possess several domains. If these were too scattered for his immediate control to be exercised, he was compelled either to exchange some of them for others lying more closely together, or to grant those farthest from his main domains to some other lord. In any case, the control of the lord was of a semi-political character. The land was actually in the hands of the only people who knew how to use it - the serfs, some of whom may have been the former masters. The dukes differed from the other nobles only in having larger estates and therefore a greater command of resources which enabled them to assert their power. 
Charlemagne attempted to bring all the petty units into one great whole; but in Italy, as elsewhere, he failed to accomplish his purpose. The unity for which Charlemagne stood could not be realized until further progress had been made in the industrial life of these little domains. The welfare of humanity demanded the division of Europe into petty communities. Charles only succeeded in creating a new nobility. His object was to have a personal representative of the crown placed over each minor division of the empire. These representatives were his counts. Except on the borders where greater power was nceded for protection, the great duchies, thirty in number, were split up into many counties; and by the time of Charles le Gros there were only five or six nobles left who were powerful enough to dispute for the crown. Yet while the power of many of the great nobles was broken, Charlemagne did not succeed in establishing the royal power through his counts. These counts, though appointive officers, soon came to have great personal power. They had been put in possession of estates, either by direct gift or as stewards of royal domains. The practice of allowing a son to succeed his father in this office soon became unavoidable, because the king could not support his count by military force, except on rare occasions, and the only men of the provinces who had sufficient resources to maintain themselves as counts were the very ones who received the landed power from the king. It was only as a man was a great seigneur that he could serve as count, and the lands that had been given or intrusted to a count by Charlemagne were pretty sure to be held in his family. When a vacancy occurred, the king or emperor was obliged to appoint the heir of the late count, or undertake to put in a new count by force." Even if the latter course could have been pursued by the decaying royal power, the new count could not have maintained himself unless he had been put in possession of ample domains. If this were done, the new count would be in the same position as the old one, and would exercise authority simply as the most powerful seigneur of the district. No standing army could be maintained by the central authority to enforce its claims, because the 
food supply was not sufficient to support one, nor the roads and shipping facilities adequate to its mobilization. The only organization which could furnish at once a food supply and a standing army was the domain. No central power, even if exercised by a succession of Charlemagnes, would have been able to provision an army, except on the rare occasions when the mass of the domanial lords might find it to their interest to support the central power against a common foe. Thus the attempt to organize the empire in such a way as to keep the hands of the emperor upon all sections at the same time resulted only in putting counts in the place of dukes. The political power was left still weaker than it had been before, and was brought to correspond more completely to the domanial power. The hereditary counts were accepted regularly soon after the death of Charlemagne, and their regular succession without special royal confirmation was legally authorized by Conrad the Salian in the early part of the eleventh century. They kept alive some shadow of the royal authority, but the increased disintegration caused by the Hungarian and Saracen raids of the ninth and tenth centuries compelled the nobles to fortify their castles more strongly and to make their domains more entirely self-sufficient. The real authority of the counts practically disappeared. The feudal system was fully established in all parts of Italy which had fallen into the hands of the barbarians.

England.-In England the conditions for some time after the Anglo-Saxon conquest were similar to those in Italy. The country was slowly subdued, but no organized opposition was offered and no external foe threatened the newcomers. It was unnecessary for them to establish a strong form of government. Because they were not compelled by external pressure to form such a government, they did not attempt to do so. The tendencies toward separation were so strong that they could not do so. Yet a military organization had to be kept up, and the settlement of all classes in industrial pursuits was indefinitely delayed. When the British were subdued, the tribes began to fight among themselves. As in Italy, the majority, at least, of the common freemen 
had to be kept under arms. Economic wants were supplied either by slaves imported from Germany or by the ancient inhabitants. The same causes which elsewhere led to the formation and maintenance of an organization resembling the comitatus were operating here. The fact that the invasion was by water did not change the general condition of things. When, however, the Normans invaded England, the stubborn resistance of the English and the constant danger of uprisings that might overwhelm the comparatively small number of conquerors, compelled the Norman barons, powerful and unruly though they often showed themselves to be, to support the royal authority and to subordinate their own interests to it. Not until the time of Stephen could the nobles afford to split up the kingdom. At that time, the fear that the Earl of Gloucester, then in Normandy, might espouse the cause of the princess and invade England, led Stephen to make concessions from the royal domains to the rebellious nobles.

The English agricultural system had its beginnings far back in the Celtic and even pre-Celtic tribal communities. The communal methods of agriculture did not differ materially from those found in Germany or countries where the people were in the same stage of culture. The earlier Celtic invaders had doubtless taken little part in the cultivation of the soil, exercising but a general lordship over the conquered communities. ${ }^{\mathrm{I}}$ But later the invaders seem to have settled down to agricultural life. The whole population, however, retained semi-nomadic habits, except in the southeast, where later immigrants from the country of the Belgæ had carried many of the customs of Gaul. ${ }^{2}$ Most of the tribes would migrate frequently,' whenever their lands became impoverished, and would plough up new land. Wherever permanent settlements were made, the open-field system prevailed. In pre-Roman Britain this openfield system may have been a one-field system, as was the case in those parts of Germany which were least influenced by the Ro-

I Gomme, The Village Community, 70-72.

2 Cæsar, B. G., v, 12, 14; Beddoe, Races of Britain, $23,42$. 
mans. ${ }^{x} \quad$ But if the population had become dense enough to check migrations, some system of rotation would have been introduced in time, even without contact with Rome. The semi-nomadic habits were checked by the Romans even in those sections which were least directly under Roman control. From the time of the Roman invasion there was a steady improvement in agricultural methods, the most important change being the introduction of a three-field system similar to that found in those parts of Germany which bordered on the Empire. This system provided for a regular rotation of crops, wheat being raised on one field, oats, or beans on another, while the third would lie fallow. There was no more ploughing-up of new land one year, which would be allowed to go back to grass as soon as it began to become impoverished. In neither the Welsh nor the German tribal cultivation was this three-course rotation found until the beginning of Roman influence. The change was necessitated both by the check upon nomadic habits and by the increasing demand for agricultural products for domestic and foreign consumption. ${ }^{2}$ Whether the Britons and the Germans learned from the Romans the advantage of crop-rotation, as Seebohm suggests, or were forced, by reason of their more stationary life, to go back repeatedly to fields which they had abandoned until experience had taught them that a three-course rotation was the most economical, is a point which can not be definitely decided. Probably both causes were operative. As in Gaul, the Roman conquest put an end to intertribal wars, and made possible the development of trade and industry. "The Roman roads likewise promoted these interests. Exports of wheat, minerals, cattle, and slaves became important; ${ }^{3}$ and with increased demand for agricultural products there was, of course, an increased stimulus to more intensive cultivation.

Aside from the check on the migratory habits of the Britons, the introduction of rotation of crops, the importation of new

x Seebohm, op. cit., 373, 4ro.

2 Ibid., 41 1-13, 4 I7.

3 Gibbins, Industry in England, 31, 32. 
plants, and the benefits of the Pax Romana, there is little evidence that the Romans had much influence in shaping the British agricultural organization. ${ }^{x}$ Britain was very different from most other Roman provinces. The country was more like a military colony than a completely Romanized province such as Gaul. The population of Italy, especially after the outbreak of Asiatic cholera about $200 \mathrm{~A}$. D., was decreasing, and a sufficient colonizing body could hardly have been sent from Rome. Gaul might have spared some colonists, but there was little inducement for men to go from that province to Britain. The British legions were composed of all nationalities, and could have had little influence in agricultural matters. ${ }^{2}$ Romans were no more inclined to settle in a country with the climate of Britain than the English are now inclined to settle in India. The land offered no opportunities for making great wealth, and only military or commercial interests could draw Romans to it. Those who came for the latter reason might stimulate all industries whose products they took, but they could scarcely have much influence in directly changing agricultural methods. Over two hundred Roman stations are known to have existed in Britain, and in some sections, especially in the southern part of the island, the remains of many Roman villas have been found; but there is no evidence that the Romans directly organized the peculiar agricultural system which the Saxons found in Britain. Most of the Roman monuments and inscriptions refer mainly to military and official affairs. ${ }^{3}$ The great roads were built for military purposes. In general, the long Roman occupation was military and commercial, not agricultural and industrial, and its direct influences could hardly have touched any but the higher classes.

The Saxons, on the other hand, invaded Britain, not merely as temporary office-holders, but as permanent settlers. They spread over the whole country and assumed complete possession of

× Contra, Ashley, Introduction to translation of Coulanges' Origin of Property, xxiv-xxvi.

2 Andrews, The Old English Manor, 34, 35.

3 Gibbins, op. cit., 22, 26. 
everything they found. They were a wholly barbarous people, never, probably, having come in contact with civilization until they landed in Britain..$^{x}$ Coming as settlers, however, they were not mere destroyers. Much destruction doubtless resulted from the invasions, and those who actively resisted the newcomers, especially among the higher classes, were certainly slain. But the opinion so long held, ${ }^{2}$ that the original inhabitants were either slain or driven into Wales and Scotland, must have arisen from too unquestioned acceptance of the prejudiced accounts of ecclesiastical writers like Bede and Gildas who could see nothing but ruin in the conquests of the pagan Saxons. ${ }^{3}$ The destruction of the rulers and landowners was not inconsistent with the preservation of the mass of the peasants. Indeed, a people which had never engaged in industrial pursuits at home, but which had depended upon the labor of women, the infirm, and slaves, would be very anxious to preserve a large body of those laborers whose continued activity would satisfy their ordinary wants. After the long desultory wars which laid the country desolate, the invaders settled down to enjoy the fruits of the labors of the surviving Britons.

After the sanguinary barbarians had secured their dominion and gratified their revenge, it was to their interest to preserve the peasants, as well as the cattle, of the unresisting country. In each successive revolution, the patient herd becomes the property of its new masters; and the salutary com. pact of food and labor is silently ratified by their mutual necessities. . . . . The kingdom of Sussex, which spread from the sea to the Thames, contained seven thousand families; twelve hundred were ascribed to the Isle of Wight; and if we multiply this vague computation, it may seem probable that England was cultivated by a million of servants, or villeins, who were attached to the estates of their arbitrary landlords. ${ }^{4}$

I Seebohm's theory that the Anglo-Saxons came from South Germany, where they had long been under Roman influence, seems incredible to me. Not only would such people be unlikely to become navigators so quickly, but the whole movement of the tribes in that section was in the opposite direction. Cf. Andrews, op. cit., 32 .

2 E. g., Stubbs, Constitutional History, I, chap. iv.

3 Pearson, History of England, I, 99-ror; Gibbins, op. cit., 35.

4 Gibbon, Decline and Fall (Millman ed.), III, 358. 
The outcome of the invasion, so far as the agricultural organization was concerned, was that the peasants became a class of servile dependents, and were compelled to carry on their old methods of cultivation for the benefit of their new masters. Since they had come in large numbers for permanent settlement, the Saxons brought with them their families and slaves. The latter could not have been very numerous. The simple conditions of Teutonic tribal life did not permit of an extensive slave system, and the method of invasion did not favor a wholesale importation of slaves. Yet the usual method of employing slaves described by Tacitus was doubtless in vogue among the Saxons and prepared them for the servile system which finally developed into the manor. What the Britons contributed was a body of trained agriculturists whose three-course rotation of crops represented a marked advance in efficiency over the agricultural methods which had prevailed among the Saxons in north Germany. There, the one-field system of cultivation had been employed.

This original population, reduced to servitude and supplemented by the slaves brought from Germany, constituted the industrial class. It was employed at the only industry that could then be of material importance to the barbarians - the production of a sufficient supply of food. It must be remembered that the Saxons, like the other barbarian invaders, were obliged to maintain a military organization, since each tribe had to defend itself against its neighbors and all were obliged to carry on wars for a long time against the Britons on the north and west. This meant that the Saxon freeman could not have settled down to industrial pursuits, even had he been disposed to do so. Here, as elsewhere, the demands of military operations tended to increase the power of the chieftain and to depress the condition of the common soldiers.

Even some of the advocates of the theory of a continuance of free village communities composed of Germanic tribesmen recognize the necessity of a military organization at the time of the invasions. Kemble, in explaining differences in rank among the 
freemen, says: "There can be no doubt that some kind of militaly organization preceded the peaceful settlement, and in many respects determined its mode and character."x This statement agrees with the argument made in this essay, that the old tribal organization was bound to give way to something like a permanent comitatus when migration and constant warfare rendered the former inefficient. Earle explains the presence of a powerful captain in what he claims to be a free village community in the following manner:

Of all principles of military regiment there is none so necessary or so elementary as this, that all men must be under a captain, and such a captain as is able to command prompt and willing obedience. Upon this military principle I conceive the English settlements were originally founded, that each several settlement was under a military leader, and that this military leader was the ancestor of the lord of the manor. ${ }^{2}$

Of course, such a military organization bears little resemblance to a village community; and if it should rontinue for any considerable length of time-and in England it must have continued at least a century-it would be impossible ever again to return to the earlier tribal organization. Indeed, when this military leader is regarded as the ancestor of the lord of the manor, we have an admission that there was no return to the earlier type. In the old tribal organization everything was governed by habits which had gradually developed. Many of the tribal customs could not possibly stand the social dislocation to which they were subjected by the migrations. A strong military organization maintained for several generations must inevitably have resulted in the development of habits of leadership, on the one hand, and of obedience, on the other, which were wholly unknown in the tribal community in Germany.

It may well be doubted whether there was, at first, a consciousness of the increased power of the individual will of the chieftain even on the part of the chieftain himself. Under more primitive conditions, there had been little sense of individuality on the part

× Saxons in England, I, 125.

2 Land Charters, 55 . 
of either chief or tribesman. The political unit had been the community, not the free man. ${ }^{x}$ A recognition of this lack of individual freedom in tribal life, which must be apparent from the most casual anthropological observations, would have saved a great deal of discussion concerning the free mark and its place in the development of modern institutions. The tribesman is always under bondage to tribal customs and institutions; and although his chief may sometimes be chosen by election instead of by lot-both of which practices were found among the German tribes-the tribesman does not dream of asserting his individual will or of claiming an individual share in communal property. Nor does the chief, though exercising considerable authority, regard himself in any other light than as bound by tribal custom. And yet, whenever a chief holds power for a great length of time, he is likely to begin to lay plans to hold the office permanently. This is especially true when the chief must take an individual initiative because the old tribal customs no longer meet the emergency. Now, although there was undoubtedly a growing ambition among the German leaders, there is no reason to believe that they regarded appropriated lands as their exclusive and private property, or that their followers aspired to individual ownership of any part of the conquered lands. ${ }^{2}$ The leaders regarded themselves as protectors of the companies under them, and the latter looked to their leaders for direction in military affairs and provision for bodily wants. It was only a step for the leaders who assumed this position to become the strong, self-willed feudal lords of the Middle Ages, and the exercise of their new powers was bound to bring their individuality to consciousness; but it does not follow that the ordinary freeman became restive and dissatisfied under this arrangement. It is a great historical fallacy to read back into the consciousness of the invading tribesman the democratic sentiments of the nineteenth century. There is no evidence that the rank and file of

x Contra, Gibbins, op. cit., 6r, and many other writers.

2 Those who had become proprietors of heims on the Roman frontier attained their position before the invasions and are not to be regarded as the product of the new military relationship. 
the invaders ever demanded or received estates of their own. Whether free tenants or serfs, they held under the chiefs who led them to victory. The chief of each clan or kindred group assumed possession of some convenient area of conquered land, probably corresponding exactly to some existing domain or group of domains. The tribal chief retained his less direct leadership of the group of clans, assuming control of any public lands that might be in the district and appropriating private manors, if these were needed for the maintenance of the men directly under him. The chief of the clan would thus become a manorial lord, and the tribal chief would become a petty king as well as a manorial lord. ${ }^{x}$

The manner in which the free tribesmen were settled is one of the disputed points of history. It is sometimes charged that such writers as Seebohm omit this body of free tribesmen altogether, simply assuming that the invaders distributed themselves over the manors of the conquered lands and took control of the servile population already found there." There may be some justice in the charge; and yet, while writers of this school have failed to give a specific account of the disappearance of the free tribesmen, their general position is not inconsistent with the existence of that class at the time of the conquests and their distribution on the manors. Nevertheless, the impression is left that the number of invaders was inconsiderable; and one of Seebohm's critics justly asks: "Can it really be true that the great bulk of free men was originally in territorial subjection, or rather that there never was such a thing as a great number of free men of German blood, and that the German conquest introduced only a cluster of privileged people which merged into the habits and rights of Roman possessors?"3

There is every reason to believe that the number of invaders was far from inconsiderable. The traditions of the old chroniclers, the requirements for the subjugation of the natives, and

I Andrews, op. cit., 50, $5 \mathrm{I}$.

Ibid., 58; Gibbins, op. cit., 60 .

3 Vinogradoff, Villainage in England, 34. 
the fact that the language of the invaders almost wholly displaced that of the vanquished, all justify the assumption that the Saxon tribes had entered the country in great force. The free tribesmen did not become lords of manors, unless in a few isolated cases. There were about 9,250 manors in 1086; and although many changes had doubtless taken place since the Saxon conquest, the number at the time of the first distribution can not have been greatly in excess of that number. It may have been less. A part of the region covered by Domesday was not occupied by the Saxons until long after their first arrival. The evidence of the long continuance of the open-field strips and the village settlements precludes any hypothesis of a material subdivision of the manors found by the Saxons and afterward appropriated by the Normans. ${ }^{x}$ There was evidently, then, no possibility of a division of the land which would give every free tribesman a freehold to be cultivated by himself or by his slaves. While the opponents of the free-village theory may have failed to account for the settlement of the tribesmen, it can hardly be said that they have claimed that all of the invaders became lords of manors. If their position implies such a claim, it is manifestly absurd. There must have been many more than 9,000 men in the invading tribes, though there were only about that many who were of sufficient importance to become lords of manors. Indeed, it may be doubted whether a different lord was placed on each of the 9,000 manors, though there were doubtless fewer who held several manors than after the Norman redistribution.

The position most completely opposed to the one just discussed is that the tribesmen settled in free village communities and preserved a communal organization until about the time of the Norman Conquest. Beginning with Kemble and von Maurer, the free-mark theory has been persistently upheld by many able scholars both in England and on the Continent. It may safely be said that this theory, at least as applied to England, France, and Italy, can not be held today. It may be untrue that the bulk of the population of the conquered regions was made up of the

s Seebohm, op. cit., 109, 178, 179. 
former inhabitants reduced to slavery, but it is also impossible to hold that former populations were wiped out and that completely communal settlements were made by the victorious tribes. ${ }^{x}$

The chief reason for holding that the tribesmen did not settle down at once as agricultural laborers in village communities has already been suggested. They were needed as a sort of a standing army. Only by keeping up a military organization could any group maintain itself against its neighbors and carry forward such offensive operations against the Britons as might be necessary. A non-slave-holding community must have perished under such circumstances. It was necessary to maintain an organization similar to that which had prevailed in Germany, where the freeman did almost no labor, while the nature of the chieftainship kept the band together more permanently than was possible in more primitive times.

Nor is it at all likely that the tribesmen would have been willing to settle down to agricultural pursuits, even if they had not been required for military purposes. As already stated, the simple labors of the barbarian tribes were carried on by women and slaves, the freemen seldom or never engaging in industrial pursuits. These men, already familiar with servile labor and securing a sufficient supply of laborers from among the conquered populations, finding ample scope for military operations and having their fondness for war increased rather than diminished by recent experiences, would be little likely to settle down in agricultural communities unless they could have slaves under them. This last was an impossibility under the conditions existing in the conquered countries. Wherever the Aryans have gone, they have shown the same disposition to maintain their warlike habits and the same indisposition to engage in industrial pur-

I It does not seem desirable to review in full the arguments by which the opposing schools have sought to uphold their theories. Excellent summaries of the course of the discussion are given in the following authorities: Vinogradoff, Villainage in England, I-39; Ashley, "The Beginnings of Town Life in the Middle Ages," Quarterly Journal of Economics, X (July, 1896), 359-406; Pirenne, "L'origine des constitutions urbaines au moyen âge," Revue historique, LIII (September, 1893), 52-83. 
suits so long as they could compel conquered peoples to support them. All of the advantages of the culture of the conquered peoples have been accepted, and an overlordship assumed "which the older races had never tolerated as a development from their own institutions." This had been true of the Celts who had preceded the Teutons, and it was now true of the latter wherever we can find any trace of their methods. Only later could the conquerors be reduced to the necessity of working for themselves. Says a student of Aryan life:

Distinct from the comitatus or military retainers, and yet essential to the existence of that body, was the despised and non-combatant class which performed the humble duty of cultivating the warrior's fields. It may be stated, generally, that this class was composed of men outside of the kin, although dependent upon it or upon some of its members, and that it was derived from a conquered and alien race. In most of the countries whither the Aryan nations wandered, they appear to have found hostile populations of a race different from their own. Similar troubles awaited them when they journeyed east and west. So far as their history is known they always conquered, and either absorbed or enslaved their opponents. ${ }^{x}$

This indisposition to labor was intensified by the fact that the labor of the subject population could supply the needs of the barbarians more bountifully than they had ever been supplied before.

Accordingly it was not until the land had been occupied for some time that the tribesmen began to take their place in the industrial ranks. The permanent settlement of the clans, after the conquests were wholly accomplished and intertribal wars had become less frequent, did away with the need of a standing army. A nucleus had to be maintained for garrison duty; but the greater part of the Saxon freemen could well be spared for agricultural labor. Together with this release from constant military service, came a demand for increased agricultural productivity because of the increase of the population and the demand for greater comfort. It therefore became desirable that the tribesmen should become agriculturists. But the process of transformation was a slow one. By the end of the seventh cen-

searn, The Aryan Household. 
tury, it was still difficult to induce the freemen to take their places beside the servile population in industrial activities, and King Ine made special efforts to get them to do so. ${ }^{x}$ His interest in agriculture is evidence of the fact that the demand for food was being met with greater difficulty than formerly.

The settlement of free tenants on the domains could be easily accomplished without interfering with servile tenures; for there were many vacant strips in the fields after the ravages of the invasions, and there was always ample room for the extension of arable lands by clearing the forests and redeeming the waste which surrounded every settlement. The position of the freemen, when they first became agriculturists, must have been much superior to that of the other cultivators. The nature of their services can not be definitely stated; for the earliest records-for example, the Saxon version of the Rectitudines singularum personarumbelong to a period when the freemen had dropped to a completely servile condition. The many cases of free tenure cited by Vinogradoff $^{2}$ belong to a much later period, after the Norman invasion, when a great many servile tenures were in process of being freed from former obligations, rents being accepted in lieu of services; and have nothing to do with the tenures of freemen which, three or four centuries earlier, were becoming servile. In all probability, the holdings were intended to be by military tenure with, perhaps, some slight rent in kind or labor during the busiest seasons added to the military duties. The fact that the so-called free tenures were on the demesne lands indicates that freemen were induced to cultivate lands for which there were no other available laborers. If the portions of the demesne thus cultivated were scattered strips in the open fields, the freemen were doubtless set to work there because the servile cultivators were too few to cover the whole ground, either because some servile tenures had become vacant or because new strips were added from the waste. Whatever the particular methods by which the tribesmen were induced to become agriculturists, it was in-

I Chronicon monasterii de Abingdon, Vol. II, chaps. xiv, xv.

2Villainage, r66-72, 325-28, etc. 
evitable that such a change in their occupations should take place. When the lord came to appreciate the value of an increased production from his estate, as he did when the population increased or when his own advance in civilization increased his desire for things which could be secured in exchange for the agricultural surplus, and when he no longer found it necessary to keep the whole body of his followers constantly under arms, he was bound to find some means by which he could turn his men to productive activity.

Now, although the tribesmen must have occupied a superior position on the domains when they first began to assist in their cultivation, it was impossible for them to remain permanently above the mass of the tenants. The methods of agriculture were those which had been developed by the old inhabitants of the country. These had to be adopted by the free tenants who were engaging in the industry. The latter had to work side by side with the servile tenants. The open-field system rendered any separation of the laborers impossible. The Saxon conquerors had been unable to introduce any new system of agriculture, or even to control the system they found. They could compel the agriculturists to keep steadily at work in the fields, but they were unable to direct them in the employment of methods. Therefore, the latter had to be left in the hands of the servile population. In England, as elsewhere, the slaves who were found on the lord's inland could be retained only for certain personal duties, such as the care of the lord's stock and the performance of a few menial household services. The land of the demesne was cultivated by servile tenants. So, whether the freemen received holdings on the reserved portion of the estate or in the open fields, they had to work in common with the servile tenants and had to conform to the methods which already prevailed. While, at first, a distinction would be made in the character of the service to be rendered to the lord, that of the freemen being chiefly in the form of military service, the growing interest which the free tenant was bound to develop in his holding must, in the course of time, have rendered military duties more and more irksome, and have 
prepared the more settled clansman for the substitution of agricultural labor on the lord's demesne when the military duties were no longer needed. The economic condition of the free tenants and the serfs necessarily became the same, and the power of the lord over his tenants enabled him to hold them to the duties which were most profitable to him. With the demand for agricultural laborers constantly increasing, it was not to be expected that the lords would allow any of their men to leave the domains. Indeed, it could seldom happen that even a freeman would think of leaving the domain to which he was attached, any more than he would formerly have thought of detaching himself from the clan to which he belonged. The Teutonic freeman had never been mobile, and it was not likely that he would resist the tendencies that were leading to his permanent attachment to the manor which had taken the place of the clan. The ascendency of the military leader at the time of the invasions enabled him to exercise complete jurisdictional authority over the group of men who settled on his estate. This power, together with the conception of property rights which had come with the continuance of his position, gave him almost absolute authority over his followers; for the latter lost the feeling of approximate equality with their chief, had never possessed any conception of property for every individual, and were reduced by economic conditions to the powerless position occupied by the conquered population. Thus the manorial and feudal lordship was set over against the industrial community into which many elements had entered, but which had become a practically homogeneous whole. ${ }^{x}$

At all events, by the time of the Domesday survey the freemen had disappeared from the domains, except in the Danish districts where the lateness of the conquests and the precarious position of the lords had prevented the economic tendency from working out the perfect manorial system. These sochmanni or liberi homines of the Danish sections numbered about 35,000 in I086, and while occupying much the same position as the ordinary villeins, they were usually free from work on the lord's demesne,

I Cf. Andrews, op. cit., 8r. 
but were subject to military service. They could not sell their lands, nor leave without their lord's consent. Probably the Danish chiefs had seized the manors of eastern England, and had put their followers in the place of Saxon villeins who had been killed or driven off; but the new agriculturists were not willing to submit to such hard terms as had been exacted of their predecessors. ${ }^{\mathrm{I}}$ Possibly, also, some of the men enumerated under these heads in Domesday were men brought over by the Conqueror. These men were not numerous, but they received special protection from the king, and were kept from falling into the servile condition of the Saxon villeins. ${ }^{2}$ The important thing to notice is that the free tenants were superimposed upon the servile community and tended to become assimilated with the latter. The same phenomenon was undoubtedly found during the earlier Saxon period. It shows the tendency of the economic condition to determine the social status.

The description of the agricultural organization at the time of the Norman invasion may be made very brief; for on this point there is little difference of opinion, and many detailed descriptions have been given by writers of social history. The estate resembled the Roman villa in many respects. The lord possessed certain demesne lands, part of which were located directly about his residence and part scattered in strips amongst the strips of the tenants. These lands were cultivated by the holders of the strips, and the labor of the serfs on the lord's lands was the chief rental for their own holdings. Of these cultivators there were two main classes: the villani, of whom there were about 108,500 in 1086, whose holdings amounted to about thirty acres on the average, scattered in half-acre strips over the common fields, and who owed the lord two or three days' work a week, a certain number of extra days during the busiest seasons or when the lord might demand them, and small quarterly payments in kind or money; the bordarii, of whom there were about 88,000 in 1086 ,

× Ashley, An Introduction to English Economic History and Theory, I, I7-19; Seebohm, op. cit., 87-89.

2 Statutes of William in Annals of Roger de Hoveden (Riley ed.), I, 538, 539. 
whose holdings averaged five acres scattered like the holdings of the villeins proper, and who owed the lord one day's work each week and a few extra days at harvest time. Where the so-called free tenants were found, they possessed holdings and owed services corresponding in general to those of the villeins proper. On the demesne lands there were sometimes a few personal slaves whose duties have already been mentioned. Sometimes the holding of a villein was divided, presumably among his children, when each section owed its proportion of service to the lord. Occasionally, two such tenures might be united under one villein, probably by marriage. The bordars, including the cottars who were practically of the same class, were probably either younger sons of the regular villeins who belonged to the estate, or wanderers who had been induced to settle there. Their presence may be explained by the desire of the lord to secure as many laborers as possible. This was not always easily done. The lord was constantly having difficulty in finding enough laborers to cultivate the demesne profitably, and the bordars, not having enough land to support them, were very willing to hire out for wages in money or supplies.

The supervision of the work of the manor, the preservation of order, the care of products, the management of the mill and oven, and all similar work not directly agricultural, were performed by men drawn from the villein cultivators. Sometimes these officers and servants were compensated by being relieved of the duty of working the lord's land; sometimes they received a share of the profits connected with their duties. The ministerial class was always servile, even when freemen were found on the domain. These officers came to have special privileges, and sometimes claimed their offices as a hereditary right.

The method of cultivation on the strips of the villeins was doubtless one of joint labor, each laborer contributing oxen and time in proportion to his holdings. Probably only a few of the villeins of a given manor would co-operate on a given portion of the open fields. This division of the whole body into companies would be most convenient, since the distribution of the half-acre 
strips among the tenants usually followed a regular order and the holdings of certain groups of the villeins nearly always lay together. The three-course rotation of crops was almost invariably followed. The general features of the manor were those of the Roman villa, but personal slavery could not be maintained, and the cultivation on rental was always practiced. ${ }^{x}$

The first effect of the Norman Conquest was a legal degradation of the villeins. The feudal system was more highly developed among the Normans, and the more definite conception of villeinage held by them was naturally carried over to England. The slaves entirely disappeared and the sochmen fell to the position of the other tenants. The attitude of the Norman lords to the conquered population, especially since frequent rebellions served to keep up animosities, was not likely to improve the condition of the servile class, except as their more advanced feudal institutions might have such an effect. And yet the claim of Vinogradoff, ${ }^{2}$ that the freedom of the serfs was much greater in Saxon than in Norman times, is scarcely justified by the evidence he produces. The free village community had not existed in the beginning; the earlier Saxon serfdom was working itself out toward a higher form of tenure-an advance which was not checked by the throwing of the Saxon freemen themselves into serfdom; and this advance toward freedom was assisted by the conditions which prevailed after the conquest. The more settled government and the established order, with which the Saxons had never been familiar; the increase of commerce through the connection with Flanders and Normandy; and the tendency to create vast estates by the amalgamation of many smaller ones under a single lord, contributed to bring about a greater freedom, to the industrial classes than any new legal definitions could

I The oldest sketches that give a connected view of manorial life are found in the Rectitudines singularum personarum of the tenth century, but particular features are revealed in numerous remains of the earlier Saxon period. For a detailed account of the manorial organization and methods of agriculture, vide Seebohm, op. cit., 84-97, 129-42; Ashley, op. cit., I, chap. i; Andrews, op. cit., 97-145.

2 Op. cit., 132-36. 
counterbalance. The Conquest hastened the development of feudalism that was already going on in England; but the strong monarchy prevented many of the disruptive tendencies of feudalism that were found on the Continent. The Norman aristocracy, because of race antagonisms, was compelled to act as a class instead of a mere collection of individuals. ${ }^{x}$ William was able to carry on on a small scale what Charlemagne had attempted. Only the slowness of the development of manufactures prevented England from developing much more rapidly than any other country toward the ideal condition we have considered. The complete interdependence of men in society could not be brought about while they were engaged almost exclusively in agricultural pursuits. But manufactures could not be developed as quickly as they were on the Continent, because the old processes were entirely lost. Until artisans who could bring back some of the lost arts of the ancients could be secured, England's industrial development had to be very slow. But the agricultural organization was being perfected, and the basis was being laid for future industrial greatness.

The formation of the greater domains, or the union of several domains under one lord, made it less possible to maintain a close supervision over the villeins. The lords came to exercise a control that was chiefly political, the production of the required economic results being left wholly to the serfs. "The more powerful the manor became, the less possible was it to work out subjection on the lines of personal slavery."2 Personal slavery disappeared, and the serfs came to enjoy greater and greater freedom. Legal freedom was not possible, nor was it desired by the serfs. The lord was interested in the returns, and cared little about the social status of his serfs, provided they did not leave the domain. Stress was laid on the terms of the particular tenures, not on the status of the particular tenants; more on economical conditions than on legal distinctions. ${ }^{3}$ The interest of the lords

× Vinogradoff, op. cit., r79-8r.

2 Ibid., 132.

3 Ibid., 144 . 
was in the results, and the methods were left in the hands of the serfs. This tendency was marked even before the Conquest; the formation of greater estates simply accelerated the movement.

Another result of the Conquest was the momentum given to the tendency to commute labor rents and rents in kind for money rents. To a limited extent this practice had been carried on by the Saxons. Under the Normans it was extended. The greater number of domains under a single lord, often widely scattered by the policy of William, made money more convenient than produce; and the enlarged commercial relations created a greater general demand for money. The latter were still almost insignificant; but intercourse with Normandy made possible the exchange of English wool and a few other raw commodities for the manufactured products which were already being consumed by the Norman nobility. Money is needed only when commercial relations create an economic community too large to permit barter to continue. Again, the political organization helped the economic tendency; for the king demanded taxes in money, and inaugurated a fiscal policy which did much to undermine feudalism. ${ }^{\mathbf{1}}$ Later, the Crusades created a still greater demand for money, and the lords were glad to commute the dues of their serfs. Everybody found money more convenient than ploughings and agricultural products; and this change could the more readily be made because the number of bordars who had not enough land in tenure to occupy their whole time was now large enough to furnish an adequate supply of wage-laborers. The permanent gain, however, was on the side of the serfs; for they not only got rid of the burdensome obligations of personal service, but their class was greatly elevated later by the general rise of prices. The rents having once been fixed on the basis of the existing value of a day's labor, could not be increased, for custom continued to govern all the ordinary affairs of life.

These two tendencies, then, which were already found in Anglo-Saxon manorial life, were strengthened by the changes

I Ochenkowski, Englands wirthschaftliche Entwickelung am Ausgange des Mittelalters, II, 12. 
introduced by the Normans: the tendency to lose control of the industrial processes after the men had been organized on the domains, and the tendency to change from the system of natural husbandry to money rents. Directly, the Normans introduced nothing. The open-field system which had come down from the Roman period was left unchanged until the great inclosing movements began. From the time of the organization of the servile population that had been spared to labor for the Saxon conquerors, there had been no serious break in the movement toward personal freedom and the development of an individual who should find the values of the social process in his own activity. The swallowing of the Saxon freemen in the manorial system was only an incident in the development of an individuality such as they had never known in the days of their supposed freedom. A more vigorous element was infused into the industrial classes, but the industrial methods were unchanged. The personal freedom that was finally attained was an economic freedom, differing alike from the freedom of the older privileged classes who had always stood above the industrial classes and from the freedom of barbarians still living in tribal relations. Although the commercial development was needed to complete this movement, its essential principle was found in this freeing of the technique of labor. The commercial development was to free the product of labor as well.

The position of Vinogradoff, from which the above differs at many points, is largely to be explained by two misconceptions. The first of these is one held in common by many eminent advocates of the free-village theory, namely, the idea that the member of the tribal community is a freeman in any such sense as we use that term today. The member of a tribal community is not subject to a single master. He may even have a voice in the councils of his tribe and in the selection of his chief. None the less, he lacks that consciousness of individuality which constitutes the modern individual a freeman. He is ruled absolutely by tribal customs that are often more tyrannical than any individual lord could be, and he does not think of himself as having 
rights and privileges as against his community. The tribe probably never has perfect liberty to choose its chief, since that matter must be largely decided by lot or blood. ${ }^{x}$ If, therefore, it becomes necessary to make the tenure of a chief permanent or hereditary, the tribesman probably loses little of his liberty for a long time. The permanent chief gains in individuality and may gradually change the tribal customs to suit his own will, but the tribesman seldom loses by the change. Not until economic necessities forced the Saxons to agriculture could it be said that the position of the tribesmen was compromised; and then it was compromised chiefly because they had to take their stand beside a servile class. That servile class was composed of men who had formerly belonged to village communities of an industrial character, probably owning slaves who were employed on the common lands. This communal agriculture was changed and advanced toward the manorial type when the Romans came, but still retained its communal features. But neither on the British nor on the Saxon manors were the communal features inconsistent with a lordship such as was found in the feudal period. We may agree, with Vinogradoff, that "the communal organization of the peasantry is more ancient and more deeply laid than the manorial order;" 2 but it may be denied that this fact necessitated free tenures on the manorial domains or communities of free Saxons anywhere.

The second misconception of this writer is due to his use of facts belonging to the period when the villeins were entering into the enjoyment of larger liberties to prove that larger liberties had been enjoyed under the Saxon régime than under the Norman. This is a most serious historical fallacy. Starting with the assumption that the Norman Conquest meant the degradation of the serfs, he uses every document of Norman times to prove that the practices of those times were merely survivals of the earlier and freer Saxon times. The tendency toward greater freedom he interprets as a tendency away from greater freedom, as a survival of

× Maine, Village Communities, I55, ${ }_{5} 6$.

Op. cit., 408. 
still greater freedom that had prevailed in the earliest Saxon times. He says:

The Feudal period . . . . shows everywhere traces of a peasant class living and working in economically self-dependent communities under the loose authority of a lord, whose claims may proceed from political sources and affect the semblance of ownership, but do not give rise to the manorial connection between estate and village. ${ }^{3}$

This is true; but the communities were self-dependent simply because of the facts we have set forth; namely, that the lords could not control the processes of industry, while the conditions of the times would not admit of a commercial interdependence. The first task of the Saxon conquerors had been the settlement of themselves and their followers in small companies on the domains of the Britons and the reorganization of the peasants who were to supply the simple wants of the barbarians. This done, they had no further interest in agricultural processes which they but vaguely understood. The laws of Ethelred, taken in connection with the laws of Ine, carry back the Saxon manor to the sixth century; and since the greater part of the West Saxon conquests were not made until the latter part of the sixth century, "there is too short an interval left unaccounted for to allow of great economic changes-to admit of the degeneracy of an original free village community .... into a community of serfdom." 2 This organization was allowed to remain undisturbed during the next five centuries. Under its workings better returns could be secured than in any other way; and the lords being interested only in political control, so long as they received sufficient food supplies, left the control of the industrial processes in the hands of the laborers. This tendency to let the organization run itself became more marked after the Norman Conquest, because the domains became larger or more numerous and, therefore, less easily controlled, while the lords were even more entirely occupied with political affairs. The feudal system, once established, was chiefly a political system. In the beginning, the agricultural

I Op. cit., 408, 409 .

2 Seebohm, op. cit., I79. 
organization received attention only because the political system was conditioned by it. The lord and the "home-estate of the lord," as Vinogradoff truly says, were "tacked on to this settlement and dependent on the work supplied by it;"x but the lord was "tacked on," not to a free village community of which he was simply the elective chief, but to an agricultural organization that had come down from the past and which was essential to the welfare of the new society of which the lord was but one of the organs. These lords lost control of the industrial organization, as the Roman masters never did, and directed their attention to military and political matters; while the laborers, left to themselves, worked out an independence which no laborers had ever before enjoyed. The payment of the firma unius noctis to the king is not inconsistent with the servile condition of the villagers, in view of the nominal claim which the king had on all lands or of the fact that many domains were granted to nobles on various conditions by the king; nor is it incredible that such serfs should sometimes lease the manor and work it for their common benefit while the lord was away on a crusade; nor do we find evidence of freedom in the fact that the villagers came to have customary rights, which few lords could gainsay, to pasture their sheep and cattle on the uncultivated lands of the manor. All of these facts go to show that the servile village tended to become more and more self-dependent simply because the lord could only be "tacked on" to a system which he was unable to control in most of its workings. The barbarian lords could conquer the old populations and compel them to become the producers for the new society, but they never could control the technique of the producers. Until the beginning of the modern period, that could be controlled only by the workers themselves. Nevertheless, the political control was so largely conditioned by the economic organization, that the ruling classes were obliged to gain a semi-political, semi-economic control of the latter. Therefore the feudal system was a system of petty states, each of which was coextensive with the agricultural area that sustained it. The

O Op. cit., 404 . 
creation of larger economic communities meant the decay of feudalism.

Resuming our consideration of the internal economy of the manor, we find that, although a survival of tribal cultivation, it was undoubtedly very similar to the Roman colonate in its main aspects. The villeins greatly resembled the Roman colons. They held half-acre strips scattered all over the open fields, but following a regular order, which suggests that they had not always been held permanently, but were allotted each year according to the needs of the various households. ${ }^{x}$ The total holdings of the villein were almost always about the same, and descended in single succession. This shows that the permanent tenures were assigned after the workers had ceased to be free, since tribal practice would have led to divisions among children, thus rendering the holdings unequal within a few generations. The tenants of all classes lived in the village of the manor and formed a socially independent and self-sufficient group. These groups, especially after the stronger central government was established by the Normans, gradually became less and less self-sufficing; but until the rise of commerce, the interchange of commodities was inconsiderable, and the wants of the villeins were wholly supplied from within the manor, excepting that such commodities as iron and salt were not produced everywhere.

Within the manorial domain the lord had almost complete jurisdictional power; but after the Conquest he was limited in general matters by the public authority as few of the continental lords were. Since the public power did not interfere with the internal affairs of the manor, some provision had to be made for the preservation of order. On the Roman villas this had been attained by the arbitrary control vested in a representative of the master. But with the extension of the colonate, and especially after the development of mediæval serfdom, it became more convenient to permit the tenants to preserve order among themselves. Custom having such an important place in mediæval life, it was very easy to fall back on the judgment of all the men

× Seebohm, op. cit., Ir3, Ir9-25; cf. Vinogradoff, op. cit., 234 ff. 
of the village meeting under the presidency of the lord's steward. Only in later times did a distinction arise between the court baron for the free tenants and the customary court for the servile tenants, and there is every reason to believe that the former was a Norman institution $^{x}$ introduced for the benefit of the more privileged Norman soldiery. The manorial courts showed the same tendency that we have found in other manorial institutions. The interest of the lord being only in the results of manorial production, the villeins were left to work out such a system of law and order as would best serve their own interests, provided always that the domanial authority of the lord was not encroached upon. With the freeing of labor by the process we have described and the commutation of the service for money rent, it was most natural that the oversight of the lord should be more and more relaxed. Later, the public law provided for the local administration of justice whenever the lord and his steward became negligent. ${ }^{2}$

The system of agriculture found in England by the Saxons was maintained until the fourteenth or fifteenth century; and the semi-political control of the villagers by the manorial lords continued to be the only real government until the economic community became larger than the manor and required a new system to meet new needs. The productivity of the agricultural organization was comparatively small-only about four to six bushels of wheat per acre ${ }^{3}$-and the entire population had to devote its

x Cf. Vinogradoff, op. cit., 354-96. This is one of the ablest discussions of the subject, though the author shows his usual tendency to use evidence of freedom found in the constitution of the courts to prove that a greater freedom had existed in the past, rather than as evidence that a greater freedom was developing.

2 "The courts of the manors, and the parish meetings of a later date, had certain features which, if we start with an unconscious presupposition as to the original constitution of Anglo-Saxon society, may easily strike us as archaic, as vestiges and survivals. But this is one of the most dangerous arguments. Every one of these customs and features may be just as well-in default of evidence to the contrary-regarded as the outcome of an evolution away from the original condition."-Ashley, "The Anglo-Saxon Township," Quarterly Journal of Economics, VIII, $36 \mathrm{r}$.

3 Rogers, Six Centuries of Work and Wages, rig. 
energies to the cultivation of the soil. Yet the system supplied the needs of the sparse population and gradually came to furnish a slight surplus. The surplus-especially of wool-served as the basis of wider economic relations which finally broke down the manorial system and produced a wider and more complex social organization. The barbarians had been obliged to start with the agricultural system found by them in Britain, and in time an organization was perfected almost identical with that which the same political and economic forces were developing elsewhere. Until this system could produce a surplus, the aspirations of Europe for social organization could not be realized. The state had been practically coextensive with the agricultural community. The insular position of England and the character of the Norman rule enabled the various sections to come together a little earlier than was possible with similar sections of continental countries. In a measure, the ideal element as represented by the king and the Church was able to hasten the integration; but this was not fully accomplished until the fifteenth century, when the economic conditions made possible a wider society no longer subject to feudal limitations. Except during periods when military necessities brought the whole country under the control of a single resolute leader, England never had a real king until Henry VII, although the central authority was more than the shadow that it was on the Continent.

Western and central Europe.-Turning now to the more important movements of the Continent, we find that, while the provinces were conquered with comparative ease, there were still forces which caused the invaders to maintain, for a time at least, a central organization such as was not found in Italy and such as was not found in England until long after the Conquest. Leaving Spain out of consideration, since the movements there were of minor importance for Europe, and disregarding the Scandinavian countries, whose development was too tardy to be of interest to us, we find in Gaul and those Germanic regions which were brought under the dominion of Charlemagne the movements which were most characteristic in the reorganization of Europe. Many of the de- 
tails of the organization of the feudal domain need not be considered here, since they were practically identical with those described as belonging in more typical form to England and Italy; but it was in these regions that the essential reconstruction of society went on. The movement in England was too tardy and too much under continental influences, while that in Italy was too immature and too largely conditioned by the survivals of Græco-Roman cities, to be properly regarded as typical of the general course of events. It was in the Frankish empire that the aspirations after social integration were most marked, and it was there that the inability to carry forward the political in advance of the economic organization was most clearly shown. The development of the interior of Germany was not so typical of the real movement because it was delayed until the influence of the Frankish development became pronounced.

The development of feudalism in the Frankish empire continued from the time of the invasions to the death of Charles le Gros, when the system was practically complete. The Franks had been among the most backward of all the Teutonic races. When the Völkerwanderung began, they were still heathen, were only half clad, and had little political unity. Shortly before the invasion, they were still divided into numerous petty tribes, each under a hereditary ruler. About the time of the fall of Rome, these tribes had come together in a pretty compact nation, for they had begun their movement across the Rhine. By 48I the Salians had taken the towns of Cambrai, Arras, and Tournay, and the Ripurarians held Cologne, Treves, Mainz, and Metz. The father of Clovis, who died in $48 \mathrm{I}$, was the most important chieftain, and ruled the valley of the upper Scheldt from Tournay. Clovis easily took the entire Seine valley, and gradually killed all the other Frankish chiefs, leaving himself the sole Meroving. From being the permanent war-chief, he easily extended his authority over all things. The country was so easily conquered that he spread his men over a wide area. No folk-moot could any longer be held to regulate the affairs of so wide an empire; therefore the leader took counsel only of such impor- 
tant men as he chose to summon to him. He became almost immediately an absolute monarch.

But the conquest raised difficulties for the new monarch. The band of invaders was relatively so insignificant that it was necessary to allow the conquered provincials to manage their affairs pretty much as they had done before; and Clovis was shrewd enough to make extensive use of the Christian bishops in administering his empire. When spread over the whole country, the Franks had to remain small bands of rulers and soldiers. Fustel probably underestimates the numerical stength of the invading force; but it is undoubtedly true that it was inconsiderable as compared with the conquered population. Else, how can we account for the persistence of the Gallo-Roman speech and the ready acceptance by Clovis of the Gallo-Roman religion? The old provincials had become the most thoroughly Romanized of any class in the Empire, and the very large element of Teutons that had been settled in the province had become both Roman and Christian. These had become too completely absorbed by the Gallo-Romans to be of any immediate assistance to Clovis, or to modify radically the provincial institutions. The military organization perfected by Clovis prevented any such immediate disintegration of the Franks as the Lombards and Saxons had experienced; but when settled over a large area and relieved from the danger of invasions, the administration of so vast a nation became a serious problem, and one for the solution of which Clovis and his successors needed all the help they could secure from the natives.

This assistance was assured when Clovis embraced the orthodox faith. The influence of Chlotilde and the unconscious influence of the majestic ritual which he found in his new dominions may have had something to do with the conversion of Clovis; but from what we know of his character and methods, it is safe to conclude that his chief motive was the desire to secure the support of his new subjects. The latter, especially the clergy, served him with a loyalty which no Gothic, Vandal, or Burgundian leader could ever win; and much of his success in his opera- 
tions against the Visigoths and in his efforts to establish his kingdom on a permanent basis may be attributed to this cause. In a single generation the Franks all became Christians. ${ }^{x}$

The assistance which Clovis most needed was in the way of administrative machinery for the control of his vast kingdom. As we have seen, he became an absolute monarch; but had it not been for the assistance of the clergy and administrative agents of the conquered province, he would have been helpless in controlling his new dominions, except as he could be present in a given section with his military forces. No barbarian ruler was able to frame a system by which he could hold various sections together, except as he was able to march quickly from one to another. Nor could his Frankish chieftains attend to any but military duties. They were too ignorant to serve as clerks and too rude to comprehend the real needs of the districts they controlled. It was because of the violence and ignorance of the barbarian lords that the system established by Clovis finally broke down; but the maintenance of it for a while was of importance in holding society together during the times of greatest disintegration.

One chief cause of the failure of the Merovingian system was the practice, growing out of the conception of the absolute power of the king, of dividing the country among the sons of the king, according to the Teutonic ideas of inheritance. This fact also indicates that land had not long been a matter of private property, for the results of frequent subdivisions of land would be so disastrous that the practice could not be kept up permanently. These divisions of the kingdom caused so many internescine struggles and so many minorities that the power of the kings was soon greatly weakened. But at no time, even under the rois faineauts, were the kings less than absolute monarchs; nor at any time did the people think of the various divisions of the empire as separate nations.

Clovis, like the other barbarian conquerors, felt an admiration for the institutions he was attacking. The high respect paid to

I Oman, op. cit., $5^{8-64}$. 
the supreme power by the provincials exactly suited him, when it was transferred from the emperor to himself. The powers vested in the ruler by the Roman law won from him an approval of that system which nothing produced by the barbarians could elicit. The bestowal upon him by the eastern emperor of the title of consul seemed to him and to his subjects to ratify his conquests and to clothe him with the majesty which had belonged to the emperors. ${ }^{x}$ Added to these advantages seen by Clovis, he had the same reason for making use of what he found that was present with all barbarian conquerors; namely, that, coming as colonists and not merely as conquerors, the better mode of life made possible by the inventions and devices of a civilized people could be enjoyed only as those inventions and devices and the men to work them were preserved.

During the whole Merovingian period, the system accepted and modified by Clovis was maintained, though it finally became but a shadow. The governmental machinery was a composite of the Teutonic and Roman systems. The royal household perpetuated some of the features of the comitatus. The personal companions of the king were his antrustions, the chief of whom was the Mayor of the Palace. At first, all of these, except the referandarius or secretary, were Franks; but by 605 the office of Mayor of the Palace was filled by a Gallo-Roman. The government of the provinces was intrusted to counts and dukes who were named by the king and could be removed at his pleasure. In the purely Teutonic sections of the empire the unit of administration was the old tribal district or gau; in the Gallo-Roman section it was the civitas with its surrounding district. On the borders several countships were sometimes united under a duke. These provincial governors appointed vicarii and minor officials. The administrative system was thus copied after that which had existed under the Empire. ${ }^{2}$

A great source of strength to the king was his acquisition of

× Bryce, op. cit., 30; Oman, op. cit., I21, 122.

2 Oman, op. cit., 125, 126; Fustel de Coulanges, Les origines du système féodal, 347-53. 
the vast imperial domains. These now became the private property of the family of Clovis. These estates were administered by the king's domestici. The income from these domains, together with the revenues exacted from the various districts by the counts and customs duties levied at frontiers, gave the king great nominal resources. But abuses soon crept in which the Frankish kings were less able to handle than the Roman emperors had been; and the revenues actually received were insufficient to maintain a strong government. Because of wars among the rival successors of Clovis, the kings were obliged to purchase the support of powerful nobles by granting large estates from the royal domains. Other domains were appropriated by officials who were charged with their care, and kings were frequently too weak to dispossess the robbers. Finally, the royal counts became local despots, or else were unable to control the nobles of their districts. Out of these administrative weaknesses, together with the development of the manorial system, grew feudalism in its strongest form.

The domanial organization did not differ materially from that of England. We can not be sure that the open-field system was found everywhere on the Continent. No such detailed studies of the continental methods of cultivation have been made as we have for England. At the time of the conquest, the Roman villa and the German heim were becoming more and more alike. Slaves were becoming scarcer in Gaul because the wars of conquest had ceased; and the labor of colons and freedmen was being substituted, as already described. The invaders appropriated both the lands and the occupants. It does not appear that all of the provincial proprietors were dispossessed, but the greatest estates must have passed into the hands of the Frankish leaders, while the imperial domains became the property of the king. The Church lands, at least, were not disturbed by the conquest. They were probably increased. The changes in ownership which took place did not change the methods employed. At the time of Charlemagne, the nature of the domain was not materially changed, except that men who had been in 
personal servitude had become villein tenants. The domains became the absolute possession of the lords, as had been the case under Roman rule. The organization was usually such that it was practically impossible to divide a domain that had once been established; but the possession of groups of domains made it easier for the lords to avoid leaving a single domain to several sons in common. There is no evidence whatever of communal ownership by a group of Frankish freemen. The tribesmen, as in the other cases considered, were taken on the domain by their chief, and remained, for a time at least, freemen and soldiers. Such freemen, franci, were found on the royal domains in the time of Charlemagne, ${ }^{\mathbf{x}}$ and had doubtless existed on all estates under the earlier Merovings. These men must have constituted a non-industrial, military class. That this was the case is shown by the fact that the proprietors, at a much later date than the first settlement, would frequently bestow upon these freemen lots within their domain, in recognition of their faithful service. These lots might be given jure proprietario or sub redditus terrae. In the latter case the beneficiary evidently became a tenant; in the former he held the land free of charges, ${ }^{2}$ but since his lot could not be cut out of the domain, he must have worked under the conditions that governed the serfs, though he probably rendered military service in lieu of labor, as with the sochmen of England. Rents and duties doubtless seemed to the tenants the legitimate price of the land they enjoyed, and were not regarded as marks of servitude. Nevertheless, the tenure inevitably threw the man into dependence upon a great proprietor. The man might be personally free, and yet be subject to the proprietor on account of the land he occupied, and this subordination always tended to become hereditary. Thus the freeman came to occupy practically the same position as the serf. If the freeman should undertake to cultivate a lot under contract, the outcome was the same. As conditions became more unsettled, it became increasingly more difficult for anyone except a great proprietor to main-

× Capitulary de villis, iv.

2 Marculfe, II, 36, cited by Coulanges. 
tain his free position. This class of free tenants on the way to villeinage was augmented by such artisans as remained after the decay of all industry and the destruction of the towns. Though the public power might protect these free tenants for a time, it was soon too weak to enter the domains to administer law or protect contracts. ${ }^{x}$

The invasions did not materially alter the colonate. Neither the Germanic nor the Christian spirit reproved the institution. The barbarian codes contrast the colons with slaves, but hold them to be none the less dependent. Legally attached to the soil, the colon was indirectly attached to the proprietor of the soil. If he left the domain, he could be returned by force. On the other hand, there are several records of judgments passed on masters for trying to evict colons. ${ }^{2}$ Such cases must have occurred before the decay of the royal power; and they could never have been numerous, for the proprietors were usually anxious to secure cultivators. The rents of colons were doubtless determined in the beginning by each proprietor for each colon, and consented to by the colon; but when once fixed, rents could not be changed. There is no evidence that the Franks tried to interfere with the customary rents of colons found on the conquered domains. ${ }^{3}$

After the conquest, the slaves bore the same names they had under the Romans-servi, mancipia. They were of every race; and a Roman proprietor might own German slaves. No distinction is made between the two classes in the charters or laws. The Germans had no thought of abolishing slavery; but enfranchisement went on, as under the Romans. The freedmen and the slaves alike remained on the land of the master. The tendency to employ slaves in the same manner as the colons, which we found on the Roman domains, was greatly accelerated when the land passed into the hands of proprietors who did not know how to work gangs of slaves. The slaves were given tenures

r Coulanges, L'alleu, 415, 416.

I Ibid., 358-60.

3 Ibid., 406, 407 . 
similar to those of the colons and on practically the same terms. It soon became impossible to distinguish between the two classes except by name; and we can hardly believe that the remembrance of their ancient liberty was highly esteemed by the colons. Intermarriages between the two classes began to take place; their habits and conditions of life were alike; the colon showed no repugnance at living in a servile manse; and finally the two classes were so completely confounded as to be designated by the single term, villani. ${ }^{\mathrm{x}}$

In this same class were included also the freemen who were found on the domain. It was inevitable that all of these classes should become amalgamated in one, for they all lived and worked under the same conditions and were subject to the same master It was also inevitable that the lordship of the master should come to be of the same semi-political, semi-economic character that we found prevailing in England. The laborers were left free to pursue their own methods, provided they supplied the wants of the master. The villeins could cultivate their tenures as they pleased. The industrial obligations of the tenants did not differ materially from those of the English villeins. One duty which does not seem to have been imposed in England appears-the hostilium, a moderate annual return to the lord for the support of his military establishment. Then, if war came, the lord bore all the charges, paying the amount due from his whole domain when he recognized the authority of the king. After the practice of working the demesne lands by gangs of slaves was abandoned, it is not certain that the open-field system was introduced on the old Roman villas. That system being the result of the modification of tribal cultivation by the checking of migrations, there is no reason why the invaders of Gaul and Italy should compel the agricultural population to substitute it for the system that was being introduced so extensively on the Roman villas. That the villeins held definite tenures can not be disputed; but whether the tenures were in scattered strips, necessitating common cultivation, or were in independent lots which

IOp. cit., 274-78, 413, 414. 
could be cultivated by the holder alone, with, perhaps, a little assistance at certain seasons, is not altogether clear. Fustel de Coulanges holds to the latter view, and it seems to be the more probable one; ${ }^{\mathrm{I}}$ but it must be confessed that he made no such thorough-going examination as Seebohm has of the English conditions. In the German regions of the Frankish empire the threecourse open-field system prevailed as in England. ${ }^{2}$ But however the land may have been divided among the tenants, the essential features of the manor were always the same. Whether starting from the Roman villa or from the German tribal community, the conditions always became practically the same. Everywhere the lands were held by lords and cultivated by tenants who, whether originally slaves or freemen, became a common villein class. Everywhere these villeins came to adopt their own methods in the cultivation of their holdings, returning to the lord only the customary rents and services. Everywhere the domains became complete economic communities, producing practically everything required for their simple life. And everywhere the political society tended to shrink to the dimensions of the economic.

The breaking of the Frankish empire into fragments corresponding to the economic communities was caused, on the one hand, by this development of economic independence, whereby a given community could supply all of its own wants and could neither help another community nor be helped by it; and, on the other, by the lack of ability on the part of the barbarians to maintain a permanent organization for peaceful life, so that when the invasions were over and no single foe threatened the nation, the empire fell wholly apart.

This economic independence of minute communities was brought about by several causes, most of which have usually been overlooked. First, we may note the violence which rendered commercial intercourse impossible. So long as the Franks

I L'alleu, 360-74. Most of the argument is based upon Guerard's Polyptyque de Saint Germain. Cf. Seebohm, "French Peasant Proprietorship under the Open-Field System of Husbandry," The Economic Journal, I (189r), $59 \mathrm{ff}$.

2 Seebohm, op. cit., 336-99. 
were held together as an army under Clovis, a considerable degree of commercial activity was kept up; for it was not the desire of the conquerors to interfere with commerce. When Gregory of Tours wrote his history, Gaul was still in relations with the East and the Mediterranean ports had not yet lost their importance. ${ }^{x}$ The direct cause of the destruction of maritime commerce was the piracy of the Saracens and, later, of the Northmen. But the main cause of the interruption of the commercial routes by land was the inability of the barbarians to organize a government. The empire fell apart as soon as the conquests had been completed; and only during the short period when the common danger from the Saracen invasion forced the various sections of Christendom to organize under the Mayors of the Palace and Charlemagne, could a government be maintained that was able to preserve order. Not from a desire to destroy commerce, but from inability to maintain orderly government, did the barbarians suffer the destruction of means of communication and make their local communities self-sufficient. Under the Merovings commerce did not become entirely extinct. This was because communication with the East was not entirely cut off, because the Roman roads, though neglected, had not become impassable, and because a certain amount of stored-up wealth and a few of the old industries still remained to serve as a basis for exchange. After the death of Charlemagne, the simultaneous inroads on all sides by Saracen and Norse pirates, which a strong government with great economic resources might have withstood, completely destroyed all possibility of commercial intercourse. The community that could not maintain itself perished. Each domanial community was shut in by itself. The residences of the lords and bishops became forts. No help could be expected from outside sources. Famines and epidemics became common. Money ceased to circulate. All that could be hoped for was a sufficiency of the simplest necessaries of life. ${ }^{2}$

I Pirenne, "L'origine des constitutions urbaines au moyen âge," II, Revue historique, LVII, 57. For convenience future references to this series of articles will be made simply by volume and page of the Revue.

2 Pigeonneau, Histoire du commerce de la France, I, 57-59, 87-90; Levas- 
A second important cause of the isolation of the domains was the lowering of the standard of living brought about by the invasions. The barbarians themselves desired little more than the necessaries of life. War had previously supplied their needs, and while they were now willing to take advantage of the opportunity to secure a more adequate and constant supply, their desire for much that had constituted the bulk of commerce was not strong enough to induce them to encourage manufactures in any way. Since they were the only possible consumers of the important products, and since they cared for little but food, ordinary clothing, and military equipment, such artisans as were left in the decaying cities had little incentive to keep up their industries. The destruction of the industries, or the falling-off of the demand for their products, withdrew the latter from circulation, and, consequently, left little occasion for the circulation of agricultural products. There was seldom, it is true, a surplus of these for exchange; but the fact that there was almost nothing for which the agriculturists cared to exchange their products meant that there was little stimulus to greater production.

This lack of any surplus of agricultural products for exchange constituted a third cause of the isolation of the domain. The disorganization of the domains, even where the appropriation was most peaceable, must have been very great. Before the settlements were completed much raiding took place, causing the destruction of property and laborers. The changes which cut off importations of food products made it necessary to raise crops for which given domains were not best suited, as when land that was admirably adapted to wheat had to produce grapes. This decreased the productivity of many domains; and, in turn, as more diversified but smaller crops were secured, still less was left for possible exchange. In Germany, where the domains were just being formed, the demands of settled life were with difficulty being met by the agricultural organization. There the system was modeled after that found in Gaul, but

seur, Histoire des classes ouvrières en France, I, 107, 108, 147-57; Inama-Sternegg, Deutsche Wirtschaftsgeschichte, I, 460-66; Oman, op. cit., 5I2-14. 
there was never a group of provincial cultivators to give impetus to the work. In places where cultivation was kept up without interruption, the interference by the newcomers and their inability to keep the workers up to their best caused a serious decrease in the productivity of the domains. Although the Romans were doing away with slave labor on the demesne, the barbarians, with almost no ability to direct such labor, allowed the old system to continue for a long time. Further, the constant wars carried on by the unruly lords against one another resulted in the destruction of many a crop and the discouragement of the cultivators. All in all, partly as the result of bad management of the system, partly because of local disturbances, partly on account of the cessation of commercial operations-which the scant agricultural products in turn made more complete-the food question soon became all-important to barbarian society; and the feudal system finds its chief explanation in the fact that every locality had to develop its own food supply. Until a surplus of agricultural products could be assured there was no possibility of a revival of commerce and the re-establishment of an economic interdependence that would bind distant localities together in one community. Within the domain everything was done with reference to securing the cultivation of as much land as possible. Since conditions were everywhere the same, the agricultural system adopted was everywhere the same. Not only was the type of domain everywhere the same, but this was the type of society everywhere. Whether or not a few communities of free villagers existed here and there throughout the civilized world, is a matter of very little concern to the student of European development. Such communities had undoubtedly existed in some places; but if any of them remained after the conquests were made, it was only in some out-of-the-way places and in sections which really lay outside of the essential movement of the times. Europe was everywhere organized on the manorial plan, and had to maintain that organization in order to exist at all and prepare for the larger organization that was to come. 
A fourth cause of disintegration was the lack of political ability among the Teutons. As stated, Clovis attempted to organize his dominions on the model of the Roman Empire, and called to his assistance the Roman bishops and many of the inferior provincial officers. With their help he organized an absolute monarchy. The tribes just emerging from barbarism had but poorly developed political faculties. This was true of both Saracens and Teutons. The former had a fanatical zeal that could carry all before them in Spain, but as, soon as the country was subdued interminable conflicts arose within their state. So, it was only under special pressure from without, or when under a resolute leader they attacked a more concentrated society, that the Teutons could be held together. The Merovingian monarchy soon began to crumble in spite of the aspirations of its chiefs. There was no organic social life expressing itself in the government. The latter was simply a mechanical system impressed upon the tribes from above. No hand could be strong enough to crowd the new life into the old form, except for brief periods when conditions were as described. Civil war raged among all the barbarian peoples, and kept back the industrial development which alone could form the basis of a strong and stable political organization.

It may be thought that the influence of the Roman bishops and administrative officers could have given strength to the Frankish monarchy. It did for a while; and without them it is not likely that either Clovis or Charlemagne could have organized a monarchy; much less could their weak successors have maintained even a shadow of one. But after the first generation or so, these bishops had themselves become Teutonic in their blood and life; and though the traditions of the Church and its method of selecting its leaders kept them somewhat above the average of the lay officials, yet during the darkest period the leaders of the Church showed little practical administrative ability. The ecclesiastical organization itself became very weak and might have gone to pieces, had it presented as many practical problems as the general social life raised. It was by holding up a general 
ideal of social organization and by realizing it on a small scale in religious communities that the Church most assisted the State. In a practical way the best that the Church could do was to modify slightly the civil strife. Not all the power of the Church over the barbarian mind could enable it to keep the mechanical frame of government in successful operation. The ideal of unity had a powerful influence, but its mode of application had to be determined by the social life. What the aspiring monarchs could not do, the petty lords and their servile tenants were accomplishing. Within each petty society law and order prevailed. Each secured the economic resources which became the basis both of a military organization that could protect Europe in the time of darkness and of the larger social integration that was to follow. When the lords had finally thrown off the restraints of the mechanical monarchy, they were able to withstand with their fortified castles and a few mailed horsemen the marauders whom the imperial armies could never touch.

The disintegration of the pseudo-empire went on from the time of the final settlement until the feudal system was fully formed. Not even the genius of Charlemagne could effectually check the movement. The phase of the disintegration which most clearly indicates the tendency to make the political community identical with the agricultural was the failure of the county system and the introduction of immunities. As we have seen, the Frankish king appointed counts to act as provincial governors. These functionaries were simply the representatives of an absolute monarch. They held courts and executed the public laws. Each countship was assessed a definite annual tribute which the count had to raise on his own responsibility. Since there was practically no restriction placed upon him in the collection of this tribute, he usually exacted a liberal commission. In holding court the count was likewise practically unrestrained. He sat in company with the rachimburgi, a few assessors chosen from among the chief men of his district. Though frequently the most powerful nobles of the county, these assessors had no legal authority apart from the count, but by ancient custom they 
were called in to assist him. The count had full authority except where persons were so great that they could be tried before the king. The assemblies met simply to hear decisions. The tribal customs had given way to an autocracy as complete as that of the Empire. ${ }^{x}$ In Roman times the provincial governor had been the real representative of the State. He was checked by numerous intermediate officials, and his authority was limited to civil affairs. The provincials readily looked to him for the redress of grievances and the development of local resources. The Frankish count gained greatly by the changed conditions of his times. The intermediate officials had disappeared, so that there was no one between him and the king who, of course, could not directly control all of his subordinates. He acquired military as well as civil powers. He probably no longer received a salary from the State, but had to make up his income from the district. When the king had ceased to control his counties by his own military power, the local count became a petty despot, and landowners found it desirable to obtain immunity from his jurisdiction. ${ }^{2}$

It was when the king was losing control of his counts and when the latter were becoming practically independent, just before the power of the monarch was completely lost, that the granting of immunities both hastened the disintegration and indicated a tendency that was inevitable in any event. The immunity always asserted the absolute authority of the monarch. It emanated from the free will of the king on solicitation of the beneficiary. It took the form of an ordinance addressed to the agents of administration, and implied the absolute power of the king to control them as mere agents. The concession was always accorded to individual lords, never to groups or districts. It was never treated as a right of the person immuned, but was wholly a royal favor, and had to be renewed for each generation to remain technically valid. ${ }^{3}$ By these instruments the public

× Oman, op. cit., 125, 126.

2 Jenks, "The County," Contemporary Review, LXXII (1897), 402-4.

3 Coulanges, Système féodal, 360-66. 
functionaries, that is, the counts and their agents, were forbidden to go upon the domain of the beneficiary to hold court or serve processes. $^{x}$ But while the jurisdiction of the royal agent was suppressed, the direct jurisdiction of the king remained in full force. In the writings of Gregory of Tours the nobles are represented as judged by the king. The beneficiaries of the immunities conceived of themselves as directly governed by the king. To the landowners the administrative agents appeared as masters, always present and always detested, who abused their power as judges and receivers of taxes. The king was more distant and had not the power to accomplish so much evil. The kings doubtless thought that the immunity fortified their authority by rendering it more direct and personal; but in reality they were powerless to assert their authority. If they could not control their counts, they were far less able to control innumerable individuals. Only a well-arranged administrative system could protect the interests of the central government; and so, when the counts were forbidden to act as royal agents on certain domains, the public laws could no longer be executed nor the taxes collected within the immunity. The absolute monarchy was preserved in theory, but in reality the immunity amounted to an abandonment of public authority, and carried disorder into the whole financial and administrative system that had been carried over from the Roman empire. ${ }^{2}$

It may be questioned whether the immunity was of any such importance as Coulanges claims, whether it was anything more than a mere surface indication of the unavoidable tendency of the time. If the king could not compel his counts to observe the laws which he himself desired to have executed, how could he give force to the immunities which he granted to favored landowners? If the counts had become local potentates, why should they relinquish their authority on the mere command of an impotent king? The answer is, that it was only before the king had lost all coercive power, and before the lords of domains

× Coulanges, Système, 372-75; L'alleu, 454-56.

2 Coulanges, Système, 397-99, 407, 412. 
had quite attained to independent power, when the counts were actually administering the public law, but were practicing many abuses, that the immunity could have any force as emanating from the king or could be needed for the protection of the lords. The counts had become more powerful in their districts and had slipped beyond the control of the king, but a part of their power consisted in the recognition of their relation to the royal authority.

It is noteworthy that nearly all of the known charters of immunity were granted to bishops and abbots, though lay charters are not unknown. The greater number of grants to ecclesiastical lords may be only apparent, for the documents were much more likely to be preserved by them than by the laics; but it is not at all improbable that more immunities were actually granted to them than to laymen. The Frankish kings were notoriously partial to the Church, and would be likely to relieve the ecclesiastical domains from external interference whenever complaint was made. They would likewise be more willing to have the ecclesiastical lords administer the laws on their own domains, and more disposed to allow them to escape taxation. And the ecclesiastical lords were more likely to ask for immunity, because less able to resist by force the extortion of the count. The immuned lords were supposed to administer the public law on their domains and to continue to pay taxes; but there was no one to see that the law was observed, and it was easy to stop paying taxes when there was no local collector. It was especially easy to divert public taxes for religious purposes. The ordinances commanding the counts to keep off of the ecclesiastical domains would be more likely to be obeyed than those exempting lay nobles from their jurisdiction. It is true that the hostility between a count and a bishop was sometimes very great, especially when both occupied the same city; but the same superstitious regard that the kings showed for the clergy was held by the counts also, and was likely to prevent them from violating the undoubted privileges of bishops and abbots. When engaged in an actual struggle over immediate questions of authority, the counts, like the later emperors, were likely to lose their reverence; but when 
an actual struggle was not going on, religious awe was felt by the most reckless of them, and an immunity recognized in sober moments would be taken as a matter of course later on. The lay nobles enjoyed none of these advantages with either authority. Only in the case of special favorites or in return for special services would the kings care to grant them immunities; and when they were granted, if the royal power could not control the counts, the immunity meant only the legalization of an independence which the lord of the domain was able to maintain against the count by his own unaided efforts.

It is not to be supposed that the immunity had no influence in developing the feudal system. In an age when so much importance was attached to custom, the mere shadow of royal authority would for a long time restrain the counts, even when the latter had become the most powerful seigneurs in their districts; and it is undoubtedly true that immunities were frequently respected by counts whom the king could not prevent from acting as local tyrants. In so far as this was the case, the action of the kings strengthened the growing power of the domanial lords at the expense of the counts, and hastened the development that was going on anyhow. It also hastened the disintegration of the monarchy; for the nominal support received by the kings from the counts was weakened, and the last vestiges of the administrative system were destroyed. But it only helped on these movements; it neither started nor consummated them. The domains had become the real political units, and the traditions received from the Romans could not permanently hold them together in a larger political society.

The counts finally came to be simply powerful domanial lords like their neighbors, having practically no real authority save that which their resources gave them. If they were more powerful than others, it was simply because they had larger and better organized estates. By reason of their possession of a large share of the old imperial domain which they had been able to hold successfully against their weak masters, they were usually among the most powerful seigneurs, but they received no support from 
the central authority. The king himself became a simple seigneur, and had little more real authority than the possession of his domains gave him. The efforts of Charlemagne to reorganize the countships proved ineffectual. He intended that the counts should thereafter be checked by a set of royal officials who should visit the various districts at frequent intervals. But the possession of the power with which the king had to clothe the counts in order to enable them to discharge their duties, a power derived from their control of vast domains, soon enabled them to make their office hereditary. As shown in the discussion of the Italian countships, the only men who could maintain their authority were the men who controlled the largest local estates; and these men could exercise that authority independent of the king's support. The latter could never collect an army to dispossess them. If he had succeeded in removing any of them, the men installed in their places would immediately have become as independent as their predecessors had been.

The scheme for supervising and checking the counts did not work, for the king could command neither the administrative ability nor the resources that would enable him to touch all parts of his dominions at the same time, as the Roman emperors had done. The Carolingian counts started off with less jurisdictional authority than those of the Merovingian period had possessed; for Charles recognized the principle of immunity as general, and did not expect his agents to interfere with the internal affairs of the domains. ${ }^{x}$ The feudal principle was so far recognized that it was impossible for the Carolingians to check its further development. The family wars of the descendants of Charles obliged them to seek the aid of their semi-independent subjects, and further concessions had to be made until the royal authority was wrecked. The accession of Otho to the imperial crown in 962 marked a recognition of the feudal principle in its entirety. The dissolution of the artificial social bond which had held Europe together since the conquests of Clovis facilitated the formation, in the interior of Christendom, of a vast number of

- Capitulary of 8ro, xvii; of 813, xi. 
small groups of domains left free to work out their own problems. ${ }^{x}$ "No one thought of common defense or wide organization: the strong built castles, the weak became their bondsmen or took refuge under the cowl: the governor-count, abbot, or bishoptightened his grasp, turned a delegated into an independent, a personal into a territorial, authority, and hardly owned a distant and feeble suzerain.",

Feudalism, however, was not entirely lacking in substitutes for the wrecked administrative system. It furnished an arrangement by which society was held together in a nominal way and kept from falling altogether into political anarchy. The system of benefice and patronage preserved some measure of solidarity, and in times of special need enabled the people to come together with some organized force. The two institutions of benefice and patronage were correlative. The man who passed under the control of another passed under patronage; he became a vassal of that other. He did this by commending himself to the more powerful man whose protection he sought. In surrendering himself to another he surrendered his domains as well. $\mathrm{He}$ received his lands back again, and managed them as before; but they were now subject to certain services and duties. Personal liberty and allodial property were alike surrendered in such cases; but in most of the ordinary affairs of life no change could be observed in the activities of the vassal or the conduct of his domains. He had simply pledged himself and his resources to another, when his assistance might be required by that superior, and had received assurance of protection from a more powerful noble. "Men submitted themselves to one another by a series of recommendations. By a series of acts of benefice the lands likewise came to be placed in a hierarchy one to another."3

The cause of this system has already been mentioned in the discussion of Italian feudalism. It grew out of the needs of industrial and military life. The lord who possessed a very small

r Sismondi, op. cit., I, 81, 82.

2 Bryce, op. cit., 79.

3 Coulanges, Système, 336 . 
domain would be unable to defend himself against aggressive neighbors. He would conclude that it would be better to hold his lands subject to the duties of vassalage than to have them wrested from him altogether. On the other hand, the powerful noble who held many very large or scattered domains would find it impossible to control all of them. He would rather grant some of them to a weak neighbor in return for the promise of assistance in time of need than have them become altogether unprofitable to him. So the kings found it more profitable to grant their extensive domains to their counts and dukes in benefice, in return for the doubtful advantage of their oaths of fidelity, than to attempt to hold them against men who seemed likely to get them anyhow. By the time of the Saxon emperors, practically the whole of Europe was organized on this system of vassalage. The Carolingian empire was intended to be an administrative system; the Ottonian empire was organized on this basis of fidelity and protection.

The strength of the feudal bond was not very great, but it was worth something for society. It helped to keep alive the sense of solidarity and provided a means of co-operation when special emergencies arose. The only real sovereigns were the lords of domains, but these were so united in a loose hierarchical order that, partly from a sense of obligation, partly by coercion, a general regulating system was maintained, so far as the external relations of the domains to one another were concerned. Within the domain the lord was supreme. When the public functionaries were forbidden to enter the domains, the proprietors found themselves the only possible judges. Therefore, they either acted in that capacity themselves or appointed agents from among the men of the domains. ${ }^{x}$ The slaves had always been under the jurisdiction of the master; now all classes on the domains were in the same position. The proprietor of the soil became the sovereign of all the men attached to the soil, and was governed in his dealings with them only by the customs that had grown up and by the interests of cultivation. He was an absolute monarch.

Ibid., 417, 4 18. 
The public authority had nothing to do with the organization. The domains were sustained by their own force. The independence of the local proprietor was not the product of the immunities, as Fustel de Coulanges is rather inclined to assert, but the immunities arose when the independence of the local proprietor had been largely developed. If in Germany the domanial system developed from below-was the outgrowth or degradation of a free tribal system-the conditions in the feudal period were the same as in Gaul, where it had been organized from above-was the result of the appropriation of villas by the conquerors as chiefs, acting in harmony with a central government. Throughout, the system was created, not by calculation, as Clovis and Charlemagne had thought a social organization could be produced, but by necessary and natural growth. The mediæval period was characterized by this formation of communities beneath the State. The State could later take advantage of the results of this unconscious social development and bring itself to correspond to the community formed independent of it. Thus, the State disintegrated and conformed to the agricultural communities. Later, with the development of commerce, new communities which were not consciously recognized in the existing political structure sprang up, and the political organization tended to conform to these new economic communities. The feudal system was nothing but an expression of the agricultural organization of the times. From agricultural independence arose political independence: hence the struggle between the seigneurs and the crown. In these struggles the lords were uniformly successful.

In perfecting the agricultural organization, the ecclesiastical and royal domains served as models to the smaller lay proprietors. At first, the monasteries were more important than the secular or even episcopal lords as organizers of agriculture. They depended more on rational organization than on personal power, and were anxious to follow the methods which the Romans had employed. The monasteries usually established themselves on waste lands, for the prime object of the monks was retirement. 
After the invasions, they had no difficulty in finding waste lands even in regions which had been most highly cultivated. But the company had to maintain itself, and also carried on manual labor for penance and discipline. Great saints could live holy lives as hermits; but when masses of men were gathered together, though they had come because of an impulse to lead lives of holy reflection, it became necessary for the leaders to lay down rules for practical activity. The poverty from which many of the monks came, the reverence of the Church for the Son of the Carpenter, and the necessity of labor for means of subsistence, all combined to give manual labor a high moral value in the monasteries. Accordingly, the monastic rules, all modeled more or less after the Benedictine, enjoined the duty of manual labor as a moral discipline. ${ }^{\mathrm{I}}$ Not only did the monasteries reclaim waste lands and bring about the most complete organization of agriculture, but they kept up many crafts as well, and were the chief agency by which the arts were preserved. Laboring for the sake of discipline, for the good of the order, and for the benefit of the poor and the pilgrim, their industry was more productive than that of the best-managed secular manors; and the monasteries first produced a surplus that could form the basis of commerce. From the sixth to the tenth centuries the monks were the chief agency in the extension of the agricultural organization, as well as the most effective disseminators of religion, in the more backward parts of Europe, and doubtless had much to do with the introduction of uniform methods of cultivation in sections where the Roman influence was never felt. The first duty of the Benedictine was always to cultivate the land.

As the monasteries grew wealthier, a revolution came in the management of their internal affairs. Neighboring lords would give them vast domains in return for prayers. The Merovingian kings were especially favorable to the monasteries, granting them estates from the royal domain, immuning them from the jurisdiction of the counts, and exempting their commerce from tolls. With the new domains came villeins whose labor was necessary

× Regula S. Benedict., xlviii. 
to make the lands worth anything. The humblest of the monasteries had to become manorial seigneurs. The wealthier were also finding a way to divide labor and make some members of the community mere laborers. By the time the feudal system was well developed, the division of labor among the brethren was pretty well advanced. The lettered monks devoted themselves to pious exercises and liberal studies, while the convers, or lay brethren, had to give themselves to manual labor in the fields and workshops. By a fiction, writing and illuminating came to be regarded as manual labor in compliance with the rule of the order. Ordinary labor ceased to be held in high honor, and the lay brethren were reduced to a state bordering on serfdom. After the tenth century the monasteries did not differ essentially from the secular domains, except that they were always the best managed. The part that had been played by the monks as free laborers, working for the good of their order, had much to do with the development of the best possible methods of cultivation in all parts of Christendom; and even after the monks ceased to be manual laborers, their more intelligent oversight of the servile population on their estates continued to raise the standards of manorial administration. In this last respect the episcopal influence was nearly as beneficial as the monastic.

Thus the religious organizations which stood for the ethical unity of Christendom, because of their inability to realize that unity in actual social life, attempted to realize it emotionally by retreating from society. But in their retreats they built up minor communities which could carry on the essential functions of life. In doing so they formed self-sufficient communities which were able practically to drop out of the political society. The ecclesiastical domains first and most completely became self-sufficient, not only in supplying themselves with the bare necessaries of life, but in securing a surplus that could be used in providing many luxuries from their workshops and in enabling many of the monks to devote themselves to religious and scholarly pursuits. The highest type of the manor is therefore to be found under

× Levasseur, op. cit., I, I44, I45. 
monastic lordship. ${ }^{\mathbf{x}}$ But these self-sufficient domains are chiefly interesting to us because they served as models for the agricultural organization of all sections of Christendom.

The organization of the royal domains likewise had a great influence on the organization of private manors, and had much to do with the development of the great fiefs which finally broke down the royal power. In all of the conquered countries, and especially in Gaul, the public lands were very extensive. These fell into the hands of the barbarian kings. The earlier Merovings were too crude to have much influence in organizing these domains on a profitable basis. Those which were best managed were under the direction of stewards selected from among the provincials. Many were appropriated by the Frankish counts to whose care they were intrusted. Charlemagne succeeded in getting possession of many of the royal domains, and carved out others from the Saxon territories which he brought into his empire. He organized them under the official nobility which he created. He brought his own great administrative genius to bear upon the problems of manorial organization; and his influence in shaping the development of Europe was perhaps more important, certainly more lasting, through his domanial organization than through his imperial organization. His managers could gather together more men than the smaller nobles could, and thus do away with many of the more primitive methods that had been employed in the German parts of the Frankish empire. Charlemagne used as his model the better managed estates in Roman Gaul, and attempted to extend the methods there employed to his estates on the borders of Gaul and in the interior of Germany. His influence on the agricultural organization was very great, because he held domains in all sections of his vast empire and made available to the more backward localities the results of the experience of the most advanced. Regardful only of the immediate interests of the royal domains, Charles did not foresee that he was simply laying the foundation of the power of the official managers who were soon to appropri-

${ }^{x}$ Cf. Guérard, Polyptyque d'Irmnon, I, 648 ff. 
ate the royal domains to their own uses. With an interest in the commerce that he was trying to develop, he was yet unable to stimulate a real circulation of commodities. The important commodities, nearly everything except a few luxuries, were still produced on the domains; so that, when he desired to increase the manufactures of his empire, there was nothing for him to do except encourage the manorial industries. His domanial policy, therefore, simply contributed to the greater independence and self-sufficiency of the domains. ${ }^{\mathrm{x}}$

Nevertheless, his efforts to improve the royal domains, though their outcome was quite other than he would have desired, were of greater benefit to the various populations of his empire than many of his most important acts of statesmanship; for when the darkest days came the domains were prepared to stand alone in every respect. The crown lands were scattered everywhere, and the methods which had been carried by Charlemagne's order from the better domains of the Romanic regions could soon be introduced by the great landowners of the various sections.

Thus the ecclesiastical and royal domains served as models for the organization of the other domains in whose neighborhood they were situated. The semi-intensive cultivation employed on those domains, and their production of all necessaries of life within the manorial community, made it desirable to have a considerable number of laborers on every domain. It therefore became more and more necessary to combine very small domains with larger ones. So the small holders commended themselves to their more powerful neighbors, and the holders of scattered domains exchanged estates in order to get their possessions under control. Then, when closely affiliated manors were not individually entirely self-sufficient, their inhabitants could never-

x Charlemagne's order was: "Ut unusquisque judex in suo ministerio bonos habeat artifices, id est, fabros ferrarios et aurifices, vel argentarios, sutores, tornatores, carpentarios, scutatores, precatores, accipitares, id est, ancellatores, saponarios, siceratores, id est, qui cervisiam vel pomatium vel piratium vel aliud quodcunque liquamen ad bibendum aptum fuerit facere sciant, pistores qui similas ad opus nostrum faciant, retiatores qui retia facere bene sciant tam ad venandum, necnon et reliquos ministeriales quos ad numerandum longum est."Capitulary de villis, xlv. 
theless supply their needs. Accumulation of wealth consisted in gathering together workers rather than products. These workers could be politically controlled because they could work only in small communities; and the feudal system meant the political organization based on relatively small agricultural communities.

Conclusion.-The interest of the lords in the organization of their domains only went so far as the gathering-together of the laborers and the organization of police systems. The lords were interested in war and politics, not in methods of industry. Though they were indissolubly connected with the manorial system, the work of industrial development went on without their supervision. The lords lost the immediate control of the agriculturists after the organization of the domains had been completed. The lands were broken up and given to men in tenure in return for services and products. Demesne lands were no longer worked by personal slaves. The estates were managed by ministerials who arose from the villein class. These supervisors became practically independent, except that they had to turn over a certain product to the lord. And the serfs became practically independent of the ministerials, except that they had to meet the requirements under which they held their tenures. The men were still under the legal control of their lord, but their condition within their industry was practically free. They could not leave the manor, nor could they neglect to render to the lord the designated products and services; but the products of their own tenures were their own, and they could conduct their industries as they pleased. All slavery disappeared. Proprietorship in the soil involved control of the men who were attached to the soil, but that control was political rather than economic. The returns to the lord took the shape of rents and taxes, rather than the exactions of a master of slaves. The small size of the domain gave the despotic lord scope for tyranny; but it was not to his interest to change the methods of cultivation. We may readily believe that the serf was practically as free in conducting the ordinary activities of his life as is the freeman under a despotic government. 
The individual could not stand altogether alone in his industrial activity, because he could not function for society as a whole. As in the moral sphere the Church had to mediate between the individual and the ideal, so in the economic life the institution, in this case the manor, had to mediate between the individual and the ideal of free co-operative activity in economic production. The individual could be free; but only within the institution which possessed the ideal. He was held within the manor, as a later class of workers was to find its freedom only within the gild. Only when the manor should no longer be the essential economic institution could that freedom come to have a larger content. As the individual has come to function for a larger and larger community, his individuality has widened. But in the freeing of the laborer's technique from the control of a privileged class of society, the real basis was laid for an individuality such as had never been known in ancient society. In antiquity the workers had been controlled as to their methods by efficient entrepreneurs, and the more valuable part of their product passed entirely beyond their control as consumers. In the Middle Ages the technique was entirely under the control of the workers themselves, and the product, while scant and coarse, was equitably divided between them and the military and political classes. The formation of the manors and the transition from slavery to serfdom must therefore be regarded as one of the greatest revolutions society has ever experienced. Beside this vital and growing freedom secured under feudalism, the legal freedom of the artisans of antiquity must be regarded as little above actual slavery.

x "La féodalité attaqua et détruisit la liberté individuelle des artisans, et, en les soumettant tous a la loi du servage, elle en fit des hommes de corps ou de poteste. Mais elle détruisit aussi l'esclavage qui, pendant toute la période romaine, avait flétri de son contact les artisans libres et déshonoré le travail, et que les Germains, après la conquête, avaient accepté et conservé pendant plusieurs siècles. L'égalité dans le servage prépara les hommes à l'égalité civile et à la liberté. Déjà, sous l'étroite dépendance dans laquelle les tenait le seigneur, ils travaillaient, amassaient jouissaient, du moins de leur vivant, d'une partie des revenus de leur industrie comme d'une propriété légitime. Bientôt même ils purent avec leurs économies acheter l'exemption de quelques servitudes, fixer les limites de leur obeissance et échapper à l'arbitraire de leur maitre. Quelques-uns enfin, plus 
In the foregoing discussion the development of the freedom of the serfs is attributed to the fact that the industrial processes could not be controlled by barbarian society; that is, it came about by the development of the manorial system. While this economic development was the main cause, one other important factor must not be overlooked, namely, the teaching of the Church. The influence of the Church has frequently been overestimated in discussions of this subject. The Church was powerless to change servile conditions in the organized society in which it first worked. It would have been impossible for the Church to exert any such influence in barbarian society but for the conditions already described. The doctrine of the Church concerning the value of the individual was, as we have seen, expressed only emotionally. In explicit teaching the Church took the position that slaves should submissively remain slaves until the coming of the Lord, or until the future life was entered. But when the Church was practically engaged in dealing with individuals, its influence always tended to ameliorate the condition of the slaves. Christianity taught that both master and slave were to be judged by one law and that a slave might be adjudged superior to his master for all eternity. This belief had equal hold upon the minds of both masters and slaves. Marriage was regarded as sacred for slaves as for freemen. It took place in the church under the blessing of the priest. The slave could enter the priesthood and might rise to high position. Masters were encouraged to enfranchise their slaves under promise of future blessings. This doctrine of the spiritual equality of all men had considerable influence in curbing the barbarian lords, even though it could not do away with slavery at once. The Church did not demand the enfranchisement of slaves, both because such a revolution was practically impossible, and because the important thing with the Church was not human equality here, but a complete realization of the brotherly relation in the New Jerusalem.

heureux que les autres, entrèrent dans les cadres de la féodalité, et acquirent par leur travail des droits féodaux analogues à ceux que donnait la propriété territoriale."-Levasseur, op. cit., I, r70, I7I. 
A further result of the teaching of the Church was a change in the view taken of labor. Labor was given a dignity unknown before. The disciples of Jesus never wholly forgot that the founder of their faith had been a carpenter; and the value of manual labor as a discipline was also recognized. But when all this is said it must still be remembered that the most the Church could do was to hold up an ideal of personal worth which could moderate the spirit of masters and assure a fair observance of custom in the management of their domains. Directly, the Church was neither anxious nor able to disturb the status of any class. Only the application of Christian principles in detail and the reciprocal action of the political and economic movements we have traced, could elevate the slave to serfdom and prepare him for freedom.

When the agricultural organization was completed with the full development of feudalism, the various little communities into which society had broken were each capable of supplying practically all of the wants of their members. Commerce was extinct, except in a few sacred relics, some furnishings for the churches, a few articles of luxury which passed through the hands of the Jews, and, in some sections, iron and salt. The only exchange of importance went on within the manors. Money was not needed and did not circulate. A period of darkness which caused men to think the world must soon come to an end extended from the time of Charlemagne to the eleventh or twelfth century. But this was really a period of reconstruction. The agricultural system was being developed; the very system which seemed responsible for this disintegration was furnishing the remedy. A surplus was soon to be produced on the domains, which would cause the reopening of the channels of communication and the reorganization of the civilized world. Until this surplus should be produced, the unity of Europe could be found only in its ideals, and but little could come of the impulse toward social organization found in the conception of the Carolingian empire. Europe had exhausted the wealth received from the Romans, and now had to wait for the development of the agri- 
cultural and other industrial processes before the larger social life could be realized. Within the domains the manorial industries supplied every want; but as the peasants became able to produce a surplus from the fields, more persons could be withdrawn from agricultural work to engage in the simple manufactures of the community. Thus there was produced not only a surplus of raw materials that could be exchanged for manufactured commodities produced elsewhere but a surplus of coarse manufactures that could be exchanged for the finer goods brought by merchants from the South and East. The real basis of a general European trade seems to have been the coarse cloth of northern Europe, which was taken up by the Italians to be worked over; but this coarse cloth was the result of a surplus produced under the domanial economy. When the surplus was secured and commercial relations were re-established, the communities of Europe became interdependent again. Then, the mediæval agricultural organization was broken down, and with it the feudal system, and a larger unit formed, more nearly corresponding to the larger economic community. And when wealth no longer consisted in carrying over the workers, the latter, except in a few cases of arrested development, were entirely freed from the control of the lords, and were able to make their own contracts through gilds. Manorial services and returns were commuted for money rents, and the serf became a freeman. 


\section{CHAPTER IV}

\section{THE DEVELOPMENT OF COMMERCE}

The next necessity after that of intensive cultivation was the development of an exchanging system by which products could be transferred and placed at the disposal of the whole community. Society had disintegrated only that it might find the means for a new and more organic integration than had ever before been known. The reunion of the scattered fragments of Christendom was brought about chiefly through the agency of commerce.

Commerce did not immediately disappear when the Empire was invaded. From the second half of the third century the civil wars, the enfeeblement of the central power, and the incursions of the barbarians greatly reduced the opportunities for the exchange of commodities in the regions where commerce had been most highly developed during the three centuries preceding; and yet both on the Roman roads and on the waterways there remained a considerable degree of commercial activity during the later years of the Empire and the earlier Merovingian period. Maritime trade continued to be carried on from both the Atlantic and the Mediterranean ports of Gaul, and between Italy and the East. Many of the Roman cities of Gaul survived the fall of the Empire for some time, and continued to be centers of industry and commerce. The writings of Gregory of Tours (died 595) show that Gaul was still a country of cities, and that many of them were enjoying considerable prosperity. ${ }^{x}$

However, this condition of affairs could not last long. The continual wars, the pillaging of the cities, the robbery of traveling merchants, the neglect of the roads, soon caused a complete collapse of all internal commerce in Gaul, though communication with the East was kept up by the Mediterranean ports of both

I Levasseur, op. cit., I, I53-56; Pigeonneau, op. cit., I, 59-6r; Pirenne, Revue historique, LVII, 58; Gregory of Tours, Historia Francorum, ii, 14, 15; iii, 34; vi, 32, 4r; ix, 9, cited by Pirenne and Pigeonneau. 
Gaul and Italy until the Saracen corsairs began to sweep the seas. After many years of fratricidal wars among the Merovings, there was a period of calm after Chlothar had got rid of his Austrasian and Burgundian rivals, and in 628 had left the rulership of all the Frankish realms to an adult son. Moreover, this son, Dagobert, associated with him in the government the two progenitors of the Carolingians, Arnulf, bishop of Metz, and Pippin. While the royal power was decaying, there was a period of comparative order, helped on, perhaps, by the wars which Dagobert carried on in Spain and beyond the Elbe; and during this reign the great fairs were established and largely patronized, and commerce became temporarily active. But under the later Merovings the movement toward the establishment of the domanial system is sufficient evidence that municipal and commercial life was virtually extinct. Communication with the East was not entirely cut off, and some few of the arts of luxury were carried on; but the greater part of the trades disappeared entirely, while the workmen became serfs and monks.

There was another temporary revival under the earlier Carolingians. The order and internal security established under pressure from without and upheld by exceptional rulers made possible some degree of industrial and commercial activity. The cities had now disappeared, but royal ateliers were revived in connection with the reorganization of the agricultural processes on the royal domains. These workshops, however, probably contributed little material for commerce. Commercial relations were reopened with England and the Orient. Oil, wine, cereals, metals, cloth, and skins were exchanged for spices, pearls, gems, silks, and cottons. The opening of a new country by the conquest of the Saxons gave an opportunity for exploitation by merchants and missionaries. ${ }^{2}$ All the records of the period indicate a commercial activity such as had not been known for five centuries. There can be no doubt that the restoration of order had led to a real revival of productive industry. But there is nevertheless strong reason for believing that a great deal of the commercial activity

2 Pigeonneau, op. cit., I, 71-76. 
was artificial, like the administration itself. The exports from the Frankish empire were nearly all raw materials, and the imports were all luxuries. Such a trade is safe only when a large surplus of raw materials is produced and when the home industries have become somewhat diversified. At that time it meant that Europe was being stripped of its slight surplus of agricultural products-made possible by a few years of order-in order to gratify the desires of the nobles who had received a vision of the splendor of the past. Since the imports were luxuries only, the consumption of the masses could not become more diversified, nor was a stimulus given to the development of European industries. It was a period of artificial commercial activity based upon the extravagance of the nobility. Had it been based upon real production, not even the disorder of the succeeding period should have been able to destroy all commerce so suddenly. If, however, the domains were being stripped of every available product to gratify the ambition of the great monarch and his nobles for a brilliant reign that would reproduce the chief characteristics of Rome, it would be impossible to keep up the activity when the times of stress came. Like the commercial activity of Israel under Solomon, when the country was exhausted to gratify the magnificence of the king, the prosperous times under Charlemagne left Europe in possession of a few gems and a good deal of worn-out finery, but with such a narrow margin of the necessaries of life that the government could no longer maintain its finances and the Empire could not stand a siege without being reduced to misery. Charlemagne certainly did much for the development of the domanial system, but the short period of partial quiet was insufficient for a revolution in agricultural methods. A great surplus for exchange had certainly not been created. No cities were re-established, and no artisan class could be maintained apart from the domanial industries. Charles failed to restore the currency, and the precious metals continued to grow scarcer. We must conclude that the commercial activity of the time was largely artificial, and that the country was simply using up its resources. This artificial commerce, like the artificial 
administration, may have served to strengthen the ideals held by Europe, but neither had a permanent value in itself.

Whatever the value of the commerce of the reign of Charlemagne, during the anarchy of the ninth and tenth centuries commerce disappeared as completely as the imperial government. The foolish policy of dividing the sovereignty among the sons of Louis the Pious, and especially the favoritism of that ruler for his youngest son, inevitably resulted in civil wars which even a stronger central power would have found difficulty in suppressing. And in the midst of this breakdown of the administrative system of Charlemagne, Christendom was attacked from without on all sides at once. The Danes who had been checked by the Saxons began to give Charles trouble as soon as civilization had been pressed up to their borders. They learned the weakness of the Empire during the reign of Louis; and before the middle of the ninth century, they were scouring all the northern and western coasts of Europe and were ravaging the country to the headwaters of all the streams that flowed into the sea. For a brief period they forsook the continent to endeavor to establish a permanent kingdom in England; but thwarted in that purpose by Alfred, they again became marauders on all continental waterways, even penetrating the Rhone. At the same time, the Saracens, who had established themselves along the whole south coast of the Mediterranean, took to the sea, and now as pirates preyed upon commerce and ravaged the coasts of Italy, now as conquerers established themselves in Sicily and Benevento and threatened to overrun the whole peninsula. In the East, the Slavs and Magyars made continual aggressions upon Bavaria and Saxony. At one time Saracens from Spain who, had established themselves in Provence raided the whole Rhone valley, and at Orbe engaged in battle a party of Magyars who had crossed from the Danube. Torn by internal dissensions, attacked from all quarters by heathen and infidel, wholly lacking in political leadership and military resources, it is not strange that Europe sank to a condition worse than that of the worst Merovingian days. Under these circumstances commercial inter- 
course was manifestly impossible. Nothing of promise was left except the agricultural communities described in the last chapter. The feudal castle which belonged to this system finally proved the salvation of Europe. When these strongholds had been spread over the land, they served as places of refuge for the people and effectual barriers to the marauders. The Saracens ceased to give trouble except on the Mediterranean; the Slavs and Magyars were kept in check and finally Christianized; and such of the Norsemen as did not find permanent settlements in England and Normandy were obliged to give up their piratical descents upon the coasts of France and Germany and settle down in their own countries. Europe obtained security from external foes, but at the cost of complete political disintegration; and the constant feudal warfare that followed the establishment of the system was, for a time, as destructive of commerce as the piracy had been.

\section{PREPARATION FOR COMMERCE}

Now, in spite of the disorder which had troubled Europe from the time of the first invasions, there was never a time when commercial intercourse was entirely wanting. Aside from the restricted exchange in local spheres of salt and iron, there were a few feeble movements of commerce which served to prepare the way for a renewal of actual commercial intercourse. During the whole period from the end of the sixth century to the eleventh, the Jews and certain merchants from the East known as Syrians carried on a casual trade in oriental luxuries and handled about all the money that circulated. The Jews came into great prosperity during the period of most complete disorganization. United by faith and by common traditions, in constant communication with their co-religionists in Spain, Italy, Africa, and the Orient, they formed an organic body in the midst of universal dissolution; and freely employed the commercial instincts which had been developed by necessity and education. The very action of the Church upon the lay society contributed to their prosperity. The canons of the councils and the royal capitularies in denying 
to Christians the right to exact usury, that is, interest on loans, assured to the Jews a monopoly of the money business. Through their intimate relations with the Mohammedans, who always treated the Jews with a toleration which they could never show to the Christians, they were able to communicate with the East at a time when no Christian could sail upon the Mediterranean. In some of the remaining cities of the south they maintained quarters and were governed by their own rulers. The Church and the princes condoned their offenses against Christian morality because their services as money-lenders and dealers in valuables were indispensable. They were found also dispersed throughout the country, and on the domains plied their trade as pawnbrokers among the villagers and brokers for the lords. The great seigneurs controlled Jews just as they controlled serfs. ${ }^{\mathrm{x}}$ In England the Jews belonged to the king, and great nobles were forbidden to take them into their service without the king's leave. ${ }^{2}$ But though the business of the Jews was profitable to them and had some importance as a stimulus to greater demands for luxuries, it can hardly be considered a part of the commerce of Europe. Money borrowed from them at exhorbitant rates was used only in consumption. There was no such thing as capital except land and agricultural implements; and the Church was justified in attempting to suppress usury. The trade carried on by the Jews was in such commodities as spices, perfumes, silks, tapestries, precious stones, and jewelry, and was of little importance to the social development of Europe. In return for these luxuries the Jews gathered up about all the coin and most of the gold and silver ornaments that had been preserved from Roman times. A small quantity of wine and oil was exported from southern Gaul and a few valuable furs from the northern countries; but the total volume of commerce was of practically no economic importance, except as serving to cultivate a taste

I Pigeonneau, op. cit., I, 66-71, 104-7. Cf. Grætz, Histoire des Juifs, III, $\mathrm{IV}, \mathrm{V}$, in loco.

2 Law of Henry II purporting to have been established by William I.-Annals of Roger de Hoveden, I, 553. 
for certain luxuries that was afterward to lead to more vital operations.

Because of their separation from the mass of the population and their tendency to keep aloof from any but their own race, the Jews contributed little to the keeping up of a means of intercourse between the various sections.

This latter preparation for the revival of commerce was made by the Church. The importance of magic in the work of the Church made it desirable to transport sacred relics from place to place; and the need of pictorial services required the transportation of church furnishings from Byzantium and Italy to the less advanced communities. Thus the Church kept up a certain amount of commerce. This had no more economic significance than that carried on by the Jews, but it served to keep up communication between the different sections. For the manufacture of glass and the erection of the earlier buildings artisans themselves had to be imported from the East and South. Along with the commerce in relics, there was a constant intercommunication in certain sections through pilgrimages to noted shrines. When the special festivals were held at these shrines on the day set apart for the saint, large numbers of pilgrims would be present at the same time. The provisioning of such a company would occasion considerable trade, except when the monasteries were prepared to care for all their guests; and even if provisions could be supplied by the monasteries, peddlers and traders would naturally join the pilgrims as soon as there were any peddlers and traders. Sometimes the monks were themselves traders. Sometimes men would bring their simple manufactures from domains in the neighborhood. Finally, when regular peddlers arose, as will be explained later, they flocked to such gatherings. In some instances the important fairs sprang up at these favorite shrines. But, aside from the trade which was carried on among the pilgrims, the pilgrimages themselves kept up communication between points which could no longer come in touch with each other through their armies. Again, the Church maintained its organization much better than the Empire did; and although during 
the darkest period, at the close of the ninth century, the Church was itself very much disorganized, there was never a time when the Pope did not have frequent communication with the scattered dioceses, or when the great orders did not maintain their solidarity. The superstitious awe in which the Church was held made it possible for priests and monks and messengers and pilgrims to travel from place to place as neither merchants nor soldiers could do. Even the Saracens in Palestine treated with respect the Holy Sepulcher and the pilgrims who visited it, until fanatical sects and, later, the Seljuks came into control of that country. Thus the commerce of the Church and the travel inspired by the Church served to keep open routes which were closed to ordinary travelers, and to bring into communication regions that were too remote from one another for military contact.

The episcopal cities were also centers of somewhat larger transactions than those which took place on the ordinary domains. These places were not really cities in either the ancient or the modern sense of the word. They were merely centers of domanial exploitation. Since the bishop and his attendants did not ordinarily move from one domain to another to consume the products of each in turn, as the lay nobles who held several domains did, the products of the surrounding manors belonging to the see had to be transported to the residence of the bishop. ${ }^{x}$ There was thus maintained a kind of industrial concentration that might form the basis for new city life. This activity was not commercial, for nothing went from the city to the manors: it was simply the gathering of the returns of many manors in one place for the support of the clergy and the small population that labored for the maintenance and adornment of the cathedral. In these various ways the churches and monasteries contributed largely to the commercial development. But they simply prepared society for a revival of commercial activity by keeping up. communications and by furnishing inns for travelers: they were not themselves actually engaged in commerce.

r Pirenne, Revue historique, LVII, 60-62. 
Attempts to study the development of commerce have usually been unsatisfactory because they have failed to distinguish between real commercial activity and the mere external mechanism of ships and roads and travelers. The valuable work of Pigeonneau, like others of less note, does little more than give us certain clews to indicate that certain important movements were going on. The real history of commerce which will some time be written will give some account of the production that has fed commerce, as well as a description of the condition of the routes and of some actual exchanges which indicate that commerce has actually been going on. The three phenomena described in this section-the commerce stimulated by Charlemagne, the transactions of the Jews, and the intercourse kept up by the Church-are but superficial. They do not indicate a genuine commercial activity. It is, however, with such phenomena as these that historians of commerce have largely concerned themselves. They are worthy of note, but only as guiding the student to a deeper study of the dynamical phenomena of which these are but surface indications. Real commerce represents a differentiation of function by which the diverse parts of society come into complex and organic relations with one another. Such commerce could not begin until the various local agricultural units into which Christendom was divided began to produce a surplus of the necessaries of life to exchange for similar surpluses produced by other communities or for more highly finished products from more advanced communities. The more essential the commodities of exchange become to all members of society, the more completely does commercial activity represent the differentiation of function. Until that kind of exchange became general, the economic relations of men were recognized only in terms of the narrower community life; just as they are today among low barbarian tribes. There was no consciousness of the larger social relationships growing out of the essential functions of life. The Church alone stood for this consciousness of relationships which ought to exist, but which could not be recognized in the ordinary social activities. 


\section{THE BEGINNING OF COMMERCE}

The developement of the agricultural organization as traced in the last chapter was the true preparation for commerce. By the eleventh century, the full establishemnt of the feudal system and the cessation of piratical raids had brought about a comparative peace, while the increased productivity of the fields of the domains was making possible the withdrawal of some of the serfs from the fields and the exchange of surplus commodities. The industry of the serfs was producing a surplus of certain commodities of prime necessity; and as these products were not suitable for export to distant points on account of their bulk, the tendency was to withdraw a greater proportion of the laborers from agriculture and to turn them to manufacturing for the domain to which they belonged. The great lords, especially the ecclesiastical ones, carried over such remnants of industrial skill as could be found after the overthrow of the old civilization. The products of the domain were used in the manufacture of practically everything consumed, and the artisans had to be the serfs of the domain. Spinning and weaving had to be done everywhere. The crafts of the carpenter, miller, smith, and baker were plied in every manorial village. Much of this work could, of course, be done by men who devoted most of their time to agriculture; but as the latter industry became more productive, the villeins could cultivate less ground and thus have more time for their weaving, or some could withdraw from cultivation altogether and exchange the products of their looms for the products of their neighbors' fields. As a matter of fact, both changes took place; but the latter became much more important. If, as was the case on large domains and in monasteries, there were persons who devoted their time chiefly to work in the ateliers, this class could be increased when the fields began to produce a surplus. The inhabitants of the domain could thus be better clothed, and in time could produce a surplus of cloth for exchange. In the great monasteries the cloth industry became very important, because their workmen could first produce more than was needed 
for home consumption and also because they were able most easily to exchange their surplus at the fairs. In Flanders the cloth industry developed more rapidly than in any other part of northern Europe, and became the basis of commerce with the Italian cities. The development of the Flemish woolen manufactures was made possible by the ease with which raw wool could be secured from England by these workmen who had withdrawn from agricultural pursuits. In southern France wine and oil were the chief products of the domains first produced for exchange. The textile industry was the first to become important for commerce, because it supplied a universal and almost insatiable want, and its product could be kept an indefinite time and transported to great distances more easily than most other commodities. Food products were in equal demand, but they could not be transported very far because they would not keep.

A surplus of the necessaries of life being assured by the domanial economy, the next step had to be the creation of new wants. This could take place only slowly; for it meant not only the demand for luxuries on the part of the nobles, but the desire for generally better subsistence and clothing on the part of many of the lower classes. The development of new desires could go on gradually and naturally, because the increased supply came so gradually. A sudden increase in the resources of the nobility without a corresponding increase in the independence and economic power of the producing classes would have resulted in such an abnormal kind of production as had existed in Greece and Rome in the days of their greatest prosperity. As it was, although the luxuries brought to the nobles from the Orient had much to do with the development of new wants, the economic demand was nearly universal because the men who were giving more and more of their time to the production of new commodities were freed from old feudal obligations and advanced to a superior economic and social position. Indeed, after the towns were established, the chief economic demand came from the town populations and not from the nobles. The museums of Europe still show us how superior were the furnishings, clothing, 
and weapons of the burghers to those of the feudal aristocracy with whom they contended. On every domain the work of blacksmiths, carpenters, masons, armorers, shoemakers, wheelwrights, saddlers, etc., became more and more important and more and more specialized. The men who followed these trades were able to give up the cultivation of the fields and to receive liberal compensation from their lords and the peasants of their domains for their services. Frequently the artisans were able to hold their positions as fiefs which remained in their families for several generations. ${ }^{x}$ The lords received from their own artisans many of these new commodities, which were fast becoming necessaries, while other products could be exchanged for finer commodities brought from the South and East. Raw materials could also be exchanged by the peasants, since the danger of famine no longer made it so necessary to keep a surplus on hand. Thus the peasants were able to sell a litttle grain or wine or oil or homespun cloth; and since the lord no longer cared for returns in kind and was very anxious to secure ready money to satisfy his increasing desires, he was glad to commute the old manorial services and dues for money rents. This tendency was most marked where the industrial movement was most advanced. By the thirteenth century serfdom had disappeared from Flanders, Normandy, Picardy, Artois, and the greater part of Orleans and the Isle de France. $^{2}$ Every step forward by the industial classes led to increased production.

In the episcopal cities the same industrial activity was found. These cities, as has been stated, were but the centers of domanial exploitation. Since the bishop and his attendants remained permanently located in one place, many of the industries carried on on the domains had to be transferred to the episcopal residence. These places were not cities, but they were centers of greater activity than any of the ordinary domains, both because they were centers for many neighboring domains and because the demands of the bishop were greater than those of any ordi-

I Levasseur, op. cit., I, I I3-16, 167-69.

2 Pigeonneau, op. cit., I, I 7 I, 172. 
nary lay nobleman. Provisions had to be carried to the city from the domains belonging to the see for the support of the numerous population assembled about the cathedral; and the aggregate amount of industry in the city was usually greater than that of many domains combined, for there were extra services required, such as the manufacture of parchment and of furnishings and vestments for the cathedral. The building of the cathedral itself was a much more important undertaking than the construction of the feudal castle, and often involved the labor of a good-sized village for several generations. It is true that the great church-building operations did not begin until the twelfth century, when the expanding genius of the people best expressed itself in religious architecture; yet at the very beginning of the commercial period, the increasing wealth of the episcopal estates was devoted to the beautifying of the cathedrals. Consequently, large companies of workmen were gathered and diversified industries carried on. An increased demand was also created for the articles which had to be imported for the furnishing and beautifying of the church-to be paid for out of the resources of the episcopal domains and from the contributions of the faithful of the diocese.

All of this domanial activity was purely local in its beginnings. It started up spontaneously in every section at about the same time; but immediately it represented only local prosperity, and might have continued to exist without doing away with the selfsufficient local communities. However, it was the nature of such productive energy to find an outlet for its products, and, by the opportunity to secure the products of other communities, to receive a stimulus to greater productivity. Such, at any rate, was the case in this instance. This brings up the question of the nature of the exchanging organs.

We have seen that there was always some little intercourse between even distant regions through the pilgrims and traveling traders. A few fairs and markets were frequented throughout the darkest period, and a continuous though trifling trade was kept up by the wandering merchants. The little cargoes of grain 
and wine, representing the surplus production of the great domains, were transported up and down the Rhine, the Maine, the Seine, and the Loire, and disposed of at good profit where they happened to be most needed. Other traders carried their wares in a single pack, and made their bargains wherever they had opportunity. These merchants were almost the only people in Europe not attached to the soil. They lived a sort of vagabond existence, continuing to ply their trade from the time of Charlemagne to the beginning of the eleventh century. They were protected by the imperial power until that power disappeared, and after that by the Church. They almost drop from view during the period of anarchy, and appear in considerable numbers upon the routes only with the revival of commerce. ${ }^{x}$ They were ready to take advantage of the opportunity for gain presented in the growing excess of products on many of the domains. Many of them, as we have seen, were Jews. Others of the earlier traders were from the Eastern Empire. Later, we note the appearance, in northern Europe, of merchants from Italy, known as Lombards. Probably there were always a few who had escaped from serfdom; and as soon as opportunities for profitable trade increased and it became safer for men to detach themselves from the domains, their numbers were more largely augmented by men who were attracted from the manors by the wandering life, and by villeins who were the producers of commodities handled by merchants, which the producers thought they might as well try to dispose of themselves. Serfs could either run away from the domains, or obtain permission from their masters to engage in the new business on payment of a fine. Thus a class arose whose business it was to carry on the exchanging activity. They had to travel in caravans to protect themselves from brigands, and were subjected to heavy feudal tolls for the right to sell on the domains and for pretended protection in passing through the estates; but their function was too important to society to be entirely destroyed.

Thus, both of the elements of commerce were provided. From

I Pirenne, Revue historique, LVII, 7I-73; Inama-Sternegg, op. cit., I, 447-5 I. 
this point the development was assured. The European industrial communities were at last in a condition to send a portion of their products away; and the means were found, through the merchants, for making the exchanges. The process having once been fairly started, it was bound to go on indefinitely. The basis was laid for a division of labor extending beyond the single domain. It was soon to be possible for many of the domains to give up attempts to produce certain crops or to manufacture certain commodities for which they were not adapted, while by turning their whole energy to the production for which they were well adapted, they would secure ample means with which to provide themselves with all else needed.

The trade which was developed was of a twofold naturean exchange of food products and coarser manufactures between the various sections of northern and western Europe; and an exchange of the raw materials and coarse cloth of those sections for the richer commodities handled by the Italian merchants. The more local commerce consisted in the exchange, within relatively narrow limits, of the ordinary food products, salt, metals, wool, linen, fish, etc. Woolen cloth was extensively manufactured in the Low Countries, to be exchanged for raw wool with England, on the one hand, and with the neighboring continental regions for food, on the other. The trade with the Italian cities was chiefly in the wines of France, the wool of England, the woolen cloth of Flanders, and the skins, furs, and other raw materials of the Baltic regions. Every new avenue of trade that was opened up revealed new opportunities for profit. The various communities began to pursue the industrial activities which seemed most profitable to them, and an interdependence was established which has never since been broken.

\section{THE RISE OF THE TOWNS}

The development on this side seems simple enough, but when we come to consider the effects of the commercial activity on the general social life, and especially on the political structure, we are confronted by many complicated problems. The phenom- 
enon most closely connected with the development of commerce was the rise of towns. We have seen that the basis of commerce was laid on the feudal domains and in those old cities which had become mere centers of neighboring domains. Now, however, we find springing up everywhere towns which become not only centers of industry and commercial centers, but self-governing communities as well.

The best starting-point for the consideration of the rise of the cities seems to be that suggested by Pirenne; namely, that the wandering merchants formed permanent settlements at points where afterward sprang up the free towns. Says this writer:

If the merchants of the Middle Ages were always travelers, it is nevertheless evident that they must have resided at definite places in the intervals between their trips or during the bad season. It was naturally in the localities whose situation was best adapted, by facility of communication, to the necessities of commerce, that they would group themselves in great numbers. In the ninth century more or less numerous colonies of merchants existed at places along the Rhine, at Worms, and especially at Mayence, on the Meuse, at Verdun and at Mrstricht. In the tenth century, in spite of the misery of the period, these colonies had not entirely disappeared. Certain cities bear in the sources the name emporium-as Paris, Bruges, Dorstadt, etc.-and we may suppose that in a great many of them, as at Verdun, there was a negotiatorum claustrum, a fortified inclosure behind which the merchants found protection against the robbers without. In proportion as tranquility was re-established, the number of merchants was increased, and these settlements became more numerous and more important. Wherever the conditions were favorable, an urbs nova, a surburbium, a commercial suburb, was formed beside the château and the immunities, the ensemble of which constituted the town of the agricultural age; and the fact that this suburb, the point of departure of the new town, had a merchant population is proved by the language of the time in which the words mercator and burgensis were synonymous. It was the merchants who constituted the earliest bourgeoisie. The latter class did not arise from the servientes, milites, and ministeriales, who had been fixed for centuries about the cathedrals and abbeys; nor can its origin be sought in the censuales, who in a number of ancient cities were found under the power of the public functionaries or the patrons. It constituted essentially a social class. It was composed of advence, free or unfree, who, abandoning the cultivation of the soil, came in greater and greater numbers to find in commerce and industry a new means of existence. The juridical condition which this class finally secured was but the necessary consequence of the life which it 
led: just as the military trade had made of the man of arms a noble, and the cultivation of the soil had everywhere made of the peasant a serf, so the exercise of the profession of commerce made of the merchant a burgher. ${ }^{x}$

Where the merchants lived when they were but a class of pack peddlers is a matter of small importance. Some of them may have been villeins who were permitted by their lords, on payment of a fine, to carry on their trade. This was the case with some of the Jews. Others may have been agents of churches or religious houses. In these cases the permanent homes of the merchants were in the neighborhood of their masters' residences. Others who were mere wanderers may have formed little settlements in the old cities, ${ }^{2}$ doubtless paying tribute to the seigneurs. Those who came from the South doubtless returned to Italy after their business was completed. But when the commercial operations became so much more important, it became necessary for the large number of traders to have settled places of abode, both as residences during the bad seasons, and as places where they could conveniently collect their merchandise. To these places the men from the domains would go until, finally, a small colony was formed of persons who devoted their whole time to trade and who had thrown off all but nominal allegiance to the feudal lords. The step that would naturally follow the establishment of the commercial settlement was the preparation of goods for the market, involving the gradual collection of a population of artisans and the development of industries far more important than those of the old domains which had furnished most of the first commodities for commerce.

Pirenne's explanation of the origin of the town population commends itself as a purely natural one. It carries with it the further suggestion that we are to find the reasons for the location of the towns in geographical, rather than historical, considerations. It is true that many of the new towns grew up on the sites of the old Roman cities, but this was only because the old cities had formerly been favorably located for commerce, as at

I Revue historique, LVII, 73-75.

2 Giry, Établissements de Rouen, I, 3. 
the crossings of the great highways, at the points where highways touch the rivers, at the mouths of the rivers and at the head of river navigation, at points where two rivers flow together, at points where two rivers flow nearest to each other, where the shortest portage was possible. If a castle afforded protection or a monastery drew people together, the place would be all the more desirable as the headquarters of a company of traders; but no place became a town merely because of the existence of city or castle or monastery, and many towns sprang up at such points as those just mentioned though no city or castle or monastery had existed there before.

The theory that the old Roman cities survived and had a continuous municipal life has been pretty generally abandoned. Except, perhaps, in Provence and Italy-and probably only in Greek Italy - no remnant of the old municipal institutions lasted through the feudal period. The new towns were not the natural descendants of the old cities, even when they sprang up as suburbs of the latter. Whatever influence the Roman cities may have had as episcopal residences, they probably had not the slightest influence in forming the commercial cities which began to spring up in the eleventh century. ${ }^{x}$

Nor is it true that the towns developed from the villages of the great domains, or under the influence of domanial law from the ancient cities. The domanial economy had prepared the way for the new epoch, but the domanial structure tended to resist alterations to suit the changed conditions. Where the seigneurs had the greatest authority, as in most of the episcopal cities, the communes met with the most serious opposition; while the development of the towns was usually peaceful where the jurisdiction of the seigneur was loosest, as in Flanders. Whether one of the manorial villages grew into a commercial town, or an old Roman city was transformed into a modern commune, the change always depended upon the infusion of a new element. The merchants frequently managed to exist beside the older orders, but only as the latter were drawn into the

I Flach, Origines de l'ancienne France, II, $226 \mathrm{ff}$. 
new commercial movement did they become a part of the new town. ${ }^{x}$

Neither can abbeys or castles be considered the germs of the towns. If they had been, then the more powerful and renowned the monasteries and forts, the more rapidly would towns have sprung up under their walls. In many instances towns did grow up where monasteries or castles had been established at very early dates; but many of the most famous monasteries and strongest castles never became cities. Neither at Cluny, Clairvaux, nor Fulda was a city formed. Monks had sought retirement, and built their cloisters in unfrequented places. If their prosperity drew merchants to them, nevertheless towns did not grow up about them unless they had by accident been favorably located for commercial purposes. Some abbots tried to stimulate the development of towns by granting exceptionally liberal charters, but they failed unless the natural situation was favorable. So also, the strongest castles were usually built in unfavorable places for commerce. Having been located for purely military reasons, they were usually erected in the most inaccessible places. About some forts, whose situation was found to answer the needs of commerce, urban settlements were formed; but the presence of the castle was as incidental as that of the monastery. ${ }^{2}$

Finally, it may be shown that the towns did not orginate in the fairs or permanent markets. Cities did not ordinarily grow up about the great fairs. The fairs were simply rendezvous of merchants, in many cases located at famous sanctuaries where many pilgrims came at certain times. They had no necessary relation to settled populations or prosperous domains. After the feasts pilgrims and merchants alike dispersed. The markets which were established in great numbers in the early part of the eleventh century were indicative of a revival of commerce; but they were simply meeting-places for local populations, as the fairs were for more general gatherings. Though held more fre-

× Pirenne, Revue historique, LIII, 57-6r. Cf. von Below, "Zur Entstehung der deutschen Stadtverfassung," Historische Zeitschrift, LVIII, 234 ff.

2 Pirenne, Revue historique, LVII, 65, 66. 
quently than fairs, they did not produce cities. These were frequently established by the seigneur or prince for purely fiscal considerations, and were seldom located at suitable points for permanent commercial settlements. When the towns arose, they always had their weekly markets to which the peasants of the surrounding country carried products for the subsistence of the burgher population and where the craftsmen and traders displayed their wares. But these town markets were not of ancient date. They were established only after there were cities to be provisioned, and in no sense caused the location of a city. Attempts by the seigneurs, as at Radolfzell and Allensbach, to fix a population of merchants at markets belonging to them in no case resulted in the birth of a city. ${ }^{x}$ While, then, a city may occasionally have arisen on the site of a great fair or seigneurial market, yet, as in the case of towns which sprang up about the old cities, the castles, and the monasteries, these exceptions are to be explained solely on the ground that the fairs or markets in question were favorably located for trade.

The market theory of the origin of the towns usually involves the theory that the king's peace protected the merchants attending the fair or market, thus facilitating trade and laying the foundation of urban law. The law of the market is supposed to have become the urban law, and the equality of all merchants before the law of the market is supposed to have led to an equalization of their position when the town grew up. Thus, royalty is held to have created the towns. The royal protection which Charlemagne threw around the merchants is supposed to have continued until the towns arose, and to have brought especially heavy penalties upon the disturbers of the peace; while the same power is held to have given the merchant population the right to establish its own magistracy to enforce the law. The town was thus a Königsburg. ${ }^{2}$ But such a theory assumes a central power such as did not exist during the formative period of urban insti-

I Ibid., 66-68.

2 On the Stadtfriede and the Stadtgericht, vide Sohm, Die Entstehung des deutschen Staddewesens, 34-7I. 
tutions. The "king's peace" probably did not extend beyond the king's presence, and was frequently of little importance even there; and the Königsburgs, as, for example, those established by Henry the Fowler and his son, while of great value as a protection against the Slavs and other marauders, were merely strongholds for the use of the localities, and not royal fortresses protecting industrial populations under the king's special favor. As Pirenne points out, the royal power was extremely weak in Germany, and the emperors were more frequently hostile than friendly to the burghers. From the beginning the emperors systematically favored the local princes against the towns; for they held their crown at the pleasure of the local princes. Not until the end of the Middle Ages did they assume the position taken by the French monarchs. ${ }^{x}$ Furthermore, the royal power was in no place able to give the burghers substantial aid in their struggles until the urban movement was well under way. In France the crown certainly had scarcely a shadow of authority until the reign of Louis le Gros (II08), while in England the commercial movement did not begin until some time after the Conquest. Whatever the ancient royal power might have done, it had largely passed away during the feudal period and could not assist the merchants against the seigneurs. The new royal power could develop only correlatively with the development of commerce, and therefore with the development of the towns which became commercial emporia; and had the royal power become established prior to the rise of the towns, it would not have helped the latter until they had helped themselves enough to become a factor in the political struggles of the time.

Other theories of the origin of the towns, such as the "freemark theory" of von Maurer, to which we have already taken exception, or the gild theory advanced by Wilda, need no consideration in this connection. In every theory we have noticed, some element of truth may be found. Historical facts can be cited to show that this town did spring up under a strong castle, that another had been established on the site of a great fair, that

Pirenne, Revue historique, LIII, 8I. 
still another had grown about an old city, and so on. But as explanations of the real origin of the towns, all of these are inadequate. While the urban constitutions were formed under the influence of these various forces, they originated in the economic causes which have been described above. ${ }^{1}$ The original town was simply the inclosed suburb or new town formed by the merchant immigrants, in which they protected themselves and governed themselves according to the needs of the situation. In the eleventh century these merchants were still considered strangers; but their example was contagious, and a greater and greater number of the ancient inhabitants of the surrounding country and of the old city-if the town grew up about one-sought to engage in commerce and industry. The clergy and the villeins alike joined the nucleus of traders that had been gathered, and tended to identify themselves with the interests of commerce rather than the interests of their own classes. Not until the twelfth century were efforts of any importance made to found merchant colonies by preconceived plan; and then the attempts were successful only when the locations were favorable.

Establishment of the urban constitutions.-The urban constitutions were in part the necessary consequence of the change in the status of the urban populations and in part the safeguards of the growing freedom acquired by the burghers through the working of economic forces. The chief feature of the town was its autonomy. It might be subject to the seigneur of the district to the extent of paying some kind of tribute to him; but its internal affairs had to be exclusively in the hands of the burghers. This autonomy was insisted on, not from any desire for freedom for its own sake, but because commercial interests could not flourish under the control of arbitrary and irrational seigneurial methods. The rising of the communes against seigneurial rule was spontaneous and universal. The eleventh and twelfth centuries were full of these uprisings. The feudal tolls were

I Les villes sont nées spontanément sous l'action des causes économiques qu'a suscitées en Europe la renaissance du commerce et de l'industrie. . . . . De lui même, en effet, le courant économique se porte vers ces endroits."-Pirenne, Revue historique, LVII, 68. 
intolerable, and were, of course, most burdensome in the neighborhood of the commercial centers. And the domanial customs governing the relations of persons and of property were so unsuited to a commercial age that urban laws and courts had to be substituted for them.

In return for the heavy feudal exactions, no services whatever were rendered by the lords. The roads were not kept in repair, and no protection was given to the merchants either in their towns or on the roads. The merchants of the towns had to form associations for the construction of public works and for selfprotection. These did not necessarily take the form of gilds, for there were communes where the gild was unknown-for example, Cambrai, Beauvais, Tournai. Nor, since the great works of Gross and Hegel, can it be maintained that the gild ever gave birth to the town. The urban community was usually ruled by an aristocracy composed of the leaders of the merchant gild or of the greater craft gilds, but these close corporations were a later development: they helped in developing, but did not originate, the towns. ${ }^{x}$ Nevertheless, the early merchants, like all other men who have been drawn together by common interests were forced to form some plan of co-operation. When traveling in caravans, they were obliged to maintain some discipline, and were naturally led to form a regular company with chiefs whose authority, though temporary, was absolute under certain conditions. The flotillas and fleets likewise had to be governed. The merchants who were given the lead under such circumstances naturally became the leaders when their communities arose in revolt against feudal exactions. At Cologne in ro74 the rebellion was provoked by the requisition of a merchant's boat for the use of the bishop. In Flanders the merchants arose in revolt against William of Normandy in 1127, because he had failed to keep his promise to suppress the tonnage duties.

Almost everywhere the lay towns had a more peaceful development than those under ecclesiastical lordship. This was partly

I Gross, Gild Merchant, I, chap. i. 
because the secular lords seldom resided in the cities. The greater part of the year was spent in traveling about their domains. But the ecclesiastical lords were always in the midst of the urban population, and when the merchant settlements began to grow, the bishop or the abbot could keep a strict watch upon them and prevent them from gradually gaining the power they coveted. Again, the ecclesiastical lords held theories drawn from the writings of the fathers, which led them to regard the feudal social organization as the ideal. Their administration had been uniformly excellent. They had treated their villeins with liberality and intelligence. But for the very reason that they had a higher idea of their mission and had gone about their task more seriously than the secular lords had done, they desired to maintain the system they had fostered. The new political program was incompatible with certain principles which the Church was not prepared to abandon. It could not renounce its tribunals, its rights of asylum, its juridical and financial systems. Nor did it seem desirable to change the paternal system to which the world had become accustomed and whose best features were so largely the result of the modifying influence of the Church. Therefore, the conflicts against ecclesiastical seigneurs were usually more violent than those against the less benevolent, but more careless, secular lords. The latter frequently allowed their power to slip away from them before they realized what was going on. Not paying much attention to the business management of their domains, they were likely to be satisfied to permit changes to take place, provided their accustomed incomes were not actually diminished. But the bishops and abbots watched every movement and sought to check the dangerous commercial tendencies. Even Cambrai, under its good bishops, had to resort to violence. In these struggles with their seigneurs the communes were everywhere successful. Mans (I072), Cambrai (I076), Beauvais (I099), set the example for the communes, and by the thirteenth century all had become free from the feudal yoke. The effort to maintain the domanial organization was everywhere futile, just as the attempts to withstand the movement toward disin- 
tegration had been unsuccessful in the previous epoch. Both revolutions corresponded to social and economic transformations more powerful than governments and traditions. The accomplished fact of urban independence had to be ratified-here under pressure of war and rebellion, there for payments of money, elsewhere because the seigneurs took account of the new situation. ${ }^{x}$

The communes in France were assisted in their struggle for independence by the growing royal power. For the same reason that the exactions of the seigneurs of the towns were intolerable, the tolls and duties on the rivers and roads became unbearable. The rivers were of greater importance than the roads, both on account of the greater security of that means of transportation and because of its greater cheapness. But from Paris to Rouen, from Orleans to Nantes, from Toulouse to Bordeaux, there were scores of river seigneurs who levied toll on all passing commerce. The same conditions prevailed, in a more aggravated form, along the land routes. The associations of merchants and the confederations of free communes treated with many of the seigneurs, and bargained for exemption from tolls in return for a lump sum. In France, Burgundy, Normandy, Flanders, and other important kingdoms and duchies, the royal or ducal power was likewise interested in getting control of the tolls, as well as in breaking the power of feudalism. In France the power of the Capetien kings was steadily gaining; the Duchy of Francia was being enlarged by the annexation of contiguous fiefs; and the new royal house was ambitious to carry out the theories of the monarchy and the central organization of the State that had always been held in some vague form. It was becoming more nearly possible to maintain a central government because of the settled condition of the country and because of the greater resources which the king could command.

The first movement in this direction was found in the great fiefs. The great feudatories intervened in the quarrels of their

× Hegel, Städte und Gilden der germanischen Völker im Mittelalter, II, 55 ff.; Pirenne Revue historique, LVII 304-7; Levasseur op. cit., I, 180, 181. 
vassals, suppressed brigandage, abolished some of the arbitrary tolls, and confirmed the charters which the seigneurs had been obliged to grant to the communes. Some of the great dukes and counts were more truly sovereigns than Philip I was in the royal domains. In the northern sections, where the industrial movement was most marked, this centralizing tendency was strongest. But by the beginning of the twelfth century the kings of France were in possession of rather wide dominions in a strategic position, which had been brought together by Philip $\mathrm{I} ;{ }^{\mathbf{I}}$ and Louis VI laid the real foundations of Capetien greatness by reducing the feudal castles on the Seine and the Oise, giving justice to the peasants and traders, granting charters to many communes, and, in general, establishing a real sovereignty within his own dominions. The same suppression of the outgrown powers of the baronage of their respective districts was accomplished by the other great feudatories. With these latter Louis had practically only international relations. But after the development of law and order in the great fiefs had everywhere raised the commercial communities and undermined feudal institutions, the overthrow of the Angevin power at Bouvines (1214) enabled Philip Augustus to extend the royal authority over the greater part of northern and central France; while the support given by that monarch to the Albigensian Crusade resulted in the addition of Languedoc and Provence to the royal dominions and their final assimilation into the national life.

The natural course for the king, as for the great feudatories, was to take the part of the merchants against the seigneurs. By this means the communes were assisted in obtaining autonomy, or in maintaining a position already gained; and-what was equally important - the merchants were relieved of the numerous exactions of the feudal lords and subjected to more moderate and more regular taxes imposed by the king. The towns on the royal manors were not so favored, for the kings had no desires to build up rival powers; but these towns received every advan-

I Luchaire, Histoire des institutions monarchiques de la France sous les premiers Capétiens, II, $246 \mathrm{ff}$. 
tage of the revolution that was going on elsewhere, save that of autonomy. Paris never had a communal charter; yet the burghers of Paris enjoyed very extensive privileges and became practically self-governing. Orleans was the only royal city to attempt to constitute itself a commune, and it was severely punished for the attempt.

The kings sought only political power and did not care to preserve serfdom, until, too late, they saw that complete industrial freedom tended toward a democracy that would be as inimical to royalty as the feudal aristocracy had been. The seigneurs likewise desired only political power, but their political authority was bound up with the control of their domains. Their economic lordship could easily be overthrown by the king, provided the burghers would transfer their political allegiance to him. This the townsmen were ever ready to do. There was no very strong desire for municipal liberty, provided the economic arrangements could be adapted to the needs of commerce without political independence. Self-government was only an expedient to which the merchants had been compelled to resort in order to free themselves from the sovereignty of lords who were unwilling to adapt their demands to the changed conditions. It is a historical fallacy to read back into the consciousness of the burghers who were struggling for the right of self-government the desire for independence for its own sake. The latter would come, if the commune could maintain its independence for some time; but in the beginning independence was desired for practical reasons only. The free communes of France made an economic gain, but maintained political equilibrium with difficulty; so that the royal power easily assumed control of the political functions. A wide-reaching state had many manifest advantages over a host of petty city republics. A liberal spirit was shown by the crown in all the regulations of the towns which were successively annexed to the royal dominions. Sometimes even the communes were respected. The charter of Rouen was sanctioned by an ordinance of 1278 , and in 1303 Philip le Bel confirmed the juridical rights of the consuls of Toulouse. By the time of Philip Augustus, 
the royal laws were administered under the supervision of royal baillis; and this check upon seigneurial laws and pretensions compensated the towns for the loss of complete autonomy. In matters purely municipal the towns were allowed great liberty. Only after the nobility had been made wholly subservient, did the kings attempt to suppress the expanding bourgeoisie. On the whole, we are to regard the French monarchy, not as inaugurating, but as helping on, the inevitable industrial development. Its power was due in part to the resources of the royal domains and their favorable location, in part to the sagacity of many of the Capetien kings, in part to the stupidity of most of the Plantagenets, but chiefly, we must believe, to the fact that it placed itself in line with the economic movement of the times and helped to break down a system that was no longer adapted to social needs. The economic movement preceded the political by many years. The resistance of the seigneurs represented the persistence of the old structure; the struggles of the merchants and the king, the attempt to secure a new adaptation.

In Germany the public power did not revive in time to be of importance in this development. There were no such rulers in Germany as the great feudatories in France. The petty princes were so engaged in political struggles with one another that they had little time to devote to the internal development of their dominions. They purchased the support of their vassals by helping them to resist the demands of the burghers; and the emperor, who never had the resources of a relatively strong royal domain to help him to establish himself, as was the case with the French king, was obliged to purchase the support of the princes by opposing the towns. The towns were thrown more entirely on their own resources. The Germanic hanse was necessary not only for the protection and furtherance of trade in foreign parts, but also to take the place to some extent of a national government. It was not merely the interdicts of kings that kept the French cities out of the league: the regulation of affairs in the whole region to which they belonged was in their interest. The German cities had to keep up a much more prolonged 
struggle against feudal exactions. With them the league took the place of the national power.

In England the towns arose more slowly and with less friction. There are evidences of a slight movement toward urban development before the Conquest. There were some eighty towns in existence when the Normans came; but the largest of these contained no more than seven or eight thousand inhabitants, and many of them were probably no more than episcopal cities. There are some indications of a movement toward urban constitutional development; ${ }^{\mathbf{x}}$ but most of the towns were mere hamlets under complete feudal domination, and none had yet secured autonomy. Such trade as then existed was centered in these little towns. London, Sandwich, and Dover carried on a trade with the Franks; Bristol and Chester were extensive slave markets; York, Lincoln, Norwich, and Ipswich had commercial relations with the Baltic regions, the Danes having established a flourishing trade with their home country. During the Saxon period, however, England was a country of manors, and scarcely the beginnings of commerce were found. Merchants were seldom mentioned in the laws, and scarcely existed as a separate class. The imports were all articles of luxury for the higher classes, such as silks, gold, gems, wine, oil, and glass; while the exports were exclusively raw materials, wool being the most important. The frequent mention of the Jews in the old accounts indicates that much of the trade must have been in the hands of that race.

The first effect of the Norman Conquest was the decrease of town populations, caused both by the destruction of war and by the policy of William to build castles to overawe the whole land. ${ }^{2}$ But the closer connection with Normandy and Flanders served to stimulate trade, and the greater security which prevailed after the Norman rule was established made possible greater internal prosperity. After the Conquest, Norman artisans were imported to provide for wants which the Saxon laborers could not satisfy. Most of the towns were on the royal domains. These readily

r Stubbs, Constitutional History, I, 93 ff.

2 Ashley, Economic History, I, chap. ii, passim. 
secured charters when they arose to importance. Others which belonged to the demesne of barons and abbots could gain their freedom only step by step. On the whole, however, the charters were gained much more peaceably than they were on the Continent. Many charters were granted during the reign of Henry I, freeing the burghers from the old customary duties in return for a fixed rent, and giving them the right to choose their own justices and to enact their own laws. Even during times that were unfavorable to trade, as when the nobles were waging war against one another during Stephen's reign and when they went under Richard I against the Saracens, the towns continued to advance; for though commerce might have its backsets at those times, the seigneurs were all the more willing to sell charters.

Until a comparatively late period, the English towns remained little more than trading-centers. Such manufacturing as went on within them was for the local market only. In the new division of labor which was being organized, England remained an agricultural country. The new commercial activity caused the decay of the self-sufficient manorial system, but the introduction of manufactures did not follow. The wealth of the English consisted, above all else, in their flocks of sheep; or, at least, wool was the chief surplus which could be exchanged for other commodities. The comparative peace established by the strong government of the Normans made sheep-farming more practicable than it was amidst the struggles of barons and sovereigns on the Continent. The magnificent natural pasturage of England and proximity to the regions where the textile arts were earliest and most successfully cultivated likewise had much to do with the development of the English wool industry. Later, when England had a virtual monopoly of the supply of raw wool, the ease with which the government could gather revenues from export duties on this commodity added a political reason for the encouragement of the exportation of wool. Not until the reign of Edward III did the manufacture of wool, except by the family for home consumption, begin to assume any importance whatever; and it was not until the Tudor period that English cloth 
could compete with the Flemish. Not only did the profitableness of the trade in raw wool stand in the way of a diversion of labor and capital to other fields; the English laborer seemed to to lack in inventiveness until he was re-enforced by Flemish immigrants. In addition to raw wool, lead and tin were important exports. The imports, except iron, were chiefly articles of luxury. But wool remained the chief article of export. Because of this fact, that English industry was still agricultural and extractive, the towns did not grow so rapidly as in those sections where manufacturing was carried on. The merchants remained merchants. Few important craftsmen arose; that is, few whose business gave them interests outside of their own communities. On that account the merchants remained a more compact body than they would have been, had they early come in conflict with strong bodies of craftsmen. Therefore the gilds merchant occupied an exceptionally strong position in England. By the close of the twelfth century these organizations were found in nearly all the important towns of England, while the craft gilds did not become numerous until a century later. By that time the merchant gilds had become strongly rooted, and the introduction of manufactures was so gradual that the craft gilds did not become strong enough to engage in serious conflict for the mastery of town governments and trade regulations. In Germany and the Netherlands the craftsmen were early able to contest the supremacy of the merchants.

England thus remained an agricultural country, but not in the sense that all Europe had been agricultural during the preceding centuries. A surplus was produced for export, and commercial towns naturally sprang up, just as was the case on the Continent; but manufacturing industries did not become important until the Tudor period, and then only as artisans were imported from the Continent. The old self-sufficiency was destroyed, but not to quite the same extent as elsewhere; for a country that continued to produce all of its raw materials depended but little upon any other country except for the articles consumed by the upper classes. Within the kingdom, however, the old 
local self-dependent community was broken up. The manor ceased to be a complete society, for its inhabitants exchanged the things which they could most advantageously produce for commodities which they had formerly been obliged to produce, but which could now be produced more economically elsewhere.

The essential feature of the town was, as we have seen, its autonomy. This autonomy was substituted for the old domanial control. Independence in the management of internal affairs having been secured, the towns could work out such form of government as was best adapted to their needs. Since the needs of commerce had freed the towns, the commercial class became the citizen class. Accustomed to co-operating in their struggles against the seigneur and when traveling in caravans, the merchants naturally formed a body of citizens who could conduct the municipal government. The merchant association did not govern the city, as some writers have assumed. The gilds had their officers and rules, but these were not directly transformed into urban magistrates and ordinances. They contributed to the public works of their town from their own treasuries, but their dues did not become the public taxes. The gilds were voluntary associations, while the commune was a political organization in which every individual had to be subject to the collective action. Within the gilds there frequently arose superior classes who practically controlled their organizations. Much more, then, might these same great merchants be expected to control the affairs of their commune. The merchant class naturally controlled the policy of the commercial towns, and the leaders in the gilds were uniformly the leaders in urban affairs; but this did not involve the blending of the two organizations. The commune included all persons within the town walls who would take the oath of loyalty, whether members of the merchant gild or not, and whether having a voice in public affairs or not. Finally, everybody had to become subject to the communal authority, it mattered not what his original status had been, under penalty of expulsion from the town. If the colony of merchants had been formed about an old city, there existed beside it a mixed 
population consisting of the clergy, sometimes a secular nobleman, soldiers, ministerials, and many classes of unfree persons. The lands within the city represented as many kinds of tenure as there were classes in the population. But in time the new activities transformed all classes of men and all tenures, producing a new unity.

The merchants, at first, though protected by their associations and by the jus mercatorium, so far as the latter had any force, might still be unfree and under domanial jurisdiction. Many of the traders, of course, got so far away from their old masters that the latter could no longer hold them, but many were under the technical jurisdiction of neighboring seigneurs. They were liable to forcible return to their seigneurs at any time and to reincorporation in the villages to which they belonged. Now all of these feudal claims, products of a purely agricultural civilization, were incompatible with the new economic activities and had to be abolished by argument or by force. There was scarcely an urban charter that did not stipulate that the servitude of the members of the commune to the seigneur should be abolished. From the twelfth century residence in a town for a year and a day assured exemption from any seigneurial claims whatever. This movement for personal liberty was necessitated by the requirements of the new life, and had nothing to do with conceptions of the dignity of humanity. With personal liberty for the inhabitants of the town came liberty of the soil of the town. The seigneurs frequently retained a nominal title to the urban land, but the rental was only nominal; and the land, practically unencumbered by any of these claims, could be freely transferred by the burgher. It thus became an important item of wealth and a collateral on which the merchant could raise capital for the extension of his operations. The free land, like the free man, necessarily fell under the jurisdiction of the urban tribunal.

Beyond these features of the urban constitutions, it is scarcely necessary for us to go in this inquiry. The development of these constitutions is a subject full of interest to the student of political institutions, but for our purposes it is only necessary to note the 
manner in which the political structure was determined by the industrial life. In the division of municipal powers, in the regulations of industry, in the imposition of taxes, in the special methods by which the town "peace" was maintained, the communal governments differed among themselves in almost every conceivable manner; but in securing independence of domanial rule and in making everything serve the ends of commerce, the constitutions of the communes were practically the same in all parts of Europe. ${ }^{x}$

The gilds and the status of the individual.-It was shown in the last chapter that the agricultural organization had brought about a change in the status of the laborer-that by the time the manorial system was fully developed slavery had disappeared and the servile populations had secured a virtual freedom within their industry. A full individuality was not attained because the individual functioned, not for European society as a whole, but for the small manorial group. The economic institution, the manor, mediated between the individual and society. The individual, while free within the manorial limitations, was still a serf. $^{2}$

Now, while the condition of serfdom might continue indefinitely in backward agricultural communities distant from the centers of industry, it was wholly incompatible with the life of the commercial communities and even of agricultural sections which had been disturbed by commerce. The important commercial activity of England was carried on by foreigners, and manufactures were very backward in that country; nevertheless, serfdom was breaking down in England even before the Black Death. The prosperous condition of English agriculture led to an increased demand for labor, and the exportation of wool brought a comparatively large amount of money into the country. The Black Death destroyed about half of the population, consequently doubling the per capita money circulation. Thus, it became easy for the villeins to commute their predial services

I Pirenne, Revue historique, LVII, 88-93.

-Vide supra, 181, I82. 
for money rates; and the lords were obliged to commute at the old valuation of such services, for otherwise the serfs who sought to make the change would simply join the large number of others who deserted the manors to which they belonged, and settled where conditions suited them. From the beginning of the urban movement there was a persistent struggle on the part of the burghers for freedom from all feudal obligations. From the twelfth century this freedom was generally guaranteed to anyone who resided in a town for a year and a day. This freedom from personal control was desired, not from any abstract love of liberty, but because it was absolutely necessary for the satisfactory performance of the new economic activities. Of course, after the economic changes had brought about these changes in the status of many of the villeins, others could see no reason why they too should not be relieved of their old burdens even though they continued to follow the old pursuits; hence doctrines of social equality began to appear. ${ }^{x}$ The feudal bonds were broken by the various associations which were formed by the merchants, including the communal organizations which, though of a political nature, existed for the furtherance of economic ends.

The formation of these various associations by merchants and artisans was natural and spontaneous. Men having common interests are bound, when thrown together, to form associations for mutual protection and the furtherance of common interests. When merchants began to travel from place to place in company, they naturally organized themselves for defense, joint bargaining, and internal order. When the traveling merchants habitually visited a certain place, they would naturally establish a depot, as, for example, the Steelyard in London, which had to be under the permanent control of some kind of an association. When large companies of merchants settled permanently in a given place, they were obliged to form an organization having wider powers than a mere association for the promo-

x Cf. Page, "The End of Villainage in England," Publications of the American Economic Association (Third Series), I, 358, 359. 
tion of commercial interests; but these communes were formed under the influence of the merchant associations and were adapted to commercial needs. Yet the formation of a political organization adapted to the new life did not do away with the voluntary associations. The immediate interests of commerce were still intrusted to the latter. Under the forms of gilds, hanses, brotherhoods, banquets, etc., ${ }^{x}$ the trading population found it possible to carry on an activity which was impossible for isolated individuals. Some of the associations which controlled commerce were craft gilds, as in Florence; some were companies which had been organized for protection along the routes and for collective bargaining with the seigneurs who levied tolls, as the Marchands de l'Eau of Paris; some were organized for collective bargaining and the control of retail trade, as the gilds merchant of England. In the first instance, the importance of the town grew out of the handicrafts which, starting in a humble way for the supply of a local demand, finally sent their wares into all parts of Europe. Usually such a town had several important trades, and the supervision of its commerce was assumed by a sort of federation of the several craft gilds. We must remember that the early craftsmen were merchants at well as manufacturers, displaying their wares on the counters of their own shops and at the weekly markets and the fairs. In the second instance, we find trade preceding manufactures. Here the wandering traders transformed their caravan organization into a merchant gild which continued to protect the traveling merchants from brigands and arbitrary seigneurs, and also promoted and controlled the commerce of their city. The third class of associations naturally arose in communities which carried on a local trade. Since the trade with distant places was largely in the hands of foreigners, the function of the native merchant was to gather up the products demanded by the foreign trader, to distri-

× Gilds were not found in southern Germany and in many French cities; but where they were lacking the necessities of trade compelled the merchants to form analogous, if looser, organizations to take their place. Cf. numerous authorities cited by Pirenne, Revue historique, LVII, $8 \mathrm{r}$. 
bute the foreign goods received in exchange for these, and to carry on the local trade which centered in his town.

The associations of this last class have received a greater emphasis than the others because of the attempt of a certain writer-to whom attention will be directed later-to trace a connection between the gild merchant and the craft gild and between the latter and the trade union. In reality, the English gild merchant had much less to do with the development of commercial institutions than the continental gilds had. In England, where the operations of the merchants were more restricted than elsewhere, because the foreign trade was in the hands of foreign merchants, the gild merchant had for its principal function collective purchase and sale in the interest of its members. ${ }^{x}$ The origin of these associations is lost in obscurity. It certainly antedated the Conquest in some cases. The merchant gild may have been a company of traveling merchants before the settlement in a town. It may have been organized for the sole purpose of conducting collective bargaining, after the merchants who had settled in a given place had secured their town charter. The latter was certainly the case in the later towns. Sometimes, at least, it included all of the inhabitants of the town. ${ }^{2}$ Where the gild was of this character, it could not have had much significance in the development of commerce, however valuable it may have been in securing favorable retail prices for the inhabitants. The later charters usually grant the towns the right to have gilds merchant along with the other privileges which were supposed to be essential to urban life; but the fact that the gild merchants are frequently the product of royal grants does not prove that they did not, in the beginning, antedate the organization of towns. Even after the gilds became creatures of the law and seemed most important as regulators of the local markets, they continued to serve commerce by securing its exemption from petty burdens in all parts of the kingdom. It is a mistake to take the view of

× For numerous instances of combined purchase, vide Gross, Gild Merchant, II, $65,67,122,1_{23}, 1_{33}, x_{5}$, etc., especially p. 67 in case of the Dublin gild.

2 Ibid., I, I07. 
Gross, that the gild merchant was essentially a narrow and exclusive association which simply "shackled free commercial intercourse." Free commercial intercourse was an impossibility until the end of the Middle Ages; and at the beginning of the development of any commercial movement there could have been no commercial intercourse at all, had it not been for these commercial associations. Gross forms his judgment of the gild when it had reached its aristocratic form, and reads this back into the earlier period when it had a real function. The important work of the gild merchant had been completed by the time it had established itself as an exclusive association. As time went on, the gild became less important, until, by the fifteenth century, it had disappeared in many places, in others had been merged into a company of merchant adventurers, while in general it "coalesced with the town organization so completely that it became a mere term to designate the privileges of the whole body of burgesses."2

The merchant associations of Flanders and northern France played a much more important part than those of England, because their members had so much wider commercial interests. Some of these associations had a very early origin. The Marchands de l'Eau of Paris may have been the direct descendants of the Nautes of Roman times. Louis VI, in II2I, granted them certain privileges as a company already ancient. ${ }^{3}$ Their earlier activity had to do with the provisioning of Paris from distant fields along the Seine, but they became important on account of their general commercial activity. The gild of St. Omer was officially recognized by Wulfric Rabel as early as 1072.4 This would push the beginnings of this association back to the tenth century. The few cases of this sort of which records are preserved are very good evidence of the early origin of others where conditions were similar. Throughout Flanders, which had become

I Ibid., chap. iii, especially p. 50 .

2 Seligman, "Two Chapters on the Mediæval Guilds of England," Publications of the American Economic Association, II, 425.

3 Levasseur, op. cit., I, 192.

4 Gross, op. cit., I, $290 \mathrm{ff}$. 
the greatest industrial and commercial region of northern Europe, and in Normandy, where commerce had become important by the time of the conquest of England, the commercial interests of the towns and the protection of trade on land and water were in the hands of these voluntary associations. By the thirteenth century, they had become so important that they engaged in bitter conflicts as rivals, or, uniting in the Hanse of London, began to threaten to break away from all political allegiance.

The Italian merchant associations will receive attention in connection with our consideration of the Italian cities. These usually originated as artisans' gilds, and as the industries became more extensive the more important members ceased to ply their crafts and became virtual entrepreneurs, while remaining the ruling members of the craft gilds. A federation of the greater gilds, each of which simply voiced the will of the merchants dealing in its products, served as the gild merchant of the city.

While purely voluntary associations, the early merchant gilds sought to induce all merchants having common interests to become members; and, on the other hand, the necessities of commerce were such that to refuse to enter was to cut oneself off from the only means of protection and to drop into a position of manifest inferiority. ${ }^{x} \quad$ Consequently all merchants of importance became members of the associations. Those who for any reason attempted to act as independent individuals could not survive. But the aristocratization of the associations was as natural as their free beginning had been. When they had become privileged companies, they naturally limited their membership and exploited other classes of the community. The advantages of limited membership becoming apparent, the merchants maintained their organizations after the establishment of order and the development of communal government had rendered them unnecessary. The associations of merchants frequenting the Seine and the Loire lost their raison d'être after the conquests of Philip Augustus had consolidated the sovereignty of the regions in which they operated. The rival associations x Pirenne, Revue historique, LVII, 82, 83. 
of the Loire were blended by the end of the thirteenth century; but the rivalry between the Parisian and Rouenese hanses could not be overcome in the same way. The hanse of Rouen was suppressed by an ordinance of Philip IV in I292. It revived again, but was finally abolished by Louis $X$ in 1315 . The misfortunes of the Rouenese were due to the influence and power of the Parisian association, and the latter abused its triumph. The latter was overruled in its pretensions by the Parliament of I385, and practically abolished by Louis XI in $1461{ }^{x}$ This greatest of French merchant gilds thus maintained its existence for fully two centuries after it had ceased to perform any useful social service. Its members simply enjoyed an important monopoly. By the thirteenth century the gild of St. Omer, one of the most famous of the Flemish associations, had become a syndicate of capitalists, not even comprising all the great merchants of the city, but only those who traded with England. ${ }^{2}$ It was the same in the other Flemish cities, whose gilds, federated under the name of the Hanse of London, kept a monoply of the commerce with England. In England the gild merchant was a useful institution so long as all members of the merchant community were included in its membership; but in time it became exclusive, securing for its limited membership a monoply of the right of combined purchasing and of retailing of foreign products in its town. ${ }^{3}$ By the time of Edward III the gilds merchant were becoming aristocratic and oppressive. In Florence the federation of greater gilds having to do with foreign commerce soon became aristocratic, practically ignoring the interests of all other trades and even of their own artisans. As a rule, neither kings nor sovereign dukes and counts thought of destroying corporations which had now become ancient and powerful, provided they would recognize the sovereign power. In return for loyalty the associations received legal sanction for their monopolistic policy. "It was thus that the Hanse of Rouen, the Marchandise de l'Eau of Paris, the Jurade of Bordeaux, the Batellerie

I Pigeonneau, op. cit., I, I76-80; Levasseur, op. cit., I, 285-96.

2 Giry, St. Omer, 4I3; Pirenne, Revue historique, LVII, 84.

3 Gross, op. cit., I, 42. 
of Orleans, Saumur, Angers, and Nantes, after having constituted themselves at first for defense and by private initiative only were transformed into monopolies and privileged companies officially recognized."I It was the same story everywhere. The Marchandise de l'Eau of Paris and Rouen, the gilds merchant of England, the Gewandschneider of Magdeburg and Brunswick, the Seven Greater Gilds of Florence, alike exercised powers, originally acquired in genuine social service, for the mere aggrandizement of their aristocratic members.

Of no less importance in the development of modern industry were the craft gilds. The place of these organizations has been rendered somewhat obscure by the hasty conclusions of Bren$\operatorname{tano}^{2}$ and others who have been more interested in the form in which the craft gilds first appeared than in the function they performed. It has been attempted to show that the oppression of the craftsmen by the wealthy members of the merchant associations rendered it necessary for the former to organize gilds of their own for self-protection. But such a conflict was not universal, to say the least, and in England, where the craft gilds had their largest development, it did not take place at all. ${ }^{3}$ There is no evidence that these associations were formed by lower, semiservile classes of workmen or by men who had been excluded from the merchant gilds because they did not belong to the new aristocracy. In some towns there were craft gilds, but no gilds merchant at all; in others the former came into existence before the latter; in still others the craft gilds and the merchant gilds

\section{Pigeonneau, op. cit., I, r77.}

2 First given in his essay On the History and Development of Gilds and the Origin of Trade-Unions, written in 1870 as an introduction to the collection of gild-regulations compiled by Toulmin-Smith. This was followed by a more mature work, Arbeitergilden der Gegenwart. Brentano's position was undermined by Ochenkowski (Englands wirtschaftliche Entwickelung am Ausgange des Mittelalters), and finally overthrown by Gross (The Gild Merchant), as Brentano himself admits ("Entwicklung und Geist der englischen Arbeiterorganisationen," Archiv für soziale Gesetzgebung und Statistik, VIII, 79, 80). Seligman's essay, above cited, gives the best brief discussion of the question.

3 Ochenkowski, op. cit., $55-58$. 
arose at the same time. ${ }^{\mathrm{x}}$ We have no records of the expulsion of the craftsmen from the merchant association. On the other hand, we find numerous instances where men held membership in both classes of associations. ${ }^{2}$ Indeed, there was every reason why this simultaneous membership should be quite common. If the association had been formed primarily by traders, some of these traders were pretty sure, in time, to find it profitable to produce some of the goods handled by them. They would remain merchants, for the early manufacturer usually disposed of his own product. His continued interest in matters of trade would keep him in the merchant association; but his interest in the orderly conduct and protection of his special business would lead him to associate with others who had similar interests in the organization of a craft gild. If, on the other hand, the trader had been first a manufacturer of wares which he sold over his counter and at the fairs, the expansion of his business would render it necessary for him to unite with other traders, in whatsoever commodities, who belonged in the same community and frequented the same routes. Otherwise, he would not have enjoyed the privileges of combined purchase at home or of protection against robbers and feudal exactions abroad. Without such protection he could not have continued long in business. So we find merchant associations of both sorts. In neither case was it unnatural for a man to belong to a merchant and a craft gild at the same time. In all probability most persons who were engaged in trade and industry belonged to both. The growing division of labor resulted in the separation of certain of the craftsmen from the merchant associations; for many of them came to be solely manufacturers, disposing of their products to men who were solely merchants, or who, still craftsmen, had to do with but one, usually the final, of many processes through which the commodity had to pass, and who either took the unfinished product from allied crafts or furnished the materials on which men in allied crafts worked.

S Seligman, op. cit., 436, 437.

2 Ibid., $437,438$. 
Thus, when certain members of a merchant association became wholly absorbed by industry and no longer sold their own product, they ceased to take an interest in the affairs of the gild merchant and retired of their own accord. ${ }^{x}$ When the merchant gild became aristocratic and came to control the policy of the city in the interest of the trade in which it was engaged, as was the case in Florence and most of the Hanseatic cities, the crafts which supplied the purely local demands and the merchants whose trade was not fostered naturally felt some resentment. The conflicts between the merchant and craft gilds was caused by this conflict of interests, rather than the overbearing conduct of the great merchants toward the craftsmen who worked for them.

The best view of the origin of the craft gilds seems to be that taken in this essay concerning the origin of various other associations, namely, that common pursuits and common economic conditions will cause the formation of groups having common characteristics, whatever may have been the starting-point from which the organization began. It can not be proved that any of the craft gilds were the direct descendants of the Roman artisans' colleges. Since the Roman collegia were little more than organs of society by which the laborers could be controlled and since mediæval society was incapable of controlling industry, it is $a$ priori probable that these associations which existed primarily to promote the welfare of the workmen ${ }^{2}$ had an origin as independent of the Roman college as it was of the Egyptian labor organization. Yet in communities where bodies of artisans were carried over from Roman times, associations sometimes sprang up at such an early date that the new gild must have been formed by men who were not wholly ignorant of the Roman organizations. The Altino Chronicle proves that well-defined gilds of ministeria existed in Venice as far back as the ninth century. ${ }^{3}$ Possibly the Parisian hanse was originally a Roman collegium

× Pirenne, Revue historique, LVII, 84.

2 Cf. Levasseur, op. cit., I, I95.

3 Villari, The Two First Centuries of Florentine History, I, 127, 128. 
of boatmen on the Seine. Yet, even in such cases, the association underwent such a transformation that we may conclude that the craft gild had an independent origin.

Wherever artisan populations were gathered together artisan associations were bound to spring up, especially since all kinds of gilds were being formed for mutual assistance and protection. The prosperity of agriculture led to increased wants on the part of the wealthy proprietors, and these in turn resulted in an increased number of workmen in the manor. Some of the English manorrolls contain long lists of artisans. In some cases special officials were necessary to supervise these new workmen who were drawn from the villein class and worked in the manorial village. There is no evidence that any of these groups of village artisans formed combinations. ${ }^{x}$ Indeed, the character of the manorial organization was such that a craft gild would not have been possible in a village. In the towns, on the other hand, the organizations became practically universal, and their members were always divorced from every form of seigneurial connection. But the gilds were not the creation of the towns, as some writers intimate. ${ }^{2}$ They were usually found only in the towns, for only there could the necessary commercial facilities and security from feudal exactions be obtained; but some crafts, as the masons, who were extensively engaged in castle and church building outside of the towns, were organized without any reference to municipal authority. ${ }^{3}$ The gilds sprang up as spontaneously as the merchant associations. The individual could not stand alone, and did not think of standing alone. The guilds were voluntary associations, but all artisans felt constrained to enter them, for only thus could they pursue their calling in security. After the gilds were established and the methods of industry pretty well worked out, the towns could use the organizations as police agents and inspectors of the goods in the interest of the consumer; and even went so far as to compel workmen to become members of gilds.

I Seligman, op. cit., 432, 433.

2 Ibid., 450-57.

3 Cunningham, Western Civilization, II, 98, note. 
Some of these craft gilds must have had a very early origin. They were found in all parts of western Europe in the twelfth century. Weavers' gilds were formed in England soon after the Conquest. Hence, it may be inferred that they existed among the Normans and Flemings at an earlier date, for the English craftsmen were immigrants. A charter of II 34 mentions the corporation of Paris butchers as already ancient.

There were weavers' gilds in Marlborough, Beverley, and Oxford, as well as in London in the time of Henry I, and there was a similar institution among the cordwainers of Rouen, the tanners of Ghent, and the drapers of Valenciennes. Though these are the earliest recorded instances, it is highly probable that some similar bodies were of very long standing in certain continental cities. We have an account of the crafts of Paris in the thirteenth century, and when we see how largely manufacturing was developed in that city and at that date, and how completely it was organized, we can hardly suppose that the industrial associations were all of very recent growth. ${ }^{x}$

At first, as we have seen, the relations between the traders and the producers of the towns was very close, if, indeed, the same persons did not perform both functions. After the commerce in important commodities passed into the hands of great merchants, these remained members of the same gilds which included likewise the humblest craftsmen. Gradually, however, the trading and the producing classes became differentiated from each other. For example, so long as the Italian merchants handled the greater part of the product of the textile industries of northern Europe, the local traders had so limited a sphere of operations that they remained predominatingly craftsmen; but after the Italian influence began to wane and the commerce of the northern towns began to expand to large proportions, certain men connected with the industry became simply cloth-dealers. ${ }^{2}$ These naturally came to occupy the most advantageous position in the industry and were able to assume the rôle of capitalists, employing the craftsmen as wage-earners or distributing to them the raw materials on which they worked. 3 It was long before

I Cunningham, op. cit., 95, 96 .

2 Ashley, "The Early History of the English Woollen Industry," Publications of the American Economic Association, II, 355, 356.

3 Pirenne, Revue historique, LVII, 85, 86. 
capital played a very important part; but the gilds which dealt in the finished product tended to become oligarchical associations which controlled the trade policy of the towns and united together in the Hanse of London. When the other gilds sought to protect their interests, they were often treated most harshly by the wealthy merchants who desired to control the entire industry of their towns. Where, as in England, industry developed slowly and where the craft gilds were sometimes differentiated from the traders' associations, the craft gilds were left undisturbed by local antagonisms until they had gained strength. As business increased and the craftsmen desired to dispense with the privileged intermediaries and to engage directly in retail trade, friction arose between the craft and merchant gilds. ${ }^{1}$ But this friction was not so serious as that on the Continent between the classes interested in general trade and those interested in local trade.

The craft gilds always desired two things: the control of the technique and the control of the product. The latter consisted chiefly in regulations concerning the quality of the goods produced by the members. This regard for quality was so manifestly in the interest of the consumer that some writers have supposed that the gilds could never have made their regulations from self-interest, but must have been required by the municipal or central power to act as inspectors. But we must remember that it may be to the interest of the whole industry to have honest goods produced, while the individual producer may secure an extraordinary profit by selling adulterated goods or giving short measure. When prices are fixed with reference to honest goods, the man who can sell dishonest goods at the prevailing price profits by the general reputation which honest men have won for the goods in which he deals-until he has ruined his own market. There were two reasons why the individual should be prevented from profiting by departures from the recognized standards of his craft. In the first place, his

x Ashley, "Beginnings of Town Life," Quarterly Journal of Economics, X, 404, 405 . 
fellow-craftsmen would not tolerate such competition. Competition, at least within a local area, was not tolerated during the Middle Ages. The "just price" could be charged; no more, no less. Every dealer was to have the trade which his own industry secured, and to receive the reward which that volume of trade could bring at the customary prices. His fellow-craftsmen would not tolerate a cut in prices which might increase the volume of his business; nor would they permit a departure from the accepted standards which might increase his profits at the established prices. This rule of custom was characteristic of the whole period from the establishment of the mediæval economy until the Renaissance. The inspection under gild rules would prevent improvements as well as deterioration. Changes could take place gradually, but the tendency was to resist them. If new departures were to be made, new associations had to be formed to support them. In the second place, the inspection was considered necessary to prevent unscrupulous workmen from putting out goods that would ruin the reputation of the trade or the town. The profits which the single unscrupulous producer might realize before he drove away his own customers might compensate him for the loss of business that would follow; but the whole craft or the whole community could not thus profit. So the craft, in the interest of maintaining its own reputation, made and enforced rules against dishonest workmanship and short measure; and, later, when the whole community came to be dominated by commercial interests and to appreciate the social importance of all its industries, the gilds were authorized, or even required, to see that all goods were properly inspected, and craftsmen were forbidden to ply their trades at all unless they identified themselves with their proper gilds. Competition, which was forbidden within small areas, was quite keen in the wider markets; and the industry of a given locality might be ruined by selling goods below the standard for which the place had become noted.

This seems to be a rational explanation of the gild regulations concerning the quality of the goods produced by the craftsmen 
and of the municipal laws which sanctioned or required the inspection. It was entirely to the interest of the whole craft to prevent what an individual might find profitable. It likewise became of importance to the towns to maintain the reputation of their crafts. The gilds became useful agents of the towns in the enforcement of certain important features of municipal policy; but this does not mean that they were not a natural development of the economic activities themselves. The towns simply took advantage of these institutions, co-operating with them in the enforcement of a policy in which the interests of the community and those of the craft coincided. Individuals were compelled to join the gilds, but there was no compulsory formation of the gilds themselves. All craftsmen were compelled to conform to gild regulations, but the regulations were the work of the gilds and were not imposed upon them by municipal authority. The interest of both gilds and towns was in the prosperity of trade, not in the welfare of consumers, though it may be assumed that the towns were not altogether unmindful of the welfare of their own citizens.

The acceptance of gild regulations by the cities and the requirement that all craftsmen must be members of gilds marks the triumph of these organizations. They also mark the beginning of the time when the gilds were no longer so necessary as during their struggles, and when they might do industry more harm than good. Starting as purely voluntary associations into which any capable workmen could enter, with regulations that were intended simply to promote the general interests of the crafts, they tended to become close corporations with restrictive apprenticeship rules and to abuse their supervisory power by preventing progress. Rules limiting the number of apprentices and journeymen to be employed by one master and determining the duration of apprenticeship had as their end the monopoly control of the technique of the industry. So long as these rules could be enforced, the gilds were safe; but when the technique became less of a "mystery," their position became insecure and they sought to strengthen it by violent methods or by securing legislation to 
enforce their rules. Such efforts were a confession that the technique was already becoming common property. The regulations tended to be directed toward the preservation of a status quo, rather than the protection of the consumer from incapable or unscrupulous producers and the maintenance of the good name of the trade. Since economic conditions did not change rapidly for some time, this continuance of gild life did no great harm until the period immediately preceding the Industrial Revolution. But the gild, as an institution which effected the necessary mediation between the individual and society, had done its work and was now really obstructing the free functioning of the whole economic society through the individual.

During the commercial period which we are now discussing the feudal character of society was not lost, although some feudal institutions which were adapted only to the agricultural age had to be modified or destroyed wherever commerce became important. The towns demanded a certain independence, but it was simply independence of manorial rules. There was no objection to the recognition of a feudal superior and the payment of reasonable tribute, provided the internal economy of the town was free from his interference and commerce was not subjected to undue burdens. Within the towns we find the individual subject to general municipal law in many of his activities, but his economic activities were subject to the control of his gild. Thus the agricultural hierarchy of duke, lord, manor, individual, was replaced by a commercial hierarchy of duke or king, commune, gild, individual. Under the former régime, the individual was bound to remain under the jurisdiction of the lord, but his economic activities were free from all control except that of manorial custom; under the latter, the individual was subject to general municipal regulations, but his economic life was practically free from all control except that of his gild. The manor had a territorial definiteness that was impossible in the case of the gild, but each gild had its quarter in the town practically under its own control. A mixed relationship seems to enter where the same individual was a member of the craft gild and a merchant association, but 
here each sphere of activity was pretty definitely separated from the other; and cases are not altogether unknown, in later times at least, where the same indvidual worked tenures on two manors.

There were two reasons for this parallelism. First, the feudal structure naturally tended to persist. The mediæval territorial system was not done away when the towns were carved out of it. It was taken as a matter of course that the hierarchical system of allegiance and control should be applied wherever men lived in communities. In the second place, the character of commerce rendered it impossible for the individual to carry on his business alone. No single individual could produce enough to enable him to come into direct and individual relations with distant markets, nor did any individual find it possible, in the absence of adequate protection by public law, to carry on his operations without the support of his fellow-tradesmen.

Now the office of both merchant and craft gilds was to secure for the individual a freedom within his calling. The individual exists in so far as the social values of his actions are present in his consciousness. During the whole mediæval period, as we have seen, the individual was too feeble and his activity too resticted to permit of such a recognition except in an emotional way. The gap between this ideal valuation and the real conditions was bridged by the magic of the Church. But in the course of the industrial development this emotional consciousness of social relationships was being supplemented or replaced by the realization of actual organic relationships in the daily activity of the individual. Yet the value of this activity of the individual was not at first consciously realized, and there was therefore no true recognition of individuality. But the individual was carrying on activities which were outside of the political organization of society, and he was therefore free in a sense in which the ancient artisan never was. Yet he could not stand alone in his industrial activity, but had to be supported and controlled by his gild. The gild was free in the control of its own technique, but the individual was not. There could be no political control, no system of slavery, but there had to be gild management. The modern 
trade union is an association of individuals who constitute themselves an association because they feel their own relationship to their employers and to society. The gild was the spontaneous aggregation of individuals who had been drawn out of the old order and who found themselves pursuing common activities. Into this institution men were born, or adopted, or coerced, as into a primitive tribe. Individuality was growing all the while, but the individual was supported by this institution and by it directed in the performance of his duties. There was no individual who, feeling that he expressed certain social values, joined with others of the same sort to realize them more fully. Just as the agricultural slave became a serf when the control of the technique of agriculture passed over to the agriculturists, themselves organized as manorial groups; so the serf became a freeman when the control of the technique of the industrial arts was fully vested in the artisans themselves, organized as gilds. But this freedom was not yet complete. The old feudal bonds had to be broken, but the gild took the place of the manor; and up to the time of the Reformation the control of the individual's life had to be in the hands of an outside authority-in this case the institution of the gild-which mediated between the indvidual and the world-wide society.

On the other hand, the product of industry was, qualitatively at least, becoming more and more under the control of every individual, because of the change from the commerce of luxuries to one of necessaries and comforts of endless variety. Standards of comfort were developed which the individual was able to reach through the control of his technique secured by his gild. These standards being capable of gradual and indefinite expansion, the increasing prosperity of the merchant or artisan led to better and better living. A pecuniary emulation was set up which did much to develop the sense of individuality. But here also the gild would interfere-co-operating with the Church and public opinion-to determine what was fitting for the individual's station in life and in harmony with the economic interests of the community. Thus, while the individual was coming more and more 
to function for the whole European society, while the values of the whole society were more and more placed at his disposal, while he was securing control of both the technique and the product of industry, the consciousness of these facts had not yet fully come to him. The gild, representing his industry, was still his mediator, as the Church had been when his social consciousness was wholly emotional. But the community was constituted an organic whole through commercial interdependence, and the individual was practically an organ of that whole society. A further development was to bring him to a consciousness of the social values of his activity.

\section{THE SOUTHERN CITIES}

In the above discussion of urban development the southern cities have been ignored or treated as lying outside of the European social movements. They can not, however, be ignored, for their influence in European commercial development was of wide-reaching significance. Neither can they be regarded as lying outside of Europe, for they were not only heirs of the same past that so greatly influenced the rest of Europe, but they were likewise overwhelmed by the barbarian invasions. Nevertheless, these communities stand unique in the commercial development of Europe. The inhabitants themselves were more nearly lineally descended from the old populations than was the case anywhere in the North. The barbarians who invaded Italy were less numerous than those who settled in other parts of the Empire, and the industrial populations of the miserable towns which survived the first wars were left to themselves. Some of the cities of southern Italy never completely lost their old civic life. New cities also sprang up in Italy, occupying almost impregnable positions, to which many Italians fled from Goth, Hun, and Lombard. What was true of Italy was true in a lesser degree of southern Gaul.

The cities of southern France.-Of the French cities, Marseilles was by far the most important, though Narbonne, Toulon, Arles, Toulouse, Bordeaux, and other ancient Roman cities were 
also important commercial and political communities; while Montpellier, a new city founded during the Saracen invasions and situated at some distance from the sea, became a great emporium about the middle of the twelfth century, and Aigues-Mortes, a city developed from a mere village by Saint Louis soon after the conquest of lower Languedoc by the French kings, seemed at one time likely to outstrip all others in commercial importance.

These cities were virtual republics. Some, like Marseilles and Arles, were actual republics, independent of the kingdom of France and of the county of Provence, and only nominally recognizing the emperors. Others, as Toulouse, though owing allegiance to a seigneur, were autonomous. The authority of the southern counts was very light, indeed, and the bourgeoisie early took rank but little below the nobility. At the beginning of the eleventh century Arles and Marseilles alone possessed a maritime power comparable with that of the Italian cities. At that time the Greeks still had a counting-house at Arles-indicating that some communication with the East had been maintained. At the beginning of the crusading movements Marseilles was already building up a considerable commerce and was in a position to engage in the business of carrying the pilgrims of the Second Crusade. The transportation of pilgrims and crusaders was in the hands of private merchants, but the arrangements for transportation were made with the city authorities, and rules were made for the government of the fleets. The crusaders greatly advanced the interests of all maritime cities of the South. In III7 Marseilles obtained exemptions and special privileges in the Christian kingdom of Palestine. Commercial relations were developed with all important Mediterranean ports. The wools of southern France and the cloth of Burgundy and FrancheComté were sent to Italy; the metals, wines, oil, and pastel of Languedoc and Provence and the soaps manufactured at Marseilles were exported to Syria, Egypt, Tunis, and Ceuta; an extensive commerce was carried on with the Moorish cities of Spain. Vessels returned laden with the silks, tapestries, spices, and perfumes of the Orient, the sugars of Spain, the skins and 
wools of Morocco, the fine cloth of Florence and Milan, the cereals of Catalonia and Sicily, and the cottonades of Alexandria. Consuls were appointed for all important points at which trade was carried on, and an extensive commercial code was perfected by 1253 . The burghers became wealthy and powerful, and conducted foreign affairs with success.

Marseilles, like the other cities of the region, was commercial rather than industrial. These places never became great manufacturing centers like the Italian republics and the cities of the North. They served rather as links between the Italian and the Baltic and Flemish cities than as distinct contributors to the movement we are tracing. They also had both the strength and weakness characteristic of communities which depended largely upon a trade in luxuries-but these may better be considered in connection with the Italian cities. ${ }^{x}$

Amalfi.-Of the Italian cities there were three general classes, of which Amalfi, Venice, and Florence may be taken as types. Amalfi represents the survival of the Greek city, a mere carryingover of the methods of Greek commerce to Italy; Venice represents the new city clinging to the past and holding itself aloof from the developments of barbarian society except as it could trade with that society. Florence represents the new city springing out of the midst of the disorders of barbarian society and the agricultural stage of mediæval civilization.

Amalfi had always been a Greek city, and, after the fall of the Western Empire and the departure of the exarch from Ravenna, remained under the government of a duke and the patrician of Sicily, both of whom were appointed by the Byzantine emperor until the tenth century. The city, like all others of the Empire, had been modeled after Rome or had preserved equally ancient and republican institutions, and during the period of general disintegration continued to elect magistrates and to levy taxes for the maintenance of the public welfare. The two petty maritime cities, Naples and Amalfi, were practically beyond the reach

× Gebhart, Les origines de la renaissance en Italie, 4, 5; Pigeonneau, op. cit., I, I35-5I; Levasseur, op. cit., I, 347-49. 
of the barbarians. Amalfi, built on a mountain in the midst of the water and connected with the mainland by a narrow tongue of lowland, was easily fortified and rendered impregnable. The citizens formed a militia and submitted to rigid discipline under their elected captains. For five centuries they successfully contended with the Lombards of Benevento. The Greek republics of this coast and the Greek Empire were the only Christian powers possessing navies. Like the ancient Phœnicians, the Amalfitans could never be conquered by land forces so long as they maintained their sea power. They were able also to beat off the Saracens who attacked them from the sea.

The Amalfitan vessels poured the wealth of the Orient into the city. The products brought from the East were exclusively luxuries which were exchanged for the necessaries of life with the Italian and Provençal peoples. Their trade became very extensive and the profits were large. Amalfitan shipping interests constantly expanded, and Amalfitan maritime regulations, based on the laws of the Rhodians, became the basis of the later commercial jurisprudence of the sea. When the land route to Constantinople was cut off by the Hungarians, the Amalfitans and their neighbors controlled the only means of communication with the East.

And yet these maritime cities of the extreme South never became a part of Europe proper. They were identified with the old order so entirely that their only function was to pass over some of the wealth of the old world to the barbarians whom they exploited. They never engaged in manufactures, but were content simply to bring some of the luxuries of the Orient into Europe. Had they not been cut off by political disasters, they must nevertheless have seen their glory pass away after the re-establishment of a normal commerce. The ruin of Amalfi and her neighbors was brought about through their dealings with the Normans under Guiscard, who had secured control of Benevento and Sicily. Amidst dynastic difficulties Naples and Amalfi became pitted against each other. The former called in the new maritime power, Pisa, which finally completely ruined Amalfi. Naples under 
Roger of Sicily lost her liberty, and-chiefly on account of the falsification of her money-soon lost her commerce also. By the middle of the twclfth century all of the Greek maritime cities of Italy had dropped from history. ${ }^{x}$

Venice.-The history of Venice is much more instructive than that of the Greek cities. The city was established on its islands by the inhabitants of the mainland who had fled from Attila, the Hun. The islands were not capable of high cultivation, and the people were driven to the development of the salt industry, fisheries, and commerce. Completely protected from the barbarians, since the latter had no vessels, and even protected from maritime powers by the complex system of channels through which the city had to be approached, the Venetians were able to enjoy a freedom from external interference unknown to any other people of Europe.

The migration from Aquileia took place in 452. A letter of Cassiodorus, prætorian prefect of Theodoric, written to the Venetian tribunes in 523 , indicates that the city was already of commercial and maritime importance. By the eighth century the Venetians were in communication with France, Asia Minor, and Egypt. By the tenth century they had begun to establish colonies at points of advantage in the various countries with which they traded. Trouble with the Slavonian pirates of Dalmatia began in the sixth century, and war was carried on at intervals until the end of the tenth century, when the greater part of the Dalmatian coast was permanently annexed by Venice. From this time the commercial greatness of Venice was assured. Consuls were sent to all the Italian cities with which alliance had been made against the pirates; closer relations were established with the Mohammedans of Syria, Egypt, and North Africa, and with the rulers of Persia and the Crimea; the "Flanders Galleys" made annual visits to the ports of Spain, France, and England, going as far as Bruges; other fleets visited the ports of the Mediterranean and the Black Sea.

Like all other Mediterranean cities, Venice profited greatly by

s Sismondi, op. cit., I, I65-218. 
the Crusades. Perhaps the greatest profit was reaped from the Fourth Crusade (I203-4). When the French crusaders asked Venice to carry them to Palestine, the republic demanded their help against its enemies. The pirates of Zama were uprooted, and then Constantinople was taken. Venice took three-eighths of the conquered Byzantine territory and the French took the imperial crown. Thus the profitable Venetian trade with Saladin's subjects was not interrupted, the enmity of the republic toward Byzantium was gratified, and many attractive spots in Greece and the islands of the Egean were secured. "The real result of the Fourth Crusade was a great intermingling of populations in the whole country around the eastern end of the Mediterranean, and out of this came a vast impulse to all the activities of European life."

Unlike Amalfi, Venice became a manufacturing as well as a commercial city. Amalfi seems to have done no more than transfer products from one section to another. The inhabitants kept up their Grecian tastes, and, in so far as necessary industries were carried on-for example, the building trades-simply reproduced the methods employed in the eastern cities. Now the Venetians were equally eastern in their tastes and received their patterns from Constantinople, but they early began to manufacture for themselves and their customers those luxuries of which they learned in the East. In this they resembled the Phœnicians who began by carrying the products of Egypt and Assyria to Europe, but finally themselves manufactured goods which were better adapted to the demand they supplied. Naturally the trades first established were those which had to do with the bulkier commodities and those not transportable. Eastern workmanship was always taken as the standard, at least until new methods were developed. In 827, when the church of San Zaccaria was restored, an architect and a body of workmen were imported from Constantinople. The church of St. Mark's (IO7I) is wholly Byzantine in architecture. Gregorio, a priest from Constantinople, introduced the manufacture of organs

I Emerton, Mediaval Europe, 379-83. 
before the end of the eighth century. The architecture and organs of Venice served as models for the first church-builders of the North, and Venetian workmen were frequently employed by northern princes and bishops. For example, Louis the Pious, in 826 , employed a Venetian priest to build an organ at Aix-laChapelle. Bells were cast at Venice as early as the ninth century, apparently without assistance from the East. The manufacture of glass was begun at an early date and became one of the most famous industries of the city. Like the other industry named above, glass manufacture was chiefly important because of the ecclesiastical demand. Other ancient and celebrated Venetian manufactures were cloth-of-gold and purple cloth. The profits from these were enormous. The customers were, of course, only the wealthiest nobles and princes. Charlemagne himself was seldom seen without a robe of Venetian manufacture. Various iron manufactures were likewise important, though the raw material had to be imported, first from the Saracens, later from Saxony. ${ }^{x}$ But the metal industries could never be monopolized as the glass industry was. The most extensive business was in bells and ornamental ironwork, while the Saracens excelled in the manufacture of arms.

Without going into the details of Venetian manufactures and commerce, it is still easy to see that a basis was furnished for the scanty commerce that was carried on throughout the agricultural period and for the more extensive operations which arose as soon as European agriculture began to yield a surplus. The commodities handled were altogether luxuries for the wealthy and articles for the embellishment of churches. The most extensive trade was in commodities brought from the East, and the manufactures of Venice, while adapted to the demands of trade; were ever based upon eastern or old Roman models. The city itself was scarcely a part of Europe. It was never identified with the Germanic empire, and while religious sympathy may have had something to do with the part taken in the Crusades, the ideals of Christendom had little to do with the control of

I Hazlitt, History of the Venetian Republic, IV, 27I-79, 344-49. 
Venetian life. Even the crusading activity was chiefly for commercial gain, and frequently more sympathy was shown for the infidel than for the Christian. ${ }^{x}$

Because Venice acted chiefly as a channel through which the products of the older civilization were carried to the new Europe, the social and political history of the city is of little importance in our present study. Like the cities of the later Roman Empire, the government was republican. The assembly of the people decided upon the common interests and sanctioned the local laws. This assembly named the local magistrates who performed judicial functions. Each of the principal islands had its tribune chosen by its own inhabitants. These tribunes sometimes came together to consider common maritime interests, but their chief function was to administer justice in their respective islands. The Venetians, no more than any other people of antiquity, knew nothing of representative government; and so, after many internal dissensions, the General Assembly in 697 agreed to select a chief with the title of "Doge" to direct the common forces. A balancing of powers not being easily accomplished, the Venetians kept their General Assembly in order to be free, and made their chief a monarch in order to be powerful. ${ }^{2}$ Not being a mediæval community, that is, having none of the economic characteristics of the communities we have been considering, feudal institutions were practically unknown in Venice. All classes were engaged in commerce and industry. Therefore, while some might be held in higher honor than others, the military-economic organization of the manor could not exist. The artisans held social position according to the importance of their crafts. A servile class was found in the city, but it was never employed otherwise than in a menial capacity. ${ }^{3}$ The laws of the city were based directly on the Roman system, or rather, were simply the continuation of the laws in force at the time the city was founded.

I "The maritime republics fought for their purses, not for their creed. Baldwin and the princes of Europe fought for their creed without regard for their purses, and such enthusiasm naturally did not long prevail."-Bent, Genoa, 32.

2 Sismondi, op. cit., I, 224-29.

3 Filiasi, quoted by Hazlitt, op. cit., IV, 329, 330. 
The Justinian Code was not rediscovered at Amalfi until I4I6, but the Venetian code, completed in I242, was full of Roman elements. Everything goes to show that the city belonged to the old order, simply modified to meet peculiar commercial and geographical conditions. And yet this republic, whose beginnings antedated the fall of Rome, survived by three centuries the fall of the mediæval republic of Florence.

Florence.-Unlike the two cities just described, Florence was a true product of the Middle Ages. The fertile fields of Tuscany soon began to produce in abundance the food supplies which were obtained with such difficulty in the North. The agricultural population being predominantly Roman, and Roman methods of irrigation and cultivation having been fairly well preserved, the results throughout northern central Italy were far more satisfactory than they were in the other countries we have considered. Therefore, there earlier arose a demand for such products as the maritime cities could supply in exchange for the agricultural surplus. For the same reason a class of artisans could sooner be detached from the agricultural workers. These artisans could begin their crafts under more favorable circumstances than those under which their northern brethren labored, because there was a greater opportunity to learn the traditions of Roman industry. These facts can account for the artisan population which laid the foundations of Florentine greatness.

The beginnings of these settlements of artisans and small traders are unrecorded; but we know that by the tenth century well-defined gilds existed side by side with associations of the lesser nobility who had settled in the same region and had built castles for mutual protection. Long before Florentine commerce became significant, a large population was practically self-governing, being divided into numerous small associations; and when the communal government was formed to co-ordinate the existing group organizations, it was constituted on the basis of the gilds of arts and trades and the "societies of the towers." The consuls were almost invariably chosen from the latter, but the gilds predominated in the council, and the whole policy of 
Florence was made to serve the trade and commerce of these organizations. ${ }^{\mathrm{I}}$ The organization of the city was perfected during the struggles between the Countess Matilda and the Emperor in the latter part of the eleventh century. Until the latter part of the thirteenth century, only seven gilds had arisen to any great political importance, but these always remained the "greater gilds," because they were the ones whose foreign interests dominated the policy of the city. During the entire period, the lesser nobility and the tradesmen lived together in harmony. Indeed, some of the grandi engaged in commerce and became chiefs of gilds. But the greater nobility living outside the city were not accorded rights of citizenship. With these the commune was constantly at war, until they were finally overcome and compelled to come into the city and acknowledge its authority.

The scope of the commerce and industry of Florence is indicated by the names of the gilds which were in existence at the beginning of the fourteenth century. These were the following: Judges and Notaries-composed of the professional classes which had become necessary instruments of prosperity; Calimaladressers of cloth procured in Flanders and neighboring regions; Lana-a religious order engaged in the manufacture of wool brought chiefly from England; Silk - manufacturers of the raw silk imported from the East; Money-Changers-bankers and brokers both at home and abroad and usually in control of the revenues of the Holy See; Doctors and Druggists-dealers in both drugs and spices imported from the East; Skinners and Furriersdealers in pelts of rare animals brought both from the Orient and from the Baltic regions. These constituted the "Seven Greater Gilds." They were always interested in maintaining the foreign commerce, in waging wars for commercial advantage, and in preventing extravagance in the city itself. The other fourteen gilds were known as the "Lesser Gilds." These were the Linen-Makers and Mercers, the Shoemakers, the Smiths, the Salters, the Butchers and Slaughterers, the Wine-Dealers, the Innkeepers, the Harness-Makers, the Leather-Dressers, the Armorers,

I Villari, op. cit., I, I27, 128. 
the Iron-Mongers, the Masons, the Carpenters, and the Bakers The number of lesser gilds varied from time to time. These had no immediate interest in the foreign policy of the city, but rather desired that a rich and idle population could be encouraged. Their members were more numerous than those of the greater gilds and served as the material for demagogues to work on when differences arose. The greater nobility of the Contado, when forced to come into the city, naturally sided with the lesser gilds; and the Medici, while not belonging to nobility, finally gained control of the government by appealing to this class. In addition to the industries carried on by the gilds, there were others which reflected great honor on Florence. But the famous carvers of wood and stone, the wax-molders, etc., formed no associations, and were regarded as artists rather than artisans. ${ }^{\mathrm{I}}$

The republic was thus a federation of gilds and associations of petty noblemen. During the troublous times of its early history this characteristic was a source of strength, in that the members of the various groups received a discipline in co-operation which the State could not give, and the separate groups could continue their activities with comparatively little interruption even when the central government was overthrown. But the divergent interests of the two classes of gilds led to bitter conflicts within the city; and when commerce began to decay, the masses who had been held down by the powerful merchant-burghers, looked to monarchical rule for relief and put the power in the hands of Cosimo de Medici. The history of Florence is the history on a somewhat enlarged scale of every mediæval Italian republic except Venice and the Greek cities of the far south. Genoa, Milan, Rimini, Lucca, and all other the petty states were the product of the same kind of commercial activity; and all of those which did not fall in the commercial wars which they had waged with one another finally passed under the rule of princes who were supported by the rabble. Their great prosperity and sudden decay

IVillari, op. cit., I, 312-47; Doren, "Entwickelung und Organisation der Florentiner Zünfte," in Schmoller's Staats und socialwissenschaftliche Forschungen, $\mathrm{XV}, 7 \mathrm{ff}$. 
were alike due to the peculiar nature of the commerce they carried on. When they fell at one another's hands, their destruction was due to the same cause.

The decay of the southern cities.-This commerce was essentially a trade in luxuries with peoples who could be exploited for a time, but who, in time, were able to produce for themselves. No better illustration of the character of this trade at its best can be found than in the case of the two great gilds of wool of Florence. The wools of Italy were inferior in quality and quantity to those of northern Europe. In Flanders, Holland, and Brabant the art of weaving was so long established that the origin of the craft was lost in almost prehistoric times. Carried on for some time as a manorial industry, opportunities for trade early led to the differentiation of a distinct artisan class. When the English wools could be imported, even a larger number could give up agriculture for spinning and weaving. When the Italian traders, Jews and "Lombards," visited these regions with their little packs of spices, jewels, and fine garments, they naturally became acquainted with the value of the woolen cloths and tried to utilize to the greatest advantage the pieces which they received in exchange for their commodities. The Florentine merchants became the most extensive dealers in these products. They discovered that these cloths were made of yarn of the very best quality, but that they were woven in a coarse manner and sent to market undressed and dyed in ugly and evanescent colors. Accordingly the Florentine merchants imported these cloths in large quantities in order to dress and dye them in their own workshops. This became the work of the Calimala craft. The fine cloths thus produced by these workmen were sold extensively in the East, and finally in France, England, and in the very countries from which the rough cloth had come. The Arte di Lana, or Gild of Wool, which manufactured cloth from the raw materials, had a somewhat different origin, but likewise depended upon England and the Low Countries for the basis of its industry. This great gild was controlled by a monastic order known as the Umiliata, which was formed by a few Lombard exiles who had been ban- 
ished to northern Germany by Henry I in ror4. The exiles learned the art of weaving practiced there, and continued to carry on the business after they had returned to Italy and had formed a pious association. They soon ceased to labor with their own hands, but continued to carry on and improve the industry they had established. In the thirteenth century they accepted the invitation of Florence to settle in that city. The cloth manufactured by this gild took equal rank with that imported and improved by the Calimala. This trade in woolen cloth of fine texture became the most important carried on by Florence, and perhaps surpassed any other industry on the Italian peninsula. In 1338 there were more than 200 wool factories turning out 70,000 to 80,000 pieces of cloth valued at $1,200,000$ florins; and the Calimala had twenty warehouses in Florence receiving more than 10,000 pieces of cloth valued at 3,000,000 florins, besides immense stocks handled at factories which it had established in Northern Europe. ${ }^{x}$

These two gilds were always in a difficult position, since Italy could not supply them with sufficient raw material, nor could they obtain the number of hands required to carry on all the work connected with their business. . . . . While pursuing the system of keeping the finer and more profitable processes of the manufacture in their own hands, the Florentines had opened factories for the first and coarser stages of the work in every place where the best wool could be found; that is, in Holland, Brabant, England, and France. And even in these factories they took care that the more difficult and profitable share of the process should be done only by Florentine hands. . . . . But this state of things could not last long. . . . . Gradually the eyes of the northerners were opened, and the Florentines saw new factories rising abroad, side by side with, and soon rivaling, their own; and were obliged to admit that to their own despite they had taught the foreigners the very trade of which they had meant to preserve the monopoly. Nor was this the end of the matter. Being now on the alert, the northerners tried to check the exportation of ' their wools and of their uncut, or rather undressed, cloths; and from the end of the fifteenth century Henry VII of England began to take measures to that effect. Thenceforth the gilds of Wool and Calimala were doomed to decline in Florence. ${ }^{2}$

Villari, op. cit., I, $316 \mathrm{ff}$.

Ibid., 32I, 322. 
The effect of this kind of trade on the northern peoples would have been most exhausting, had they not gradually learned to manufacture for themselves. A trade in luxuries only is always exhausting to the ruder people and immensely profitable to the merchant class. So, the Greeks exploited the barbarian races, the eastern merchants exploited the Europeans of the Carolingian period, and modern civilized nations exploit the lower races with which they deal. Had this trade in luxuries remained merely a trade in luxuries, it would have resulted in the economic ruin of the northern peoples. Happily, it served to open the commercial routes, to stimulate a division of labor which helped to break up the manorial system, and to furnish models for the northern artisans which led to the general improvement of their products. Further, so long as the commerce of exploitation was carried on, whatever benefits the northerners received were for the upper classes only. Nothing brought from Italy and the Orient could possibly pass into the hands of the common people; and the common people could receive nothing beyond the rough necessaries of life so long as they were merely feeding the Italian factories. Of course, the cloth-weavers were turning out commodities which would clothe them more comfortably than had been possible when they lived on the baronial estates; but neither these nor any other of the laboring classes could advance their standards of life very far until commerce should handle many other commodities in addition to the luxuries brought from the South and the raw materials and coarse manufacturers taken away. Conditions were thus somewhat like those which prevailed in Athens at the time of her greatest prosperity. As we shall see later, the peoples of northern Europe were saved from a permanent commerce of this sort.

The Italians made known to the peoples of the North the products of the East and South. They also opened the routes of commerce and stimulated men in all sections to engage in trade. They cleared the seas of pirates and carried the crusaders to the Holy Land and other places of higher civilization. They maintained friendly relations with the Saracens who were the greatest 
traders and, in many respects, the most cultured people of the Middle Ages. They kept in touch with Byzantine civilization. They trained artists and architects who became the teachers of the North, when the latter began its great architectural works. They furnished a splendid currency in their ducats and florins for the use of the commerce of the whole world, and thus did away with the necessity of barter when communities were struggling to enter into relations with other communities far distant from them. They provided a credit system through their bankers and letters of exchange which must have been as important at the time as our credit system is to modern commerce. No account of the evolution of European industries would be complete without a recognition of the part played by the commercial cities of Italy and southern France in carrying over the results of the older civilization and starting the newer society on its commercial career.

Yet the effect of this trade on the Italian republics themselves was not altogether beneficial. The merchants became immensely wealthy. The ruder peoples, as we have seen, were exploited. The commerce of the world as a whole was very meager, but its profits fell to a relatively small class. The merchants of the southern cities, so long as they were few in number, found their profits limited only by their ability to press into new regions. The commercial republics became magnificent and powerful because of their ample resources. This wealth coupled with the technical skill which was being developed made possible the artistic and architectural works which followed the expansion of the national spirit. But this commerce produced an aristocracy of great merchants. While the smaller artisans shared in the general prosperity, their condition was always comparatively mean. The inability of the masses to raise their standard of living under a trade in luxuries has already been explained; but even the merchants and artisans of rather high grade were here also kept in a depressed condition, if their business depended solely upon local consumption. The wealthy burghers were those who carried on this profitable foreign trade. These directed the policy of the State, and this policy always aimed at the promotion of the com- 
merce carried on by the great merchants, without regard for the interests of the other classes in the community. Local consumption was actually discouraged. The interests of the two classes of business were by no means identical; and as soon as the foreign commerce began to fall off and the general prosperity incident to it to decline, these smaller craftsmen were very ready for revolution. But during the continuance of the extensive foreign operations, the political power was made to serve commerce, and the political functions were exercised by the commercial aristocracy. In the most prosperous days of the republic, Florence had but three thousand citizens.

In addition to the internal dissensions, the peculiar kind of trade carried on by the the Italians engendered jealousies among the cities themselves. These jealousies of cities toward one another and their inability to form leagues have been attributed to some inherent weakness of the Italian political capacity. In reality, however, the political strife was a necessary result of the kind of commercial activity, and there is no evidence that an Italian Hanseatic League could not have been maintained had the economic conditions been the same as those in the North. A commerce which is chiefly an exploitation can not bear competition. If the customers are to be drained by the operations of the merchants, there is just so much to be secured, and competition would mean division; whereas if the trade increases the productive power of the customers, competition causes only incidental friction. The commerce carried on by the Italians did not exhaust their customers; but the policy of the former was to drain the latter as completely as possible. Each commercial community found profitable fields to be worked, but none would permit another on its reservations. Merchants already engaged in a business would not permit others to enter their associations; and if merchants from another city entered an established market, that city immediately became a rival to be suppressed by war. There was no division of labor between the cities, nor, so far as the advanced processes of production were concerned, between the North and the South. The people of the North, perceiving the 
enormous profit in the business carried on by Italains, began to produce the very commodities of which the Italians had been monopolists, and the latter were driven from many of their markets. This threw the Italians back once more to a commerce almost exclusively in those commodities which their vessels brought from the Orient. The restriction of the markets led to fresh rivalry for the control of such as remained; and on the decline of prosperity a people is always most intolerant of rivalry. After a fresh readjustment on the new basis, a profitable trade might still have been kept up by many of the sea-going merchants; but this was prevented from reaching its fullest proportions by the social and political disturbances which the loss of so large a share of the market caused at home; and before the genius of the people could reassert itself, the conquests by the Turks, made possible in large measure by the ruinous wars between Venice and Genoa, shut off communication with the East and gave a stimulus to discovery which led to the rise of maritime powers on the Atlantic. But before this final decay of Italian commerce many of the cities had been completely ruined by these rivalries growing out of competition in the diminishing markets.

A still further cause of friction was the competition for commercial privileges in the East. There it was essential to secure monopoly rights in order to keep down the prices of commodities purchased; whereas in the North it was important to prevent too many from getting into a limited market, which being exploited would yield its whole resources to a few as readily as to many. Thus, in both East and North the nature of the trade carried on rendered the Italians intolerant of competition. Therefore, Pisa utterly destroyed Amalf; Florence utterly destroyed Siena and Pisa; Genoa attempted to destroy Florence; Venice and Genoa were constantly at war both on the seas and in the eastern cities where both held concessions. Moreover, the citizens of a conquered commune could not become citizens of the one that conquered them, nor hope to have the commerce of their city preserved. The conquering city could not find it profitable to permit the subjugated community to continue to compete with it, any 
more than the ruling burghers could permit newcomers to enter their gilds. Throughout, the political activity was directed in the interests of a commerce which could not tolerate competition. The commune was managed as a counting-house.

The character of Italian commerce thus made impossible the unification of Italy, or even the formation of a league of commercial cities. It also rendered the general population of a given city helpless so long as the commercial interests could be kept predominant. "The commune seemed increasingly incapable of giving birth to the modern State." Therefore, when commerce began to decay, it became easy for demagogues to become tyrants; for the general welfare was much better promoted under a tyranny than it had been under the magnificent but selfish merchant-aristocracy. Thus the communes of Italy were reduced to principalities.

This transition was hastened by the practice of employing bands of condottieri as temporary standing armies, after the introduction of heavy cavalry made it impossible to keep an industrial population in training for war. Each of the invasions of northern princes who hoped to establish a united kingdom of Italy left behind many adventurers who were glad to become mercenaries. In time, as the smaller republics were overthrown by the larger, their more energetic citizens formed military companies. Many of these were little more than brigands, and few could be depended upon to keep their contracts when employed by the cities. The captains of these bands frequently became the tyrants of the cities in whose interests they had been hired to fight. In addition to their employment to fight the wars of the communes, the captains of mercenaries were often appointed podestas to keep the peace between the various factions within the cities. Here they soon became too strong to be dislodged. Venice never introduced the mercenaries within the city, but, while uniformly employing them to fight the land battles which were necessary to hold an agricultural region and the passes through the Alps by way of Belluno, she always manned her ships with native crews. Venice was thus saved from the fate which befell all other Italian republics. In some cases the tyrannies 
were established before the employment of mercenaries began, either because the dissensions among the citizens gave some powerful family the opportunity to obtain control, or because it seemed necessary to have a single strong leader in a critical struggle with neighbors. Thus Florence, in desperation over the growing power of Pisa, chose Walter de Brienne in 1343 to act as dictator; but in this case, when the dictator attempted to make himself permanent tyrant, all classes united to drive him out; and the Florentine republic outlasted all the rest, and finally passed under the power of a non-military family. However, the republics were all alike doomed to fall because of the dissensions between the great merchants and the other classes. By the end of the fifteenth century, every Italian city except Venice had established the signory. The Visconti family in Milan, the della Scala in Verona, the Carrara in Padua, the Este in Ferrara, the Malatesta in Rimini, the Bentivoglio in Bologna, the Gonzaga in Mantua, the Medici in Florence-everywhere princes arose to displace the older form of government. Even the Holy See became a tyranny which promised to pass permanently into the family of the Borgia.

But however violent and unconstitutional the origin of the signory, however ignoble the origin of the tyrants, the form of government thus established was the best possible under the circumstances. The welfare of all classes was better secured than under the republic, and the signor ruled as an organ of public opinion. Civilization was not arrested or turned aside even when the tyrant was a rude foreigner. Indeed, he endeavored to strengthen his position by becoming the patron of art and by making the results of the highest culture available for the public. The splendor of the court was made to take the place of ancient lineage. Polenta of Ravenna became the patron of the proscribed Dante, and Cæsar Borgia made possible the best works of Leonardo da Vinci; the signor of Pesaro was the friend of Petrarch, and the signor of Rimini employed Giotto to paint frescoes on the walls of St. Francis. The philosophers and poets of the Renaissance could free the minds of men alike from imperial 
authority and ecclesiastical terrors, even while their patrons gave nominal allegiance to one or the other of those declining powers. The control of military resources by the signor assured the autonomy of the State, while the decay of the commerce of exploittation saved neighboring cities from the wars which had been so constant under the preceding régime. The vigorous podestas who had first been called in to quell the disturbances caused by the quarrels of merchants and populace, of Guelfs and Ghibellines, rescued their principalities from the heavy burdens of both the Empire and the Holy See. While, therefore, a sentimental interest may lead us to regret the fall of the vigorous merchant burghers and the failure of such monkish reforms as those instituted by Savonarola, a consideration of the social conditions of Italy must convince us that the signory was the natural political. organization for the time. ${ }^{x}$

The economic conditions in Italy had rendered impossible any such co-operative league as was formed in the North. The reason for this has already been stated. But the early development of commerce and the struggles between Guelfs and Ghibellines had resulted in such an undermining of feudalism as left no noble strong enough to consolidate a National State, as Philip Augustus and his successors did in France and the Hohenzollern did in Prussia. As the economic competition had made the commercial league impossible, so the destruction of feudalism made the National State impossible. The emperor had supported the feudal nobility; the pope had protected the burghers and the urban nobility. The constant dissensions, of which the most acute was that between Gregory VII and Henry IV, ruined feudalism, and enabled the urban population to establish the republics. By the year $\mathrm{I} 200$ there was no longer a single independent noble in all Lombardy; in 1209 the last of the Tuscan seigneurs were obliged to move into Florence. By the middle of

ICf. Villari, op. cit., I, 346-59; Gebhart, Les origines de la renaissance en Italie, 84-86, 103-1 7; Yriarte, Rimini: études sur les lettres et les arts d la cour des Malatesta, I-3, 7-10; Symonds, The Renaissance in Italy: The Revival of Learning, chap. ix. 
the thirteenth century, the house of Hohenstaufen had been crushed; and within fifty years of that time, the papacy had received the reverse at Anagni which forced it into exile. ${ }^{x}$ Thus, Italy was left free to work out its own political structure, and succeeded admirably in doing so under both republics and signories; but it was impossible to effect a larger integration both on account of the lack of a natural economic basis and because of the inability of the political powers to shape the economic development with reference to the development of a national life. Milan under the Visconti family gave greatest promise of growth into a large national state, but rival principalities proved too strong to permit either the territorial expansion or the internal development of the duchy. The freedom and cosmopolitanism of the Renaissance in Italy tended to render men indifferent to national unification; just as many of the most enlightened men of Germany were indifferent or hostile to the formation of the present empire. Thus, Italy remained cut up into a number of small signories, until the whole peninsula fell into the chaos which continued up to the middle of the nineteenth century. After the fall of the commercial republics which had set the pace for European industry and the passing of the men of the Renaissancethe product of the commercial development and the pride of the earlier signors-who gave the first stimulus to European thought, Italy ceased to have any essential part in the development we are tracing.

\section{THE COMMERCIAL LEAGUES}

Turning once more to the main current of European life, we find a larger social integration growing out of the economic development we have traced. Attention has already been directed ${ }^{2}$ to some of the political movements which aided in the development of the towns. It was shown that some of the great feudal lords, as the kings of France and the lords of the northern counties, came to the assistance of the communes, in order to undermine their vassals who were the seigneurs of the towns; that the absence

I Gebhart, op. cit., 92-96; Yriarte, op. cit., 6, 7.

2 Supra, 210-13. 
of a great feudal power in Germany made it necessary for the towns to form leagues, both to exact terms from their immediate seigneurs and to contend with the imperial power; that in England the strong royal power took a paternal interest in the commercial towns whether located on the royal domain or on the domains of the nobility. Now it is desirable to notice the commercial interrelations of the northern towns, and to observe how the character of the trade carried on between them furthered a genuine division of labor and, therefore, tended to constitute the whole of northwestern Europe a single community.

This trade was not, like that carried on by the Italians, a trade primarily in luxuries, though such a trade undoubtedly played a most important part in the first stages of every new commercial movement. Every new article of commerce was likely to be a luxury; but luxuries gradually became necessaries, and the commodities of commerce became so various that a genuine division of labor could be made. The products of each considerable section were wanted by every other section, and it was to the interest of all that the productivity of each should be as great as possible. This interest was not always consciously recognized, but it was real enough to bring about important co-operative systems. Within small areas there might be very bitter rivalry between towns which produced the same commodity, and all towns pursued a very narrow policy, when it came to trading within their respective retail markets; but, on the whole, the competition was incidental rather than radical. It was to the recognized advantage of the entire Low Countries that the English wool product should be as great as possible. It might be profitable for the individual merchants to make exhorbitant profits in buying wool, but it was the general policy of the clothproducing cities to carry on a fair trade that would stimulate the continuous production of wool. No single city ever having monopolized the market, the competition of the groups of merchants from various places served to keep up the prices; but this competition was taken as a matter of course, and never led to such struggles as took place when one Italian city entered a field which 
another had come to regard as its own. So, the commercial world at large desired a large product from the cloth-producing communities. Within the cloth-producing area there might be a bitter rivalry, as between Arras and Bruges, for the control of a certain product, yet the rivals could co-operate harmoniously when they came together in foreign operations. Within a given city not even the merchants of the most favored neighbor could trade on equal terms with the home merchants, and goods passing through the city had to be opened and exposed for sale. ${ }^{x}$ But these internal restrictions were taken as in keeping with the universal policy of the times.

The most important center of commercial activity was England, the country which was least advanced in manufactures; and the commercial leagues find their chief explanation in the relations of their members in that country. This important trade was not in the hands of English merchants. The latter had to do only with the internal trade. The raw materials produced by England, of which wool was the most important-though tin, lead, fish, fat cattle, meat, and grain were exported in large quantities by the twelfth century ${ }^{2}$ - were needed by all of the industrial communities of northern Europe; and it was natural that the merchants should come from the communities which produced the finished products, rather than from the more backward country. English policy protected these foreign merchants until efforts were begun to build up home industries. As early as 1215 their freedom was guaranteed by the fundamental law of the kingdom. ${ }^{3}$ Until the time of the Tudors, the general policy of the monarchs was to favor foreign merchants who traded in England. The reasons for this will appear later.

Here, as elsewhere, the Italians were the pioneers. They first entered England, not as traders, but as the fiscal agents of the

I On the internal policy of the towns, vide Schmoller, The Mercantile System (translated by Ashley from Studien über die wirtschaftliche Politik Friedrichs des Grossen), 7-13.

2 Craik, History of British Commerce, I, 105. The chief authority here is Henry of Huntingdon (ca. I155).

3 Magna Carta, \&4r. 
Holy See which availed itself of the sound money systems and skilful bankers of Siena, Lucca, and Florence. These Italians soon took advantage of their opportunity to bring in those wares which had formerly been brought in in very small quantities by wandering traders. Their position was strengthened by their diplomatic ability and by loans to the crown. By the middle of the thirteenth century, England swarmed with Italian merchants, chief of whom were the Florentines, exchanging their wares for English wool. Their position was weakened in the time of Edward III; for they had loaned too heavily to that monarch, and lost his favor when he saw that he had exhausted their resources. Later, Genoa was greatly favored on account of her sea-power and her proximity to France. Henry $\mathrm{V}$ gave the Genoese advantages over all others in order to keep them at least neutral in the struggle between England and France. On the accession of the York kings, however, Venice was enabled to take the place of Genoa; but before this time relations with Flanders and the Hansa had become more important, and the kings no longer granted the Italians special favors. The last time the Venetian fleet visited England was in $1587 .^{x}$

We have already noticed the early rise of the cloth industry in Flanders. By the time this had become of more than local importance, the weavers were depending largely upon England for their wool. From the beginning of the eleventh century the intercourse between the two regions, which had never been entirely broken off, came to have a profound economic importance and frequently had a controlling influence in high politics. The favorable climate and soil of England and the relatively permanent peace, at a time when continental flocks were being destroyed by constant wars, enabled the English to enjoy a virtual monopoly of wool. As in all other industries, the monasteries led in woolgrowing, the Cistercians maintaining the largest sheep-ranges; but from the twelfth century nearly everybody in the realm, from king to villein, was interested in the industry. ${ }^{2}$ Much of this I Cf. Schanz, Englische Handelspolitik gegen Ende des Mittelatlers, I, Ir626; Gibbins, Industry in England, 225, 226.

2 Gibbins, op. cit., 120, 121. 
large clip was worked up on the manors for home consumption. This cloth was produced by men who gave but a small portion of their time to weaving, and was too coarse for export. Not until the reign of Edward III was any serious attempt made to manufacture better grades of cloth at home, and not until the Tudor period did the English industry begin to surpass the Flemish.

There are several reasons for this long-continued export of the raw material and import of manufactured products. Chief of these, of course, was the economic advantage of this kind of trade. England could produce a commodity which Europe needed and which few other sections could produce. On the other hand, Normandy and the Low Countries could manufacture cloth which no English workmen could produce. The processes which had been handed down by tradition were in every sense a "mystery," and when the skilled artisans learned still better methods from the Italians, their craft was ever further beyond the English workmen of the time. It was therefore unprofitable to attempt to manufacture cloth of the better grades at home. When, finally, the industry was built up in England, it was by importing Flemish workmen. Under these circumstances, the way of economic advantage lay in a complete division of labor between the two regions. $^{x}$ On the political side, the tendency to maintain a complete division of labor was strengthened. In the first place, taking advantage of the economic law whereby the burden of a tax on a monopoly export may be thrown on the foreign consumer, the English kings were able to secure large revenues by laying an export duty on wool-greater by far than they could have secured from an import duty on cloth. Self-interest, therefore, led them to further, rather than interrupt, the natural economic movement. Of equal importance was the political interest of the English kings in alienating the Flemings from their feudal and natural compatriots, the French. In all of their operations against France they sought to strengthen the bonds which united Flanders to England, in order to secure a base from which to enter France

schmoller, Strassburger Tucher- und Weberzunft, 365-67; Ashley, History of the English Woollen Industry, 333-35; Schanz, op. cit., I, chap. I. 
and the assistance, or at least the neutrality, of the Flemings. The two countries which formed one economic community promised to become one in political organization. In every case the economic interests of the industrial communities determined their political action; for though the English would suffer great inconvenience from the breaking-off of commercial relations with the Flemish, they could still feed and clothe themselves; while the Flemings would be reduced to starvation by the cutting-off of the supply of English wool. ${ }^{\mathbf{x}}$

Thus we find every reason for the protection and favor given to the foreign merchants by the English government. On the Continent, until the rise of the French nation, there was no political power which could exert as great an influence over commercial intercourse as the English kings did in compelling the merchant communities to serve their political ends. And so it came to pass that an economic community was formed which went beyond any political community, and which, before the rise of the national states and the development of international law, gave fair promise of forming a political structure of its own. The English merchant communities were too passive and the crown too strong for a development in this direction in England; but in Flanders and northern France, before the French monarchy was well established, the commercial league became very strong, and in Germany it remained a real political power for a long period; while Flanders and England tended toward a political amalgamation corresponding to the community of economic interests. The commercial leagues never quite reached a true political organization; but they had a marked influence over the later political development, both in establishing certain habits of commercial intercourse, which made it forever impossible to go back to the old practices of piracy and reprisal, and in setting an ideal of industrial activity, which was afterward the standard for the great politicians who laid the foundations of the modern states of the North.

The earlier league-at least as an important factor-known as

I Schanz, op. cit., I, II-19; Gibbins, op. cit., 121-24; Lodge, The Close of the Middle Ages, 70-72. 
the Hanse of London, was formed primarily, as its name implies, for the control of the English trade. This was formed prior to the year $\mathrm{I}_{20}{ }^{\mathrm{x}}$ and lasted into the fifteenth century. This league included some seventeen important towns, among them the chief commercial centers in Flanders, and, for a time, Chalons, Rheims, St. Quentin, Cambray, Amiens, Beauvais, and possibly Paris. It was maintained strictly in the interest of the merchant bodies which controlled the affairs of their respective cities. Their interests being predominantly economic, and the need of political action not being very pressing, these cities never made a very close approach to a political organization. Still the league secured protection for its members and stood as a political whole over against England. ${ }^{2}$

The Teutonic Hansa, on the other hand, while springing up because of conditions similar to those which produced the Hanse of London, was forced by circumstances to perform political functions scarcely less important than those of great states. This great league was the outgrowth of several smaller leagues which had sprung up spontaneously in various parts of the Empire. In southern Germany the towns frequently formed alliances to resist the territorial princes and to obtain security for traveling merchants and immunity from excessive tolls; but the southern cities were situated in a region which had become tolerably advanced in civilization, and they could afford to maintain independence and isolation. The northern cities, on the other hand, had important relations with neighboring states which were much below themselves in civilization, and were obliged to form alliances of a relatively permanent character, both for collective bargaining and for genuine political action. ${ }^{3}$

The important trade of the Baltic and the North Sea and the fisheries of those waters were the basis of the prosperity of many towns from the Weser to the Niemen; while the trade which

I First mentioned at this date in a charter of Bruges, Warnkœnig, Histoire de Flandre, II, 207.

2 Ashley, History of the English Woollen Industry, 33 r, 332.

3 Lodge, The Close of the Middle Ages, 422, 423. 
passed down the Rhine valley caused the rise of a chain of towns along that river, interested alike in the southern trade and in the commerce of the North Sea. Tributary to these two groups of cities were many inland towns of less importance. For a time there was no very close relation between the towns of the North Sea and those of the Baltic. At the head of the former group stood Cologne, though Hamburg and Bremen became important rivals of the capital of the Rhine. The center of the Baltic trade was Wisby, a German city on the island of Gothland in the kingdom of Sweden; but by the thirteenth century Lübeck began to rise in importance, and finally became the leader of the Baltic cities.

The center of the operations of the Rhenish cities came to be London, where Cologne-the first of the German cities to attain to commercial importance $\mathrm{x}$ - obtained important concessions and had established the "Steelyard" by II 57. " This famous merchant settlement found its counterpart in all commercial centers where foreign merchants congregated. Some time was always required to dispose of a cargo; if bad weather set in before his business was transacted, the merchant frequently found it necessary to spend several months in the foreign port. Suitable inns, warehouses, and harbors had to be provided by the merchants who used them. Finally, since law was personal, rather than territorial, provision had to be made for the settlement of disputes among the foreigners who were sojourning together; and some support, more powerful than individual influence had to be given to the foreigner who had a difference with a native. For these reasons, privileges and concessions were necessary, if trade was to be carried on at all; and what the individual trader could not secure was frequently granted to the whole body of merchants who came from the same town or were engaged in the same trade. ${ }^{3}$ So the men of Cologne were given permission to form the first German hanse in London. A wealthy and

I Schmoller, Strassburger T. und W., 366.

2 Lappenberg, Urkundliche Geschichte des hansischen Stahlhojes zu London, 2. 3 Lodge, op. cit., 424, 425 . 
influential hanse once established was able to prevent other groups of merchants from securing similar concessions; and the English kings were much more willing to extend the scope of the grant to Cologne than to cause still more dissatisfaction among their own subjects by granting separate hanses to the many German cities which had commercial relations with England. ${ }^{x}$ Other merchants who desired to trade in London could obtain admission to the Hansa of Cologne on terms named by that corporation; and in the course of time the traders from all the Rhenish and Westphalian cities were admitted to its privileges. But when the trade of Hamburg with London became important, the merchants of that city could not obtain admission to the privileges of the hanse; nor could the Baltic cities, headed by Lübeck, when they began to trade with England. In 1266 and 1267 the English king granted Hamburg and Lübeck hanse privileges at Lynn on the east coast, and all other German cities which could not gain admittance to the "Steelyard" associated with Lübeck. The strength of this rival association was due to the alliance between Hamburg, the rival of Cologne on the North Sea, and Lübeck, the leader of the Baltic towns, to oppose the exactions of Denmark on the vessels passing through the Sound and frequenting the fishing-grounds off the coast of Skaania. Their common action marks the growth of common interests: the North Sea trade was reaching out to the Baltic regions, and the Baltic trade was expanding toward the West. Other towns interested in the passage of the Sound naturally allied themselves with these two cities; and Lübeck, having already come to be the recognized head of a large number of towns, was regarded as the leader of these allies. This alliance between Hamburg and Lübeck was the real beginning of the Hanseatic League; but the consolidation' of the Hansa took place in England, where the hanses of Hamburg, Lübeck, and Cologne were merged by the year I282.

Schanz, op. cit., I, I73.

2 "Out of this gild of merchants of Cologne arose the great Teutonic Hanse: first by the inclusion in the gild of all other German merchants who wished to trade in England, and afterward by the rise of Lübeck. For Lübeck, after vainly 
With varying fortunes the League continued to enjoy extraordinary privileges in England until its charter was finally rescinded by Elizabeth in 1597. But by that time its commercial power had waned and many of its constituent cities had been detached.

As London was the chief center of trade for the League in the West, so Novgorod was the most important center in the East. Novgorod was the most important of the many "factories" established by Wisby. As in civilized communities the merchants formed hanses for the protection of their interests, so in the uncivilized regions with which they traded they founded tradingcolonies which frequently grew into towns. These commercial stations played a most important part in extending Christianity and civilization into East Prussia, Lithuania, and Livonia. Novgorod was founded as early as the beginning of the thirteenth century, and early became the center of an enormous trade with the whole northeastern section of Europe. To facilitate the interior commerce, there were established secondary "factories," as Ladoga, Pleskow, and probably Smolensk. The chief articles of this commerce were furs, leather, wax, tallow, gold, and silver, among the exports; and clothing, flour, herring, Dutch and English cloth, copper, zinc, lead, wine, and smoked meat were imported for distribution in that region. ${ }^{x}$ Whether a route to the Orient was opened through Novgorod, as some writers have thought, may well be questioned; ${ }^{2}$ for the difficulties of travel through the intervening barbarous countries were so great that commerce would scarcely leave the Mediterranean route for this one. Nor have we any records of oriental trade passing through Novgorod.

London and Novgorod were respectively the western and eastern limits of the activity of the League. To the North a trade was carried on with the upper parts of Sweden and Norway and even with Iceland. This, of course, was much less important than that in the other directions. The most southerly Hanse trying to enter the Cologne confederation, founded a hanse of its own, to which that of Cologne soon became subordinate."-Ashley, History of the Woollen Industry, 333 .

× Worms, Histoire de la Ligue Hanséatique, 81-84.

2 Ibid., 84-86. 
cities were Dinant on the Meuse, Andernach on the Rhine, Breslau on the Oder, and Cracow on the Vistula; but the Hanseatic commerce was not restricted to the direct activity of members of the League, and some of the most important trade relations were with Venice through the passes of the Tirol and the German cities of Regensburg, Augsburg, and Nuremberg.

Going back to the Lübeck-Hamburg alliance of I24I which proved to be the nucleus of the Hanseatic League, we find the reason for the political activity of the League which so nearly led to the formation of a political structure. The union was formed purely in the interest of commerce, but in protecting commerce it was found necessary to assume political functions. That first union was formed for the purpose of dealing with Denmark. Some forty years later, an assembly was held at Rostock for the purpose of adopting measures to prevent Norway from continuing injuries which were being inflicted upon commerce by that power. All trade with Norway was cut off until redress should be obtained and it was further resolved that commercial relations with Bremen should be discontinued unless that city would co-operate with the others. For about a hundred years after the Lübeck-Hamburg alliance, similar unions of the cities of northern Germany took place. Different towns would unite at different times; and sometimes the League seemed to be on the point of dissolution. The joint action of the cities, while frequently directed against a nation, was usually of a purely commercial character, as the resort to trade reprisals, the adoption of commercial rules, or the regulation of the affairs of Novgorod. In the next period the distinctively political character of the League became more prominent.

After the aggressive policy of Eric Menved of Denmark (I $307-$ I9), that kingdom went to pieces, and the League became more active. Meetings became more frequent, and many new members were admitted. By the middle of the fourteenth century, a division of the whole confederation into three sections was recognized, with Wisby at the head of the far northern and eastern settlements; Lübeck at the head of the Wendish and Saxon towns, 
and Cologne at the head of the Prussian and Westphalian towns. Lübeck was recognized as the capital of the whole League. The event which brought the cities into closest association was the attack by Waldemar of Denmark on the city of Wisby in $136 r$. The representatives of the Hanse cities immediately decided to cut off all intercourse with Denmark, and at a second meeting entered into an alliance with Sweden, Norway, and Holland to make war on Denmark. A tax was levied for the war, which all cities were ordered to levy in the form of an export duty. The first action in which the League engaged resulted in a crushing defeat. A truce was entered into; but on the renewal of Danish aggression against German commerce, the Hanse assembly at Cologne in 1367 declared war again, and threatened any city that would not take part in the conflict with expulsion from the League. In 1368 Copenhagen was taken; the next year Helsingborg was reduced; the king of Norway was compelled to withdraw from the Danish alliance and to grant the Germans special privileges; and in 1370 the Danes entered into the Treaty of Stralsund, by which all the forts and two-thirds of the revenues of Skaania were granted to the Hansa for fifteen years, and the Danes agreed that no king should be placed on the Danish throne without the consent of the League. The occupation of Skaania and the protection of the fisheries and the navigation of the Sound were to be vested in the Hansa for but fifteen years; but the assumption of this responsibility and the necessity of watching the course of events in the three Scandinavian kingdoms compelled the League to maintain a permanent armament and to continue the system of federal taxation. The meetings of the delegates of the towns necessarily became more frequent, and the character of the business transacted naturally caused a greater consolidation of the League. The reputation gained in the Danish war and the greater unity brought about by the new conditions made the Hansa a power to be respected. The Hanse towns secured the duchy of Schleswig for Holstein, and constantly intervened in the struggles that followed the Union of Kalmar. Not only did the League exercise the functions of a state in dealing 
with foreign affairs; it also began to concern itself with the internal affairs of the constituent towns. When the craftsmen of the towns began to rebel against the merchant aristocracy, the League took the part of the latter, as in 1374 , when Brunswick was expelled from the League because the populace had overthrown the ruling council of merchants. Expulsion from the League would bring such distress to any commercial town that it became a sure weapon for the prevention of internal disorders.

Here we have both the external and the internal exercise of sovereignty. The political structure was never perfect, but it was quite as perfect as that of many communities whose territory was contiguous. Most of the Hanse cities owed allegiance to territorial rulers, but this allegiance was often merely nominal; and when it came to a choice between obeying the Hanse law and obeying the territorial law, it was usually safer to ignore the latter. The political structure was that of a strong confederation, but had the League continued to prosper, a true state might have been formed, in spite of the nominal territorial allegiance and the lack of territorial contiguity.

The failure to develop a permanent political structure was due to several causes, chief of which was the loss of commercial supremacy. In 1478 Novgorod lost its freedom before the advance of Russian power, and the civilization of that region suffered an eclipse. Soon after, the Prussian and Livonian cities were detached from the League. Sweden finally separated from Denmark, and the turbulent nobility of both countries fell before the royal power. Both countries began to build up national commercial associations to compete with the Hansa. In France the national power had developed so early that the cities had never been permitted to enter the League. In England the Tudors came to the throne, and were bent on building up national industries. The efforts of Edward III to develop the cloth industry had resulted in the manufacture of better grades of cloth, but it was not until the Tudor period that English manufactures could seriously compete with the Flemish and German. Before the final expulsion of the Hansa by Elizabeth, the English merchants 
were becoming an influential class. The fiscal arrangements of the crown, whereby staple towns had been established, resulted in the stimulation of the home merchants $;^{\mathbf{x}}$ and after the English cloth manufacture became able to compete with the foreign, the plan of organization which had been worked out by the staple merchants was used by some of them and by cloth-finishers, and the "merchant adventurers" undertook the exploitation of English cloth in foreign markets. ${ }^{2}$ This organization began operations early in the fifteenth century and led the way in building up an export trade in the hands of English merchants. ${ }^{3}$ As these merchants became more powerful, they began to contest the monopoly of the Hansa in the Baltic, and brought such pressure to bear upon the government that the League was finally banished from England. 4

Crippled by the loss of the Novgorod trade and by the growing power of the English merchants, confronted by stronger political powers in the North, the Hansa ceased to be an important factor; and when, about the middle of the fifteenth century, the herring which had been frequenting the waters off Skaania moved to the coasts of Holland, another great source of profit was cut off. While a few of the members continued to derive some advantages from association, the once-powerful organization dwindled into insignificance. Based chiefly on the control of commerce between the two extreme centers of trade, when this was lost there was no enduring structure that could withstand disintegration. ${ }^{5}$ And when we add to this misfortune, the loss of exclusive privileges in the Baltic and of the profitable fisheries which had supplied the demand of so many Catholic communities, we have a sufficient explanation of the decay of Hanseatic commerce and the disintegration of the League.

Here we note the difference between a commercial league and

I Schanz, op. cit., I, 327-3I.

2 Ibid., 33I-333; Ashley, History of the Woollen Industry, 353-58.

3 Ryner, Fædora, II, ro2.

4 Craik, op. cit., I, 233-35.

5 Schanz, op. cit., I, I8r. 
such national states as were springing up. Commerce, as we have seen, represented a real differentiation of function in the larger whole which had formerly been merely a mass of self-dependent communities held together in a rather artificial way by the common ideals which had been carried over from antiquity. Since the economic means had at last been found for the realization of the ethical end, it might be expected that a political structure would be developed that would comprehend all of the industrial communities amongst which a division of labor had been established for the benefit of the whole. We have already noted the tendency of political structure to conform to the economic division of function. The feudal organization, which meant the disintegration of Europe, had arisen because it corresponded to the economic organization of the manor. Again, when the economic activities went beyond manorial groups, the latter decayed and a movement began in the direction of a larger political organization which would correspond to the larger economic activities. But this movement was arrested, and modern society still presents the spectacle of numerous political divisions in spite of the essential economic interdependence of the various parts.

The causes of this failure of the growing organic society to form for itself a single world-state were numerous. Among the most apparent were the differences of race and language. When the national states were finally established, we find that the divisions were made on pretty well-defined race lines. Differences of race meant differences in many minor ideals, tastes, habits, and temperament, which the great unifying ideals of Christendom could not obliterate. Linguistic differences were then much less important than these physical and psychical differences, for the languages of the West were still in a state of flux when the national separations precipitated the formation of the present linguistic groups and inspired the great national literatures. Still there were real differences in speech which tended to set different communities off from one another. Even the Germanic Hansa which was so little bound by considerations of race and language was predominantly German and stamped its Germanic character 
upon the outlying communities that came under its control. The commercial league tended to transcend racial lines, but was never wholly able to do so.

Geographical and climatic differences likewise tended to create and perpetuate differences in habits of life, and consequently, in ideals. The architecture, clothing, and food of one section would have to differ in some respects from those of another; and industries would therefore develop which could supply only a purely local demand and could not function for the whole of Europe. In proportion as these local activities determined by geographical conditions became important, they constituted an obstacle to the formation of a world-empire. Complete interdependence was not established; and many purely local industries were the most important of all carried on by the community.

One of the most important causes of the phenomenon we are considering was the fact that the economic activities frequently changed their direction very rapidly, while the political structure could be readjusted only gradually. A change in the supply or the demand of a given region might cause a complete dislocation in economic arrangements; but a society must have an organization which can live through good times and bad. It is true that an economic change may be so radical that the political structure will have to crumble, as we have already seen in more than one instance; but the structure of a society must be able to resist many temporary economic vicissitudes. In the case of the Hansa, which came nearest to forming a political organization on purely economic lines, the cutting-off of the Novgorod trade was sufficient to rack the whole organization, though the internal life of the constituent cities was not affected in such a way as seriously to endanger them. Their prosperity was lessened, but they were soon able to readjust themselves to new local conditions, and to maintain their community life much as they had done before. The position taken throughout this essay is that economic activities are fundamental, and must in the end determine social organization; but it is only in the earliest stages of culture that the economic life immediately determines ethical and political ques- 
tions. At a very early stage there emerge, as a result of the primary life-furthering activities, certain ethical, æsthetic, and political ideals and institutions which must forever after react upon the economic life, or even cause the latter to be temporarily disregarded. A given group may prefer poverty and political integrity to prosperity with a change in political institutions.

Now the great merchant burghers cared for little but economic advantage and economic advantage for their own class at that, and they frequently ignored many of the motives which impel men to political organization. It was by appealing to these other motives that the politicians could build their states. Only in times of greatest prosperity would the mass of the people-those engaged in agriculture, in the local crafts, and in subordinate positions in the commercial crafts-loyally support the merchant-aristocracy. In the Italian cities the populace quickly put the power into the hands of the demagogues. The northern cities did not meet with a like fate because their foreign trade meant a more general internal prosperity; but there was no spirit of patriotism which could hold the League together when economic advantage was no longer to be derived from association. Then, too, the leaders of a purely commercial organization did not care to exercise political functions except for economic advantage. The commercial cities could produce great statesmen and soldiers; the Hansa carried on war, negotiated treaties of peace and commercial conventions, and could coerce its recalcitrant members; but all of these activities were carried on chiefly in the interest of commerce. While a League patriotism was not wholly wanting, a given city would drop out of the association when its commercial interests were no longer served by its adhesion; and no steps were ever taken to enlarge the membership, or to bind the members more closely together, except for purely commercial ends. The national statesmen, on the other hand, regarded industry simply as a means to an end; and that end was the State.

The interest of the burghers, then, was in the economic means; that of the nationalists in the political structure. Both parties were losing sight of the ethical ideals of social life which had been 
the mainstay of Europe throughout the period of economic and political chaos. In this neglect of the ends of social life we shall find one of the chief defects of modern society. On the one hand, we find a tendency to ignore natural economic conditions and all other natural developments, or to use them simply to build up the strong State and to minister to a narrow chauvinism; on the other, there is an attempt to use the State as a mere machine for the getting of wealth. The State can not properly be made the end of social activity: it is only the mechanism for the adjustment of means to end; and yet, on the whole, it was more important at the end of the Middle Ages that efforts should be directed to the perfecting of even very artificial political organizations which could conserve what had already been attained and could serve as the starting-points for new developments, than that the industrial activities should wholly control and society be left structureless and at the mercy of every economic crisis or subject to the selfish plans of a merchant-aristocracy. It was in the interest of real progress that the commercial leagues passed away and left Europe to the national statesmen. ${ }^{x}$

\section{THE NATIONAL STATE}

The survival of the political traditions on which the national statesmen built is an indication of the strength of extra-economic forces in society with which the commercial statesmen could not grapple. When the agricultural organization was perfected and numerous domains began to coalesce, the stronger seigneurs prospered at the expense of the weaker. But a great lord's ability to extend his dominions was limited by the presence of some neighbor of practically the same strength, against whom it would have been madness to make aggression. When the communes

r.Worms gives an interesting account of the causes of the decadence of the Hansa (op. cit., 327-45); but most of these are secondary causes growing out of those discussed above. Religious differences, of which he makes a great deal, probably had little to do with the disruption of the League. The Thirty Years' War would have destroyed the League, but it was dead long before that period. The divisions which finally took place on account of religious differences coincided pretty closely with race differences which could have been reconciled only with great difficulty in a single nation. 
arose and threw off allegiance to the local seigneurs, they were usually very willing to acknowledge the nominal sovereignty of the higher feudal lords who had probably befriended them. When one of these greater lords had gathered together large dominions containing rich and populous towns and fertile fields, he was stopped from further progress because he had now reached the borders of some equally powerful lord. From conflicts among these great dukes and counts there resulted the elimination of some of the weaker and the aggrandizement of the stronger. A balance, however, was always reached somewhere, and no one dreamed of universal empire. There was no Charlemagne in the days of Louis XI and Charles the Bold, nor had there been two centuries earlier when the integrating movement began. The theory of the Holy Roman Empire was no longer a ruling ideal, and there was neither the statesmanship to formulate a new plan of universal government, nor the generalship and the resources to carry one out. Nor could any Charlemagne have filled a place requiring so much inventive genius: the real Charlemagne had stood only for an old ideal which had been worked out through the ages. Now, under these circumstances, it was but natural that men should prefer to stand by their old local sovereigns when conflicts took place; and so, after numerous conflicts, national lines became pretty definitely drawn, and local sovereigns were able to apply to their own realms the theories of unity which had all along been held of Europe as a whole.

Therefore, we find national states arising at the very time when it seemed that the ideals of a unified Christendom were nearest of realization. The general histories treat so completely the political movements which resulted in the formation of the modern states that little need be said here except with reference to the bearing of this new political movement on the ethical and economic development. This bearing has already been indicated in so far as the development of the communes and the displacement of the embryonic commercial state were concerned.

We have already seen that political and economic conditions were such that Italy could not achieve national consolidation; and 
that the lingering feudal struggles in Germany resulted in the maintenance of a decaying feudal hierarchy, on the one hand, and the rise of the commercial cities which assumed all the powers of sovereignty, on the other. The Norman kingdom in Apulia and Sicily was the first national state to arise; but this was so far removed from the real life of Europe that it may be ignored here. A brief account of the rise of the great states and of the later course of events in Germany will be sufficient for our purposes.

In France feudalism had triumphed at Senlis in 987 ; but in giving the royal power to the Capetiens it established a dynasty which was to found a monarchy more absolute than the Carolingians ever dreamed of. For this house, starting with extensive and tolerably well-organized domains, usually represented by crafty and ambitious men, throwing itself at first in line with the feudal development and later allying itself with the industrial forces, consistently built up its power and turned its suzerainty into sovereignty, until it had developed a self-centered absolutism which only the Revolution could overthrow. The real beginning of the monarchy was made in the early part of the twelfth century, when Louis VI reduced his own little duchy, comprising the Isle of France, Orleans, and a few neighboring estates, to complete subjection, practically upronting feudalism. ${ }^{\text {I }}$ Philip Augustus added to his territorial possessions until his power was vastly greater than that of his neighbors, ${ }^{2}$ and everywhere established the principle of absolute and hereditary monarchy begun by Louis le Gros. This monarch won Normandy, Anjou, and Poitou from the Angevins, and by allying himself with the Albigensian Crusade he was able to extend his power to southern France. Philip's administrative reforms, whereby the important political functions were taken from hereditary barons and vested in an official class, enabled the monarchy to withstand the disorders of the minority of Louis IX, and made possible the establishment by that ruler of a government even stronger than that of his grandfather. Louis XI, perhaps the shrewdest

I Luchaire, op. cit., II, 298. The Capetiens also possessed numerous scattered estates in various parts of France, but the compact territory was the important part.

2 Ibid., 255 . 
of his race, practically completed the unification of France and definitely began to foster the national industries. By his death (1483), the great houses of Burgundy, Anjou, Bourbon, and Orleans which stood for the old order had been overthrown, and France had developed into a modern state. The national policy reached its culmination under Louis XIV, with the destruction of the last feudal castle by Richelieu (I626), and in the mercantile policy of Colbert (1662-83), which swept away the last vestiges of the independence of the commercial commune.

The English monarchy was pretty strongly established by the Conqueror; but feudalism revived under Stephen, and was not overthrown until Bosworth Field (I488), after the mutual destruction of the barons had been accomplished by the Wars of the Roses. Henry VII found his power resting upon the good-will of the commercial classes whose prosperity had been increasing during the entire period of dynastic disturbance. ${ }^{\mathrm{I}} \mathrm{He}$ found himself in a position to stimulate industries, especially the manufacture of cloth which had been growing steadily since the time of Edward III, but which had never yet been able to compete successfully with wool-growing and other agricultural pursuits. Encouragement was likewise given to English merchants to engage in foreign commerce; and thus the way was prepared for the great commercial and maritime operations of the Elizabethan Age. The English mercantile policy reached its culmination in the Navigation Acts of Cromwell (I65I, I660), ${ }^{2}$ the contemporary of the great French mercantilist; and the wars with the Netherlands, which followed these acts, gave England an advantage over that great commercial nation which was never afterward lost; 3 while the War of the Spanish Succession (I702-I3) laid the foundation of England's colonial empire and established her naval supremacy. 4

× Rogers, Six Centuries of Work and Wages, 332-34.

${ }^{2} \mathrm{Of}$ course, the second of these acts was after Cromwell's time, since he died in 1658 , but the policy was his, and the second act was but a continuation of the first.

3 Cf. Seeley, Expansion of England, 86.

4 Ibid., 32 ff. 
The unification of Spain was accomplished through the efforts of the Christians to throw off the Moorish yoke. The national feelings aroused by this achievement account for the appropriation of the civilization and industries built up by the Moors and the eagerness with which voyages of discovery were undertaken when the old route to the East was cut off by the Turkish victories. Portugal preceded Spain in maritime enterprises. Assured of independence of Castile, John I turned his attention to Africa. Ceuta was taken in I4I5. A naval academy was established to further voyages of discovery. Pope Martin V granted him the right of conquest from the Canaries to the Indies. Before the middle of the fifteenth century a trade in gold and negroes from Africa brought enormous wealth to the Portuguese; and before the end of the century the discovery of the sea route to India enabled them to build up a monopolistic trade in oriental wares, spices, and gems. But the Spanish operations in America soon overshadowed those of Portugal, and the precious metals which flowed in from Mexico and Peru not only made Spain the wealthiest country of Europe, but transformed the life of Europe itself. In the sixteenth century the total volume of money in Europe was increased more than fourfold. ${ }^{x}$ Aside from the advantages of the new commerce in luxuries and in commodities which had been luxuries, but which were now passing into general consumption, ${ }^{2}$ these large importations of precious metals gave Spain resources for the maintenance of standing armies and fleets, and wealth with which to secure any of the products of Europe. Under these circumstances, it was not strange that money came to be regarded as the chief source of national power. It seemed desirable to secure as much gold and silver as possible and to prevent it from passing out of the country by artificially maintaining a favorable balance of trade. Charles $\mathrm{V}$ was the original mercantilist, 3 the founder of the restrictive system, and

I Pigeonneau, op. cit., II, I6. Cf. Schanz, op. cit., I, 482-85.

2 The ability to buy without producing was, in the long run, a disadvantage to Spain, for national industries were not built up as in other countries.

3 That is, in the sense that mercantilism was adopted as a thoroughgoing 
gave the cue to all Europe. The policy of isolated development seemed to be the way to national greatness. While, therefore, other nations had their beginnings earlier, Spain was the first to reach the ideal which all had set before them, and set the pace for Europe in bringing a national economy to the assistance of the political forces which were making for national life.

The Netherlands achieved national independence through the struggle for existence against Spanish oppression. The towns and provinces retained much of their local independence; but even the Burgundian administration had done much for the economic unity of the country, and the eighty years' struggle for independence necessitated a centralized policy. It is sometimes said that the Dutch never adopted the mercantilist policy. In a certain sense this is true; for, having devoted themselves to a few specialized manufactures and having come to depend largely on their world-wide trade, it was never to their interest to maintain a "favorable balance of trade." Yet no other nation more consistently used political power for commercial ends. The colonial policy, the navigation policy, the fisheries were strictly regulated by the central power. A strict monopoly was maintained in the East Indian empire which had been wrested from the Portuguese; the tolls imposed at the mouth of the Rhine put the trade of that river in Dutch hands; naval preponderance in the Baltic was taken advantage of to control trade; the German foreign trade was almost monopolized by the Dutch, and remained dependent upon them till the middle of the eighteenth century. During the entire period of their national greatness, they were carrying on wars for commercial ends. In the truest sense of the word, no other nation so completely carried out the mercantilist policy. The Dutch were not lacking in patriotism, in national spirit and love of country; but the Netherlands remained a large commercial community and used political power to further economic ends. The chief characteristic of the other states was the pre-eminence of political interests; but even with them political policy had to

policy. Restrictive regulations had been made as early as the fourteenth century by Florence, England, France, and other countries. 
conform in general to economic requirements, and after political unity had been firmly established the activities of these states were largely directed to the development of national wealth. The predominance of the commercial spirit in the Netherlands was probably due in part to the absence of a monarch, in part to the commercial development of the provinces before they were united in one nation.

The tendency in those sections which did not form themselves into national states is thus stated by Schmoller:

The greater cities sought to widen themselves into territorial states by the acquisition of villages, estates, lordships, and country towns. In this the great Italian communes succeeded completely, certain Swiss towns and German imperial cities at least in part. . . . . In Germany, however, it was, as a rule, the territorial princedom, founded on the primitive association of the tribe, and resting on the corporate estates of communes and knights, which created the new political unit-a unit which had for its characterstic the association of town and country. .... During the period from the fifteenth to the eighteenth century, these territories, in constant struggle with other institutions, grew not only into political, but also into economic, bodies. . . . Territorial institutions now became the main matters of importance, just as municipal had been; like them, they found a center round which to gravitate; and they sought to shut themselves off from the outer world, and to harmonize and consolidate their forces at home. And thus arose an inclosed territorial area of production and consumption, a territorial system of measures and weights and currency -an independent territorial economic body which had its own center of gravity, was conscious of it, and acted as a unit in accordance therewith. ${ }^{\mathrm{x}}$

Schmoller's conclusion from the facts found in Germany that the "territorial" stage was a necessary and universal one between the municipal and the national stages is as unwarranted as his assumption of a universal free-mark system. This territorial organization was found only in Germany. That which approached it in Italy, in some parts of France, and in the Low Countries scarcely resembled the conditions described at all. Commonly, if not universally, the commercial cities in the days of their independence controlled more or less extensive agricultural lands in the neighborhood. This was true of the German cities before

× Mercantile System, 13, I4. 
the change described by Schmoller. These so-called territories were nothing more nor less than petty national states, founded on the basis of the ancient princedom. They differed in no respect from the great states, except that there was no prince strong enough to consolidate a number of them into one of respectable size and large resources. The general policy of harmonizing diverse interests and of promoting the economic interests of the whole community was the same as that of the larger states. In no case did the territorial grow out of the urban organization, except where a city maintained its old independence and controlled a small agricultural environment; for example, Lübeck and Hamburg.

There were several reasons for the failure of Germany to develop a unified political organization. One of the chief of these was the decay of German commerce, beginning with the loss of the Russian and English trade and accelerated by the rise of the new maritime powers on the Atlantic, whose trade soon surpassed that of the Baltic in importance. The ruin was completed when Holland, Denmark, Sweden, and Poland gained control of the mouths of all the German rivers and dominated the entire trade of the Baltic and the North Sea. The cities, weakened by the loss of prosperity, fell an easy prey to the territorial lords who had been too feeble to be considered an important factor in the days of commercial greatness. These lords were assisted in bringing the cities under their authority by the country population which had been treated with scant consideration by the merchant burghers. The great increase in the non-agricultural population and the growing dependence on the neighborhood for food meant greater prosperity for the country people and, consequently, greater power for the landed proprietors. The power of the latter could be asserted as that of the cities began to wane. Then, too, the lower craftsmen had been so harshly treated by the rulers of the cities that they were very ready to see the power pass into other hands.

The inconvenience of many systems of money, weights, and measures, and of inadequate police in general, brought the 
cities to realize the advantages of territorial government, even when the latter could introduce uniformity into but a comparatively small area. The imperial power was unable to co-ordinate conflicting systems except in the southwest. Uniformity was introduced gradually within limited areas; and the currency system for a whole principality drew a "circle which bound the territory into one economic body."

The traditions of the Empire and the imperial constitution, imperfect though the latter was, had much to do in arresting the growth of large German states. There was always a strong tendency to form the new states on old territorial lines, and many of them were so small that a purely local policy was all that was required. In the northeast there were large areas, but these were sparsely populated and were in a backward economic condition. With all the ruin wrought by the Thirty Years' War, there was perhaps a gain in the political readjustments which it necessitated.

Thus we see that while states were formed in Germany in much the same manner as elsewhere, the political development was arrested because the political areas were too circumscribed to have either national power or a beneficial national-economy. To secure both of these some of the stronger and shrewder princes began to make scattered possessions contiguous by purchasing or conquering intervening territories. But this was a long process, extending in the case of Prussia from the detachment of the Brandenburg towns from the Hanseatic League and the abolition of their right to contract independent alliances (I448-88) to the death of Frederick the Great (1786). The South German states had a more rapid development, but none was able to attain the position of respectable nationality until after the end of the Middle Ages. The economic degeneration caused by the religious wars would have prevented national development, even had the

I Schmoller attributes to this cause alone the formation of the territorial unit. He seems to overlook the important economic changes which were the real determining causes. Of course after the new unit was formed, the fiscal and currency systems would have much to do in shaping its policy and preserving its integrity. Cf. Mercantile System, 33-43. 
political conditions been more favorable. Germany must be regarded as in a state of arrested development both politically and economically at the time when northern Europe was emerging into the modern period. ${ }^{x}$

So Europe emerged from the great transition of the Middle Ages broken up into numerous national states, each pursuing its own selfish policy, all having definitely abandoned the old ideal of a unified Christendom which had so long held society together. And this condition was found at the very time when the ideal seemed nearest of realization. The economic means had been found for an integration of society such as had never been known before. Industry had approached that normal condition which we have all along held to be precedent to the realization of the ideal of an organic society, wherein the interests of the individual and of the whole should be identical. This normal functioning of the individual for the whole had not yet been fully attained, but the point had been reached at which each important section was functioning for all other sections. There were no longer any self-sufficient communities. Every community was producing goods which supplied a world-demand, and everyone was depending for the satisfaction of its wants upon industrial activities which were going on in all parts of the world.

At this very point there was inaugurated the narrowest conceivable policy, mercantilism. In general, it was held that a nation should produce everything needed for consumption or bring it from its own colonies, and that any transaction that could benefit one community must be disadvantageous to another. While it was practically impossible to make national policy conform absolutely to this ideal, statesmen endeavored to approach it as nearly as possible. Artificial stimuli were given to many unprofitable industries, and commercial wars and customs reprisals were undertaken to destroy rivals. Since complete commercial independence could not be maintained, a favorable balance of trade had to be secured; for it was thought that a balance of the

I For an admirable sketch of the development of Prussia, vide Schmoller, Mercantile System, passim. 
overreachings of trade would thus be credited to the exporting nation and a surplus of gold and silver obtained at the same time.

On the whole, however, this movement was not so serious an obstruction to the course of social development as it appears to be on the surface. The reasons why the single economic community could not evolve a political structure have already been indicated. These were sufficient excuse for the national movement. A world-wide political organization being out of the question, the division into states was the best arrangement possible. The existence of the national state being justified, the mercantile policy, which was simply the policy of state-making, was both wise and necessary. Nor can it be said that the national policy was any more selfish than the municipal policy had been. It was simply more effective because the sphere to be developed was larger and the power available for coercion greater. The older interdependence of different communities could be modified because the division of labor within the wide national area could be made so much more complete than was possible within any municipality. In spite of customs restrictions, there was free commercial intercourse within an area that was wide for the times. The relative economic independence of given areas was the foundation for a peaceful community of great states.

Further, it can not be doubted that a gain was made when the State as an end of economic activity was substituted for an economic activity which had only possessive wealth for its end. The sovereign became a high constable who secured approximate justice for all classes of subjects; whereas the ruling merchants had ignored the interests of all classes save their own. The interest of the sovereign was not in wealth, but in national power; but the two were regarded as reciprocally related, and the king ordinarily had no interest in favoring one class of subjects rather than another. The caprice of the monarch and the rapacity of his courtiers frequently caused much suffering; but this was incidental to absolute monarchy and usually affected the rich and powerful rather than the masses. In general, the good-will of the masses was sought by the rulers. It has even been held by some 
writers $^{x}$ that these national states were democratic; but it is an unusual use of the term to apply to it a deference to public opinion such as is found under the Russian autocracy.

As this political system secured substantial, even if uncertain, gains for the industrial population, so also it eventually increased the solidarity of Europe which it seemed at first to destroy. A great deal of friction was inevitable while national industries were being established and the transoceanic countries were being divided; yet many of the liberal practices inaugurated by the enlightened selfishness of the commercial cities were kept up. And while the feeling of community which had been created by the Church and the Empire was lost, Europe soon began to seek some other bond of union. On the political side this was found in the beginnings of the Law of Nations; and the development of its code and the strengthening of its sanctions have marked the growth of feeling of community among civilized nations, parallel with the development of a genuine functional unity wrought by the industrial activities of civilized peoples and surpassing in effectiveness the mystical sense of solidarity with which mediæval Europe began. But this is a subject which will demand our attention in the next chapter.

×. g., Burgess, Political Science and Constitutional Law, I, 126, 127, and elsewhere. 


\section{CHAPTER V}

\section{THE END OF THE MIDDLE AGES}

The development traced in the last chapter brings us to the close of the Middle Ages. No definite line can be drawn between mediæval and modern times. The fall of Constantinople is even more arbitrarily chosen to mark the close, than the fall of Rome to mark the beginning, of the great transition period; for the dispersion of learned men with their manuscripts could have had no influence on the thought of Europe, had not the consciousness of the newly made society stimulated a romantic interest in the beauty of classical literature. This literature, which the degenerate remnant of a great race had ceased to appreciate in any vital sense, simply served as an objectification of the consciousness of the new life which was springing up in Europe. Had that means of objectification not been furnished, while the awakening might have been delayed, it would nevertheless have found other means of expression. The Renaissance was a movement from within the vigorous society of western Europe, not the result of the missionary effort by wandering Greek teachers.

The consummation of the mediæval movement was the attainment of economic interdependence and the formation of political organizations more in harmony with such an economic condition than the feudal system and the Holy Roman Empire could be.

The modern period did not properly begin until the democratic movement and the Industrial Revolution began. There was, therefore, a long period, extending from the fall of Constantinople to the last quarter of the eighteenth century, corresponding to the period just preceding the final overthrow of the Roman Empire. During this period, established institutions and habits of thought were battling with the progressive movement, and the various elements of the new society were coming into equilibrium. Some of the events of this period have been anticipated in the last 
chapter in the discussion of the methods by which a community of commercial nations was established. We found that Europe emerged from the Middle Ages a truly organic society, in which a very complete economic interdependence was established through commerce, though the latter was not wholly free from political interference nor wholly freed from the effects of a proportionately large trade in luxuries. The old ethical bond which had served to hold together the innumerable economically independent groups had been destroyed. The individuals of this society could have a functional relationship with the whole, instead of being bound to it simply through the emotional consciousness developed by the teaching of the Church and maintained by the magical mediation provided by that institution; but the conscious individuality was not yet fully developed, because the individual's activity was still regulated by the gild or other local institutions. The modern period did not fully open until at least the beginnings of an international code and a humanitarian philosophy had been made. This involved the sweeping-away of the authority of the Church and the abolition of status and the restrictions of the gilds.

During this period which was only beginning to be modern, a number of important events took place. There was the Reformation whereby the authority of the Church was permanently broken-to a considerable extent, even in those countries which remained most Catholic-and it became necessary to find new sanctions for the guidance of life. The artisan was emancipated from the regulation of the gilds and status was broken in all sections of society. Consequently, there was a growing sense of individuality, which finally produced the democratic movement. The transoceanic lands were appropriated by Europe; and commercial and colonial wars, lasting from 1600 to 1800 , determined the relative positions of the new nations. The great problems that were raised for Europe during this period were: the destruction of ecclesiastical authority, the removal of international friction, and the freeing of the activity of the individual. 


\section{THE REFORMATION IN RELIGION}

The destruction of the authority of the Church and the development of the democratic tendency were closely interrelated movements, though many features of each were independent of the other. The real problem which was being solved by these conflicts was the one which has been seen to run through the whole mediæval period, namely, the relation of the particular to the universal. We have already seen that, at the time when Europe was beginning to get control of the economic means by which the ethical ideals of Christendom were to be realized, the importance of the universal was given definite statement by Anselm, and that the Church suppressed the opposing nominalistic theory which expressed the growing appreciation of the particular that was being used. The universals were then all-important for the development of civilization, and were so recognized even by the nominalists themselves.

Now, by holding before Europe the ideals which had come from the past, the Church had started a movement that was bound to bring the particular facts of life into greater importance. Further, while not consciously recognizing the possibility of social reconstruction in this life, the Church had set the example and had led in the development of the economic means by which the social ideals were to be realized; that is, in the employment of the particulars which in time would exhaust the universals with which the institution was identified. This movement, however, began to go beyond the bounds anticipated by the Church. That institution was prepared neither to surrender the authority which grew out of the striving after the ideals that barbarian society had received from antiquity, nor to countenance the practices which the expansion of industrial activity necessitated. Therefore, at the very moment when the authority of the universals was slipping away, realism was given its most definite expression; and when the needs of commerce were revolutionizing economic practices, the earlier mediæval theory regarding prices, usury, etc., was most positively stated by the canonists and other ecclesiastical authorities. The philosophical statement of social 
relations and the summary of the rules for the government of economic relations were made by Thomas Aquinas in the latter half of the thirteenth century. His works reflect the actual conditions of a period which was then passing away; and the ecclesiastical institution, which was predominant during that period, has held the Summa theologice as its official philosophy down to the present day.

Following Aristotle, whose Organon had by this time been fully absorbed by Scholasticism, Aquinas accepts the State as a necessary institution of social life. In this he differs from Augustin who regarded it as a consequence of the Fall. With Aquinas, man is adapted to the State by nature, but his higher destiny is the salvation which can be secured only in the community of the Church. "As the higher everywhere realizes itself through the lower, and the lower exists for the higher, the political community is to be the preparation for that higher community of the State of God. Thus the State becomes subordinate to the Church as the means to the end, as the preparatory to the complete." Here was a recognition of the development of the new society coupled with an insistence that the true social condition was still to be realized only in the New Jerusalem.

But this harmonious relation between Church and State was already broken. The spirit of the Middle Ages had refused to accept a dualism as final. The conflicts between Empire and Papacy would occasionally produce a practical dualism, but in theory a unity of Church and State was always held, and the unity was found in the Church rather than the State. Mankind was regarded as a single community whose head was God; and while the emperor might contest the claim of the pope to temporal as well as spiritual vice-regency, yet, on the whole, from the time of Gregory VII, the Church made good its claim. ${ }^{2}$ Now, how-

I Windelband, History of Philosophy, 327 .

2 On the subject of the unity of the Church and State, vide Gierke, Polttical Theories of the Middle Age, 9-2r. This admirable treatise, a translation by Maitland of a small section of the author's work Das deutsche Genossenschaftsrecht, presents a very complete statement of the political theories of the later Middle Ages. One could wish that the author had traced the historical develop- 
ever, the highest position that could be accorded to the Church by the political power was one of equality; and this co-ordinate position claimed for the State was no longer weakened ${ }^{x}$ by the admission that the Church, because occupying itself with higher duties, could assume the headship when necessity demanded; as the higher feudal lord, who usually left his vassal to his own devices, could interfere when the vassal was derelict in the performance of duty. At the very time when Thomas was giving definite expression to the claims of the Church, Dante was proceeding from the same conception of the place of man in the State and giving expression to the spirit of the Renaissance. ${ }^{2}$

With Dante the relation of subordination [of State to Church] is already changed for that of co-ordination. The poet shares with the metaphysician the thought that because man's destined end is to be attained only in the race; this makes a perfect unity in political organization requisite. Both demand the universal state, the monarchia, and see in the Empire the fulfilment of this postulate. But the great Ghibelline can not think theocratically, as does the Dominican monk; and where the latter assigns to the imperium the place of subordination beneath the sacerdotium, the former sets the two over against each other as powers of like authority. God has destined man for earthly and for heavenly happiness in like measure: to the former he is conducted by the State, by the natural knowledge of philosophy; to the latter he is guided by the Church, by means of revelation. In this co-ordination the joy of the world, characteristic of the Renaissance, bursts forth as victoriously as does the feeling of strength which belongs to the secular state. ${ }^{3}$

Now when a position of co-ordinate importance is given to the Church, its authority is virtually denied; for this theory involves an assertion of the present importance of earthly society, and turns over to the Church only the regulation of that future life which was steadily losing its hold on the active interests of men. However, it was fortunate that the development proceeded along ment of the various theories he discusses, instead of giving them without reference to their setting. Most of his authorities belong to the period with which we are now dealing, when the rise of the State was causing men to -question the pretensions of the Church.

I As had been done by the boldest of the adherents of the emperor in earlier disputes.

2 De monarchia, written sometime about $\mathrm{r} 300$. Thomas died 1274 .

3 Windelband, op. cit., 327. 
the lines suggested by Dante, for society was not yet prepared to ignore the bonds furnished by the Church. Until commercial interdependence was further advanced and men were brought to a sense of the solidarity of Europe through the activities of daily life, the abandonment of the ecclesiastical bond would have meant an indifference to the larger social integration sought by the Christian consciousness. This was the state of affairs in southern France and southern Italy, where all external conditions seemed most to favor the Renaissance. In southern France the premature reformation of the Waldenses and the Albigenses, on the one hand, and the wide acceptance of Averroism spread by Jews and Arabs alike, on the other, practically detached society from the Church and Christianity; and in Sicily the blending of Byzantines, Arabs, and Normans under the liberal, if not atheistic, Frederick II resulted in a civilization having as little connection with the rest of Christendom as its head had sympathy with the temporal power of the pope. ${ }^{x}$ The real Renaissance was saved from the dilettantism of these earlier movements by a nominal adherence to the Church. It is true that the men of the fifteenth and sixteenth centuries became indifferent toward religious beliefs and philosophical subtleties; but by that time the commercial and political developments and the humanistic philosophy rendered the ecclesiastical bonds less necessary, and European society could maintain the essential features of unity at the same time that it divided itself into the various independent nations.

The economics of the Church.-Before tracing farther the development of the new philosonhy, it is necessary to notice the economic policy of the Church-also best expressed in the writings of Aquinas. This policy was chiefly concerned with two economic phenomena, prices and interest; and was intended to combat one of the seven deadly sins, avarice. The Fathers had added to the natural institutions of the Roman jurists, namely marriage and the nurture of children, the institutions of community of goods and personal liberty. Private property was regarded as contrary to the gospel. Trade and private property were

${ }^{x}$ Gebhart, op. cit., 14-18, 194-200. 
allowed to the laity grudgingly, just as slavery also was permitted, because of the hardness of men's hearts. Since the Church had to deal chiefly with nobles who acquired wealth in other ways than by trade, the regulations were doubtless of considerable value. These regulations were found in Canon Law, and were given elaboration and exposition in the fifteenth century; ${ }^{\mathbf{x}}$ but the doctrines regarding prices and usury were given a final statement by Thomas Aquinas at the time when trade was increasing and the doctrines of the fundamental right of private property and of freedom of contract-both wholly non-Teutonic and nonChristian-were being drawn from Roman Law by the thousands who went to Bologna for light on political and economic problems.

The doctrine of justum pretium asserted that no more should be asked for an article than it is worth-that is, than it had cost - the value of producers' and traders' services being determined by what was suitable for their respective stations in life. The rule was intended to check the avarice of the seller, not to protect the buyer, though an overexaction on the part of a landlord was condemned both as avaricious and unjust. The rule had no reference to too low prices, for competition was not operative except in such remote degree as to be imperceptible at the time. Since capital played a very subordinate part in production, and since most articles were produced near the market, the status of the producer could be known and prices could be regulated by public opinion. This doctrine presupposes a narrow community, within which exchange was to take place, and a definite social order, in which every individual had his appropriate status. So

I The best discussion of the rules of the Church is given in Ashley's chapter on "The Canonist Doctrine," at the close of the second volume of his English Economic History. I wholly accept his view that the policy of the Church was originally well adapted to economic conditions, and that the evasions of the law were the result of commercial ingenuity, not of suggestions made by ecclesiastical casuists. But it seems to me that the author does not sufficiently recognize the tendency of the Church to maintain its old position in the face of economic progress. The Church gave way gradually, but the writers of the earlier commercial period, such as Aquinas, show a disposition to hold on to as much as possible, not to save the poor from extortion, but to withstand what seemed to be a general demoralization of society. 
long as the actual social conditions corresponded to this presupposition, the regulations were beneficial; but when goods were exchanged between distant communities and when new opportunities were constantly stimulating men to new activities, it was possible neither to know the conditions of production nor to maintain status. The necessities of trade and the strength of the associations of merchants and artisans rendered the Church impotent. Attempts were later made to revive the doctrine, but the barriers once broken down could never be raised again.

Closely connected with the doctrine of fair price was the prohibition of usury. The saying of Aristotle, "Money itself is barren," was accepted, and rightly, for capital did not exist in the earlier Middle Ages. Money was borrowed for unproductive purposes; and the fact that it was loaned was evidence both that it could be spared by its owner and that security was given for its return. Neither the knight who pawned his castle to raise funds for a crusade, nor the poor man who borrowed to tide him over a period of bad harvests, could employ the borrowed wealth in such a way as to produce a profit. Therefore, the attitude taken by the Church was in the interest of the needy. A canon of II79 excluded usurers from the privileges of the Church; and spiritual penalties proving insufficient in the thirteenth century, the wills of unrepentant usurers were declared invalid by the ecclesiastical courts under whose jurisdiction they came, and other severe penalties were enacted. The secular courts co-operated with the ecclesiastical in attempting to put down the odious practice. Aquinas reaffirms the position of the Church and denies that money can be put to productive purposes. ${ }^{x}$

But by the latter part of the thirteenth century the accumulation of wealth, the extension of commerce, the opportunity of investment of capital in ships and cargoes, rendered interest entirely unavoidable. If profit was obtainable by investment there seemed no good reason why the owner of loanable funds should not obtain a portion of the profit which the borrower could

× E. g., in Summa theologia, question 78 , he holds that money is simply a medium of exchange which, when spent, is totally consumed. 
secure only with the assistance of the capital. This sanction of common-sense was strengthened by the discovery that Roman Law regarded a contract to pay interest as entirely legitimate. Accordingly, devices were adopted by borrowers and lenders by which free capital could be placed where it was most needed, and yet without violating the letter of the law. The simplest of these devices was partnership. A capitalist who did not care to make a voyage could enter into partnership with a captain or traveling merchant, providing all of the capital, risking all that he thus invested, and receiving a part of the profits. If, as was frequently the case, the man who made the voyage furnished half of the capital, he ceased to be an employee of the home-staying capitalist, becoming the director of the enterprise himself and paying a smaller proportion of the total profits for the use of the borrowed capital. So long as the lender shared the risks and did not receive a stipulated percentage on the loan, the Church justified this practice. Another plan by which profits could be obtained on loans was that of lending gratuitously for a nominal period"days of grace"-and then charging a penalty for damnum emergens-damage because of inability to use the money at the time the agreement called for its return-or for lucrum cessansloss of profit that might have been derived from use of the capital, had it been returned at the stipulated time. The Church held that the loss by the creditor should be proved, and that the amount of damages to be paid to him should not be agreed upon beforehand, Aquinas even holding that the chances of loss of the whole principal were greater than the possibility of gain by its use, were it returned at the stipulated time. By the fifteenth century, however, it was held that proof could be dispensed with in the case of merchants and traders, and it was even permitted that a fixed rate of interest could be agreed upon. The third method by which interest could be obtained on loans was by the purchase of rent-charges. A person who was in receipt of rents could agree to give these rents to another for the use of capital loaned by the latter; and, later, it was found possible to sell a rent-charge which had not existed before. No objection was made to the practice 
until it was carried to excess, when laws were enacted to provide for the redemption of the estates by the return to the creditor of a sum aggregating the annual payments of a certain number of years, as ten, twelve, or twenty. This amounted to a recognition of the legitimacy of mortgage loans at specified rates of interest. In all of these cases the Church so far receded from its earlier position as to permit interest in all transactions where loans were contracted for purposes of trade, the prohibitions that still held good applying only to non-commercial loans. The purpose of the Church, however, was not so much the protection of the poor borrowers, as the preservation of its own consistency, where exceptions had to be recognized, and opposition to the growing avarice, where resistance was kept up.

While Thomas Aquinas and the Canonists stood for the ancient economic doctrine on the questions just mentioned, they had been sufficiently influenced by the progress of events to depart from the earlier view that the use of all property should be common to all men. Thomas justified private property because private ownership secured the best care and the most productive employment-very worldly considerations-and because ownership had a good effect on character; but he held that it was justifiable only when used for the common good. As regards the amount of property that might be owned, he again emphasized the statical social order, by holding that it should be only such as was suitable for one's station in life. This institution, then, like the State, was allowed a position which Augustin would never have recognized, but it was still to be wholly subordinate to the ends set by the Church.

The stand taken by the Church through Aquinas for the maintenance of an established economic order subordinate to the ethical purposes for which the Church stood was as ineffectual as that taken for the subordination of the political order. As the growing political powers could not recognize the latter, so the economic institutions could not be bound by the former. For a time business would try to adapt itself to the accepted moral standards; for a time the Church attempted to save the essential principles 
while permitting numerous exceptions and tolerating much casuistry; but in the end the economic practices were worked out without reference to ecclesiastical rules. As soon as spiritual penalties proved insufficient, we have evidence that the power of the Church was waning. Possessive wealth had become an end in itself, and the authority of the Church was relegated to the less vital sphere of spiritual things. Whatever remnants of status were maintained by the gilds and the secular laws were incidental to processes not yet fully developed, and were wholly independent of the policy of the Church. The commercial development had rendered forever impossible the maintenance of a statical order with which men had to remain content until they should enter the ideal society of the other world. There was no longer any station of life which could be held as necessary for any man; consequently, his activity could not be regulated by fixed rules. Individuals were coming into normal relations with society through the development of commerce; and while the individual did not freely function for the whole, the ideal was so far realized that the Church was no longer needed to mediate between the individual and the ideal whole. This was the cause of the decay of ecclesiastical authority.

The new nominalism.-The individualism which was implied in Augustin's position and which the Church had always encouraged on the emotional side, was now being expressed in the daily activities of men in organic relations with one another. Individuality was becoming actual. It could no longer be pushed off into the future life. This growing individualism was given philosophical expression in a new nominalism which, unlike that of the eleventh century, was much more than a recognition of the fact that the particulars were being used: it was also an assertion that the universals had been exhausted. This position was not possible in the time of Thomas Aquinas, but by the end of the fourteenth century the development had proceeded so far that it was the express contention of the opponents of the old order. William of Occam, although ranging himself on the side of Dante's imperium as against Aquinas' sacerdotum, was no longer able to 
accept the realistic conception of the human race as a whole bound together for the realization of one end. "The nominalist sees as a substantial background in social and historical life only the individuals who will, and he regards State and society as products of interests (bonum commune). In theory, as in life, individualism prevails." Here was the beginning of a "contrat" theory. Indeed, Occam and Marsilius of Padua explicitly taught that the title to all rulership lies in the voluntary and contractual submission of the ruled; ${ }^{2}$ and this was urged against the temporal pretensions of the pope, rather than against political rulers. The practical application of this theory, however, could not be made until the movement toward national statehood was accomplished. A significant feature of these discussions was their definite secularization. Thenceforth they could be carried on without reference to ecclesiastical claims or supramundane interests. The purely empirical, non-theological consideration of social relations was begun by Nicholas Oresme (d. 1382$).^{3}$

Thus, we see, the authority of the Church was very generally set aside, except in so far as it could be artificially maintained by the powerful organization which had been the natural development of an earlier period. The more orderly social life and the increasing command over nature destroyed its magical power; and its moral power-its possession of ideals upon which society depended for its very life-was destroyed by the exhaustion of those ideals and the tendency to make either the political organization or possessive wealth the end of social activity. In proportion as men are interested in the supernatural, the power of the Church is great. The control of the physical and social environment means a lessening of belief in the supernatural. The interest in the future life is never entirely lost, but it is largely suspended when present activities and earthly ends become of pressing

I Windelband, op. cit., 328.

2 Gierke, op. cit., 39, 40.

3 For his tract on "Money," vide Cunningham, Growth of English Commerce and Industry, I, Appendix. 
importance. The breakdown of Church authority was caused by the greater control of nature, the more orderly social conditions, and the absorbing interest which came to be taken in earthly pursuits. Neither the Reformation nor the Counter-Reformation could restore that authority, though, of course, the various religious organizations which have existed since that period have had an important place in the world, both in satisfying the remaining interest in the future world and in stimulating the moral motives of men.

\section{THE BEGINNINGS OF MODERN THOUGHT}

One of the chief causes of the revolt against ecclesiastical effect authority was the new method of thought which was necessitated by the changed social conditions. A phase of this new thought has already been discussed as a part of the changed view of the Church; but philosophy was now wider than theology, and much that had to do with social development had nothing to do with religious and ecclesiastical problems. The human mind, having been stimulated to activity by the Church, and then emancipated from ecclesiastical authority, naturally cast about for some means by which to express the expanding consciousness. This was found in classical literature which was first made available through the Arabians and the discoveries in Italy and later through the dispersion of Byzantine scholars by the conquests of the Turks. This movement was due to the passionate, though vague, search for novelty which the oldest products of human thought here chanced to satisfy; to the appeal which Greek literature could make to minds already stimulated to seek the beautiful by the developments of a rich civilization; to the necessities of municipal reconstruction in Italy which aroused an interest in Roman literature; and to the sanctions furnished by this literature for political and individualistic developments and for skepticism in religion. It was easier to find in the classical literature an objectification of the new spirit, than to work out an entirely original expression of that spirit. So, the Renaissance was charaterized by a return to the past as an advance upon the present. 
In Italy an indifferentism prevailed as regards religion, while the formal religious rites were still tolerated; but in Germany, where the religious sentiment was still strong, and in a somewhat less intense form in the other northern countries, a reformation of the Church was attempted by a return to earlier traditions. The doctrines formulated by Aquinas, to which the Church absolutely committed itself at the Council of Trent (1563) and for the defense of which the Society of Jesus was formed, were set aside by the reformers for the simpler expression of the relation of the individual to God found in the doctrines of Augustin, or for a humanistic theology derived from a blending of the Jewish writings and the Greek philosophy. As the men of the Renaissance fell back upon Plato or Aristotle, so the men of the Reformation fell back upon Augustin or a humanistic Christianity.

In every instance the movement represented a romantic interest in the ancient-the abandonment of mediæval forms and the return to Plato and Aristotle in philosophy and early Christianity in religion. The various philosophical and religious sects thus formed warred among themselves almost as much as against the Church itself. The theological development was arrested by the fixation of doctrine by national churches; and secular thought, becoming surfeited with the warfare between the transmitted doctrines of the past, turned to the cosmic life of nature for new inspiration. ${ }^{x}$

The continued search for novelty, coupled with the interest in the physical world aroused by the geographical discoveries, led to the study of nature; and the results attained by Kepler, Bruno, Galileo, and later by Newton, furnished the key for the opening of the genuinely modern method of thought. This took place most fruitfully in England, France, and the Netherlands, Italy having been smothered by the Counter-Reformation, Germany crippled by the religious wars, and Spain brought to a permanent intellectual stagnation by a religious despotism. This problem of method was attacked by Bacon, Hobbes, and Des Cartes in the earlier years of the seventeenth century.

$\therefore$ Windelband, op. cit., 348-66. 
The new method consisted essentially in a procedure from the particular to the universal, thus reversing that of the whole Middle Ages. It was a true reflection of the changed social conditions. The Humanistic movement in philosophy and the Reformation in religion had been caused by the exhaustion of the old universals; but the men of that period had not come to the point of completely revolutionizing their method. Dissatisfied with the mediæval tradition, they simply attempted to find more adequate ideals in still more ancient traditions. It was still felt that the best lay behind them. The seventeenth century, however, was marked by a radical change of method, and men began to proceed from actual facts to new generalizations. Bacon set his Novum organon over against the Aristotelian Organon, proposing an inductive method and pointing out the illusions (idola) to which adherence to various traditions and presuppositions subjects men. But Bacon was unable to state his method in detail, and was more or less encumbered by old habits of thought. On this account, the practical application which he attempted to give his philosophy-to secure dominion over the forces of nature for $\operatorname{man}^{x}$-became a mere fanciful portrayal of the wonders for which the excitement of the times led all men to hope.

Des Cartes was more successful in breaking away from the trammels of the past. He was

delighted with mathematics on account of the certainty and evidence of their demonstrations, and from the study of this branch of knowledge he passed to the consideration of general philosophical method. He demanded not only the induction of Bacon, but that the induction "should lead to a single principle of highest and absolute certainty, from which afterward, by the method of composition, the whole compass of experience must find its explanation. ... The first task of philosophy is analytic, the second synthetic. ${ }^{2}$

His aim was to obtain a system of self-evident axioms and postulates from which to determine the validity of particulars; but these axioms were not to be derived from universals, as had been

x His Instauratio magna bore the sub-title De regno hominis; and his Nova Atlantis was a utopia in which human life should be completely transformed by inventions and discoveries.

2 Windelband, op. cit., 390. 
the case in the past: the universals were cast aside, and the appeal was made to self-consciousness as a criterion for the particularnot to the universal consciousness, but to the consciousness of the individual. Every particular is true which is as clear and as immediate as the self-consciousness of the individual. The old world is done away, and that which is given in the new world to be is the center of individual consciousness. ${ }^{3}$ Des Cartes' interest was purely theoretical, and he never went so far as to seek to apply his method to nature or to society; nevertheless, he truly represented the spirit of the age in throwing off allegiance to tradition and in starting with the individual.

Hobbes, on the other hand, was so pressed upon by the stirring political events of his time that he was obliged to apply his method at once to the consideration of political problems-indeed, he had to work out his method in its very application. He was largely influenced by Bacon and his younger contemporary, Des Cartes, and even more directly by the physical theories of Galileo. He said he intended to deal, first, with physical nature, then with man, and then with the State; but he was driven to the third first, and was never able to return to the other two. $\mathrm{He}$ found the center of his social theory in the active individual. But this individual was a reacting individual and did not exist without the State. The State, however, was formed by the voluntary agreement of individuals who realized the advantages of co-operation. Absolute authority should be vested in the king as an impartial umpire; but this authority had no divine sanction; it was simply vested in one man by the agreement of self-seeking people who felt the need of external regulation. The agreement having been made to vest the authority in a single family, the king is justified in using that authority to prevent the breaking of the

I"I abandoned literary pursuits altogether, . . . . being resolved to seek no other knowledge than that which I was able to find within myself or in the great book of the world. . . . As for all the opinions which I had accepted up to that time, I was persuaded that I could do no better than to get rid of them at once, in order to replace them afterward with better ones, or perhaps with the same, if I should succeed in making them square with reason. . . . The first rule was never to receive anything as a truth which I did not clearly know to be such."-Discourse upon Method. 
contract, even though a revolt is caused by his own misgovernment. The Church is simply a part of the external machinery of authority. Hobbes thus came as near as possible to a justification of the claims of the Stuarts, but still held to the primary importance of the individual from whom all authority proceeds. The value was not in the whole, but in the individual.

Hobbes' interest, however, was not democratic: it was political rather than social. The phenomena of greatest importance at the time were the national state and the relations between states. The organization of the government and the establishment of international comity could not be explained or sanctioned on the basis of the old universals. The method which had to be employed was that of proceeding from the particular to the universal. It was only on the basis of the former that the latter could be explained. The democratic movement was advancing steadily through all this period, but it had not gained sufficient headway to compel attention to the rights of the individual as such. The men of the later Renaissance, so far as they went beyond an elaboration of method and a consideration of physical nature, were interested above all else in the political situation. It remained for the men of the Enlightenment to consider the welfare of the individual as such; and when they did, they used the same general method which their predecessors employed. During all this time, theology had to be left as it was, or ignored altogether. Its reconstruction, as well as the development of a general social philosophy, had to be left until the consideration of the particular facts of the physical and biological sciences had proceeded so far as to warrant generalizations which could be used in cosmic and social philosophy. This did not take place until the nineteenth century, and then not in a thoroughgoing way until Darwin had made his contribution.

\section{POLITICAL PHILOSOPHY}

The reason for the interest in political phenomena has already been stated. The authority of the Church had passed away. The State could accept neither the position of subordination 
assigned to it by Aquinas, nor that of co-ordination suggested by Dante. It had become the only authority. But its authority, in spite of the theories of absolutism held by many great statesmen, was an authority growing out of the necessities of industrial life and maintained for the preservation and furtherance of the interests of all classes of citizens. The sovereign power was essentially a police power. Sometimes it was also a directing power. Again, as the authority of the Church could no longer control the social activities in detail, neither could it hold together the larger groups into which society was divided. But these groups were parts of one whole, and had to be held together in some fashion by other bonds. These were found in International Law. The explanation of these two phenomena, the State and International Law, was the problem of philosophy throughout the seventeenth and earlier eighteenth centuries.

The conception of the State.-The general position of Hobbes was practically that of his successors, and in a measure of the spokesman for the more precocious Italian political consciousness, Macchiavelli. "The State was conceived, not teleologically, but in a purely naturalistic fashion as a product of needs and interests." I

Egoism became the principle of all practical philosophy; for if the individual's instinct toward self-preservation was to be restricted and corrected by the command of the State, yet this State itself was regarded as the most ingenious and perfect of all contrivances which egoism had hit upon to attain and secure its satisfaction. The state of nature, in which the egoism of each stands originally opposed to the egoism of every other, is a war of all against all: to escape this the State was founded as a contract for the mutual warrant of self-preservation. The social need is not original; it only results necessarily as the most efficient and certain means for the satisfaction of egoism. ${ }^{2}$

The desired results might be best secured by the absolute monarchy, according to the Englishman Hobbes and the Frenchman Bodin, or by an aristocratic republic, according to the Dutchmen Spinoza and Grotius. A democracy was not yet considered practicable or desirable; for the democratic tendency inherent

I Windelband, op. cit., 426.

2 Ibid., 434 . 
in the commercial development had to be subordinate to political ends. The government that could carry forward the interests for which it was conceived to exist had to be strong. Only after relative stability was secured through the establishment of such governments could men go to the full length of the implications of the contract theory and advocate democracy, or the carryingforward of the interests of the individual regardless of government. The theory of the Revolution, though implied in the fundamental conceptions of all the social philosophy of the time, was given definite expression only under special conditions, as by Milton $(165 \mathrm{I})^{\mathrm{x}}$ and Algernon Sidney $\left(\mathrm{I} 68_{3}\right),{ }^{2}$ when the misrule of the sovereign made men believe that the governmental contract should be liable to dissolution.

The contractual theory of government was not original with Hobbes. As already stated, Occam and Marsilius and other thinkers of the early Renaissance had put forward the same view. The experience of corporations, urban, ecclesiastical, and economic had given a suggestion of the method by which the larger political organization had come into being. Indeed, before the National State came to play so important a part, the doctrine of popular sovereignty received an emphasis which was lacking in the time of Hobbes. ${ }^{3}$ These theories could not have been unknown to the later writers; but these had a phenomenon to explain and an institution to justify with which their predecessors were familiar, namely, the National State. Their individualistic view made it necessary to assume an original voluntary agreement and the revolutions in England and frequent acts of agreement between rulers and subjects gave them added proofs of the contractual nature of the political bond. Their special point was the indissoluble character of the contract when once made; and this assumption seemed necessary to justify a government that could be sufficiently strong and stable to meet the needs of their time. After the nationalistic movement had settled the ques-

I Defensio pro populo Anglicano.

2 Discourses of Government.

3 Cf. Gierke, op. cit., 37-6r. 
tions then prominent, men could go back to the earlier, nominalistic conceptions of popular sovereignty, and, re-enforcing these with the individualistic psychology of Hobbes, could begin a struggle for the rights of the individual.

The Law of Nations.-Proceeding from the same assumptions from which the doctrine of sovereignty had been developed, a philosophy of law also was worked out. The practical application of this was found chiefly in the international sphere. As the social conditions had led to the development of the National State, so they made necessary some kind of an understanding that would prevent constant warfare between states. The beginnings of the important substitute for the old feeling of community which had been sustained by the Church and the Empire were found in the blending of the pacificatory measures of the Church, the maritime practices of the Mediterranean cities, and the Roman Law.

From the middle of the eleventh century, the "Truce of God" was more or less well observed; notably so in Aquitaine and Languedoc. This peace was not the peace of the towns, though the burghers were especially favorable to it because of their interests in the open country where the town peace did not hold. ${ }^{x}$ From the prohibition of private war, it was a short step to the prohibition of other violent customs, such as the rights of wreckage, the pillaging of merchants and sailors, etc. The councils of Clermont (II 30 ) and Rheims (II 1 I) anathematized those who should commit such offenses. ${ }^{2}$ In I 68 Alexander II reproached the Genoese for acts of piracy on the commerce of Montpellier. ${ }^{3}$ The fact that these steps were taken is an indication that commerce was reviving. As soon as this revival had gained headway, there grew up a body of customs and common traditions which finally became an international code of navigation. Undoubtedly the tradition of the ancient maritime code, the Law of the Rhodians, which had been accepted by the Roman Empire, served

× Pirenne, Revue historique, LVII, 294.

2 Pigeonneau, op. cit., I, I20, I 2 I.

3 Ibid., 163. 
as the model for the codes of the principal ports of the Mediterranean, especially of Amalfi, whose code served as the basis of later maritime jurisprudence; ${ }^{\mathbf{x}}$ yet the influence of the Christian spirit and of the efforts of the Church to modify warfare and violence is seen in all of these laws. The completion of the Rôles d'Oléron took place in the twelfth century, when the interest in Roman Law likewise inspired the Canon Law and the beginnings of the municipal codes. This code was given its final form in Aquitaine, whence it passed into Bretagne, Normandy, and later into England, the Netherlands, and the Baltic countries. The other important maritime code, the Consolato del Mare, was compiled at Barcelona a century or more later from the statutes of the maritime cities of Italy, Spain, and southern France, and became current in the Mediterranean ports. The essential characteristics of these two codes were identical. They regulated the relations of shipowners, undertakers, pilots, and sailors, rights of marque and reprisal, practices in case of accidents or pressing danger, and practically suppressed rights of wreckage and other barbarous customs. ${ }^{2}$

These practical regulations, strengthened by religious sanctions and supported by Roman precedents, were fairly adequate so long as mediæval institutions survived and commerce was carried on by the smaller commercial communities; but when the new world was opened up and the great nations began to struggle for supremacy, piracy and war needed new definitions, and new sanctions had to be found for a modus vivendi among civilized nations. The foundations of modern International Law were laid by Hugo Grotius in I609. The practical stimulus for his work was the fact that the first great colonial powers, Spain and Portugal, had secured the papal sanction for a partition of the whole oceanic world between them as their exclusive property. Against this ecclesiastical limitation, the doctrine of Mare Liberum, based upon the supposed law of nature, was put forward as a justification for the appropriation by the Dutch of

I Op. cit., r6r, r62.

2 Ibid., 162-64; Walker, Science of International Law, 395. 
these colonial possessions of Spain and Portugal. The doctrine had to be modified to meet the requirements of England and Denmark, which could not be expected to relinquish the exclusive control of their contiguous waters; but the general principle of a free open sea soon gained general currency. Another stimulus to Grotius was the barbarism of the Thirty Years' War, which witnessed a degeneration from the standards of an earlier age. It is true that the worst horrors of that war had not taken place when his great work, De Jure Belli ac Pacis, was given to the world (1625); but the practices of the times had become sufficiently revolting to lead him to write:

I saw prevailing throughout the Christian world a license in making war of which even barbarous nations would have been ashamed; recourse being had to arms for slight reasons or no reason; and when arms were once taken up, all reverence for divine and human law was thrown away, just as if men were henceforth authorized to commit all crimes without restraint. ${ }^{\text {I }}$

This degeneration, caused by the dissolution of the old ecclesiastical bonds, made all thoughtful men anxious to find a better way; and it was not surprising that a Dutchman should be foremost in seeking it.

The real sanction of a Law of Nations was the fact that the various nations formed a single moral community. The consciousness of this had been developed during the Middle Ages. Now, however, when the ecclesiastical sanction could no longer be acknowledged and an organic conception could not yet be attained, it seemed that the community was justified only because of the immediate advantages derived from it; just as the political State was justified by the selfish advantages secured by it to individuals. The Law of Nations, like the doctrine of the State, was based upon the lex naturalis, that is, the law of human nature. It was upon the interests of individuals co-ordinated by agreement that the State was based; so it was upon the interests of individuals and of individual nations harmonized by definitive treaty, or the commonly accepted maxims supposed to be derived from

I Prolegomena, $\$ 28$, quoted by Lawrence, The Principles of International Law, 42. 
nature, that a community of nations was to be established. The social structure must be based upon social needs; but society itself had no life of its own. The old universals having been exhausted, the stimulus to social activity was naturally found wholly in the particulars; but there were no longer any great unifying ideals which could control the particulars. The more immediate political and economic ends took the place of these in part, and established conceptions set limits beyond which mutual aggressions should not go; but the friction was necessarily great during the time when there were neither old habits to guide nor ruling ideals to control. This lack of system and harmony in the new conceptions and in the new social order could not occasion the resuscitation of the Church. That institution had forever lost its authoritative position in society. So it was upon contract and the self-evident maxims of Natural Law that Grotius and his followers had to depend for a bond of union among the nations of Christendom. "The principles of Natural Law," wrote the great jurist, "if you attend to them rightly, are of themselves patent and evident, almost in the same way as things which are perceived by the external senses."I It was because of the wide acceptance of this view that the rules proposed by Grotius were at once adopted by the civilized world. In the Peace of Westphalia its leading principles were recognized and applied, and it soon found its way into the universities. To deny its sanctions was to do that which was unnatural. Of course, the force of the proposed code was due to the fact that it was based on principles which the Christian consciousness had absorbed. To this common consciousness Grotius could appeal, and when he brought together precedent after precedent drawn from sacred and profane history, and with the aid of his legal knowledege worked these out in an intelligible system, the argument was irresistible. But the wide prevalence of the foolish theories about the law of nature enabled him to clothe his new system with all the authority of admitted theory. ${ }^{2}$

I Prolegomena, $\$ 39$, quoted by Lawrence, op. cit., 40.

2 Lawrence, op. cit., 4.3-47. 


\section{THE DEMOCRATIC MOVEMENT}

The thought-movement which we have just traced was the result of an effort to understand and justify the political development that was going on. Basing everything upon an individualistic conception, it was nevertheless not democratic. Under the influence of the stirring political events of the times, men's minds were directed to the explanation of the larger movements which nècessarily included all individual interests; and yet the change of the stimulus to social activity from the whole to the particular made it necessary that all explanations should be based upon an implied individualism. This having been taken as the key to the new systems, it would inevitably follow that attention should be directed, sooner or later, to the individualistic presuppositions themselves. This was what happened in the philosophy of the Enlightenment.

There were several reasons for this transition from political to what may be called social philosophy. The consolidation of the nations under relatively stable governments, the establishment of a "balance of power" that could not be easily disturbed, and the recognition of certain limitations to international rivalries both in war and in peace, withdrew political problems from the active interest of the world. The stability of the State made it possible for men to think of the reform of the State in such a way as to give the individual greater freedom. The intermediate groups between the State and the individual had been obliterated by the development of the former and by the economic changes following the fall of the cities. The State had been obliged to suppress the gilds and corporations which had once controlled the activities of the individual, and the development of the national economy prevented the rise of new groups. The use of the forms of the old organizations for the political control of industry, as under Elizabeth in England and Louis XIV in France, was in no sense a revival of the gilds. The latter had always been socialeconomic institutions having economic ends, to attain which they might sometimes employ political means. The later, galvanized gilds were maintained for political ends to which the 
industrial activity was frequently necessary. Nor was a state church to be considered as serving the same purpose as had previously been served by the Church. These later institutions were designed to control the religious life of the nation in the interest of national policy. The manor had long since passed away, except in remote agricultural regions; and both village and family had ceased to hold the individual. Some measure of self-government was left to some of the towns; but it was strictly regulated by the central power, and was limited to minor local affairs. The orders of nobility had been displaced by courtiers who were creatures of the ruler. Thus the very success of the State had swept away all that bound the individual save the State itself. However supreme the State might thus make itself, it was preparing the way for a struggle in which the individual would contend for the delimitation of the province which the State should occupy. ${ }^{\mathbf{I}}$

The breakdown of intermediate groups brought to greater prominence ihe individuality which had been developing for centuries and which had become the really important fact of social life since the rebirth of commerce. Serfdom had disappeared except in a few backward districts, and the necessities of private initiative had resulted in the development of a great body of self-reliant individuals engaged in the essential activities of social life. The gilds had taken the place of the manors in mediating between these individuals and society; consequently the consciousness of the social values of the actions of the individual was not present with the masses of the producers. But such a consciousness became highly developed in the men whose duties gave them positions of leadership or cut them loose from established conditions. This sense of individuality was greatly extended by the rapid changes in industry and the opportunities for adventure opened up by the geographical discoveries. The enlargement of industries created a class of workmen-not yet numerous, but destined to increase-who could never become masters nor have a voice in the determination of craft policies, but who could

I Cf. Gierke, op. cit., 87, 88, 99, 100 . 
no longer be treated as the serfs or servants of masters and rulers. During the period of the disintegration of the gilds, many workmen were detached from their communities and liberated from the last vestiges of personal control by industrial institutions. As the agricultural serfs had become gild-brethren, so now the artisans became free individuals when the changes in industry made it impossible for mediæval institutions longer to hold them. This class became more and more numerous until, finally, the Industrial Revolution completely shattered the remnants of the old system.

This separation of the individual from the institution and the development of conscious individuality was furthered by the voyages of discovery and adventure, and the settlement of new countries. The men who engaged in these enterprises, even when they went to the colonies as indentured servants, were necessarily thrown on their own resources to such an extent that their self-reliance and individuality were heightened. An incidental, but important, result of the discoveries was the enormous inflation of the currency of all Europe by the importation of the precious metals. This inflation bore upon the development of conscious individuality by breaking down many of the social ranks and by scattering men as wage-earners. Prices were raised to the advantage of the agricultural laborer and ultimately to that of the artisan, but to the ruin of many of those who depended upon fixed money revenues. - In short, the whole tendency of the times was toward the destruction of status, although that consummation was not reached until the end of the eighteenth century.

The Reformation, caused by the growing individuality, likewise led to an increased emphasis of the individual. When the reformers reacted against the Church, they naturally tended' to place the individual over against the institution. Before the reformed churches became state institutions, the only hope of their leaders lay in their appeal to the individual. The value of the individual had been one of the most important truths proclaimed by the Church; but this appreciation of the individual having been possible only in emotional terms, and the practical 
importance of the work of absorbing the ideals of Christendom having been so great, the authority of the institution and the sacredness of the social order for which it stood had come to occupy the whole attention of the ecclesiastical leaders. After slavery had disappeared and serfdom had been ameliorated, the Church had ceased to pay much attention to the earthly condition of the common man; or, indeed, regarded the betterment of that condition with alarm. When the emotional individuality was becoming one of activity, the tendency to look back to the more ancient traditions for guidance was strengthened by the discovery of Augustin's position regarding the importance of the individual. This new preaching of the doctrines of Jesus and Paul and Augustin, the appeal to the individual to search the Scriptures for himself, to come into immediate relations with God, discarding the intervention of the priest, gave an impulse to the development of a consciousness of individuality which the deadening influence of the state churches and later of the bigoted denominations could not counteract. The earlier reformers laid special emphasis on the relation of the individual to God. Luther's earlier writings abound in his expressions of belief in the freedom of the individual Christian and the spiritual equality of all men. When he beheld the turmoil into which the Reformation was throwing Germany, he returned to the principle of authority and laid the foundation for the doctrine of cuius regio, eius religio. But even after the state churches were established, the leaven continued to work; and the persecution of non-conformists even tended to throw them back on a more intense individualism-an individualism strong in the consciousness that God was backing, though all the public powers were attempting to suppress it. In England nonconformity succeeded in bringing about the moderate political improvements which began with 1688. In France the individualistic tendencies were held in check until the Revolution. The petty absolutism of Germany, after the religious wars, and the selfish dynastic policies of all the princely rulers, caused men to despair of public morality and to find freedom and humanity 
within the individual breast; ${ }^{\mathrm{x}}$ and this individualism, appearing in both the pietism of Spener and the rationalism of Leibniz, had an influence in religion and philosophy which reached far beyond Germany.

These influences were important as bringing to self-consciousness the individuality which had been developing ever since the rise of the new commerce. The individual had become an individual by virtue of his absorption of the inherited wealth of the past. Having absorbed the culture of the past, the individual became an epitome of society as it then existed. There was no longer place for an authority which, ranging itself on the side of the past, should enforce conformity to its standards. The ancient ideals had been realized in essential particulars. When he became functionally related to society, the individual became an individual. But for reasons already stated, the full consciousness of this individuality did not immediately arise. From the Renaissance to the Revolution it was growing; and the reality of individualism likewise grew as the masses were brought more directly into contact with the industrial movement.

The self-consciousness of individuality received its statement in the philosophy of the Enlightenment. In this the individualism that had been implied in the earlier thought and had been used as a sort of metaphysical basis for the explanation of social phenomena now became an active principle. The individual was seen to be important to himself; no longer as mere material for political organization. Therefore, problems of political and ethical authority were no longer to be settled from the standpoint of political ends. All institutions came to be regarded as the products of the activities of individuals, having no value save as they served individual ends, that is, contributed to individual happiness. As the ecclesiastical authority had been overthrown by the men of the Renaissance, so the political authority which had received such high development during the period of state formation was now called in question by the men of the Enlight-

ICf. the admirable statement of the condition of German thought after the Thirty Years' War, by Francke, Social Forces in German Literature, chap. vi. 
enment. The latter did not see that the growing democracy to which they were giving a powerful impetus would involve a political sovereignty as absolute as Hobbes or the Stuarts had ever claimed for monarchy. ${ }^{x}$

The new expression of individuality found its first clear statement in England, both because, since the transition from agriculture to manufactures, England had become the most advanced of the industrial nations, and had made the advance so rapidly that an extraordinary premium was bound to be put on individual initiative; and because England, more than any other country, felt the reflex influence from colonies where every man counted as an individual. Locke and Shaftesbury may be regarded as the initiators of this movement of thought, but it did not become powerful for social development until it passed into the hands of the French philosophers and was transformed into an instrument for revolution under the influence of a reaction against the extreme exercise of authority in economic and political affairs. Leaving out of consideration the influence of such men as Voltaire and Diderot, we notice the specific reaction against the French maladministration of justice in Montesquieu's demand ${ }^{2}$ for the application of some of Locke's constitutional checks, though the demand is not yet made for the substitution of popular sovereignty for absolutism; and against the extreme French mercantilism in the pleas of Quesnay ${ }^{3}$ and Turgot ${ }^{4}$ for economic freedom, which Adam Smith was soon to state in such impressive form as to make them the foundation of economic science.

In all of these discussions the standard of value for ethical functions was more clearly held to be the satisfaction of the impulses of the individual. 5 At the same time, judgment was being passed on the social institutions according to their ability to contribute to the happiness of the individual. It was not a

I Cf. Willoughby, The Nature of the State, 181-23I; Burgess, op. cit., I, 51-57.

2 De l'esprit des lois (1748).

3 Tableaux économiques ( $\left.175^{8}\right)$.

4 Reflexions sur la formation et la distribution des richesses (I774).

5 Cf. Windelband, op. cit., 5 or. 
long step from this position to the theory of revolution as developed by St. Lambert, Condorçet, and Rousseau. Man was still regarded as by nature essentially egoistic, as Hobbes had held, but he was also regarded as having feelings that were naturally good and social, so that there was no need of a strong government to force him to keep the social compact. The effect of the historical development, of so-called knowledge and refinement, of the artificial social structure, had been but to make man untrue to his real nature. Therefore, history should be begun anew, in order that man might develop from his simple natural condition to that perfectibilité which his nature indicated to be his true end. Here we find a clear statement of the individualism which had been implicit from the beginning of the Renaissance. The whole social value was in the individual. Now this individualism could not have been given the statement it received by Rousseau, had not the individual come into such organic relations with society through the previous development. Rousseau's individual was a social individual. He was capable of being used as a tremendous social force simply because he was not in a state of nature, but had absorbed all the values of society. Rousseau, however, did not realize this, nor did the men who made use of his doctrine. The important thing at that time seemed to be to sweep away the institutions of authority which seemed to be merely obstructions to the free working of the individual. The regulation of free individuals did not seem to the men of the eighteenth century to be the problem which the nineteenth century has found it to be. They were probably right in ignoring it, for their own problem was the freeing of individuals from artificial restraints. Therefore, neither the absolute monarchy of Hobbes nor the constitutional monarchy of Locke could be tolerated. "The individual had never agreed to surrender his natural rights. He never would do so. The government was but a servant. If it proved unfaithful, it should be dismissed and replaced by another. The sovereignty should be vested in the people: there was to be a fraternity of equal individuals, and in political action the general will was to prevail. Here was a virtual contradiction of the theory 
of self-sufficient individualism; but until it had to be applied, after the triumph of democracy, the contradiction did not appear. So the doctrine as stated by Rousseau was simply a tremendous intellectual weapon in the hands of the radical party.

This thought-movement culminating in the French Revolution was important for social development, not merely as symptomatic of the coming to consciousness of the individual, but because the theory was immediately applied with such momentous results, and continued to be the ruling ideal of Christendom for a long time, indeed, to the present day among the masses. When individualism was once cliarly stated, the democracy at once recognized it as that for which it had been feeling, and immediately asserted itself. The immediate application of the doctrine indicates the force of the individualism already in existence. The democratic triumph marked the close of the transition period following the Middle Ages.

The counter-revolutions which followed the French Revolution did not materially interfere with the steady advance of democracy. Their only significance arose from the fact that the Revolution did not provide for the co-ordination of the activities of the individuals whom it had freed from the last vestiges of authority. Under these circumstances, it was but natural that men should turn from the new system that did not work to an old one which had once been efficient; and only later discovered that the old system would no longer work, but that a new social order must be developed on the basis of democracy. Whether the Revolution helped or hindered the democratic movement, we may be unable definitely to determine; but that the movement itself was furthered by the philosophy which was at the same time a reflection of it, can scarcely be questioned. The individual was not only freed, but was made conscious of his freedom. The eighteenth century, as Mazzini said, made good the right of the individual to be an end in himself. The collectivistic movement of the nineteenth century, the seeds of which we have found in Rousseau's individualism, has been based entirely upon this outcome of the previous development. 


\section{CHAPTER VI}

\section{SOCIAL MOVEMENTS OF TODAY}

It would be impossible within the limits of a work like this to give anything like a detailed account of the complex developments of the nineteenth century; and, indeed, in the presence of numerous valuable treatises on various social movements, such a work would be unnecessary, save as it should attempt to fill in some of the gaps which still remain. It will be the object of this chapter to present no more than a general view of these most complex movements in their econonic, ethical, and political aspects, at the same time considering the peculiar problem with which we have dealt throughout, namely, the relation of the particular to the universal, of the organ to the organism, of the individual to society; and endeavoring to discover whether the social integration which we have traced still proceeds, or whether elements of disruption and decay are gaining the supremacy.

Two important phenomena are typical of this period, namely, the establishment of democracy and the rise of modern industry. Nearly all, perhaps all, other social problems arise out of these; and these are so intimately related to each other that they may be regarded as virtually one. At the close of the last chapter we considered the development of the consciousness of the value of the individual, culminating in the theory of the Revolution. This meant ultimately political self-consciousness. Having at last come to function with comparative freedom and immediacy for society, the masses, now that they had become conscious of this relation, could not be prevented from asserting their right to take a hand in the management of political affairs. Where certain classes were enjoying privileges without performing any social service, as notably in France, the uprising was naturally more violent than elsewhere; but everywhere, as the masses came to realize their power, their encroachment upon the political rights of the governing classes went steadily on. Even in America 
the democratic movement broadened after independence was assured and the earlier constitutional problems had been settled for the time. ${ }^{x}$ The French Revolution was but an incident; and the reactionary movements likewise could be of but momentary importance. The French theorists, some of them even belonging to the nobility, precipitated the Revolution; and the American Revolution had been inspired and pushed to a successful consummation by a comparatively small intellectual aristocracy which proclaimed under favorable conditions the same theories regarding the rights of man that were soon to cause the upheavals in the land of their origin. Nevertheless, the democratic movement was a reality which might be hastened by these special stimuli, but could be made neither more nor less inevitable and powerful by them. It was the culmination of that emotional individualism, of that realization of the value of the individual because the Absolute was back of him, which had been influencing all social movements since the time of Jesus. Now the individual had come to realize that all the values of society were focused in him, as he had formerly believed the spiritual forces of the world were working for him; and accordingly he set about appropriating the world about him as he had formerly appropriated the heaven above him. As the latter had been secured through ecclesiastical mediation until the transformation above described rendered that no longer necessary; so, during the period of political reconstruction, control of the social order was secured

I In England the middle classes had forced their way into political power through the Puritan revolutions, but these became assimilated with the aristocracy before the middle of the eighteenth century. A new middle class did not secure similar recognition until $183_{2}$, and democracy was not fully established until 1867 . In Germany the masses did not obtain the right to participate in government until about the time of the unification of the empire, and the aristocratic element is still strong in that country. In France the revolutionary establishment of democracy meant that the masses had come to understand their power; but even to the present time, French democracy is scarcely able to apply itself to the steadfast pursuit of intelligently formed purposes. In America the Declaration of Independence did not mean the establishment of democracy; for until the close of the war all of the commonwealths retained property qualifications for the exercise of the suffrage, and not until 1828 did the masses throw off both legal and moral limitations on their power. 
through the monarch who ever appealed from the aristocracy to the masses; but after the formation of the national states and the establishment of law and order the individual sought to secure that control without mediation.

We have seen that this individualism grew out of the fact that the individual was socialized. Not only had he so absorbed the values of past civilization that he no longer needed to have these handed over to him by authority, but through the commercial development he had come to function with comparative directness for the whole society of the civilized world. Thus the individual became conscious of himself at the same time that he found his own interests identified with those of society. The individual and the kingdom were reciprocally related in the formal statement of Jesus; the emotional individual could realize an emotional brotherhood during the earlier transition period; the individual received something of an intellectual definition during the reconstruction of agriculture and commerce, but was then directly related to the institution, manor, or gild, and was not conscious of himself as an organ of society; finally, the individual has come to receive a definition in terms of the society of which he is an organic part. It is now possible to tell what an individual is in terms of his social relations, that is, by describing his daily duties toward his fellow-men and their obligations to him. The interests of the individual and of the whole are at least roughly identified. In pursuing his own ends, the individual furthers the ends of society.

It was therefore possible for the political philosophers of the eighteenth century to regard the individual as the social unit and to claim for him complete self-governing powers; and for the economists of the latter eighteenth and earlier nineteenth centuries to adopt the laissez-faire theory, contending that when all individuals follow their egoistic tendencies the ends of society are best attained, since the individuals had become socialized, had become social organs. Conversely, the collectivistic theories of the present century are possible only because the value of the individual has become recognized. That complete individualism 
or complete collectivism can not be realized in actual practice does not controvert the truth involved in both of these positions. The general nature of society and of the individual may be such as to render either or both of these normal; and yet existing social structure may for a long time resist change, or abnormally egoistic or abnormally indolent individuals may forever be found in such numbers as to prevent the realization of complete individualism or complete collectivism.

In this connection it is worth while to note that the most ardent socialists of continental Europe are likewise anarchists. State socialism, the socialism of Rodbertus and Bismarck, is regarded by the more thoroughgoing socialists as an antidote for their movement. And if the socialists of America and Great Britain are willing to attain their ends through the activity of the present political organization, it is only because the individual feels that he has greater freedom in those countries and believes that he can control the government wholly in the interest of the masses. Practical socialism is not far removed from anarchism; collectivism always implies individualism; Marx builds his theories on the foundations laid by Ricardo.

We are not here concerned with the goodness or workableness of any of these programs: it is sufficient to observe that they are illustrative of the fact stated above, namely, that the individual is defined and recognized as having actual value only as his daily activities come to serve social ends, and that the definite statement of society can be made only on the basis of the active individual. The more positively the freedom of the individual is asserted, the more necessary it becomes to find the law of his free activity. The collectivistic tendency of the present century is not a reaction from the individualism of the last: it is the continued evolution of the latter tendency. After Rousseau had stated the freedom of the individual, he found it necessary to reduce that freedom to order through the compact and the recognition of the general will. His "liberty" was balanced by "fraternity."

I "Trouver une forme d'association qui défende et protège de toute la force 
Even at the end of the eighteenth century it was impossible to find adequate terms for the expression of the new individual. In so far as Rousseau could not tell on what the rights he claimed for the individual rested, he had to fall back on feeling. In so far as a positive statement could be given, it was because the social activities, chiefly economic, had been so highly developed. Now the further positive definition of the individual and the more complete attainment of self-consciousness on the part of the masses, which had been so stimulated by the revolutionary philosophy, was to be secured through the further industrial development. And through the same influences the collectivistic tendencies were likewise advanced as never before. The organic solidarity of society begun by "commercialism" is furthered by "industrialism."”

\section{THE EXTENSION OF DEMOCRACY}

The capital facts of the movement we are now tracing are the Industrial Revolution and the settlement of new lands-both made possible by the improvement of means of transportation. Taking the second first, because it both influenced the former in the older sections and was the forerunner of industrialism in the newer ones, it will be sufficient to consider briefly the effects of the settle. ment of the territory of the United States west of the Alleghenies. The influences noticed here are practically the same in kind as those produced by similar movements in Canada, Australasia, and even to some extent in Spanish America.

Attention has already been called to the fact that, from the beginning of the transoceanic discoveries, the self-reliance and independence of the explorers and colonists had much to do with the development of individualism, even to the extent of reacting on the mother country. Europe has not ceased to feel the influence of the democracy of the newer countries, though that influence commune la personne et les biens de chaque associé, et par laquelle chacun s'unissant à tous, n'obéisse pourtant qu'à lui-même et reste aussi libre qu'auparavant. Tel est le problème fondamental dont le contrat social donne la solution. . . . . Chacun de nous met en commun sa personne et toute sa puissance sous la suprême direction de la volonté générale; et nous recevons en corps chaque membre comme partie indivisible du tout." $-D u$ contrat social, Book I, chap. vi. 
has not been so strong in recent years as it formerly was. The more recent democratic developments in Europe have been the product of industrialism.

After the American Revolution the emigrants to the western country were bound to become more democratic than the earlier colonists had been, both because they were completely cut off from all contact with the aristocracy of England, and because they carried with them the theories concerning the rights of man which had been vigorously proclaimed in the original states. Contact with civilization was sufficiently close to prevent degeneration, for commercial and political interests alike stimulated the people and the government of the seaboard states to open the routes to the new settlements. The Erie Canal, the Cumberland Road, the Baltimore and Ohio Railway, and the Louisiana Purchase assured constant intercourse and interchange between the frontiersmen and the more thickly settled portions of their own country and the rest of the world. It was but natural that a remarkably strong democratic sentiment should grow up west of the mountains, and that it should react upon the rest of the country.

It is well known that the earlier political organization was far less democratic than the present. In the beginning a property qualification was very generally required for the suffrage, and property and religious qualifications were required for nearly all offices. Until 1829 the presidents belonged to an aristocracy of culture and statesmanship. Public officials were chosen by the people from among their recognized leaders, and they were chosen as leaders of public opinion. Although advocates of the rights of man, these leaders often "conceived of popular opinion as aggressive, unreasoning, passionate, futile, and a breeder of mob violence." After the Revolution was accomplished, the most ardent of the opponents of a strong central government feared encroachments on state rights rather than on individual liberty, and were willing to trust the protection of the rights of the people to strong state governments controlled by the "best" people of the smaller areas. 
Beginning, however, with the presidential election of 1828 , there has been a marked change to a more radical form of democracy. An appeal was then made to the masses against the aristocracy of the East; and from that time to the present, with now and then an exception, public opinion has led, rather than followed, the public servants of the nation. The jealous demand on the part of the people for a more direct control of government has gone on increasing in urgency until the state constitutions have become masses of directly enacted statutes-the difficult process of amendment of the national constitution having prevented a like change in that instrument-legislators have become little more than delegates, and successful politicians have found it necessary to spend most of their time observing and following the currents of a fitful public opinion. ${ }^{x}$ The talented commentator on American institutions contrasts this condition unfavorably with the leadership of the statesmen in the House of Commons. That this change has been detrimental to the development of great statesmanship and has put a premium on the arts of the demagogue, there can be no doubt; but there is reason to believe that the evils of extreme democracy will work themselves out, and that the final results will be wholly in the interests of social and individual welfare. English statesmanship seems to be losing its leadership, and the encroachments of the masses upon their self-constituted leaders in Germany is becoming constantly more significant. The cure is to be found in the further development of democracy, rather than in the return of the people to tractable acceptance of leadership. "Public opinion grows more temperate, more mellow, and assuredly more tolerant. Its very strength disposes it to bear with opposition or remonstrance. It respects itself too much to wish to silence any voice." Certainly, other things being equal, it is desirable to have the largest possible number of individuals realize their importance in the social system.

More important, perhaps, than this democratic tendency in politics was the growth of the democratic spirit of which the politi-

I Cf. the admirable discussion of public opinion in America by Bryce, American Commonwealth, II, 247-374. 
cal aggressiveness was but one of the expressions. In the earlier days the frontiersmen were never backward about making demands for public lands and better means of communication; ${ }^{\mathbf{I}}$ and this tendency, sometimes almost socialistic, to use the government for the promotion of economic ends, even of an extremely local sort, has been one of the fruits of the independent and democratic spirit ever since. Naturally, this democratic spirit would infect the older sections; and, after having been intensified by the industrial development, it has come to influence every phase of American life, from the control of the highest functions of government to the employment of domestic servants. This influence of newer settlements has done much to extend the democratic spirit in those countries which have come in closest contact with them. But this spirit is softened with the lapse of time, and the descendants of the pioneers may become almost aristocrats. It is the industrial development which causes the permanent expansion of democracy; for the industrial army can not be wholly elevated above the plane of struggle. The influences of industrialism are deeper than those of pioneer life, as well as more permanent. It is these which are back of the most profound social changes that are now occurring. They are intensifying the democracy of America and are responsible for a more profound democratic spirit in Europe than the earlier movements ever aroused. The European democrats of 1848 were inspired by eighteenth-century political philosophy and by American experience. The democracy led by Herr Bebel has felt these influences only indirectly: it is a more direct product of the Industrial Revolution.

\section{INDUSTRIALISM}

Turning now to the more important movement of this period, we find our natural starting-point in a consideration of the indus-

I An examination of the records of Congress reveals the fact that the nearest approach to a "labor problem" in the thought of public men, from the Revolution to the close of the war between the states, was in the attempt to meet the demands of these independent farmers for free lands or for the extension of time for the payment of government charges. And the construction of roads, railways, and canals by the national government and by the state governments aided by the national government was an absorbing issue until the crisis of 1848 . 
trial development of England. The situation in England was such that the great industries sprang up there earlier than elsewhere and became more nearly the whole interest of the people. But wherever else the industrial movement has gained headway, the results have been practically the same; and we may say that all of the more important nations have passed through at least the earlier stages of this important economic transformation.

The Industrial Revolution.-The Industrial Revolution was not the result of the great mechanical inventions: rather, the inventions were the result of the Revolution, though, of course, the former in turn greatly accelerated the latter. The essential feature of this social change was the minute division of labor, making possible the profitable enlargement of manufacturing establishments, which in turn stimulated the invention of laborsaving devices. This division of labor depended upon the extent of the market. ${ }^{x}$ Even after the extensive development of commerce already described, the market was very limited in extent as compared with that of the present day. The division of labor between the important geographical areas was quite complete. No communities were longer self-sufficing, even the poorest agriculturists and domestic weavers always exchanging some surplus for commodities produced elsewhere; but the means of communication, up to the middle of the eighteenth century, were so poor that few of the commodities now so important to commerce could have borne the costs of transportation, and the demand for the more staple commodities was limited for the same cause. According to contemporary accounts, such as Young's and Defoe's, the roads of England were almost impassable; and those of the Continent were probably no better. Commerce depended chiefly

I "As it is the power of exchanging that gives occasion to the division of labor, so the extent of this division must always be limited by the extent of that power, or, in other words, by the extent of the market. When the market is very small, no person can have any encouragement to dedicate himself entirely to one employment, for want of the power to exchange all that surplus part of the produce of his own labor, which is over and above his own consumption, for such part of the produce of other men's labor as he has occasion for."-Adam Smith, Wealth of Nations, Bk. I, chap. iii. 
on water. transportation. Here England had the advantage over all other large nations, for both her coast-lines and her internal waterways were of such a character that communication could be kept up by water between the various important sections; and when, beginning about $\mathrm{r} 755$, numerous canal systems were constructed, ${ }^{\mathbf{I}}$ it became possible to carry on the exchange of commodities even more cheaply than would have been possible with good roads. ${ }^{2}$

There were, however, other reasons for the continued narrowness of the market and for the earlier improvement in England than on the Continent. The roads were probably not so bad as some writers would lead us to believe from accounts of their own experience. $^{3}$ They were certainly bad enough to check commerce; but the miseries which could cause the traveler for pleasure to give us a gloomy picture might be taken as a matter of course by the business man. The chief reason for the continued limitation of the market was the fact that the wants of the masses, rendered so simple by the long period of privation, could expand but slowly. With the improvements in agriculture and the beginning of a real division of labor, many of the greater comforts became necessaries; but the multiplication of the wants of the masses could be only by slow process, especially since the survival of the conception of an appropriate station in life for each individual yielded but slowly to the demands of the new situation. Here, as always, demand and supply were reciprocally related; only as new wants emerged was there a stimulus to the more complete division of labor; only as new products were made available could new wants arise. Under these circumstances, while the world had entered fully upon a new economic era, progress could be by slow stages only. Satisfaction with some-

x Toynbee, The Industrial Revolution (Humboldt ed.), 52; Gibbins, Industry in England, 355, 356.

2 Cf. Adam Smith's estimate of the comparative cost of transportation by road and by water from London to Edinburgh, op. cit., Bk. I, chap. iii.

3 Rogers, Econ. Int., 483; Gibbins, op. cit., 354. Contra, Toynbee, op. cit., 52; Macaulay, History of England, I, chap. iii. The last citation is largely responsible for many other exaggerated statements that have passed current. 
thing a very little better than the past generation had enjoyed rendered the demand progressive, but sluggish. The feeble demand meant a restricted market, and therefore but imperfect division of labor; the imperfect division of labor prevented the population from increasing rapidly, ${ }^{\mathrm{I}}$ thus, at the same time keeping down both the demand and the possibility of industrial expansion. As the profits of sheep-shearing had long kept England from embarking in manufacturing, so the long-continued devotion of the majority of the population to agriculture held them back from other industries, even after the latter had become more profitable; and after weaving had become the great industry of England, it was carried on extensively on the domestic plan, thus affording little stimulus to labor-saving inventions and rendering England more backward than any other nation. ${ }^{2}$

The expansion which led to the Industrial Revolution was due to colonial expansion and its results. In the first place, the colonies proved to be profitable markets. By natural inclination and because of restrictive legislation, the Americans purchased practically all of their manufactured goods from the mother country. English exports had increased from about $£ 7, \infty 00, \infty 00$ in 1700 to $£ \mathrm{r} 4,500,000$ in $\mathrm{I} 760$, and one-third of the exports went to America. Meanwhile, the Navigation Acts (165I and I660), narrow and short-sighted though they were in some respects, had resulted in the building-up of a large merchant marine and a powerful navy. The shipping business doubled in the first half of the eighteenth century; and the navy became strong enough to compete with all others combined when the struggle began for the possession of India and America.

In the next place, this struggle, which in 1763 ended in English supremacy in both India and America, resulted in an added stimulus to trade in the enlarged markets. There was greater

I Before I75 I the largest decennial increase had been about 5 per cent., while for each of the next three decades it became rapidly greater, reaching 14 per cent. for the decade ending $180 \mathrm{r}$ and over $2 \mathrm{I}$ per cent. in the next. The total population of England and Wales was 6,736,000 in 1760 , while that of England alone was $12,000,236$ in 1821 . - Gibbins, op. cit., 349.

2 Rogers, Econ. Int., chap. xiii. 
security in America; and England's greatest industry was developed through closer contact with India. This was the cotton industry, the first to develop the factory system and the one to set the pace for all others. This industry had been introduced into England by fugitives from Antwerp, when that city was taken by Alva in 1585 . They settled in Manchester and built up a small but flourishing industry. ${ }^{x}$ Only the weft of their cloth was cotton thread, the warp consisting of linen yarn from Germany and Ireland, since there was no machinery fine enough to weave cotton only, nor had the weavers the skill of the orientals. The entire value of all cotton manufactures in England in I760 was but $£ 200,000$ and but little over a million pounds of raw cotton was consumed. ${ }^{2}$ India had been the chief producer of cotton cloth; and after the establishment of closer commercial relations with that country-beginning even before the final expulsion of the French-the Indian product became a strong competitor with the English. But this competition, instead of destroying the home industry, stimulated it to improve its methods until the competition was driven out. The industry had already gained sufficient headway to make a struggle for existence worth while. The importations from India increased the demand for cotton goods, and the demand was made stronger by fashion set by the court. Thus a growing demand and the pressure of competition alike encouraged improvement. This was needed, for in 1760 the methods were as simple as those employed in India, while the quality of the product was not equal to that of India because the skill of the English weavers was inferior. Invention was encouraged by the free conditions under which the industry was carried on in England, and these were due to its comparative unimportance. On the Continent the methods were strictly regulated and the monopoly of the market was guaranteed to the dealers. Under these conditions there was little incentive to invention. In England the same policy was pursued with reference to the woolen industry; and the great

I Schulze-Gävernitz, Der Grossbetrieb, 26.

2 Gibbins, op. cit., 346, 347. 
importance which was attached to this industry by the nation accounts for the disfavor in which the feeble cotton industry was held and for the failure to support it by the laws. ${ }^{x}$ The cotton industry, then, by its unimportance secured that freedom which was essential to the stimulation of invention and at the same time was confronted by market conditions that made such improvements of method necessary and profitable.

The first factory of the modern sort was established by Arkwright in 1768 . The next year his water-frame was invented; and the next, Hargreaves' spinning-jenny. Crompton's "mule" was invented in I779; and by I8I I more than 4,500,000 spindles were worked by this device. Cartwright's power-loom, though invented in 1785 , was not brought into general use until 1813 ; and until then the domestic system of woolen weaving was not seriously injured. Indeed, the machines first introduced resulted simply in cheapening the cost and increasing the product of yarn, and therefore improved the business of the domestic weaver at the same time that a more extensive market was opened up for the cloth. The cotton business expanded rapidly, for all of these improvements led to increased consumption, which in turn led to further improvements, making still greater consumption possible. The quantity of raw cotton used rose from about $1,000,000$ pounds in 1760 to over $4,000,000$ in 1775 , to $11,000,000$ in 1784 , and to $56,000,000$ in $1800 .^{2}$ Here were all the conditions necessary for the most complete division of labor and for the continuous expansion of industry.

Meanwhile, inventions in another line were contributing two other important elements to the factory system-fuel and the steam engine. The problem of securing fuel for domestic purposes had become serious before the Industrial Revolution, and the trade in coal had been so important that the Stuarts granted monopolies in the supply of London. But since it was impossible to keep water out of the mines, the industry could have but little importance. This difficulty rendered the development of the

× Schulze-Gävernitz, op. cit., 34-36.

a Gibbins, op. cit., 347 . 
iron industry practically impossible. The use of iron was becoming more and more extensive, but most of the metal had to be imported. The presence of iron ore in England was known, and a little of it had been smelted with wood. After the revival of industry this smelting became more extensive, and by I7I9 iron ranked third in the list of manufactures. The trade then employed about 200,000 persons. However, the waste of wood became so great that the export or even the manufacture of iron was discouraged by legislation; and by $\mathrm{r} 740$ the annual output had been reduced to $17,35^{\circ}$ tons. A pressing demand therefore existed for the development of the coal mines, both for domestic fuel and for smelting. The Savery and Newcomen steam pumps were used with indifferent success to make the mines workable. It was when repairing one of the latter machines that Watt came upon the discoveries which he embodied in the steam engine in 1769. The new engine was soon brought into use to pump water from the mines, and later was used for hoisting purposes. In I785 the engine was introduced into the cotton mill. So this invention meant the immediate supply of all possible demands for domestic fuel, the immediate development of the iron industry, and the ultimate application of steam to all other important industries. The production of iron increased to 68,000 tons in 1788 , and the production has continued to increase until it is now about 9,000,$\infty$ tons annually, ${ }^{1}$ while that of the United States is about I8,000,000 tons. ${ }^{2}$

Without further description of the progress of invention and of factory development, we have in the account just given a statement of all the essential features of the factory system: increased demand, improved methods of transportation, increasing division of labor, growing populations, mechanical inventions, the application of steam-power, concentration of labor, employment of large capital, more strenuous competition for the control of the

×tatesman's Year-Book for 1905, 78. On the development of the mining industries, vide Gibbins, op. cit., 310-14, 352-54. On the early inventions, vide ibid., 343-47; Toynbee, op. cit., 90, and authorities cited by them.

2 Statesman's Year-Book for 1905, 1306, 1307. 
world-markets. The expansion was so rapid from the beginning of the reign of George III and its social effects were so portentous, that the change has not unnaturally been called the Industrial Revolution; but the more closely we examine the movement, the more we must be convinced that it was an evolution, rather than a revolution. It was simply the continuation with increasing momentum of the same movement which we have been tracing from the time when the independence of the manor gave way to a division of labor amongst the various parts of a unified world-society. The steady growth in the wants of the people, based upon their general prosperity and resulting in an increasing division of labor, was the essence of the Revolution. The position taken above-that the inventions were the result, not the cause of the Revolutionseems justified by the description we have given of the rise of those inventions. The movement had already begun, and was marked by the appearance of the capitalist, ${ }^{\mathbf{x}}$ the gathering of workmen into shops, ${ }^{2}$ and the division of labor, before these mechanical discoveries were made. Without the latter the tremendous results which have been achieved would have been impossible, but the change which they introduced was one of degree rather than of principle.

Capitalism.-The industrial movement has several phases which must be considered in their relation to the general social movement. These are usually considered under the aspects of the "growth of capitalism" and the "labor problem." To these the subject of modern consumption should be added.

Before the Revolution capital had little significance except in agriculture and commerce. Such simple tools and machines as

I Master manufacturers gave out work to be done in the homes of employees; e. g., in the Nottingham hosiery trade there were in $175^{\circ}$ fifty employers who "put out" work for I,200 frames; in Leicestershire I,800 frames were so employed; Manchester merchants gave out linen warp and raw cotton to weavers; nail merchants of Staffordshire and Worcestershire gave out nail-rod iron each week to workmen and their families.-Toynbee, op. cit., 53, 54 .

2 Arthur Young found at Sheffield a silk mill employing $\mathrm{I}_{52}$ hands; at Darlington a manufacturer employing over 50 looms; at Boynton a factory employing r5o hands. - Toynbee, ibid. 
were used in manufacturing were the property of the workmen themselves, and consequently had no such social importance as modern capital has. Agricultural improvements for the fertilizing of large farms and the carrying-on of the sheep-raising industry had made it necessary for large landowners to become capitalists. ${ }^{x}$ Commercial activity involved the use of a considerable amount of capital in the shape of vessels and stores of merchandise. The beginnings of the Revolution were marked by the employment of the capital of merchants in gathering the product of domestic manufacture into central warehouses, in supplying raw material to workmen who were paid a specific wage for their work upon it, and finally in supplying looms and other implements for the use of hired workmen either in their own homes or in a large building provided for the purpose. Here was the beginning of a tendency that would have resulted in the differentiation of the manufacturer from the merchant and of the artisan from the employer, even had machinery not come into such importance. Indeed, it is probable that the factory would have received a high development as far back as the Tudor period, had it not been for legislative interference with the ownership and hiring of looms. ${ }^{2}$ Nevertheless, except for the introduction of the great mechanical devices and the application of steam-power, capital could never have assumed the tremendous importance which it has attained. The function of capital, then, is the same in kind as it was before the beginning of machine industry, but the quantitative difference is so great as to constitute "capitalism" a virtually new phenomenon.

The immediate effect of the introduction of machinery was the increase of the size of the producing unit and the complete dependence of the workman upon an establishment which only large capital could make possible. No competitor could enter a field occupied by machine industry unless he could procure machinery, and this involved the investment of capital. And since the advantages of minute division of labor which character-

ICf. Gibbins, $o p$. cit., 212, 216, 27 .

Ashley, op. cit., II, 236, 237. 
ized the beginning of the Revolution were promoted by the use of machiney, a large capital was needed for materials and labor, to carry the processes of manufacture through their many stages before the product could be put on the market. From the necessary increase in the size of the producing unit arose the perception of the economies of production on a larger and larger scale. These economies involve the purchase and transport of large quantities of raw materials, the utilization of more highly developed machinery which can save labor only when a large output is secured, the direct saving of both manual and clerical labor, the increased efficiency of management, the utilization of waste products, the carrying-on of repairs, provision for storage, the employment of inventive and artistic ability. ${ }^{x}$ And beyond all of these economies of production on a large scale it has been found that the large business enjoys superior competing power. The possession of a comparative monopoly of employment in a given trade for a given locality makes possible the depression of wages, at least for a time. But the single great industry is often more easily coerced by organized labor. Because of the economies of production on a large scale, a good rate of profit may be realized at a price which will drive smaller competitors out of business, after which the price may be raised again without fear of renewed competition; for a possible competitor of equal power would know that the keen competition which must follow his entrance into the business would depress the rate of profit below that obtained for capital generally. Thus, the conditions of free competition which were so essential to the earlier stages of great industry that they were taken as the ideal for all social progress are found to be self-destructive-leading to a condition in which labor is so immobile that it can not profit by the competition of employers, capital so fixed that it can not freely seek its maximum profits, the public so dependent upon sole producers that it may, within certain limits, be exploited without remedy save in the settingaside of free competition.

On account of these advantages, the size of the producing sobson, The Evolution of Modern Capitalism, I17, I18. 
unit tends to become larger and larger, while the number of such units becomes smaller, ${ }^{\mathbf{r}}$ until finally a single one gains possession of the entire field. Individual ownership passed into copartnership, copartnership into the stock-company, and the latter is now passing into the so-called trust. These changes in the size of the average manufacturing concern have brought about two important changes in their character.

In the first place, the manager has been pretty completely differentiated from the capitalist. Since no individual or small company of individuals could furnish the capital or incur the risk involved in the greater enterprises, it has been necessary for the many owners of capital to put the actual management of industry into the hands of salaried officers who may not own any of the capital. The supply of this managerial ability for great enterprises is relatively scarce, and hence must be liberally compensated. The requisite ability seems to appear about as the development of industry calls for it, but cases are not unknown where large industries have broken up because of the lack of it, and it may be questioned whether managerial ability can be found that will enable any great industry to expand to its ideally most profitable proportions. The fact that the manager receives a princely salary and owns stock in the company which employs

I In the United States the number of industrial establishments of all sorts increased from 123,025 in $185^{\circ}$ to 512,339 in 1900, while the capital employed increased from $\$ 533,245,35$ I to $\$ 9,835,086,909$. - Census, r9oo. But these statistics have little value because they include the cobbler shop employing a single workman and the great steel plant which employs thousands. In the last census, also, establishments were catalogued as distinct although it was known that many of them were under a single ownership.

As illustrating the tendency toward large-scale production, the same census shows that the increase in horse-power during the preceding decade was 89.8 per cent., while the number of establishments using power increased 68.2 per cent.

The same census reports 185 industrial combinations having a total capitalization of $\$ 1,436,625,910$ and employing 400,046 wage-earners; but this class does not include the large concerns which were not formed by a combination of existing independent plants, nor are the combinations in the form of securityholding corporations fully treated. During and since the census year, the consolidation of independent producers has proceeded rapidly. 
him does not in the least destroy the thoroughly social character of his function. He manages the capital of other people who appoint him as their trustee; he directs the labor of individuals who are legally and self-consciously free; he produces a utility in response to a demand from a public which supports the whole enterprise. If his position enables him to manipulate the stock, or oppress the laborers, or exploit the consumers, it is only because the industrial development which has produced him has not yet been fully consummated. Great fortunes are now being made by the manipulation of stocks, rather than by production; and the man who can secure the support of a majority of the stock feels that he has a right to exploit the minority interests and, finally, after making a fictitious showing of earning power for the company, to sell the majority stock under false pretenses to the investing public. The law does not yet give adequate protection against such malfeasance; but the time will come when the practice of electing managers by a vote of a mere majority of the stock-a survival from the time when the relatively large average holding in a relatively small, local company enabled the stockholder to exercise a real control over his elected manager-will give way to some suitable form of trusteeship which will be responsible to all of the capitalists. The managers who claim the right to determine arbitrarily the conditions of the labor contract are confronted by labor organizations which claim the right to dictate both the terms of employment and the discipline of the workshop. It is inconceivable that this tension is to be permanent. Some way will be found by which collective bargaining can be made effective, and at the same time efficient supervision and the proper adjustment of labor-cost to market price maintained. The managers of industries that have become virtual monopolies may run up the prices on commodities of general consumption and subject the public to considerable temporary hardship. ${ }^{x}$ Some regulation of prices without too great public interference with

x This charge can seldom be made with justice against the so-called trust. It is a real evil chiefly in the field of the natural monopoly, especially in the supply of public utilities in the large cities. Nevertheless, the power to exploit the public alarms many conservative citizens. 
the private management of business seems entirely within the range of possibility. On the whole, these evils may be regarded as incidental, ${ }^{x}$ not essential to the present industrial system.

The other change that has occurred in the industrial world has already been suggested. The immensity of modern industrial undertakings necessitates the employment of the surplus wealth of the entire community. No small company of men can furnish the requisite amount of capital. The capital invested in the railways and great manufactories-those approaching or realizing the "trust" form-must aggregate in the United States something like $\$ 10,000,000,000$, while the small factories and mercantile establishments not wholly owned by their operators must also represent an enormous total, and the floating capital needed by industry still more largely augments the whole. This capital can not be supplied by the managers of industry, nor even by those more conspicuous capitalists who manipulate stocks and shape policies. These very wealthy men may own a large share of the whole; well-to-do people who take no active part in business management also own a large share; while the better class of artisans likewise supply hundreds of millions of capital, especially of that floating portion which is supplied through the banks for the payment of their own wages and the purchase of materials. Modern capitalistic production is essentially co-operative. Again it may be claimed that the very great evils connected with stockwatering and speculation are but incidental to the system and may be remedied without interfering with the general character of the system itself.

The wide ownership of the means of production, while not necessarily an indication of a tendency toward complete collectivism, is nevertheless an indication of the social character of production. Practically all of the available wealth of society is now directed to productive uses. If a completely socialistic scheme could be carried out, it would be necessary, unless society

I My reference to an evil as "incidental" does not imply that it does not require serious consideration. I mean that it is possible for the system on which it is fastened to exist in its essential features with the evil removed. 
should confiscate all private property now held, to obtain the capital from those who are now furnishing it. If public bonds should be given to the present capitalists, it is difficult to see how the new system would differ materially from the present one stripped of its incidental evils-except that the bonds might be made non-interest bearing. In short, there has been developed, along with this great industrial system, a banking and credit system through which all wealth not reserved for consumption may be made available for production. Before the Industrial Revolution, banking was of very minor importance. In 1750 not more than twelve banking-houses existed outside of London, and within the city there were few of importance. The London clearinghouse was not established until 1775 . At present the enormous banking interests of all civilized countries and the equally important credit arrangements by which capital may easily be turned into the industries which need it, make possible the employment of the resources of the whole society in the production of the goods desired by society.

A further indication of the organic character of society is the fact that the individual is compelled to serve society in caring for his own interests by turning back into the productive processes much of the profit derived from invested capital or managerial ability. The incomes of the wealthy are largely turned back to productive purposes, making possible the enlargement of plants, the employment of more laborers, the increase of production, the cheapening of prices. In many directions the consuming capacity of the individual, rich or poor, is limited. Extravagant consumption is possible to a certain extent, and is, perhaps, a growing evil, though the Newport crowd may be offset by other millionaires whose plain living is carried to the point of parsimony. But the total waste of the rich is probably a small item which, if saved and distributed throughout the whole society, would be of little consequence. ${ }^{x}$ The chief use which the wealthy capitalist can make of the income of his capital is to add it to his

$x$ Cf. Davenport, Outlines of Economic Theory, 320-24. This writer quotes Charles Booth to show that in London only sixty thousand persons 
capital and employ it in the production of still larger quantities of the goods of common consumption. The evil of the possession of great wealth lies rather in the unworthy social prestige and opportunity for corrupt use which its possession gives to the rich than in the greater amount of goods which the rich consume. It is possible that a continued growth of democratic feeling accompanied by a general improvement of the material and intellectual condition of the masses will take away the satisfaction and social prestige which now come from ostentatious consumption, and that a sounder political consciousness on the part of the masses will render corruption impossible. If the more extravagant follies of fashion could be avoided, the influence of the rich in setting standards for reasonable emulation might be altogether desirable. Certainly many of the world's chief advances in culture have been brought about in this way. However this may be, these evils connected with capitalism should not blind us to the real efficiency of our present social system in harmonizing individual and social interests by controlling all surplus wealth in the interests of society. And since the deeper currents of the industrial movement are so thoroughly social, it may be wholly undesirable to attempt to change them in the direction of an assumed perfect "socialism." A more self-conscious collectivism may be found to be desirable; but when constructing our ideals we should not overlook the fact that the present individualism is essentially social. Indeed, it may be questioned whether a socialism that is conscious of itself is as desirable as a system which secures all of the values of collective production without burdening the public mind with the care of the machinery. If the socialists tell us that the "trust" is a step toward socialism, may we not reply that the socialism which will be realized will be far different in form from their utopia? When the process of adjustment to the rapidly changing conditions produced by the progress of the present era shall have been accomplished, the profits from the promotion, management, or manipulation of gigantic industries

in all enjoy the luxury of as many as four servants to the family, and "with less than half of these is the number of servants greater than that of those they serve." 
will doubtless be reduced to a normal basis, ${ }^{\mathrm{x}}$ which means a reduction toward the vanishing point. It is at least conceivable that the best possible system is one in which the adjustment of individual and social interests is such that all of the possible advantages of collective control of industry can be secured automatically by allowing the individual to pursue his own ends. ${ }^{2}$ This is not a plea for the old doctrine of laissez faire, for the latter required the toleration of the serious incidental evils of the competitive system as well as the maintenance of the essential features of the system itself.

Labor.-The very conditions which furthered the Revolution in England raised the labor problem at an early period. England was ripe for industrial expansion because she could command immediately a force of laborers such as no other nation then possessed. The growth of large farms resulting from the profitable nature of sheep culture and, later, of agricultural operations on a large scale, had driven large numbers of English peasants into the towns. The passion for land, the desire on the part of men who had been successful in commerce to secure social standing by becoming land-holders, had made it impossible for the agricultural workers to obtain property in land, and hence they had little interest in improved methods of agriculture; whereas, in France and Germany the interest and property of the peasants in the land made it difficult to detach them from it when factories were established. The attempt to introduce the agricultural improvements, together with the operation of the Poor Law, incited "the large proprietors and farmers to rid themselves of all superfluous population in the rural parts, and accelerated the migrations into the towns." A large supply of cheap labor was thus secured for the factories of Lancashire and Yorkshire. Meanwhile, the exhaustion of the French wars and the political disorders following them rendered competition impossible on

× Cf. Newcomb, "The Concentration of Railway Control," Annals of the American Academy of Political and Social Science, XIX, 89-107, on the fall of railway profits.

2 Cf. the writer's article on "A New Plan for the Control of Quasi-Public Works," in American Journal of Sociology, III, 837-47. 
the Continent; and the task of settling new lands and the profitableness of the extractive industries retarded the development of American industries until after the middle of the nineteenth century. ${ }^{x}$ American products fed the factory population of Great Britain and supplied the factories with much of their raw material, while the marine of the latter country was able to transport all of the supplies drawn from all parts of the world. All circumstances, including some of England's economic blunders, seemed to contribute to the development of her new industries.

The general features of the labor problem as it arose in England and afterward spread to most other countries need no detailed statement for our purposes. The rise of the new towns, the influence of the Poor Laws, the evils of child labor, the lowering of the standard of living, the violence of the laborers, the agitation for reform and the passage of the first factory acts, the repeal of the protective tariff, the origin and growth of tradeunionism-these have been so fully treated by numerous works that an attempt to describe them here would result in a mere repetition of facts with which every casual reader of industrial history is familiar. The serious evils of child labor, unsanitary workshops, and pauperizing benevolence, while they seemed unavoidable to many employers, have yielded to a method of treatment which may be applied everywhere, provided the reforms are not attempted too rapidly. But some of the results of the concentration of laborers in large numbers, the nature of their employment and their wage relations, require consideration in this connection. These introduce new conditions which can not be changed by any reforms that leave the industrial system unchanged, while the evils which first attracted exclusive attention are, in the long run, of minor importance.

The massing of laborers for the carrying-on of large industries resulted, in the end, in the development of a consciousness of power and the organization of means for the attainment of class ends. Men having common interests, when thrown together,

Cf. Hobson, op. cit., 76, 77. 
are bound to form associations. Since the laborers had been completely differentiated from the masters, these associations necessarily differed from the old gilds which had existed in the interest of the whole industry. They were organized to wrest from the employers larger concessions, regardless of the more remote interests of the consumer. The success of the organizations in shortening the labor day and in maintaining a higher level of wages is sufficient excuse for their existence. That the employer's profits are largely the result of superior competing power, does not prevent the workmen from raising the general level of wages on the basis of which competition is to take place. Even where the conditions of an industry do not admit of an increase of prices to the consumer, a gradual increase of wages may lead to increased efficiency, to the unmixed benefit of the workmen. If it can be shown that the workings of economic laws would result, in the long run, in substantially the same benefits that are secured through organized endeavor, there is still ample justification for the existence of the unions in their ability to modify the tension at the various stages of the process of improvement.

Still more important than these immediate advantages to the working population is the translation which the movement gets in consciousness. The complete division of labor and the bringing of those who are carrying on various interrelated activities into intimate relations with one another, results in the strengthening of the democratic tendency which has already been described. Whether the movement takes the socialistic or the trade-union turn, it always means the appreciation of the common man in his functional relationships. In those countries where other causes have contributed to the development of the democratic feeling, the industrial movement greatly strengthens that tendency, and brings to consciousness the importance of social co-operation which was overlooked in merely political democratic movement. Where the democratic feeling had been feeble, the industrial movement has always stimulated it.

Now while this consciousness of the social worth of the common 
man may result in much blindly selfish agitation, the outcome is, on the whole, a distinct social gain. The amelioration of the lot of the workingman is a desideratum, but the development of this spirit is far more important than temporary material gains. Christian socialism, profit-sharing, and other benevolent programs $^{x}$ are impracticable in the light of this movement. Those writers who commend such efforts, though alive to the evils of the present labor conflicts and actuated by a sincere desire to improve the condition of the laborer, miss the whole spirit of the movement. They hold up as an ideal the old feudal relation. The employer should feel his responsibility toward his workingmen; should provide them regular employment, pay them liberal wages, look after their moral and physical well-being in every possible way. The employee should show his gratitude to his benefactor by faithful service and willingness to go beyond the letter of his contract. The substitution of the "cash nexus" for the old personal relationship of master and servant has been deplored by earnest men from Carlyle to the present time. There was, indeed, something beautiful in the feudal relationship at its best. The ideal of the strong, capable leader protecting those who are dependent upon him, and of the faithful follower loyally seeking to advance his lord's interests, is not without its attractiveness. But the nature of things is against the restoration of this order of society. The spirit of the labor-class movement is wholly against such a backward step. At their best, the tradeunionists regard social recognition and independence as more important than material betterment. They do not want benevolence or charity; they will have "justice." While their conception of justice in the concrete may often be extravagant, they are right and the Christian socialists are wrong. It is better that the tension between capital and labor should continue than that a return should be made to some form of status. While the friction causes misery and disorder, the outcome will represent a distinct

I German state socialism, so long at it is in the hands of the present ruling classes, is very similar to Christian socialism. It is tolerated by the social democrats only because they hope ultimately to secure control of it. 
advance. So, one result of the Industrial Revolution has been an intensification of the democratic tendency, coupled with a new sense of class solidarity.

The old system is gone never to return. The separation lamented by Carlyle was inevitable; but we can now see that it was not wholly evil. A terrible interval of suffering there was, indeed, when the workman, flung off by his master, had not yet found his feet; but that is passing away, and the separation is recognized as a necessary moment in that industrial progress which enabled the workman to take a new step in advance. The detested cash-nexus was a sign, not of dissolution but of growth; not of the workman's isolation but of his independence. If, however, Carlyle was mistaken in denouncing the Revolution, he was right in proclaiming that isolation is not the permanent relation of human life. If history teaches us that separation is necessary, it also teaches us that permanent separation is impossible. The law of progress is that men separate; but they separate in order to unite. The old union vanishes, but a new union springs up in its place. The old union founded on the dependence of the workman disappears; a new union arises based on the workman's independence. And the new union is deeper and wider than the old. For workman and employer parted as protector and dependent to unite as equal citizens of a free state. Democracy makes union possible-creates its initial conditions. ${ }^{x}$

The solution of the tension between capital and labor, leaving out of consideration for the time the possibility of socialism, seems to be in the direction of the organization of an entire industry on the principle of the gild, though, of course, on a much freer plan. There are four conceivable objects for which the trade-union may work. The first and most immediate of these is to force the employer to give up a part of his profits. This can not be done successfully for a long period in any industry. Under ordinary circumstances in competitive industries it can not be done at all. Competitive profits are a differential. The marginal employer obtains no pure profits, but the union will enforce the same wage scale upon him that is maintained in the more favorably situated establishments. Therefore, unless the price can be increased, the increased cost of production will force him out of business. The price remaining the same, the nonmarginal employers could pay higher wages; and the supply

Toynbee, op. cit., 199, 200. 
being curtailed by the retirement of the marginal employers, they could raise the price slightly and maintain their old profits even with higher wages. But the retirement of the marginal employers would throw so many men out of work that the higher scale of wages could not be maintained. Where monopoly profits are obtained the union may force the monopoly to share these with labor. But the capitalistic monopoly, at least, endeavors to keep the price down. If it does not do so, competition is likely to arise. When well established and well managed, the capitalistic monoply probably finds its chief advantage in steadier business conditions, rather than higher profits. If it keeps up its profits in dull times, when the ordinary establishment is running without profits, these can not be encroached upon by labor, for there are then so many men out of work that the union can not maintain its control. If the monopoly obtains extraordinary profits in good times, these may be cut into by labor, just as the extraordinary profits of competitive industries may be. But at all times the monopoly employer óccupies a strong position in dealing with labor, and is not likely to lose in wages what he gains from monopoly control, except in times of exceptional business activity. It should be noted, also, that numerous competing industries may enjoy exceptional profits during the periods of great activity. If new capital can not flow into the industry immediately, even the marginal producer may obtain high profits for a time. Under these circumstances, labor is bound to demand and to receive higher wages, and the increase will come out of the profits; for the price is already considerably above the marginal cost of production. On the whole, then, it seems that organized labor can not gain permanently at the expense of profits, though the temporary gains during periods of great business activity may be considerable.

A more promising field for trade-union activity would seem to be in the direction of increasing the efficiency of labor. This is seldom, if ever, a conscious aim of the modern labor organization. Indeed, the union usually discourages increased efficiency. It is assumed that there is a given amount of work to be done and that if those who are employed do not work too rapidly, the job will 
last longer or will furnish employment for a larger number of men. In either event, the increased demand for labor is counted on to raise wages. Some of the wiser labor leaders have mastered the economic facts, but the average workman believes-and the average union endeavors to give force to that belief-that the interest of the laborer is secured by liniting the output. Of course, the laborer must be paid from the product and must lose in the end if the product is diminished. However, while the conscious endeavor of the union is not to increase the efficiency of labor, this result has often been accomplished indirectly by the unions. In so far as the material condition of the laborer is improved, his standard of living raised, he is likely to be more efficient. Privilege does not often understand its own interests. Higher wages or shorter working-time may so increase the efficiency of labor that the cost of production is actually lowered; but these are most likely to be introduced as a result of a struggle between organized labor and the employer. At least, they are most likely to be secured as a result of joint bargaining.

A third object of the labor union might be the exploitation of unorganized labor. The older trade-unionism probably succeeded largely because there was so much labor that was not organized. If profits can not be encroached upon and prices can not be increased, wages in certain trades may nevertheless be increased, provided certain other workmen can be forced to accept lower wages. It has been to the advantage of the skilled mechanics in America that much of the rougher work has been done by immigrants who were accustomed to lower standards of living. The present tendency, however, is to organize all grades of labor. First in America through the Knights of Labor and later through a federation of all trade-unions, the attempt has been made to set the whole laboring class over against the employers and consumers. There is a feeling of class solidarity among the laborers that forbids the strong to exploit the weak. The motive of the labor leaders in organizing the workmen who are still outside of the unions is probably not disinterested. Believing, as they do, that labor may gain at the cost of the employer or the consumer 
they feel that the opposing forces can be defeated more easily when the labor army is solidly organized. There is usually nothing noble in the sympathy strike or the boycott of goods produced by industries in which strikes are in progress, though class feeling sometimes dictates such united action where there is nothing to gain. If permanent gains are to be secured from the employers as such, there is doubtless a considerable advantage in the organization of the whole labor force. The sympathy strike and the boycott may sometimes be employed effectively; but, aside from their bad effect on the public, whose moral support is usually needed, the loss in wages is so large that sufficient contributions can not be made to those immediately interested in the strike. A universal strike is likely to prove a failure, but the strike at some strategic point, supported by other workmen still in receipt of regular wages, is likely to succeed. This has been the policy of the coal-miners of the United States, who, concentrating their attack on the anthracite employers while nearly all other miners remained at work, were able after victory in their first struggle, to make successful demands upon employers in other coal fields. In this case, however, the stubborn opposition at the first point of attack prevented operations elsewhere until a period of remarkable demand for coal was drawing to a close. The permanent results of this whole series of campaigns will probably be much below the expectations of the workmen and the belief of the public. Yet the plan of attacking the employing class piecemeal, instead of as a whole, must be commended as the wiser policy. But aside from all of these advantages of the working-class movement as a whole, the narrow and possibly more selfish trade-unionism proper would secure more solid gains for the members of the stronger crafts.

The fourth possible object of trade-unionism is that suggested above, namely, the union of both workmen and employers to advance prices to the consumer. The mere mention of such a policy suggests its difficulties. Prices can not be advanced arbitrarily without checking consumption. Yet if a well-managed monopoly may establish a price which is neither so low as com- 
petitive production would bring about, nor so high as a shortsighted manager might obtain for a part of the product, but at the level which yields the maximum profit; there is no reason why a monopoly of labor and a monopoly of capital night not unite in establishing a price which would yield the maximum returns to both. The strong trade-union is able to meet employers with a consciousness of power and a feeling of equality, and the two parties can agree upon a labor contract the cost of which must be charged to the consumer. Some trades, notably the building trades in certain large cities, have obtained such recognition. Where the costs of production are not recklessly increased, the plan may be successful. If society demands a given product, it seems but proper that those who are engaged in its manufacture should receive compensation that does not fall below a certain minimum fixed with reference to the general level of wages and the conditions of business. The determination of such a wage involves delicate computations which it is perhaps not yet possible to make, but the method being adopted, experience will doubtless open the way to the settlement of details. The extraordinary demand for buildings in large cities has enabled contractors to accept an extraordinary wage scale and to make successful bids on such a basis; but even there the demand has often been so perceptibly checked that the contractors no longer accept the situation as tolerable. When the leader of the mine-workers suggested, as reported, that the price of anthracite coal be increased to cover increased wages, it was stated that prices were already as high as the demand would stand; and this was undoubtedly true, for the substitution of higher grades of bituminous coal for anthracite had already placed the latter industry in such a position that it could barely keep the prices high enough to cover costs of production, except in years of exceptional general prosperity. The peaceful relations between British manufacturers and the trade-unions have probably been responsible in part for the check on the foreign trade of Great Britain, for the costs of production make it impossible to compete with German and American manufacturers in markets where a monopoly was formerly enjoyed. It is, then, only within narrow 
limits that labor may gain at the cost of the consumer; but within those linits agreements may be reached whereby wages, hours, and conditions of labor, and the internal control of industry shall be settled without friction. Thus,

boards of conciliation may grow into permanent councils of employers and workmen, which, thrusting into the background, but not superseding, trades unions and masters' associations-for these must long remain as weapons in case of a last appeal to force-should, in the light of the principles of social and industrial science, deal with those great problems of the fluctuation of wages, of overproduction and the regulation of trade, which workmen and employers together alone can settle. ${ }^{x}$

These, then, are the possible gains to labor from organized effort: the wresting from employers of part of their profits, where the latter do not have for a given time or industry a marginal point of disappearance; the increase in efficiency of labor by raising the standards of living by a policy of opportunism; the increase of the wages of organized labor by the depression of the wages of the weaker trades; the increase of wages at the cost of the consumer.

The evils of inequitable distribution are very great; and we must regard with favor any movement that can secure for the mass of the industrial population a larger share of the goods of life, or enable them to profit as workers by the substitution of mechanical aid for human power in the freeing of a greater portion of their time from the monotonous round of ordinary labor. But a little reflection must convince us that neither trade-unionism nor socialism can secure these results in very large measure. We have no mathematics by which to determine what is the actual product of the labor element in industry; ${ }^{2}$ and, besides, it is not a share of the product, but of the values created, that the producers claim, and the determination of values rests with all consumers as well as with the particular producers concerned. Further, as we have seen, there is only a remote connection

× Toynbee, op. cit., 201.

- Clark, The Distribution of Wealth, proves only that both capital and labor are productive. His theoretical separation of the respective shares could not be applied practically to any actual case. 
between wages and profits. It is only at the expense of the consumer that wages can be increased; and when such an increase occurs, not only is there danger that the industry may suffer, but it may happen that the wage-earners, being the chief consumers, may lose in real wages as much as they gain in money wages. So, trade-unionism is at best opportunism. Its benefits to many thousands of workers have been very great; and, it may be added, its injury to business has likewise been great. But its ideal is a temporary ideal, and its solution of the labor problem is not the ultimate one. Where competition is relatively important, either in actuality or potentiality, profits will fall, when the industry has become fully established, until they approach the vanishingpoint. Gains may be made when managers and operatives unite in some such way as has been indicated above, but this union involves the willingness of the public to pay higher prices, which, in turn, usually means that less can be expended on the products of other industries whose internal condition is equally in need of improvement. Granting that the demand in a specific case will remain the same, there will be a diminution in the demand for the products of other industries and a consequent dislocation in distribution elsewhere. The best work of the trade-union has been the equalization of wages in various centers of the same industry and the prevention of local exploitation of labor by overreaching employers, and the gradual raising of the level of wages in co-operation with the employers. ${ }^{2}$ If the ideal of tradeunionism can be realized and all labor drawn into its ranks, it

Except where a single trade is strongly organized and can secure an advance while other trades stand still.

2 In the above discussion I have not dealt with the question of increasing wages at the expense of rent or interest. Rent being a differential not depending upon the work of any given laborers, it is impossible for labor as such to reach it, though it might be possible and desirable for the community as a whole to appropriate it. Interest being the payment necessary to draw the marginal capital required by industry from consumption to production purposes, it would be impossible to increase wages by reducing interest. Even under a socialistic régime, if wages should, for the moment, absorb the whole product of industry, it would be necessary to pay interest in order to draw consumption wealth back into production. 
must become, not a trade union, but a union of capital and labor. For if the time were come when capital was forced to show its books to labor and prove that labor was getting all the share the wage-earners could in reason or expediency claim, then to persevere in asking more would be suicidal; and the only form of union left would be that of capital and labor working together to produce the largest total result. ${ }^{x}$

Consumption.-After all, the controlling influence in producion is consumption, and the question of real wages is much more important than that of money wages. It is doubtless because the productive processes have been so completely socialized that economic theory which, during the earlier stages of industrial expansion, had found its chief interest in phenomena of production, has shifted its interest to those of consumption and distribution. The first tendency away from almost exclusive emphasis on production is found in the socialists. Their interest is in the problems of distribution, because the inequalities in compensation seem to them to be the greatest of social evils, the general social interest in the industrial processes not appearing to be worthy of notice. No desire is expressed for a change in the system of production that now prevails. The evil results to the laborer of minute division of labor are recognized; ${ }^{2}$ but the remedy is to be found, not in the abandonment of division of labor, but in preventing the capitalist from wresting from the laborer that portion of the product which represents his surplus labor. ${ }^{3}$ Production has already been socialized through the division of labor and the employment of capital. If it is true, as held above, that modern productive processes draw back into themselves a great part even of the product secured by the owners of capital, then the system is about as completely socialized as would be possible under any control. True, the wastes of competition and of the fitful consumption caused by the display of spending-power still remain, but these are rather external to the productive processess than essential elements in them; and the former of these is being eradicated in so far as it has to do with

I Smart, Studies in Economics, 3 I 7 .

2 Marx, Capital (Humboldt ed. ), 218-20.

3 Ibid., 33r, $33^{2}$. 
production itself. The evils, then, seem to be on the side of distribution instead of production. The demand is for the "whole produce of labor," and the control of the means and methods of production is desired simply to secure the equitable distribution of that product.

Many English and American economists who uphold the present system likewise lay the chief emphasis on the subject of distribution. ${ }^{x}$ It is assumed by some that consumption is a purely individualistic phenomenon. It is but natural that so much attention should be directed to the solution of problems of distribution. When production was assuming new forms and new proportions, a system of economic theory was developed, starting from the point of view of the manager of industry and attempting to show how his interests could be best advanced. It was not strange that these economists were men who lived in close contact with the new industrial forces. Now that strong practical interests center in the problems of distribution, it is but natural that writers who live in the midst of the conflict should work especially on the theory of distribution. No system of economic theory has been based upon distribution, but the subject occupies a large place in economic discussion. Problems of consumption may be vastly more important than those of production or distribution; but employers and workmen represent definite organized forces, while the interests of the consumers can not be definitely organized for the active pressing of claims. Even in current discussions of capitalistic monopolies, more attention is usually paid to the competitor who is crushed or to the workman who is exploited or thrown out of work, than to the consumer who suffers from increased prices. The phenomena of consumption have been give a central place in economic theory first by the Austrian writers who are spectators from a distance of the modern industrial processes. This is undoubtedly the more adequate point

I E. g., Clark, op. cit. This writer, however, admits that consumption may have an important influence on production, p. 23. When the chief emphasis is laid on distribution, it may still be possible to regard that subject as a sub-division of production. 
of view for the treatment of economic problems. ${ }^{x}$ It recognizes the organic relation of the whole industrial process to the whole social life. It assumes that the interest of society in the supply of its wants and the maintenance of its wealth must take precedence of the interest of the capitalist or manager in his profits or of the workman in his share of the dividend. It is because production has been so completely socialized that attention has been turned to the problems of distribution and consumption, and the former of these new points of view represents simply a haltingplace on the way to the latter and more organic one.

While production has been pretty thoroughly socialized, consumption has been much less completely socialized. Distribution is not co-ordinate with these, but is an intermediate process which becomes normal in proportion as the other two are socialized. Except for minor perturbations which trade-unionism and palliative legislation may remedy, distribution becomes economically automatic when production and consumption are normal. Therefore, the great problem of social-economics is the socialization of consumption.

It is not claimed that modern consumption is lacking in this social character, or that it may be improved to any great extent by conscious effort. Indeed, the greater part of the output of modern industry destined for actual consumption is of a character to meet our demands; and therefore the condition of all classes of society except the residuum is hopeful. By socialized con-

I I have no doubt that the philosophically adequate statement of economic theory must include both consumption and production, both supply and demand, for the two are reciprocally related. I mean by this that neither consumption nor production must be taken as statical, the other being taken as an independent variable. Both are dynamic phenomena, and both must be taken as reciprocally cause and effect, starting-point and terminus. The Austrian theory is probably as defective logically as that of the Manchester school; but practically it seems more nearly adequate to regard the economic processes in the light of the social demand proceeding from consumption than from the point of view of the motives of the leaders of production or of the demands of the laborers. My discussion in this chapter indicates the social nature of both production and consumption, but this is not the place for an attempted statement of economic theory which would comprehend the whole economic activity-nor should I feel able to make the statement, had I the space. 
sumption is meant the consumption of goods which minister to the most essential functions of social life, and their consumption by all classes of society. Food, clothing, dwellings, and all things necessary to a wholesome physical existence are, of course, of primary importance. The consumption of these may be said to be social when all grades are within the reach of all classes of society-not that every man will enjoy the same comforts, but that every man may improve his consumption in every direction by steady progress from the commonest to the richest products. Commodities that satisfy æsthetic, intellectual, religious, or any other needs also have social value, may, indeed, be chiefly social in their character. It is very easy for the person who has an abundant income to fall into casuistry in deciding upon an expenditure for consumption; for extravagant and aristocratic consumption includes food, clothing, shelter, books, pictures, sermons, songs - the very classes of utilities which in other forms may be regarded as thoroughly social, that is, democratic. In general, it may be said that socialized consumption includes those goods and services which, without inducing manifestly pathological conditions, may be shared with the largest number of our fellow-men; or, if not immediately appreciated or attainable by them, are not so remote from their present consumption as to be beyond their possible tastes or hopes. This does not mean a dead-level of consumption, or the impossibility of certain persons setting the pace for the rest of society, but it would preclude the private palace when the masses could have nothing better than hovels. So, bread is more social than canaries' tongues, beer than champagne, woolen cloth than sealskins, a public art gallery than a private collection.

As contrasted with that of any previous society, our consumption is pre-eminently social. Our production has a variety and richness never attained by that of any other society. Not only are the common necessaries of life produced in great quantities, but those intended only for the wealthy are of relative unimportance. Not only do most great capitalists turn most of their income into capital, but they employ this capital in producing 
utilities which everybody consumes. Some commodities of barbaric richness are produced, but between these and the commonest goods there is the greatest variety of products running by insensible gradations from the lowest to the highest points on the scale. It is due to the plentifulness of the commoner products that our laboring population enjoys so many of the comforts of life; and it is due to the variety and quantity of the intermediate products that they may advance their standards of living so steadily. The increase of money wages by strike or peaceful bargaining would be of no advantage, could the money not be turned into real consumption goods of so many varieties and grades.

It will be remembered that throughout this essay it has been held that the freedom of the laboring masses depends upon their ability to control either the technique or the product of their labor, or both. Of these two the latter is the more important in the long run. The former is usually important at the beginning of a new stage of development, because it frees the artisan from past control and gives him a sort of monopoly compensation that carries him far beyond his former station and enables him to adopt a new standard of living from which it is difficult to drag him. This improvement belongs to a particular class of workmen at a particular time. It can not be universal, though it may be so widespread that a very large number of laborers may be raised at the same time. It is not democratic, but may result in the formation of so many new aristocracies that aristocracy itself is cheapened. But every technique tends to become common property, in spite of restrictive measures; and efforts to retain control of it by artificial apprenticeship rules can not be permanently successful. The best that can be done by the labor association is to keep such a control of the conditions of their trade as to prevent sudden inundations of new hands and temporary disturbances of the labor market. Efforts to enforce further restrictions at the present time are of little avail, and no technique can long be monopolized by a few under modern conditions of industry. In the end, workmen must expect to see new recruits enter 
their ranks, in part causing an expansion of the industry, in part cutting down the exceptional money wages of those who formerly controlled the field.

The control of the product of labor, on the other hand, can be retained, if the commodities consumed by the laborer remain plentiful; and as they become more plentiful and as other consumable goods but little in advance of his existing standards are likewise plentiful, his real wages are pretty sure to rise. The product, in the sense here intended, is the value created by the laborer. In our times the laborer has kept or extended his control over this value through the character of our general consumption, rather than through his control of money wages by associated effort. Wages have tended to rise and prices to fall; and the abundant stimuli to an improvement of the standards of living have prevented an undue increase in the size of laborers' families during times of prosperity. As a matter of fact, our industrial development has been of such a character that the consumption of the masses has been the chief stimulus to production. The most important improvements are such as cheapen the products consumed by the laborer; the next, those consumed by the middle class; those which cheapen the products used by the rich have not been numerous.

Nearly all the large improvements in modern industry have depended for their success upon the creation of a wide market, appealing not only to those who have accumulated large fortunes, but to those who live more or less prosperously on the results of their labor. Under these circumstances we find an active competition both for the services of the laborer as a producer and for the money of the laborer as a consumer; especially the latter. ${ }^{x}$

Producers in general are quite as much interested in the increase of the spending-power of laborers as particular producers are interested in reducing their labor costs. In so far as consumption guides production in this direction, the rich find themselves compelled to turn back their surplus incomes into productive enterprises which satisfy the demands of the poor.

Now, while consumption has become so generally democratic,

I Hadley, Economics, 320. 
as compared with that of previous societies, there is still room for improvement. A growing tendency among the wealthy toward the indulgence in decadent luxuries and the employment of lackeys, imitated more or less by the middle class, and the overcrowding of clerical and professional ranks by persons who might better be producers of commodities, are sufficient evidence that consumption is not wholly socialized. A close analysis of our expenditures shows that a large proportion goes for things whose real usefulness for furthering and broadening life may well be questioned. ${ }^{x}$ Whether there is a field here for conscious reform may be doubted, but it is a field worthy of reform effort. ${ }^{2}$ The chief hope is in the development of higher ideals through the efforts of those who serve as public teachers and examples. It may be brought about to some extent by the action of the State. Sumptuary legislation is not at present a popular device, and it is liable to great abuse; but a tax upon extra-unsocial consumption might be levied with advantage to society as a whole, and the democracy may be depended upon to adopt such a measure if ever it awakens to its possibilities. Sumptuary laws were a failure in the Italian republics because they were criminal processes against those who indulged in luxuries at home, while the most profitable industries were those which supplied foreigners with the condemned articles. But since our legitimate consumption would still be so large, there would be relatively little difficulty in enforcing a law levying a tax on the production or the home consumption of unreasonable luxuries. In general, however, the greater profitableness of the industries which supply a wide demand may be depended upon to prevent the diversion of any considerable proportion of the capital and labor of modern society to the production of luxuries for the few.

As we have seen above, the demand for more direct social control of production has been chiefly in the interest of a more equitable system of distribution. Yet there is a growing demand that the service or supply of public wants be furnished efficiently

x Cf. Veblen, The Theory of the Leisure Class, especially chaps. iv-vii.

a Cf. Smart, op. cit., $263 \mathrm{ff}$; Hobson, op. cit., $368 \mathrm{ff}$. 
and at the lowest possible cost. Aside from the regulation of the sanitary condition of workshops and of the conditions of employment of the wards of the State, aside from attempts to promote harmonious relations between employers and workmen, there is a real interest in the regulation of the supply and the price of the more important utilities. Where competition seems effective, there is a disposition to trust it to bring about satisfactory results. Where competition seems to be absent, there is a demand for some form of public regulation. The removal of special tariff and patent protection, the enforcement of just laws governing common carriers, the extension of the common carrier legal prin. ciples to include all monopoly production for interstate commerce to the end that a common price may be fixed for the same article in all parts of the United States, ${ }^{x}$ the enforcement of publicity of those affairs of such producers as are of public interest, and perhaps such an income tax as would discourage exorbitant charges $^{2}$ - these are measures which would probably prevent exploitation of the public. The public is disposed to attempt to enforce some kind of competition to safeguard its interests, but it may well be doubted whether the present tendency toward the formation of great industries can, or should, be withstood. In none of this discussion is there a suggestion that the character of production should be determined by public authority in the interest of rational consumption. The education of the taste of the individual and the economic relation of supply to demand are probably the only forces that will ever be depended upon for this purpose.

This discussion has suggested the apparent tendencies and possibilities of the economic movement of the present time. Two other economic problems remain: the disposition of the unearned increment on land, and the treatment of those who perform no social function. The former of these requires no consideration here, in view of the general acceptance of the possibilities of some form of the "Single Tax," should action become necessary. At

× Cf. Clark, "Disarming the Trusts," Atlantic Monthly, LXXXV, 47-53.

2 A further statement of my views on this subject will be found in my article on "The Control of Trusts," American Journal of Sociology, V, 228-45. 
present there is little social interest in the evils of individual appropriation of the unearned increment, partly because the frequent transfers of land have left much of it in the hands of persons who receive no unearned increment, partly because of the plentifulness of land, especially in the newer countries, partly because of the solid social advantages that have been secured through private property in land. The other problem, the treatment of the idle, may not be entirely soluble. That portion of the idle class which belongs to the social residuum can be reasonably well handled by scientific philanthropy when public interest shall have been aroused. The residuum is a portion of the race which can never be expected to perform genuine social service or enjoy a normal social life. In any consideration of social evolution this class must be disregarded, save as some of its members may be redeemed, or as repressive or charitable measures are adopted with reference to the rest. The other idle class belongs to the other extreme of the social scale. It is not necessary that those who receive large incomes from invested capital should engage in actual industrial activities, but it may reasonably be demanded that they should render some real social service in proportion to the goods they consume. Without this the bond-clipper is a parasite. The remedy for this evil-which is not yet of large proportions-can probably be found only in the development of ethical ideals inconsistent with idleness. ${ }^{x}$

This long economic discussion has shown how completely society has organized its system of means. The concrete suggestions for the more complete socialization of the economic system may be of little value; but it is claimed that the general description and the statement of present tendencies are practically accurate, and that they justify the thesis that the integration of society has proceeded so far that the interests of the individual and of the whole have become essentially identical. The social-economic system is neither individualistic nor collectivistic: it is organic. It is a system of means through which society functions with reference to its ends -a system in which individuals and institutions are truly organs

× Paulsen, A System of Ethics, 533-36. 
of society and through which all the values of society are focused in the individual. It is not without its imperfections, but these are of minor importance when viewed in the light of the whole.

The structure which society has formed for the adaptation of means to ends is democratic. Many political problems await solution. Nationalism is a strong force in the world, and is not without its value in developing variety and richness for the whole social life. Neither is it without its evils in raising artificial barriers between communities that are essentially one and in causing conflicts among men who are essentially brethren. The chief cause of strife is over the methods of bringing outlying and probably unassimilable portions of the world under the control of civilized society. Nobody believes that a perfectly harmonious political system will soon be developed. Yet it is very patent that democracy is bound to control every state; that democracy, when it knows its interests, is bound to desire peace; that social ideals and economic interest are bound to promote peace and harmony among the nations; that, on the whole, dynastic and purely political ends can no longer permanently determine social action; that the most intense national spirit can not permanently prevent the co-operation of peoples whose interests are essentially the same; that, finally, the democracy which is the product of modern industrial influences is essentially social, co-operative, not anarchistic.

\section{SOCIAL IDEALS}

Leaving, then, the consideration of the political and economic phases of social life, it only remains to observe, in closing, the nature of the present social ends with reference to which these means are employed. Since the age of Descartes and Hobbes, the ideals which had come down from the Græco-Roman world and which had so long guided the social activities of Christendom have been virtually cast aside. The individual was freed from authority when those ideals were exhausted. From that time to the present the ideals of society have been developed in the process of social life itself. Necessarily, progress could not be as orderly and systematic as when it consisted in attempting to conform to 
the given ideals. The individual was freed, but he had so much to do that the problem of method became of supreme importance. This, first stated in theoretical terms by Descartes, has been worked out in a practical way amidst all the changes of commercial expansion, national organization, revolution of governments, and industrial developments.

In this modern development advance has been chiefly without great comprehensive social ideals. It has been characterized neither by inherited ideals nor by a conscious effort to project ideals for the guidance of the whole social life. As we have already shown, ${ }^{x}$ the ends of social endeavor were, during the period which was marked by the decay of the feudal system, either the political organization, as with the national politicians, or possessive wealth, as with the merchant burghers. The statesmen used industry as a

$\uparrow$ means to their end, while the merchant rulers used the political organization to serve purely commercial purposes. The two ends might sometimes be blended. Now, neither of these could be other than a proximate end of society. The real ends of society had to be something more ultimate than either. The industrial and commercial activity can but serve to get control of means by which to attain higher social ends; the political organization can be but the structure through which the means can be adjusted to the ends. When these are made the controling ends of social activity, certain great accomplishments may result, but in time they lose their vital force and undue friction, or even disintegration, ensues. Social action becomes blind and haphazard.

Yet in spite of this blindness in social action, we have seen that a very real social integration has been accomplished. The reason of this is that society is organic: it has a life which develops according to its own inner laws. Opportunism, haphazard efforts, may not produce the very best results. They may even lead to disaster. They may lead to social suicide, as, perhaps, through the religious persecutions in Spain; as they bade fair to do in the case of France after the revocation of the Edict of Nantes

I Vide supra, 273, 274. 
and again in the revolutionary period. But barring the great catastrophes which only conscious self-guidance can avoid, a society full of lusty vigor and equipped by the appropriation of the most vital elements of the great civilizations of the past might be expected to live and grow according to the law of its own being, and in its development to cast out the unassimilable elements which it had taken up in its blindness. An undirected activity has not prevented the integration we have described. This, however, is not the ideal method of action for any organization capable of self-consciousness. There is an ever-present danger which increases with the increasing complexity of the organism, not only that the social life will not be of the highest possible sort, but that it may disintegrate again under some of the tendencies toward degeneracy which are ever present. If ever there has been need of scientific social guidance, it is at the present time. No better evidence of this is needed than the many instances of friction which have been described above as connected with the very social movements which, it was claimed, are in the main in the right direction. Present tendencies may be trusted to work out the best results in the long run, provided the inharmonious minor movements do not gather such force that the whole structure will be shattered. While, therefore, the results of social development are sufficient evidence of the vigorous organic life, there is every reason for discarding the empirical methods which have worked such good results in so many instances, and for making a serious endeavor to discover the principles on which the social life may be guided to still higher attainments. If these can be given scientific statement, they will eventually be taken up by the social consciousness. It was necessary for the ancient societies to die before the principles of their civilizations could be abstracted and used as ideals. Modern society is more vigorous than any older one; and it has devised a scientific method which should enable it to learn the law of its own being. Empirical methods may be carried to a high degree of perfection; indeed, must be, before science can arise; but there is serious danger of retrogression in social organization unless scientific methods are discovered 
and applied. Modern society needs a ruling ideal, and this ideal must be the embodiment of the principles underlying the social life itself. The two proximate ends above mentioned are still in use as the ultimate ends of social endeavor. Different classes, or all classes at different times, are controlled by one or the other of these ideals; whereas the true end of social endeavor must be something other than either possessive wealth or the political mechanism. There is need of a science of social telics ${ }^{\mathbf{I}}$ to aid society to the acceptance of a comprehensive ideal that can guide its activity as the ideals of the Holy Roman Empire did in the Middle Ages.

Fortunately, this unconscious social development has evolved in its own processes the method by which its future ideals may be projected. Men's thinking has been reduced to a certain scientific order by the social movement. This was true to a certain extent of the earlier scientific conceptions, and it is true in a marked degree in the case of the scientific development of the last century. The Industrial Revolution made it necessary for men, especially when they had charge of large industries, to look facts in the face and to guide their actions accordingly. Man had to adapt himself to a large physical environment. The industrial life was falling into the form of wide physical causation. Man could choose only which of several forces should be allowed to work themselves out in his service; he no longer thought of creating forces. This change in the life of society necessarily had a great influence over men's systems of thought. Previously, the personal relation had constituted almost the whole order of society. The change of view in the industrial sphere forced men to think differently in all departments of life, since life itself is a unity. So, men have been insisting on introducing the idea of causation in the explanation of everything: they have not been satisfied except in so far as they have been able to bring their observations under the categories of the conservation of energy. The adoption of the machine has in every community preceded Sociology.

I A term suggested by Ward and most fully discussed in his last book, Pure 
the progress of science. The French continued longer to speculate upon the affairs which the English treated scientifically. Since the middle of the nineteenth century, there has been a growing dissatisfaction with the explanation of the world or society on the grounds of logical congruity or symmetry and order. All phenomena are now judged from this point of view of causation. Beginning with Robert Owen, who held that the facts of the industrial world shape men's thoughts and that these thoughts shape the social structure, the test of quantitative causation has been more and more widely applied, until it has been carried into the spheres of psychology and sociology, and even theology is now approached from the anthropological side. Since men must think in a unity, when the industrial life had forced them to think in a certain way regarding that side of their activities, they were forced to think in the same way regarding the whole universe.

The culmination of the English scientific movement was the doctrine of evolution, which banishes every remnant of animism from all explanations of the world except those of the most remotely metaphysical sort. From another social influence, namely, the feeling after a social solidarity after the Napoleonic wars had caused a break in the social consciousness of Continental peoples, the general organic view of Hegel and the sociological method of Comte were derived. These, worked over from the English scientific point of view, have given direction to all modern thought. Thus, the conception of an orderly evolution proceeding wholly according to natural laws has been applied to the explanation of all phenomena of the world and of society. Thus, the social evolution itself has provided a method for the explanation of itself.

It is in the use of this scientific method that we may expect to arrive at the formulation of the ends which should guide social action. The latest of all the sciences, sociology, nevertheless appears as the most important, because the problem set for its solution is of such tremendous importance; yet the social conscious. ness may arrive at a conception of the true social ends without the assistance of any of the disciplines of the schools. It is not 
yet possible to give definite statement to that ideal which society needs to bring its activity to more orderly progress; but its general outlines begin to appear. There can be little doubt that the end which shall give rational guidance to the social life will be a formulation of the ideal social organism. This will not be a crude biological analogy or picture, though that may have been of some service in the development of sociological thought, but will be a conception of social relations so fundamental that the individual will appear both as a social unit and as a social product. The nature of society should be so clearly stated that the general elements of social welfare shall be as universally recognized as the place of the Church was in an earlier period. It must be recognized that the social ends will be attained through the functional activity of all individuals; and that all of the values of society will be poured into every individual life. This will be the scientific reconstruction of the Christian conception of the value of the individual and of the identity of the interests of the individual and of society. This end, the ideal social organism, having

${ }^{t}$ been formulated as a working-guide, economic activity and political activity would drop into their duly subordinated places. The future would rule the present as completely as the past once did.' Western civilization, having reached its maturity, still shows no signs of decay. Other peoples believed that their past would continue; we believe that we are moving toward a better future. Let this belief in the continuance of evolution broaden into an adequate conception of its ideal outcome, and the special sciences and the arts of social life, reconstructed on the basis of this wider generalization, will guide the details of social activity in such manner that, without introducing a frictionless utopia, the steady progress of the unfolding conscious social life will be assured.

Modern thought must always be characterized by procedure from the particular to the universal. External standards can never again guide social action. Nevertheless, standards are evolved in the process itself; and there is no reason why Science may not be of assistance in the projection of ruling ideals that can guide the whole social life.

$\therefore$ Cf. Kidd, Principles of Western Civilization, 344, 345. 


\section{APPENDIX}

\section{METHOD AND SCOPE OF INQUIRY}

When the student of sociology goes to work in earnest upon any important problem, certain difficulties are brought painfully to his consciousness. Realizing the importance of facts upon which to base valid generalizations, he yet finds it exceedingly difficult to obtain them, even in this scientific age. In the next place, the complexity of the phenomena with which he must deal almost baffles generalization, even when the facts are obtainable. And finally, while there is a manifest interrelation of the groups of facts with which the various social sciences deal, the division of labor among the latter is so incompletely carried out that the person who desires to view the whole field finds many gaps which he must himself fill before he can proceed with his own line of investigation.

THE RELATION OF FACT TO INTERPRETATION

Students are becoming more and more convinced that the first need-facts which may be used as a basis for conclusions-must be met before genuine progress can be made in generalization or in the framing of social programs. But this demand for facts, for a collection of data to be drawn upon when the social philosopher desires to formulate a principle or frame a policy -in short, for a "Descriptive Sociology"-has not been satisfied; and it may be questioned whether it can be satisfied. It is almost inconceivable that facts, as mere facts, ever can be collected in such shape as to be of any particular value for generalization. It is true that the mere collector of information may be useful as a statistical questioner or a copying hack under the direction of the actual investigator; but his usefulness in that capacity consists in faithfully following the clews given to him by his superior-unless, indeed, he discovers a new clew and becomes something more than a mere collector. The starting-point for every investigation must be some sort of an hypothesis; otherwise, it will result in a mere 
unclassified catalogue of as many things in the universe as the investigator may find time to set down. This working hypothesis which determines the field of investigation is itself determined by the attention of the investigator. Its value as a clew, therefore, depends upon the vital relation of the investigator to the real social movements of his time. For if the social life is organic, it will doubtless reveal something of its real meaning in any of its manifestations, and will also recapitulate, though perhaps in shadowy form, many of the essential characteristics of its own past. Hence the poet may receive an inspiration to interpret that life in terms of feeling, and the student may find clews which lead to fruitful results in the attempt to give a systematic statement of the nature of social life.

If it is psychologically true that the investigator's attention determines the field of observation, the facts needed for a given study can be secured by no one but the student himself. If he goes over ground which has already been covered, his duty may be simply the testing and analyzing of facts already secured by others whose general point of view was much the same as his own. If he goes over the ground which investigators in various departments have touched upon, he may gather up facts that had been used for other purposes; but he must here cull them out from others for which he has no use, and usually he must re-examine them. If he goes over ground which has never been covered before, he may be assisted by observers who have no interest in his ultimate purpose; but here he must organize the plan of work himself and use his assistants as little more than unskilled laborers. Where the work to be done by such assistants involves the search for facts amongst which the variable elements are more important than the common, the recorder of the facts is likely to neglect the former and thus make the latter meaningless. Where, as is usually the case, the guiding hypothesis needs to be reconstructed at every step, the assistant who is but a describer will, of course, fail to see the change which the course of the investigation should take and will therefore neglect to report some of the most important facts which have come before him. Only where the simple 
answers to inquiries which have been carefully planned by the statistician who knows what he wants are gathered by the assis. tant, or where the latter has merely to :opy the statements laid before him, can the work of description be carried on profitably independent of the work of generalization.

Works which have been produced by the author's arrangement of materials collected by assistants have usually shown serious defects. ${ }^{x}$ Even the trained investigators in a university seminary, whose general point of view is so nearly that of their instructor, find it almost impossible to operate in genuine collaboration, unless their problem is definitely set for them and the specific facts are simply to be gathered where they are told to look for them.

If the above statements are correct, it follows that there can never be a descriptive sociology apart from some sort of a social philosophy. If one should be built up, it would have to be torn down by the first student who might have occasion to use it, and he would also, doubtless, have to go beyond the débris for much of the material needed. Probably no one has ever made use of Spencer's monumental Descriptive Sociology, except as an illustration of a certain method of classification.

The importance of getting actual facts upon which to base our conclusions is not to be underestimated on account of what has been said above; but the possibility of finding them classified for use, or of finding them in the world and classifying them for our own use, except as we find them in an honest endeavor to test the hypotheses which have come to us in the development of our interest, is distinctly denied. It is important, however, to remember that our guiding hypotheses may be expected to undergo reconstruction at every stage of our investigations; and, therefore, logically, though not chronologically, description must be kept in advance of interpretation. ${ }^{2}$ It is only because of the very ap-

×. g., Bancroft's histories of the peoples of the Pacific slope. Herbert Spencer would probably have drawn fewer conclusions from facts that have a different meaning when viewed in their real setting, had he not depended upon secretaries to gather his data.

2 "Our general rule of sociological method, therefore, can mean no more than 
parent discrepancy between the actually known facts and the demands of our present scientific methods that the want of facts is so keenly appreciated by the investigator. ${ }^{x}$ Little by little, as uniformity of purpose directs the research of sociologists, a mass of materials will be accumulated which will be available for all. At present, fruitful points of view are as necessary as assured facts; and neither can be obtained without the other.

Now the unfortunate thing is not so much that the student of social problems finds a dearth of materials upon which to base conclusions, thereby rendering his progress slow and his generalizations uncertain, but that the tendency is so strong to hold to the original hypothesis and to search only for facts to prove it, neglecting, or remaining blind to, those which either contradict the original theory or render its reconstruction necessary. ${ }^{2}$

The field covered by the preceding study renders the collection of data for generalization a very difficult task, and there is always before us the danger that some important facts have been overlooked or are unobtainable, and that our conclusions are therefore uncertain. But if our working hypothesis is sound and fruitful, and if the statement to be made later on concerning the nature of the evidence required in this kind of an investigation is justified, it may reasonably be expected that the main conclusions reached are valid.

\section{THE COMPLEXITY OF SOCIAL PHENOMENA}

The second difficulty mentioned above-the difficulty of generalization because of the complexity of the phenomena involved - leads to another unfortunate tendency among students of sothis, that on the whole those investigations in which deduction plays the less important part should precede those in which it plays the more important part. This rule will not only keep description and history in advance of explanation, it will also keep description in advance of history - the study of the coexistences in social phenomena in advance of the study of the sequences."-Giddings, The Principles of Sociology, 55 . I, 20I.

× Cf. Small, "Static and Dynamic Sociology," American Journal oj Sociology,

2 A conspicuous example of this is Adams' Law of Civilization and Decay, a most suggestive work, but one that is spoiled by the rigidity of the author's "purpose." 
ciety, namely, the tendency to lose interest in the real meaning of the investigation and to become mere collectors of facts for their own sake. The interest then becomes that of the antiquarian rather than that of the scientist. Oppressed by the magnitude of the task of studying society, it seems that human nature tends to one or the other of two extremes; on the one hand, we find mere theorizers who are satisfied with the faintest shadow of evidence, and on the other, mere observers who are swamped by their facts and do not attempt to come to generalizations. The former remain with the universal, but do not justify it; the latter with the particular, but do not bring out its meaning. The former will manipulate their hypothesis, working it over chiefly by the help of the imagination; the latter will either start with a superficial problem and gather superficial facts to fit it, or lose sight of the real problem with which they started and find their interest in the mere collection of facts which are only superficially related. ${ }^{x}$

Although it may seem, on first thought, that sociology must suffer most from lack of adequate observation, it is probably true that it suffers quite as much from failure to know how to use the facts actually possessed, and that advance in description and in generalization will go on simultaneously. A just conception of the problem which he is working to solve is as important an element in the social thinker's equipment as is his indefatigable zeal in searching for data. The solution of the more specific social problems, then, must depend upon the sifting and analyzing of facts from the point of view of a sound psychology and a sound sociology. We have, of course, no guarantee that we yet possess either of these, but it may reasonably be assumed that certain fundamental conclusions of both of these disciplines will stand. This may seem to prepare the way for a claim that an $a$ priori method is valid. And it does. In so far as our psychology and sociology have been truly worked out, they may be used for the interpretation of tendencies, past, present, and future, and re-

I For a statement of the proper balance between these two extremes, vide Small, "The Sociologists' Point of View," American Journal of Sociology, III, 145-70. 
lieve us from absolute dependence upon the concrete facts, except as the latter are needed to furnish content. But neither of these disciplines can yet claim to be a perfectly developed tool. Perhaps neither ever can be perfected. Certainly, they can never be, except $a s$ the problems are worked out; and then both the content and the form will have been mastered. The claim for them, then, can only be that although they are still in process of development, they may be used to mark out the general lines along which an inquiry must proceed; and that their aberrations may be expected to be corrected in the process itself. In some way or other, our investigation, if it is to have any value, must be guided throughout by such a point of view, and must have as its end conclusions rather than the accumulation of facts.

The dependence of the most painstaking students upon working hypotheses which arise from their general social Weltanschaunng and the correction of their unconscious bias by the development of the social consciousness, is illustrated by the history of a certain line of investigation which has a bearing upon the foregoing study. When the liberal tendencies in political action were in danger of being checked by the Restoration in France and the Reaction in Germany, the liberal movement found relief by turning away from the harsh present to the freedom of primitive institutions, and gave expression to conceptions of the fundamental rights of man, avoiding the excesses of the revolutionary philosophy. The Mark theory was developed under these circumstances, and held sway so long as the agitation for manhood suffrage lasted. But as political aspirations were realized and it was found that democracy was full of imperfections, men became willing to regard their primitive ancestors as very much lower down in the scale of civilization than the free villagers had been supposed to be. ${ }^{x}$ This pressure of the realities of social life into the consciousness of students was reinforced by the scientific doctrine of development, until today only the most biased Germanist holds to the Mark theory as it was stated by Kemble and von Maurer. Now it may be said that the present bias under which students

I Andrews, The Old English Manor, I-5. 
are working must vitiate their results to the same extent to which their predecessors' conclusions were found defective. But we may answer: Whatever the defects of the present standpoint, it can not but be more adequate than any that has preceded it. Not only have we a more highly developed social consciousness growing out of the more complete interdependence of men in society-a condition which has itself grown out of the social situation which conditioned the earlier social consciousness; we have also clearer conceptions of the method of all life as they have been worked out by the biologists and psychologists. Our hope, then, whatever may be our fidelity as observers of facts or our clearness in generalization, must be chiefly in our ability to get "the sociologists' point of view."

\section{THE INTERRELATIONS OF THE VARIOUS SOCIAL SCIENCES}

The third difficulty mentioned above-the failure of the special social scientists completely to cover the ground-is partly explained by the foregoing. The man whose interest is wholly in politics will necessarily observe only those phenomena which are distinctively political, and will study these only in their political aspects. He will select his facts with reference solely to their common political characteristics, neglecting the differentia which in one instance constitute a political fact a fact for economics as well, and in another instance constitute it a fact for ethics as well. It is undoubtedly true that every fact for sociology is likewise a fact for politics and economics and ethics and other less important social sciences. But this does not mean that when the political scientist, the economist, the ethical philosopher, etc., have drawn their conclusions, the sociologist has simply to synthesize their results. Before sociology can become a synthesizing science, it must become a reconstructing science. These differentia, which the special interest in common characteristics almost certainly causes the special social scientist to neglect, are often the most important of all. The common elements, as political, ethical, etc., concrete and definite though they may be, are in reality but abstractions, and are valuable only as indi- 
cating a certain residuum which is found in all situations and which must therefore be taken account of. By themselves, these abstractions can not justify sound conclusions. The most abstract reasoner is one who rests satisfied with the common concrete facts. ${ }^{x}$ The important thing to study is the setting of the facts which thus recur, to discover at what stage of the social development they are found. This is necessary if the organic point of view is taken; but this is just what the student whose interest is narrowed to the special phases of the phenomena is most likely to neglect. It therefore follows that, when the results of all the special social sciences are put together, there will remain numerous gaps which must baffle the person who seeks to get a general view of social phenomena in order to come to conclusions concerning the method of social development. It is not sufficient that the general sociologist should carry on his investigations within the fields of the special social sciences, hunting up facts which have been neglected by the specialists in the respective fields: the very facts which have been considered by the special social sciences must be re-examined from the new and larger point of view. Nor is it sufficient that sociology should synthesize the results of the special social sciences: those sciences themselves must be reconstructed from the point of view of the organic relationships existing among the various phenomena with which they deal. The variable elements which have been neglected in the study of the facts that have been differentiated and catalogued under the special sciences are frequently the very phenomena to be considered when we want to discover where those catalogued facts themselves belong in the organism. The facts have lost much of their value by being detached from the system of which they are a part.

This naive claim of sociology to reconstruct the special social sciences may not be very favorably received; but in order to understand the general relations of the social forces to one another, it is nevertheless necessary to go back of the results of the special social sciences both to deal with the facts upon which the conclu-

× Cf. Muirhead, "Abstract and Practical Ethics," American Journal of Sociology, II, 34I-57. 
sions of the respective social sciences are based, and to rediscover the neglected variable elements which reveal the unity out of which those sciences have been differentiated. The concepts of the special social sciences were, in many cases, developed before the general principles of evolution and the organic nature of society were understood. Those concepts may be very useful, though not entirely adequate, for the purpose of criticizing from the larger point of view the phenomena now distributed among the various social sciences; and, therefore, valuable investigation into the method of social evolution may be possible, though it can not be final, before sociology has been able to reconstruct the special sciences. Indeed, it is by such investigation that the reconstruction will be wrought out.

\section{THE ORGANIC NATURE OF SOCIETY}

The point of view that will be found most fruitful in the examination of diverse social phenomena is that of the organic nature of society. This is also the point of view from which the special disciplines may be reconstructed and unified. The main interest in this study, however, has been with the facts of social life, rather than with theories about those facts. These facts have been regarded as having aspects which differentiate them for the three main special disciplines-ethics, dealing with the ends of social life; economics, dealing with the means; politics, dealing with the structure through which the means are adjusted to the ends. Of course, these sciences as here defined are given a wider significance than the conventional one. For example, "structure" is to be distinguished from the government, or even the state, which represents only one of the social organs. In the preceding pages it will appear that the social structure has always been much wider than any state. The tendency, however, has been for the social organization to express itself in the political organization (in the narrower sense). To that extent the state represents the realization of the social ends up to date. Thus, the feudal organization had to give way to the modern state; and, so socialists claim, the present industrial movement will 
burst the modern state and give birth to a more natural one. Whether this more generic application of the terms "ethics," "economics," "politics" is justified or not, there are such generic aspects of social facts. These must be recognized; and the unification of these special sciences must involve the recognition of the larger relations of the phenomena which each has abstracted. When we regard the telic, the instrumental, and the structural aspects of social phenomena, we are taking the organic point of view, thus unifying the sciences which deal with these respective aspects of social phenomena.

By "organic point of view" no reference is intended to possible analogies between society and any biological organism. Most of the criticisms that are professedly directed against the "organic concept" are in reality criticisms of the "biological analogy." That such analogies may be helpfully used as aids in the classification of social phenomena is not here denied, but they have not been used in this discussion. Society is considered, not as like an organism, but as being an organism. In applying the term to society, the term itself must be reconstructed; just as a concept of organic relations which had been worked out with reference to vegetable life only would have to be reconstructed and made more general when applied to animal life. A generalized conception of "organism" must be reached, which is not limited in its application to phenomena of vegetable life, or of animal life, but which, while helping us to understand these, will also enable us to understand the more complex phenomena of social life. The following is such a generalized definition of an organism: It is a whole whose parts are intrinsically related to it and which gives meaning to the activity of all its parts; whose development is from within and is maintained through the continual interaction of all the parts; and whose end is developed through the activity of the organism itself. In the process of organic development there is a correlative specialization and interdepend-

I If in some cases the end seems to be given from without, it is nevertheless true that it becomes the end of the organism only as it is assimilated through the activity of the organism. E. g., the end of European society, as discussed in the following pages. 
ence of function; and the unity maintained is a unity of function rather than of mere structure. ${ }^{x}$ The objections urged against various biological analogies do not hold against this view of society as an organism.

From this general point of view of the functional relationship of the various facts of social life-facts which from a given point of view may be termed religious, from another economic, from another political, etc. - an attempt has been made to trace the process of development of modern society. The Church was not isolated, to be regarded as an institution acting under a divine command to convert the world or to glorify God; it was regarded as an organ of society, differentiated in the social process itself, and having its activity conditioned by the general social conditions. And so with all other institutions and forces with which we had to deal. In no case was the structure considered for its own sake. It was studied with reference to what it contributes to the on-going social life.

But our point of view must not only be organic: it must also be psychological, or, better, psycho-organic. This does not change the position stated above. Society is none the less organic because the main facts concerning it seem to be psychical. Psychical phenomena present characteristics which are quite as organic as those of biological phenomena. Baldwin's criticism ${ }^{2}$ of the "social organism" has little point against the concept as stated above; and his "psychological organization" is misleading in that it ignores the non-psychical factors in the social life. Nor is it sufficient to set these non-psychical factors off by themselves as "extra-social conditions." ${ }_{3}$ The various selective forces and physical conditions are as much social facts as are the thoughts of individuals. The view which regards the on-going activities of the social life as the essential social fact is much more adequate

Mackenzie, Introduction to Social Philosophy, I64-203, amplified from an unpublished statement by Dewey.

- Baldwin, Social and Ethical Interpretations in Mental Development, 520-23.

3 Baldwin, "The Social and the Extra-Social," American Journal of Sociology, IV, 649-53. 
than one that abstracts the psychical phenomena and regards them as the whole of society. It is true that the most striking facts of society are frequently the thoughts of individuals, because the values of the activities of society are realized in the consciousness of individuals. A genetic study involves an investigation of all social forces; but since the experience of the society is recapitulated in the consciousness of the individual, we find our problem to be in part the statement of the social values as they are realized in the individual. The worth of the individual is found only when we come to an understanding of society. The individual is " $a$ social out-come rather than a social unit." " His relations to society are thoroughly organic. The individual can be defined only in terms of the society of which he is an expression. ${ }^{2}$ Growth in individuality means growth in specialization of function as an organ of society. The social problem is, in large part at least, the organization of the social consciousness on the basis of the activities of individuals as reacted upon by society; and the individual comes to consciousness of his own activity through the interpretation of it in the social interactions which result from it. One of the main interests in any study of social evolution must be in the way the individual grows in value through the functional division of labor.

\section{THE GENETIC STUDY OF SOCIETY}

The importance of a study of the development of the social forces which today demand our attention can hardly be questioned. A genetic explanation of any phenomenon may not, indeed, be a complete explanation of it, but no explanation is adequate which does not include the genetic explanation. Certain kinds of historical studies, whether of fossils or of human societies, may have practically no vital connection with the investigation of present

I Baldwin, Social and Ethical Interpretations, 87.

2 "There are two fundamental inquiries at the bottom of any adequate theory of society. The first is this: How far a complete knowledge of the individual man in society would also be a complete revelation of the society which he is in? And the second question is this (the reverse of the other): How far is it necessary to understand society, as it actually exists, in order to construct an adequate view of the man's actual nature and social possibilities?"-Ibid., 184 . 
life activities, but these do not detract from the value of a genuine study of development.

Because of the relative ease with which facts concerning the present may be gathered, and the great difficulties in the way of securing satisfactory information concerning the past from records written by men whose interests were very different from those of the modern student, there is a strong temptation to follow the line of least resistance and study only contemporary society. This tendency is most marked in the case of men who are drawn into movements which are working for immediate reforms. Yet, since the scientific methods of today are so largely dominated by the theory of evolution, many students of society have felt the necessity of discovering the methods of social development in order to interpret present tendencies. Naturally, perhaps, they have turned to the comparative study of existing societies which are in different stages of development; for not only can these be observed with a considerable degree of certainty, but the facts concerning the very beginnings of social life which may be reasonably inferred are of great value in studying the more complex phenomena of our own highly developed society. It has thus become impossible for a man to do respectable work as a sociologist without having a fair knowledge of anthropology and folk-psychology; and, indeed, the very best work in sociology has been within those fields. The way in which certain social tendencies originate and the way in which certain social institutions develop under varying circumstances can be best discovered by the study of simpler social conditions. There is undoubtedly still a vast mine to be worked in the interests of general sociology.

But when all this has been said in favor of the anthropological method, its limitations must still be recognized. The first of these is found in the fact that existing savage and barbarous societies are not only not the ancestors of existing civilized societies, but are not even in a line of development which can possibly lead to a stage of civilization such as we find in modern Christendom. They are as old as the civilized societies; their structure is in most cases so rigidly fixed that it inconceivable that any change 
in their environment would result in a development into societies such as those which make up the civilized world. The beginnings of the highest Aryan civilization were found in a time when the social structure-and perhaps the individual-was more plastic than that of existing lower societies, and when the environment was different from any which may now have a determining influence upon the lower races. If the Slavs or the Chinese sometime become the highest representatives of civilization, the course of their development will have to go through different stages from those through which the Greeks, Romans, and Teutons have passed. Many elements which are common to all social development are discoverable by the comparative study of the cases of arrested development that are found in contemporary lower societies; but it is only in the simplest stages of culture, when the differentiation along diverging lines has proceeded to but a slight extent, that we may expect to derive much benefit from a comparative study of the existing lower races.

But aside from the difficulty just mentioned, it must be remembered that after all the information that anthropology can give, a tremendous hiatus must remain between the highest point to which any of the so-called lower races have ever attained and that at which we find our own society today. A work is needed to come between, say, middle barbarism and contemporary western civilization. To understand the course of development of modern Christendom - a course which no other society has ever passed over - an historical survey is needed which shall take in, not only the development of Teutonic groups from barbarism to their present civilization, but also the older civilizations which they appropriated. The investigation, then, of modern social institutions involves historical as well as anthropological (in the narrower sense) studies. If we are to study social evolution at all, it will not be possible to satisfy ourselves with an examination of the beginnings and early development of social life and of the highly complex outcome of the present day. The intermediate stages are in some cases the most important of all. There are probably some social tendencies which we may 
intelligently consider without paying much attention to their genesis. These must be such as are simple and transparent in nature and carry on their surface the prophecy of their destiny. But these must be simply superficial forces. The important institutions of society have a long life-history. They are the outcome of past movements and are moving toward a future which their past largely determines. No difficulty in the way of gathering data, no pressure for quick results, should deter the student of society from seeking a genetic explanation of the phenomena

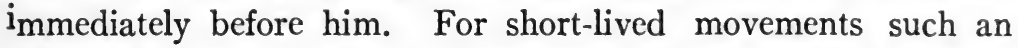
explanation may be found by examining data which the records of the present generation supply; and when the changes in social life are very rapid and very radical, contemporary facts may be most important in explaining institutions which seem to have their roots in the remote past. There is no essential distinction between past and contemporary history. The important point is that the course of development must be traced, be that course long or short. Nevertheless, it may be questioned whether the really important institutions and significant forces are ever those which have had a short course of development. A revolution may occur and a convention may draw up a new constitution, but we know that such constitutions are purely artificial. The event is significant, as showing the outcome of a long course of development and a change in the habits of the people, but the constitution itself is of trifling importance. If it is to have any importance in the after-life of the people, it must be merely the crystallization of tendencies which have long been present. In so far as it is not the expression of the real genius of the people, a few years will see it rescinded or modified. ${ }^{x}$

A mere sectional view of society is not of very great value. "If sectional views are taken at many different periods, especially at critical periods, the movement from one status to another may

x "In all its phases society is under limitations imposed by its history. Every social condition is the outcome of previous conditions and events, and each such condition consists of a multitude of influences from which subsequent developments proceed. Accordingly there is no difference in principle between social and historical laws."-Wundt, Logik (2d ed.), II (Methodenlehre), sec. ii, 437. 
be readily inferred; but the study then becomes dynamical rather than statical. Probably, however, the best results can be secured by considering the movement itself in connection with the statical phenomena. Wherever the emphasis is laid, the movement, the line of development, is always of more importance than the attained values at any point. ${ }^{x}$ The latter may have an æsthetic interest; but the life-movement of society alone can be of importance for social philosophy. Social evolution is analogous to all other kinds of evolution; it is always gradual. By degrees structures are modified, and in the course of ages customs, laws, and institutions undergo radical changes. ${ }^{2}$ While the structure remains unchanged the social life may be so changing that the structure becomes meaningless. It represents simply a survival, and, except for æsthetic purposes, ${ }^{3}$ must soon undergo modification or be entirely done away. The real social life, the movement, is of importance for sociology; a statical view of society is of importance only as contributing to a dynamical view.

The distinction which Ward draws between statical and dynamical facts is not, in the last analysis, of importance, if, indeed, it is justified at all. He would regard any movement which does not change the type as statical. Both structure and function would have to be regarded as statical, since he holds that a change of type is brought about, not through the functioning of the organism, but through some force with which feeling is connected. Any quantitative change is static, while a qualitative change is dynamic. 4 Now, the change from one social type to another is undoubtedly of capital importance; but is not this the ultimate

I "It has therefore been the movement rather than the status of society, which it has been sought to explain; the causes of social phenomena and social progress rather than the condition of society itself. The status, or condition, of society is to be learned by the consideration of the indirect, or functional, effects of what have been denominated social forces."-Ward, Dynamic Sociology, I, 70r.

2 Ward, "Social Genesis," American Journal of Sociology, II, 537.

3 By æsthetic interest I mean an interest in attained values for their own sake. An æsthetic value is an attained value which is appreciated immediately, and not because of its place in any future development.

4 Ward, "Static and Dynamic Sociology," Political Science Quarterly, X, 207-r8. 
result of all functioning of the type which becomes changed? The purpose of all functioning is to maintain the life-activity of the organism which is primarily bound up with the existing structure. That is, the purpose of function is to maintain the type in statu quo. But if the environment renders it difficult for the existing structure to function, the functioning itself will lead to a modification of the structure. This would be true even from the point of view of extreme Weismannism. The same force, which under established conditions simply maintains the existing structure will, when the structure is no longer adapted to its environment, lead to a change of type, function and structure correlatively undergoing change in order to meet the new situation. The feeling upon which Ward lays such stress arises when there is a check in the on-going habits. If that check is but temporary, no change in the type is noticeable; but if it is permanent or radical, the organism must undergo modification or perish. ${ }^{\mathrm{x}}$ There is, then, no purely quantitative change in organic life, for the same general life-activity, which before the change of type is called function by Ward, is the force which brings about the change. It may seem desirable to call the functioning statical when the organism and its environment are in equilibrium, but this is simply equivalent to saying that the structure is undergoing no change.

The position above taken emphasizes the importance of a consideration of activity as the key to social evolution. If a statical view of society is taken, it will be possible to attend simply to the various types as they successively appear. But it must be remembered that these structures which are adapted to a cer-

× On Ward's claim that everything connected with feeling is dynamic, Small says: "Then everything social is primarily dynamic, since it has its roots at last, in the feelings of the social units. My weariness when I go to bed at night (feeling), and my hunger when I rise in the morning (feeling), are more intimately connected with the static functions of restoring the bodily tissues than they can possibly be with any dynamic function, say of instigating a revolution in the interest of easier food supply for my descendants. .... Whatever be the categories according to which we divide social phenomena, feeling of some sort will have to be recognized in each and all of them." "Static and Dynamic Sociology," American Journal of Sociology, I, 198, note. 
tain kind of functioning must be constantly changing by slow degrees, if the environment changes, or must perish. It is not their status in which we are interested, but their method of development; for the status can not be maintained. The functioning gives the clew to the mode of social activity which, after all, is the only real thing.

Our purpose, therefore, is to study the functioning of society, in order to understand, not only its self-maintenance, but also its method of development. Of course, the function can never be studied except in connection with the structure through which the functioning takes place; but the emphasis here must be upon function rather than structure. In the examination of an animal or vegetable organism whose structure is practically fixed, the structure may be taken as a sufficient index to the constant mode of functioning. To know the structure would then mean to know the function, not only for the time, but for practically all time. In the examination of a fixed, or relatively fixed, social organism, as some Asiatic communities before they have been disturbed by civilized nations, the structure may be regarded as permanent and therefore a sufficient clew to an understanding of the function. I In so far as the structure is rigid and is yet so well adapted to the environment that it is able to persist, an understanding of it involves an understanding of the function. But if the organism is relatively unstable, if it is constantly undergoing modification in its double reaction with its environment, the function is always tending to go beyond the existing structure, requiring the latter to readjust itself to meet the new situation. In such cases the study of the function will prove more fruitful. In both cases the life process consists in the functioning of the organism through its structure; but in the latter case the relative importance of function is greater than in the former. The function will represent a continuous process which not only coincides with the well-adapted structure, but which may also burst through the structure when the latter no longer corresponds to the demands of the environ-

I Barth, Die Philosophie der Geschichte als Sociologie, Ir. 
ment, and which carries on the organism to the formation of a new type which shall be adapted to, or in, the environment.

The conditions just described are found in no other organism so fully as in modern society. The society which is the object of this investigation is today, and has been throughout the period which we shall study, extremely mobile. From the period at which we first discover it up to the present time, it has never been stationary. It has not been in a state of flux. If it had been, it must have perished before this. Its structure has usually been well defined, and has resisted change until the change has become inevitable. But, at the same time, it has been constantly developing-not merely constantly growing from the cumulative effects of "statical" functioning, but evolving new types through the modification of its structure to suit new conditions. The dynamics of such a society must be much more important than its statics. The student of such a society must be a physiologist rather than an anatomist. As has been said above, the statical view of society will be helpful only if many cross-sections are taken, and then only in order that the movement from one stage to another may be observed more clearly. The status of such a society can not be maintained, and is not worth studying for its own sake: the movement is everything, and must be mastered. Therefore, the study of existing institutions, since they are tending toward new types, must be indissolubly connected with the study of social history.

Barth's criticism of Wundt's attempt to separate sociology from philosophy of history bears directly upon this point. Wundt would give to sociology the status (Zustand) of human society, and to philosophy of history the process (Vorgang) which gives rise to the status or condition. ${ }^{x}$ Barth justly holds that this' distinction is not valid, because society never stands still but is always in process of development. To state the principles of a stationary society, as Wundt would have sociology do, is perfectly possible, since it would be but to abstract the universal from the

× Logik, II (Methodenlehre), sec. ii, 438. 
particulars. But this is impossible in the case of a developing society. There, to include the conditions causally and so to explain them is only possible when we trace their becoming. ${ }^{x}$ History alone can complete Wundt's sociology by raising it from description to explanation. Small makes a similar criticism of Wundt. He holds that there is no difference in kind between a law which is to be called social and one which is to be called historical. This is especially true concerning a law of succession rather than one of correlation. It is neither necessary nor desirable in the interest of sociology to claim that such difference exists. Rather is it in the interest of truth and clearness to admit that sociology is concerned primarily, so far as it deals with historical material, with generalizing into universal formulas the facts of serial and causal relationships which the historians make out in particular cases. What the philosophers of history tried to do is genuine sociological work. ${ }^{2}$

\section{THE DEMANDS OF SOCIOLOGY UPON HISTORY}

When we come to gather the materials which shall serve as the basis for a genetic explanation of social phenomena, we find that the ordinary histories do not give us the assistance needed. The first impulse of the sociologist who needs historical data is, of course, to turn to the professed historian for the information he craves; and, more particularly, when the matter is of a constitutional or legal character to the historian of law. But when he does so, he is only likely to find one of two things. Either the information he receives, while it has a grammatical consistency, yet leaves him quite in the dark as to the daily life of the people concerned-he asks for a picture and receives a formula; or, instead of one answer to his inquiry, he is given several, all from eminent authorities, and absolutely irreconcilable. Then, probably, he gives up the quest, and falls back on some neat little $a$ priori theory of his own as to what the course of economic evolution must have been. If he does not, but makes up his mind to go to the original sources for himself, he will be fortunate if he escapes an occasional sly thrust from historian and lawyer for venturing beyond his last.

I Barth, op. cit., rI, I2. "Aber die Zustände kausal zu begreifen und so erst völlig zu erklären, ist nur möglich, wenn man ihr Werden verfolgt" (p. II).

2 Unpublished criticism on Wundt, loc. cit.

3 Ashley, "The Beginning of Town Life in the Middle Ages," Quarterly Journal of Economics, X, 359, 360. 
The history is usually either a mere description of curious customs given as - for the time being-statical, or a treatment of the development of political institutions abstracted from the general social movement. Both kinds of history may contain much valuable material which may be worked over by one who desires to get a general view of the social development, but are quite likely to leave gaps at important points, if, indeed, they do not give false interpretations. The former, at its best, is a chronicle; the latter is an interpretative undertaking, but deals with an abstraction, and so must be reconstructed in some degree before it can serve the purpose desired.

Since the time of Niebuhr, the method of history has made wonderful strides. The critical scientific method has cleared the ground of much rubbish; and there is no doubt that the judgment of the historians as to the credibility of the evidence with which they deal is, in the main, thoroughly reliable. But this does not change the fact that the best histories are mere histories of political institutions abstracted from the other phenomena of social life. History, instead of being a social science co-ordinate with economics, politics, etc., is a method employed in connection with the discipline of political science. It endeavors to furnish to the student of politics the genetic explanation of political phenomena. This is a perfectly legitimate office, and neither the economist nor the general sociologist has any right to complain because a wider field is not covered, provided the historian does not claim to do all that needs to be done. As the student of politics thus has traced for him the development of political institutions, so the student of ethics must secure a statement of the facts of the development of the moral life, the student of economics needs his economic history, and the general sociologist, using the material thus gathered from these special points of view, must have also at his disposal an account of the development of the social life in general. Correlative with these histories, and depending upon them to some extent, there must be a history of politics, a history of economics, a history of ethics, and a history of sociology. Or, perhaps still better, there might 
be a scientific treatment of both the data and the philosophies of these sciences, which will give an adequate account on both the historical and contemporary sides of all social phenomena that have a life-history. From this point of view, there is as much reason for an economic history as a separate discipline as for the political history which goes by the broad name of history. ${ }^{x}$

If history proper is the description and explanation of the political development only, it cannot be expected to give the direct information we need, though the indirect assistance both from data gathered and from criticism of sources may be very great. The government, which is the object of greatest interest to political history, is but a surface phenomenon. The important function of government-in so far as it has not been a mere surface indication of social movements-has been protective or conservative of that which has been secured by society through its whole activity, ${ }^{2}$ and thus it has been at once a stepping-stone for further progress and a check upon advancing tendencies. It has never been a positive promoter of the social evolution, but it "has certainly been a sine qua non of it." 3 The classical statement made by Spencer of the character of the historical information needed by the societary student may exaggerate the importance of a certain class of details, but his main contention for all "facts which help us to understand how a nation has grown and organized itself," 4 must express the sentiments of every one who wants to understand the life of society. A later writer has well stated the relatively greater importance of the non-government history:

The history of man, if it should ever be written, would be an account of what man has done. The numerous changes that have been made in the posi-

x Historical writers have treated of many important facts which can not be called political; but it is nevertheless true that their main interest has usually been in the political development, other matters being brought in simply as sidelights. This is true even of the so-called social historians, such as Green and McMaster.

2 Ward, Dynamic Sociology, II, 243.

3 Ibid.

4 Preface to the American edition of The Study of Society. 
tion of certain imaginary lines on the earth's surface, called political boundaries, and the events that have given rise to such changes, would be recorded, but instead of making the bulk of human annals as they now do, they would occupy a very subordinate place. Such changes and their conditioning events are temporary, superficial, and unimportant. They leave no lasting impress and are soon swept by time completely from the real record of man's achievements. The major part of a true history of man would be devoted to the reproduction of this real record. ${ }^{x}$

The point of all this is not that the ordinary historians are to be blamed for not writing the kind of history we desire. They are perfectly justified in the selection of a special field. The results of their labors are subject to no other criticism than that which has been passed above concerning the defects of studies which abstract certain phenomena and fail to modify their conclusions by placing their facts in relation with all other facts. The defect in history, however, is probably slighter than in most of the other disciplines. The only object of these statements is to show that someone must work out a general social history, if the development of society is to be understood. A brief attempt to do this is made in the following pages.

\section{THE METHOD AND MATERIAL OF SOCIAL HISTORY}

When we turn away from the completed political histories, the task of securing a history of social development seems, at first, too great to be undertaken. Not only is historical research as such likely to be somewhat less inspiring to one whose main interest is in contemporary social life, than it is to the historian proper; but the apparent paucity of materials tends to turn one back to contemporary phenomena as the only field that is worth working. The first objection is soon swept away, if the student actually discovers the method of social life; for the method of social evolution is of infinitely greater interest than any amount of concrete information about present-day matters. The second objection disappears when the student finds that many luminous facts are discoverable. Pioneers in economic and social history, such as Cunningham, Rogers, Ashley, and others, have discovered

× Ward, The Psychic Factors of Civilization, 97. 
many rich mines in the museums and libraries, which have already yielded returns that justify the working. The court rolls, monastic records, old chronicles, gild charters, etc., have been preserved in vast quantities. Many of these have been edited and published in monumental collections; many others are still awaiting exhuming. These old documents, often intended to record simple agricultural and building operations, are remarkably illustrative of the inner life of the different communities during that transition period in the development of society in which we are so deeply interested. ${ }^{x}$ The modern student, especially if he is armed with the scientific methods of the time, need have no fear lest time will be wasted in his efforts to trace the course of development of society. With results before us such as have been produced by such scholars as those named above and by such others as Seebohm, Schmoller, Vinogradoff, Fustel de Coulanges, it can no longer be said that the results of historical investigation are not comparable with those which are concerned with contemporary movements. Since important materials are available, no apparent difficulty should deter sociologists from setting in order the data needed for social philosophy. The present investigation has taken into consideration but a minute fraction of the records of the period covered, and that mostly at second hand; but the results, schematic though they are, may be considered about as complete for the Middle Ages as they can be made for the nineteenth century. The purpose here is to put together and interpret some of the results of the eminent investigators who have done first-hand work in small sections of the field covered.

But in order to draw safe conclusions concerning social life, it is not necessary to have mountains of evidence to substantiate multitudinous minute details. There are many facts concerning both the past and the present which may well be neglected. The details of the life of societies are not worth considering except as they illustrate some permanent principle with which we must take account. ${ }^{2}$ It is true that many important facts may be neg-

I Rogers, The Economic Interpretation of History, 3-6.

2 "No history is worth preserving which does not at once illustrate the prog- 
lected in a hasty attempt to select striking phenomena for generalization, and, on the other hand, many details which have been set down by a mere chronicler who had in mind only the accurate recital of everything that had come to his notice may be found to be a perfect mine of valuable information to the investigator who comes after him. Enough has been said to indicate the importance of having sufficient details to furnish the setting of the particular facts from which we are drawing conclusions. The abstraction of the purely political phenomena was shown to be a method which leads to defective results. Evidently, then, many details are necessary to serve as correctives in judgment concerning main facts, and many hitherto neglected facts are needed by those who are seeking to discover the more general principles of life. But with this recognition of the importance of ample data for generalization, the position is still taken that only those facts which indicate permanent principles are of importance for the interpretation of social life. Others can be of only minor interest, and can satisfy only a mere curiosity.

A work of descriptive sociology must be more than a mere record of the redistribution of matter and motion. It must be carried on with reference to present social consciousness. An explanation of development is an explanation of the development of the social consciousness up to the present point. A statical description of existing institutions is a description with reference to the values they are contributing to social life. They are of interest only as they contribute to, or detract from, the values of life; and the test must always be what they give to consciousness. Some present forces which we do not now appreciate may be contributing to a future social value-therefore, we may greatly assist future generations in the effort to understand the meaning of their life by filling our statistical reports and chronicles with all manner of detailed information-but it is only a matter of chance whether anything that is not of value to us will be turned ress of the race, or a permanent influence. . . . . History which does not attempt to distinguish the relative importance of facts, and does not inquire how any contemporaneous set of facts can be pressed into the interpretation, is a mere disordered and imperfect dictionary."-Rogers, op. cit., I, 2. 
over to them. Only incidentally is this ever done. Our historical work must be done with reference to the translation which facts get in the social consciousness. Therefore, many very curious facts may be cast aside as mere trash, and the lack of others which are not now obtainable need not always cause us regret.

The concern of the scientific historian is with the mode or order in which a change in social institutions occurs; but the real fact is that this indicates a change, a development, in consciousness itself. It throws light upon the way in which human consciousness differentiates and enriches itself. Any history which does not tend in this direction is ultimately valueless. Immediately, our fact may be an abstraction, as the fixing of the date of an event; but the date is of value only as it contributes to knowledge of the development of consciousness. If the changes of consciousness are omitted, the history is of no more value than a description of the order in which cobble stones are laid on the streets. Except for throwing light on this development, or contributing to it, the child might as well study the history of an Australian tribe as the life of a few thousand men in Athens. ${ }^{x}$

If, then, the data needed are such as show the development of our social consciousness, the scope of our inquiry is somewhat narrowed and our problem, in some respects, simplified. We need not search for mere multitudinousness of facts. If there is a real continuity in the development of the social consciousness, we may assume that the phenomena which have represented the main lines of development have been translated into the consciousness of men at all periods-though they may not have appeared impressive to the political classes-and thus have been preserved in some monumental form. The myths and legends, poetry and the pictures left in words, have sometimes preserved important information which the court recorder did not think worth writing down. That which represents merely the individual consciousness appears in the worthless details whose lack of continuity betrays their own worthlessness. Only those facts which the social consciousness has taken up and held need be long considered; and all of the data which are considered must be selected with reference to the outcome-the developed social consciousness. This amounts to a restatement of a position taken earlier in this

I Dewey, unpublished lecture on Political Ethics. 
chapter, namely, that our hypothesis-which means our present social psychology-must select the data with which it shall confirm, or destroy, or reconstruct, or enlarge, itself. The data may not be gathered apart from the interpretation; a history of the development of the data may not be constructed apart from the history of the development of the social consciousness; a social history and a history of thought must go hand in hand.

The mistake is sometimes made of considering historical materials as simply serving to confirm opinions about the present. A conclusion is reached about some contemporary phenomenon irrespective of its place in the developing social system, and then it is thought that the only use to be made of historical materials is to consider them as merely additional data of the same sort as that which had previously been examined and settled. That is, the course of development is entirely neglected, the genetic explanation is not thought worth while, and the facts from the past are simply brought up to the present and used to expand presentday facts. This is the fault of the otherwise excellent work of Keynes. ${ }^{x}$ In his discussion of the place of economic history this writer seems entirely to miss the point. He would use historical facts simply as illustrations of economic theories; not as the means of understanding the development of economic phenomena. He says:

The more specific functions of economic history in connection with the theoretical problems of political economy may be roughly classified as follows: first, to illustrate and test conclusions not themselves resting on historical evidence; secondly, to teach the limits of the actual applicability of economic doctrines; thirdly, to afford a basis for the direct attainment of economic truths of a theoretical character. It is to the last-named function that reference is more particularly made when the application of the historical method to political economy is spoken of. ${ }^{2}$

For example, he finds the historical facts concerning the wages of laborers after the Black Death of particular value as showing the effect on wages of a sudden diminution of the number of laborers; ${ }^{3}$ but he does not seem to recognize the importance of

$x$ The Scope and Method of Political Economy.
I Ibid., 254 .
3 Ibid., $257,258$. 
finding out the method of development of an industrial institution or the meaning of the condition of the industrial population. This method of viewing historical facts naturally leads to the historical fallacy which reads back into the past our present conditions, and also to the total failure to understand the mode of social development.

Keynes is entirely correct, however, when he claims that the establishment of general laws by economic theory is of more importance than the statement of particular concrete facts by economic history. ${ }^{x}$ Mackenzie $^{2}$ has stated the same truth in even more forcible language. The latter holds that the proper function of any science is not merely to explain the development of phenomena up to date, but also to indicate the tendencies for the future.

The economist desires not only to be a historian, but to be a prophet; and the mere teaching of history by itself can never furnish a basis for prophecy. ${ }^{3}$ History can not even tell us that the past must have been as it was; much less can it enable us to predict that, amid the ever-changing stream of conditions, the future will in any particular respects resemble what the past has been. Economics without history-if we may be allowed to adapt the familiar phrase of Kant-would be empty; but without analysis it would be blind. If it is to supply us with any practical insight, it must not only fill in for us the conditions which have determined the events of the past and present, but must help us to calculate to what extent each particular element in those conditions may be expected to have weight in the future. 4

A few pages earlier Mackenzie makes a more general statement of the same truth that he here emphasizes with reference to economics. He divides the work of description into two procedures, the statement of the constitution and the statement of the development of phenomena, and continues:

Wherein does the essential difference between the constitution and the development of a thing consist? So far as the tracing of its development is merely the sketch of the series of its successive states, while the analysis of

IOp. cit., $252 \mathrm{ff}$.

2 Introduction to Social Philosophy, 31, 32.

3 This depends on the definition of "mere teaching of history." History, as defined above, is scarcely open to the criticism here made.

4 Loc. cit. 
its constitution is simply the unfolding of its present condition, there is no fundamental difference between these two things. The one exhibits the nature of the object at a particular moment: the other exhibits the same nature as it presents itself through a series of successive moments. Between these there is no difference but that of time; and there is no particular dignity about a series in time, any more than about a series in space, which should cause the observation of the former to give rise to a higher kind of science. The real difference is to be found in this, that in the case of an historical study we are led to investigate the laws of change as well as the mere disposition of facts or elements. The observation of the oak as it stands is the same in kind as the tracing of its growth from the acorn to the completed tree: a higher kind of knowledge is implied only when we are able to "look into the seeds of time, and say which grain will grow and which will not," or when we are able to explain why from a given grain the growth took place in one particular direction rather than in another. It is, in short, not an historical but a prophetic science which is higher than an observational one.

The object of all science thould be more or less prophetic, and this is particularly true of any science which treats a body of phenomena in which we are so vitally interested as in that which we find in modern society. Nevertheless, a fact which Mackenzie mentions in the passage just quoted has greater importance than he seems to attach to it. If in any study we are "led to investigate the laws of change as well as the mere disposition of facts or elements," we have engaged in a method of investigation which will give us an insight into the laws of future change. Dynamical sociology must certainly be prophetic, but in a very real sense the inspiration of that prophecy must come from the past and present mode of development of society. The best way to get both the analysis and the prophecy is by finding how society came to be what it is. Again, while recognizing the supreme importance of knowledge of the way in which the social organism is to function, we must reiterate the assertion made above, namely, that the genetic explanation must lie at the basis of all adequate analysis of present structure and probable function.

\section{THE RELATION OF HISTORY OF THOUGHT TO SOCIAL HISTORY}

We come now to the consideration of the bearing of such a study as is here attempted upon the study of the development of Op. cit., 24 . 
thought. The histories of thought-histories of philosophy, ethics, political economy, Christian doctrine, etc.-have been carried forward as if they dealt with bodies of phenomena which have a real existence apart from the social activity. In a certain sense it has been possible to regard men's philosophies as completely abstracted from their life. After men have formed a theory to account for the actual phenomena about them, this theory itself becomes a phenomenon to be speculated about in common with all others. Therefore, after certain concepts are worked out, they may have a sort of development apart from the devlopment which is going on in the phenomena of which these concepts were once the explanation. The manipulation of such concepts has constituted no small part of men's philosophies, and their expansion and transformation have constituted the major part of the actual history of philosophy. This aspect of philosophy accounts for the fact that the concepts, which at first had a simple meaning, become, as they are manipulated by later philosophers, abstruse, unintelligible to the uninitiated, and apparently wholly disconnected from the realities of life. But in spite of these tendencies-which, as we have said above, grow out of the fact that thought may itself become an object of thought-philosophy has never, even in its abstractest mediæval form, been able to free itself from dependence on the actual life of society. There is a continuity of thought, making possible histories of philosophy which are more than heterogeneous collections of curious puzzles, because there is a continuity of social life. ${ }^{\mathrm{x}}$

Since the time of Kant, the dependence of philosophy upon the individual sciences, its place as a scientia scientiarum, has been pretty generally recognized; but with the exception of Windelband, and in a less degree Kuno Fischer, no important historian of philosophy has recognized the determining influence of the social life on philosophy. Several have shown some appreciation of the reaction of philosophy on the social life. Windelband has

I "For philosophy receives both its problems and the materials for their solution from the general consciousness of the time, and from the needs of society." -Windelband, History of Philosophy, r3. 
not worked out the statement of this dependence of philosophy, but he distinctly states his conviction that there is such a dependence:

It is evident farther, that the relations of philosophy to the other activities of civilization are no less close than its relation to the individual sciences. For the conceptions arising from the religious and ethical and artistic life, from the life of the state and society, force their way everywhere, side by side with the results won from scientific investigation, into the idea of the universe which the philosophy of metaphysical tendencies aims to frame. ${ }^{\mathrm{s}}$

Further on, speaking of the unity of connection in philosophical systems, in spite of the variety in subject-matter and purpose, he continues:

This common product, which constitutes the meaning of the history of philosophy, rests on just the changing relations which the work of the philosophers has sustained in the course of history, not only to the maturest results of science in general and of the special sciences in particular, but also to the other activities of European civilization ..... In some direction and in some fashion every philosophy has striven to reach, over a more or less extensive field, a formulation in conception of the material immediately given in the world and in life; and so, as these efforts have passed into history, the constitution of the mental and spiritual life has been step by step disclosed. The History of philosophy is the process in which European humanity has embodied in scientific conceptions its views of the world and its judgments of life.

This position will be substantiated, at least in part, in the following pages. It will appear-though this is but incidental to the general inquiry - that the basis of all important philosophical speculations is found in the social life of the times in which they were formulated. Making due allowance for the continuous manipulation of concepts which have become abstracted from the real life of which they were once the expression, it may still be held that the controlling force in men's philosophies has been the introjection of the reality of the cosmos into their consciousness. The development of psychology is an illustration of this. The psychology of the Socratic philosophers was the reflex of the social life of the time. Socrates found the common facts of the artisan life the most important data for his conclusions; Plato

I Ibid., 6. The italics are his own.

I Ibid., 9. 
held that society was man "writ large" and could be read more easily than the small copy, but that the latter could be understood when the former was. Plato scarcely got to an individual psychology, but he laid the foundation for it in his division of the human faculties according to the division of society into classes. From that time, psychology has had concepts of its own to work over; but no psychology has been built up by the mere workingover of these concepts. The psychology of the Middle Ages, the psychology of Hobbes, the psychology of Locke, the modern psychology which in some respects pursues the methods of the natural sciences, all have resulted from the modification of previous psychological notions by the forces of the social life. So, also, philosophy in general has had a course of development from the earliest theories of nature formulated in the Greek colonies, and of society formulated in Athens, but at every stage this development has been shaped by the nature and the society which have pressed themselves into men's consciousness. Historians of philosophy and of theology have been able to treat the great lines of thought as though they ran their course in the air, because their form has been largely foreign to the common affairs of life; but a more adequate treatment would recognize lines of influence rising from the realities of the social life and blending with the lines of thought which have come down from the past. So we have found the theories of Jerome and Augustine, of Anselm and Roscellin, of Descartes and Hobbes, of Voltaire and Rousseau, of Hegel and Comte, to be not merely the vagaries of dreamers or geniuses, not merely theories about theories about facts, but the expression of the actual life of their times. Thought is as organically related to the whole as a factory or a legislature is, and can no more be adequately treated as an abstraction than such institutions can be so treated.

It follows, then, that the prerequisite to a complete understanding of the development of thought is a knowledge of the actual social development, including the scientific views of nature that have been held at the various periods. On the other hand, of course, a knowledge of the social development depends in part upon 
an understanding of the changes which have gone on in the consciousness of men; for as every change in society must change the intellectual constitution of the individuals who compose it, so every such modification of consciousness becomes a new factor in social development and must express itself in a modification of society. ${ }^{\mathrm{s}}$ Of course, this refers only to the thought-movements that are more than mere individual variations which soon pass out of sight.

If this is true of all philosophical systems, it is certainly peculiarly true of social philosophy. Social philosophies are conscious reflections upon the social order, while general philosophies may be only unconsciously, though none the less truly, related to the social order. Since the days of Plato, men have been framing social philosophies. These are important to us, not only because there has probably been a continuity in the thought itself, but because the philosophies help us to an understanding of the social development, which is necessary in order to prepare the way for constructive social theorizing. A history of sociology has not yet been undertaken, except in the rather schematic histories of the philosophy of history. Sociologists seldom go back of Comte; and the development of thought since his writings can scarcely be said to have received systematic and thoroughgoing treatment. Yet the systematization of social thinking, the saving it from its present position of dependence upon the vagaries of individual thinkers, would be largely advanced by the possession of a solid body of information about the past attempts to interpret society.

The work attempted in this investigation, although reference is frequently made to important thinkers, is merely preliminary to a history of social philosophy. Social philosophy, to be understood, must be related at all important points to the society which it attempts to explain. Preliminary work, such as this, may assist in that relation; and, on the other hand, social theories throw light upon the course of the development of the organic social life. Both procedures naturally flow into a constructive philosophy of the present growing social order. ${ }^{2}$

s Barth, Die Philosophie der Geschichle als Sociologie, Ir.

2 Ibid., 9. 


\section{INDEX}




$$
\text { . }
$$




\section{INDEX}

Agriculture: early German, 85; later German, 117-19; later Roman, 11016; Celtic in England, 129, I30; open-field, 129, 130; surplus of, and manufactures, 195 .

Amalfi, $239 \mathrm{ff}$.

Amos, 12.

Ancient period, end of, 68 .

Anselm, 99, 100.

Anthropology and sociology, 377, 378 .

Apologists, work of, 73 .

Aquinas, 100, 101, 289-95.

Aristocracy and religious conceptions, 8, 9.

Aristotle, 49, 50.

Art consciousness and Greek ethical philosophy, 48.

Asceticism, meaning of, 74,76 .

Athenian industries, $37 \mathrm{ff}$.

Atonement, doctrine of, 99 .

Attention, 366.

Augustine, 79-81.

Austrian economists, $35 \mathrm{I}$.

Barbarians: attitude of, toward civilization, 82, 83, 88; Roman influence on, 86,87 , I 5 ; do not introduce individualism, 82, 83; Bryce on, 87.

Barth on statics and dynamics, 383 , 384 .

Bishops and Frankish administration, I55, 157.

Blood-revenge modified, 8.

Britain: agriculture in pre-Roman, 129 ; Roman occupation and three-field system, 130 .

British peasants under Saxons, I33.

Brotherly relation realized in emotional terms, 74,78 .

Capital: in Middle Ages, I9I, 293, 294; and Industrial Revolution, 33I, $33^{2}$.

Capitalism, 33I ff.

Charlemagne: compared with Otho,
95; Sismondi on, 95-97; Bryce on, 96, 97; meaning of his empire, 96; failure of Italian system, 127.

Chief, barbarian, transformation of, I36.

Christianity: eastern and western compared, 78, 79; and Greek thought, 51, 66; extension of, to gentiles, 70 .

Church: development of, 74-77,79; a reorganizing power, 79; magical power of, 89, 297; carries over ideals, 92; authority, 93; economic activity, 94; a universal, 98,99 ; and the serf, 183,$184 ;$ and commerce, 192, 193; economic theories of, 191, 288, 29 Iff.; influence of, for peace, 305, 306 .

Cities: southern French 237-39; Italian, 239 ff.; episcopal, 193, 197, 198; rise of, $201 \mathrm{ff}$.

City of God, 80, 81.

Class-consciousness, $34 \mathrm{I}$.

Collective bargaining, 335, $34 \mathrm{I}$.

Collectivism: and individuality, 319, 320 ; practical, without conscious acceptance, $338,339$.

Colonial system, Roman, 57,58 .

Colonists, American, individuality of, 3 II.

Colons: Roman, I13-15; status of, under Franks, I6r.

Commerce: after fall of Rome, 109 , 186, 187; under Merovings, 164, 187; after Charlemagne, I 64, I 84,189 , I90; and money, 147; histories of, 194; in luxuries, 188; meaning of, 194; character of European, 200; character of Italian, 248; and selfgovernment, 201; and serfdom, 219.

Commercial leagues, $257 \mathrm{ff}$.

Competition, self-destructive, 333 .

Constitutions, urban, 207 ff.

Consumption: Egyptian, 32; Athenian, $4 \mathrm{I}$; and condition of laborers, 4 I, 42, 354, 355; socialized, 338, 353; and production, $350,35^{2}$. 
Contract theory: of Hobbes, 301, 302, 304; of Rousseau, 315, 316.

Control of technique and product: Egyptian, 28, 3I, 32; Greek, 33, 4043; mediæval, I04, II9; by gilds, 23I; by modern laborers, 354,355 .

Cotton industry, English, 328, 329.

Courts, manorial, I52, I53, 168.

Craft gilds: and merchant associations, 221, 227; origin of, 228, 230; Brentano on, 226, 227; policy of, 23I-33.

Dante on state and church, 290.

Demagogues, Athenian, 39.

Democracy, absolutism of, 3 I4 .

Democratic consumption, 356 .

Democratic movement, 309 ff.

Denmark and the Hansa, 267, 268.

Descartes on method, 300 .

Descriptive sociology, 365, 367 .

Deuteronomic code, I 2, I3.

Dewey: on historical method, 390 ; on social organism, 374,375 .

Distribution: overemphasis on, $35^{\mathrm{I}}$; automatic, $35^{2}$.

Domainial administration: Roman, I 10; royal, I59, I79; ecclesiastical, r76-79.

Dynamics vs. statics, $379-83$.

Economic: problem of Middle Ages, 94, 95; independence of manor, 163 , I64; forces and origin of towns, 207; community formed by commerce, 262 ; interests of Hansa, 273; interdependence and end of Middle Ages, 286; interests not sole basis of state, 272-74; philosophy of church, 29r ff; thought, recent changes in, 350-52.

Economics, science of means, 373 .

Emotional realization of social ideals, Io6.

Emperor, Roman, position of, 58, 59 .

Empire: establishment of Roman, 58; ethical end of, 60; Holy Roman, meaning of, 92, 95, 275, 283.

Ends, function of, 94.

English: feudalism, I 28 ff.; towns, 214-I7; merchant gilds, 216, 22 I23; monarchy, 277; commerce in
Middle Ages, 259; democratic movement, 314; industrial revolution, 339 .

Ethical: problem of Middle Ages, 94, 95; philosophy and art-consciousness, 48; evolution depends on economic, 102; ideals disregarded, 273 , 274 ; ideals, present need of, $36 \mathrm{I}-64$.

Ethics, science of ends, 373.

Europe: unity of, 68; begins with ideal of social order, $9 \mathrm{I}$.

Factory system, beginning of, 33I.

Facts, meaning of, $365-69$.

Fairs, 204, 205.

Familia, Roman, I 10.

Feudalism: Italian, I 23 ff.; English, I 28 ff.; general, I 54 ff.; recognized by Otho, I73; causes of, r 74-76.

Feudal system: and agriculture, I08; and food-supply, I66; uniformity of, I22; persistence of, 235; and the towns, 234 .

Flanders: and England, 260-62; woolen industry of, 196, 248, 260-62; merchant gilds of, 223,224 .

Florence, $245 \mathrm{ff}$.

Florentine: gilds, 245-47; commune, 245; woolen industry, 248, 249 .

Frankish: conquest, I $55 \mathrm{ff}$;; freemen, I60-62; counts, I69, I7I, 173 .

Free mark theory, $137 \mathrm{ff}$.

Freemen: German, I 7 , I1 8, 122, 138; Frankish, 160-62; Saxon, 142, 143; must control product of industry, $354 \mathrm{ff}$.

French monarchy: rise of, 276,277 ; and the towns, 2II-13; and merchant gilds, 223, 224 .

Generalization, Greek and mediæval compared, 97-99.

Genetic explanation, importance of, $376,379$.

German: early social life, $83-85$; private ownership, 85 ; agriculture, 85 , I30, I48 ff.; village, I I 7 ; slaves, I 18 20; towns, 213; unification delayed, 280-83.

Gild: merchant, $216,22 \mathrm{I}-24$; nature of, $217,218,221$; craft, $226 \mathrm{ff}$; capitalistic, 230-32; control of technique, 231-35; and manor compared, 234, 
235; and individual, 235, 236; artisans freed from, 311 .

Gross on gild merchant, $226 \mathrm{ff}$.

Hamburg and its Hanse in England, 265.

Hansa, Teutonic, $263 \mathrm{ff}$.

Hanse of London, 231, 263.

Heaven, development of idea of, 76 .

Hobbes, social philosophy of, $30 \mathrm{rff}$.

Household estates of Germans, Ir 8.

Hypothesis, working, 365-67.

Ideal community and ideal individual, $65,66$.

Ideals: Christian, 74; and social decay, 9I; importance of mediæval, 9I; held by church, 92 ; give unity to mediæval society, 93, 94; emphasized by Charlemagne, 95 ; present social, $359 \mathrm{ff}$.

Idle classes, $35^{8}$.

Immunity, $\mathrm{x} 68-72$.

Individual: prophets recognize, I5, I6; in teaching of Jesus, 21 ; disregarded by Roman Empire, 60; outcome of Hebrew development, 65, 66; conditions of definition of, $65,66,69$; of Augustine, $79-8 \mathrm{r}$; and consciousness of social values, 106, 107, 235; and control of product of industry, 236; of Hobbes, 30r; emphasized by democratic movement, 3 IO; of Enlightenment, $313,315,318$; modern, 313, 319; and consumption, 353; a social outcome, 376 .

Industrial peace, $342,343,347,348$.

Industrial Revolution: and mechanical inventions, $325,33 \mathrm{I}$; and division of labor, 325 ; and thought, 362 .

Industrialism, $324 \mathrm{ff}$.

Industry: influence on, of Egypt, $26 \mathrm{ff}$.; Greek idealized, 36; control of, in Egypt, $26 \mathrm{ff}$;; survival of Roman, I03; mediæval, freed from technical control, r04; in the towns, 202.

Institutional framework contributed by Rome, 64 .

Inventions, mechanical, 329-3I.

Invasions, influence of, on church, 79, 88.
Irrigation, Egyptian, and social organization, 28.

Isaiah, 16.

Israel: contribution of, $2 \mathrm{ff}$.; monotheism of, 2-4; monarchy of, $6 \mathrm{ff}$.; and world-empires, $13 \mathrm{ff}$.

Italian: merchant associations, 224; commercial cities, $239 \mathrm{ff}$; decay of commercial cities, $248 \mathrm{ff}$; leagues impossible, 252, 256.

Jeremiah, 16 .

Jerusalem, New, conception of, 76 .

Jesus, ethical teaching of, 20, $21,69,70$.

Jewish church, beginning of, 16, 19 .

Jus civile, 62.

Jus gentium, 62, 63 .

Keynes on social history, 391 .

Labor rents, commutation of, 147, 197, $219,220$.

Laborers: Egyptian, 28 ff.; Athenian, 36, 40-42; Roman, I16; mediæval, freedom of, within calling, ro5; unions of, $340 \mathrm{ff}$.; efficiency of, 344, 345; share of values, 348 ; modern, control product, 354,355 ; standards of living of modern, 355 .

Land-holding: Greek, 23, 24; by German households, II 8 ; by chieftains, I21; by counts, 127 .

Law: of nature, 62, 307; Roman, 6r ff.; of nations, $305 \mathrm{ff}$.

Leagues, commercial, $26_{3} \mathrm{ff}$.

Locke, John, 314.

London, Hanse of, 263.

Luxuries, nature of trade in, 248,250 , 252, 253; become necessaries, 258.

Mackenzie: on social organism, 374, 375; on social history, 392,393 .

Magic: use of, by church, 89,99 ; , failure of, 102, 297.

Manager differentiated from capitalist, 334 .

Manorial courts, 152, 153, 168.

Manors: number in Domesday 137; indivisibility of, 137 ; freemen on, I38; antiquity of Saxon, 150; economic independence of, $163,164,184$; productivity of, 153,154 ; as political units, 172 ; regulation of, 174,175 ; 
ecclesiastical, I76-79; mediate between individual and society, 182 ; manufactures of, I95; do not become towns, 203.

Maritime regulations, 240.

Mark theory, 137 ff.; 370 .

Markets, mediæval, 204, 205.

Mathews, Shailer, on social philosophy of Jesus, 75, note.

Means: directed by ends, 94 ; church attempts to organize, 94 ; nature of, required by Europe, I02.

Mediæval: period, limits of, 68, ro6, 286; wars, 93; and modern thought compared, 93; and Greek generalizations compared, 97-99; gilds, ro5.

Mediators: required by mediæval society, 90; ascetics and priests as, 90 , 91; manors as, 182 .

Mercantilism, 278, 279, 283, 284 .

Merchants: in Dark Ages, r99, 202; and commercial revival, 199; and feudal lords, 207-9; and royal power, 210-13; as rulers, 21 7, 25I, 252, 273; associations of, $220-24,246$; relations of, to craftsmen, 228, 231, 247 .

Merovingian: absolutism, $155-57,169$; counts, I 58, I68, I69; commerce, 164 .

Messianic idea, 20.

Method: problem of, 300 ; of social history, 389-93.

Middle Ages, ideals and problem of, $9 r$.

Military: organization of Germans, II8; organization and slavery, I 20; leader becomes ruler; organization of Saxons, 134 .

Modern: period, beginning of, 286; philosophy, $298 \mathrm{ff}$.

Monarchy: French, 276, 277; English, 277.

Monasteries and manual labor, $\mathbf{I 7}$.

Money and commerce 147 .

Monolatry, Israelitish, 4, 5, 6.

Monotheism: Hebrew and Greek compared, 2, 50; economic conditions of, 3 ; and monarchical institutions, 6-9.

Montesquieu, 3 I4.

Motives, reorganization of, 70 .

National state: impossible in Italy, 256, 257; development of, $274 \mathrm{ff}$.
Nations, law of, $305 \mathrm{ff}$.

Naturalization among Semites, 6, 7 .

Nature: law of, 62; interest in, 299.

Necessaries, importance of, in production, 353,354 .

Netherlands, 279, 280.

Nominalism, roo, ror.

Norman conquest, 129, 145-48.

Novgorod and the Hansa, 266.

Occam, William of, ror.

Organic nature of modern society, 358$6 r$.

Organism: society an, 373; social, meaning of, 374; Mackenzie and Dewey on, 374,375 .

Oriental trade, 240, 253.

Otho and Charlemagne compared, 95-97.

Particular and universal, 99, 288, 300.

Pauline Christianity, 71, 72.

Peculium of Roman slave, III, Ir2, II5.

Pecuniary emulation, 236.

Philosopher in Plato's republic, 42, 47.

Philosophy: Greek, 37 ff.; modern, $298 \mathrm{ff}$.; political, of Renaissance, $302 \mathrm{ff}$; social, $367,368,397$; and social life, $395-97$.

Phœnicians: influence of, on Greeks, $26 \mathrm{ff}$.; as intermediaries, 33-35.

Pigeonneau on beginnings of commerce, r94.

Pirenne on origin of towns, 201, 202.

Plato's state, 42, 47-49.

Political: history, 384,385 ; structure and economic interdependence, 27r; organization as end of statesmen, 273; philosophy of Renaissance, $302 \mathrm{ff}$.

Popular sovereignty, $3^{1} 5$.

Portuguese expansion, 278.

Prices: and consumption, 347 ; and real wages, 349 ; and production of necessaries, 354,356 ; mediæval theory of, 292, 293.

Priesthood, meaning of mediæval, 76, 77.

Priests, Hebrew: relation to prophets, 
ro; a ruling class, 15 ; ethical conceptions of, 15, 16; in exile, 17, 18.

Primitive: social life, 65; institutions, interest in, 370.

Product of industry, control of, 40-42, 354, 355 .

Production, social character of modern, $336,338,35^{\circ}$.

Profits: of the rich, 337,338 ; a differential, 343, 344; failure of attacks on, 344,345 .

Prophets, Hebrew: relation to priests, ro, 14; and the progressive party, 10; and individual righteousness, 15,16 ; failure of, 17,18 .

Public opinion and democratic government, 323 .

Realism, 99, 100, 288, 289.

Reformation, religious, $288 \mathrm{ff}$.

Revolution: theory of, 315, 316; Industrial, $325 \mathrm{ff}$.

Rhodians, law of, $305,306$.

Rich: expenditures of, 356 ; idle, $35^{8}$.

Rogers, Thorold, on economic history, 389.

Roman: colonial system, 57,58 ; empire, 58; state and Platonic ideal, 59; law, 6 I ff.; system and the organization of Europe, 66, 67; influence on barbarians, 86,87 , I I5; agriculture, IIO; slaves, III; freedmen, III, II 2 ; colons, I12-I5; influence on British agriculture, $130,13 \mathrm{r}$.

Romanticism, 298, 299.

Roscellinus, roo.

Rousseau, 315, 316.

Royal domains: administration of, 159 ; influence of, 179,180 .

Sacrifice: early, 9; expiative, 14, 15. Saint, character of, 76 .

Seebohm on tribal settlements, II $8 \mathrm{ff}$.

Semitic tribal life, $3 \mathrm{ff}$.

Serfdom, 120-26, 1 33-36, 149, I 5 I, 152, I6r, 162, 218, 219 .

Signory, Italian, 247, 254-56.

Slavery: meaning of, 28, 29; Greek, 23, 39; Roman agricultural, Iro. German, III, II3; impossible in Middle Ages, I05; disappearance of, I1 8, I6r, I62.
Small on statics and dynamics, $381,3^{8} 3$.

Social consciousness, $370,37 \mathrm{r}, 39 \mathrm{r}$.

Social history, methods of, 387,388 .

Social ideals, 359 ff., 93.

Social organism, statement of, 364,374 , 375 .

Sociology, 367-72, 383, 384, 397 .

Spain, unification of, $278,279$.

Spencer, Herbert, 365, 367, 386.

Standard of living and modern production, $355,35^{8}$.

Standards, Greek conception of, 46-49.

State: meaning of, 373 ; Platonic, 4247; national, 274 ff.; neither means nor end, 273, 274, 284; Aquinas on, 289; Dante on, 290; Hobbes on, 303 ; Rousseau on, $315,316$.

Steelyard, 264-66.

Stoic philosophy, influence on Roman law, 62,63 .

Strikes, 346 .

Supernatural, belief in, and social dislocations, 89 .

Surplus wealth, use of, 336 .

Tacitus on German life, 84, 85, 118 .

Technique: abstraction of, 26 ; control of, in Egypt, 28, 3I, 32; freeing of, in Greece, 36; control of, in Greece, 40, $4 \mathrm{I}$; freedom of, in Middle Ages, 104; freedom of, and legal freedom, rI9; becomes common property, 354 .

Teutonic: agriculture, I $17 \mathrm{ff}$; Hansa, $263 \mathrm{ff}$.

Textiles, importance of, in commerce, I96, 200.

Theology and Greek philosophy, 72, 73 .

Thought, histories of, $385,394,395$.

Towns, rise of, 20 I ff.

Toynbee on employer and employee, 343 .

Trade unions, 343-49.

Tribal organizations and the invasions, 120,121 .

Tribes and gods, 4 .

Turkish conquests, 253 .

Unification of Europe: and agriculture, 184,185 ; and national states $283-85$. 


\section{DEVELOPMENT OF WESTERN CIVILIZATION}

Union labor: and efficiency, 344, 345; and unorganized labor, 345 ; and employers, 346,347 .

Unity of society: mediæval, in ideals, 91; modern, in activities, 287.

Universals: Greek and mediæval compared, 97-99; and particulars, 99; reconciliation by magic, 99 .

Urban constitutions, $207 \mathrm{ff}$.

Vassalage: in Italy, 124-26; in England, I36, 145-48; European, 172 ff. Venice, 24I ff.
Vinogradoff on Norman conquest, 145, 148-5I.

War leader becomes chief, 85 .

Ward, L. F.: on statics and dynamics, 380,381 ; on history, 386 .

Western Europe and religious theories, 8I.

Wilson, Woodrow, on expansion of Rome, 57.

World-history, beginning of, $\mathrm{x}_{3} \mathrm{ff}$.

Wundt, on statics and dynamics, 383 384 . 
$$
\text { , }
$$ 


civilization

\section{PLEASE DO NOT REMOVE CARDS OR SLIPS FROM THIS POCKET}

\section{UNIVERSITY OF TORONTO LIBRARY}


